\title{
Nickel-Catalyzed Secondary Alkylations and Fluoroalkylations via
}

\section{C-H Activation}

\author{
Dissertation \\ zur Erlangung des mathematisch-naturwissenschaftlichen Doktorgrades \\ “Doctor rerum naturalium” \\ der Georg August Universität Göttingen

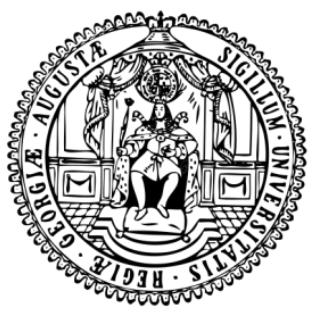 \\ im Promotionsprogramm der \\ Georg-August University School of Science (GAUSS) \\ vorgelegt von \\ Sebastian Lackner \\ aus Schwandorf, Deutschland
}

Göttingen, 2016 


\section{Erklärung}

Ich versichere, dass ich die vorliegende Dissertation in der Zeit von

Januar 2012 bis Juni 2016 am

Institut für Organische und Biomolekulare Chemie

Der Georg-August-Universität zu Göttingen

Auf Anregung und unter Anleitung von

Herrn Prof. Dr. Lutz Ackermann

Selbstständig durchgeführt und keine anderen als die angegebenen

Hilfsmittel und Quellen verwendet habe.

Göttingen, den 30.05.2016

Sebastian Lackner

1. Gutachter: Prof. Dr. Lutz Ackermann

2. Gutachter: Prof. Dr. Konrad Koszinowski

Tag der mündlichen Prüfung: 29.06.2016 


\section{Mitglieder des Betreuungsauschusses:}

Prof. Dr. Lutz Ackermann, Institut für Organische und Biomolekulare Chemie

Prof. Dr. Konrad Koszinowski, Institut für Organische und Biomolekulare Chemie

\section{Mitglieder der Prüfungskommission:}

Prof. Dr. Lutz Ackermann, Institut für Organische und Biomolekulare Chemie

Prof. Dr. Konrad Koszinowski, Institut für Organische und Biomolekulare Chemie

Weitere Mitglieder der Prüfungskommission:

Prof. Dr. Claudia Höbartner, Institut für Organische und Biomolekulare Chemie

Prof. Dr. Sven Schneider, Institut für Anorganische Chemie

Dr. Shoubhik Das, Institut für Organische und Biomolekulare Chemie

Dr. Franziska Thomas, Institut für Organische und Biomolekulare Chemie 
Für meine Eltern 
Da steh ich nun, ich armer Tor!

Und bin so klug als wie zuvor.

- Faust I, Vers 354ff

Johann Wolfgang von Goethe 


\section{Table of Contents}

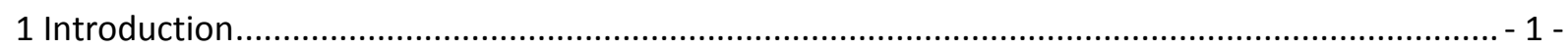

1.1 Alkyl Groups in Natural Products and Pharmaceuticals ............................................................. - 1 -

1.2 Alkylations through traditional Cross-Coupling Reactions..................................................... - 3 -

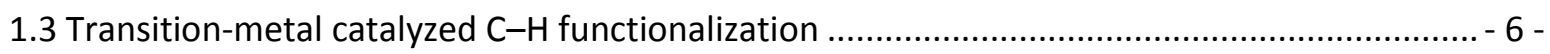

1.4 Nickel-catalyzed C-H functionalization .............................................................................. 13 -

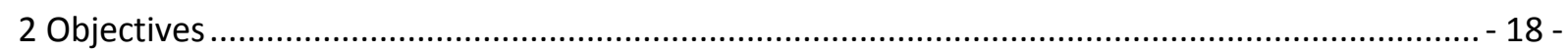

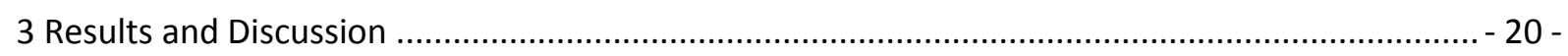

3.1 Direct C-H secondary Alkylation under Bidentate Assistance ............................................ 20 -

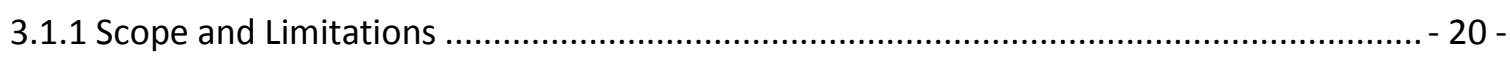

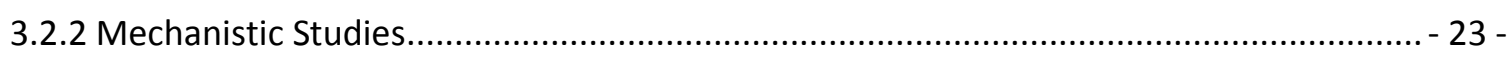

3.2 Direct C-H Trifluoroethylation under Bidentate Assistance .................................................... - 25 -

3.3 Direct Secondary C-H Alkylation of N-Pyrimidyl-Anilines .................................................... 26 -

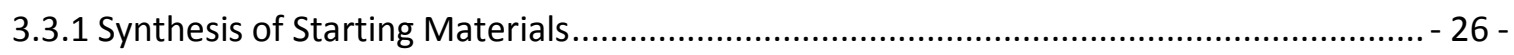

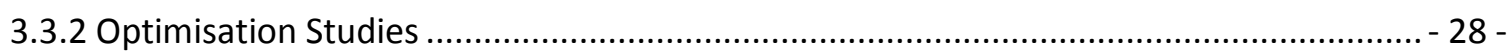

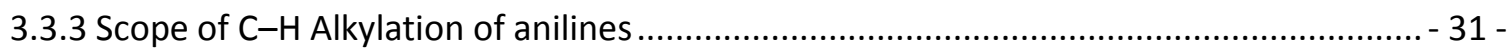

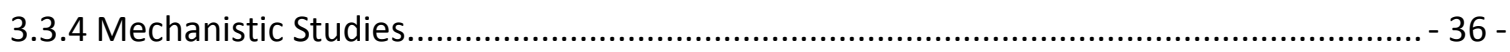

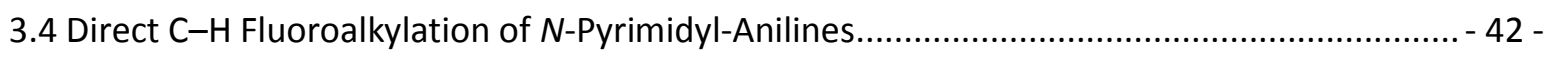

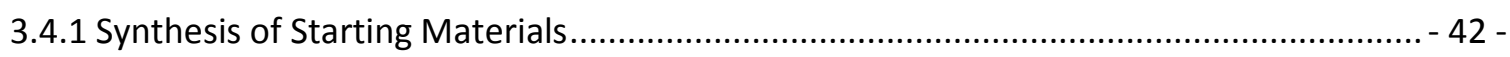

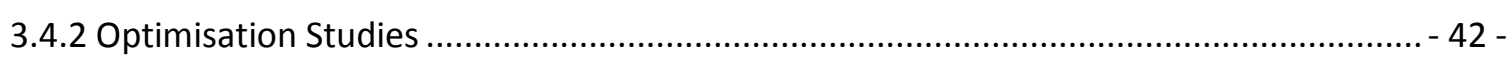

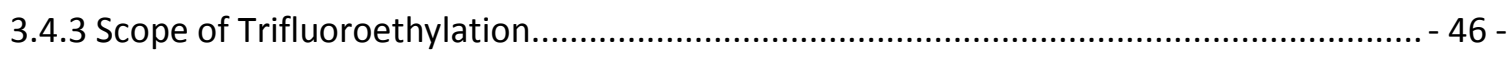

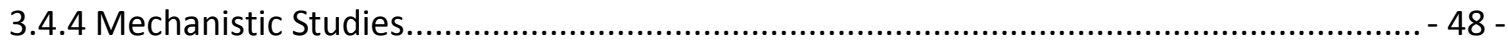

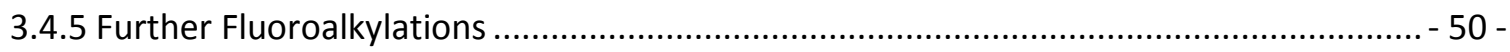

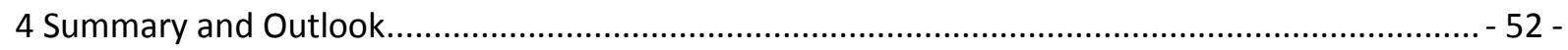

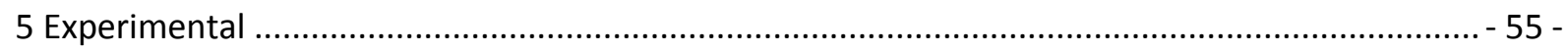

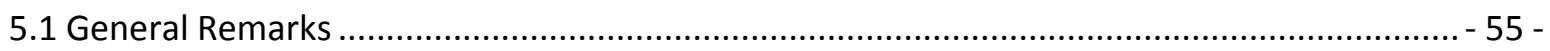

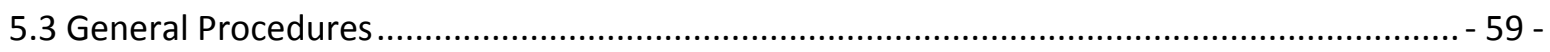

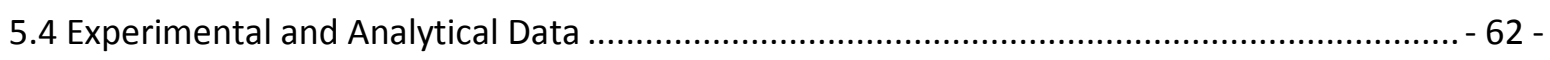

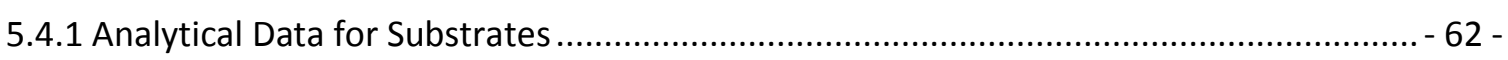

5.4.2 Analytical Data for C-H Secondary Alkylation of Benzamides 59 ..................................... 69 -

5.4.3 Analytical Data for C-H Trifluoroethylation of benzamides 59..................................... 80 -

5.4.4 Analytical Data for C-H Secondary Alkylation of $\mathrm{N}$-(2-Pyrimidyl)anilines 69................... 83 -

5.4.5 Analytical Data for C-H Fluoroalkylation of $\mathrm{N}$-(2-Pyrimidyl)anilines $69 . \ldots \ldots \ldots \ldots \ldots \ldots \ldots . . . . . . . . . . . . .112$ - 
6 List of Abbreviations

$127-$

7 Acknowledgements .

$129-$

8 Curriculum Vitae 


\section{Introduction}

\subsection{Alkyl Groups in Natural Products and Pharmaceuticals}

Compounds bearing alkyl groups have received significant attention in various fields of organic chemistry. This is due to their abundance in natural compounds, such as steroids, alkaloids, polyketides, lipids, as well as in the side-chain of peptides (Scheme 1). ${ }^{1}$ Estradiol (1), for example, is not only relevant for regulation of the ovarian cycle, but is also, along with other estrogenes, linked to breast and ovarian cancer growth. Erythromycin (2) and derivatives thereof have shown anti-biotic activity. Vitamin E (4) inactivates reactive oxygen species, in order to avoid cell damages, such as oxidation of unsaturated membrane lipids.

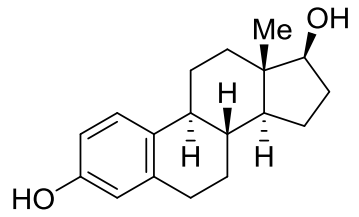

1

Estradiol

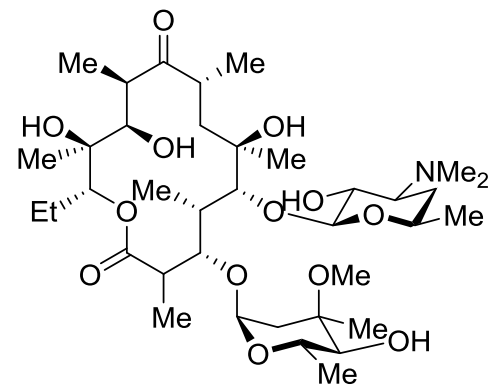

2

Erythromycin<smiles>C[C@]12CC[C@H](CO)[C@@H](O)C[C@H]1CC[C@@H]1c3ccoc3CC[C@]12C</smiles>

3

Cafestol<smiles>Cc1c(C)c2c(c(C)c1O)CC[C@](C)(CCC[C@H](C)CCC[C@H](C)CCCC(C)C)O2</smiles>

4

Vitamin E ( $\alpha$-tocopherol form)<smiles>COc1cc(CNC(=O)CCCC/C=C/C(C)C)ccc1O</smiles>

5

Capsaicin

Scheme 1: Selection of natural compounds containing aliphatic groups.

Therefore, aliphatic chains and cycles with various substitution patterns and functional groups can be commonly found in a wide range of top-selling drugs and pharmaceuticals (Scheme 2). ${ }^{2}$

\footnotetext{
${ }^{1}$ (a) Berg, J. M.; Tymoczko, J. L.; Stryer, L. Biochemistry, 7th int. ed., E. H. Freeman and Company, New York, 2012. (b) Leeper, F. J.; Vederas, J. C. Biosynthesis: Polyketides and Vitamins, Springer Verlag, Berlin, 2000. (c) Kibwage, I. O.; Hoogmartens, J.; Roets, E.; Vanderhaeghe, H.; Verbist, L.; Dubost, M.; Pascal, C.; Petitjean, P.; Levol, G. Antimicrob Agents Chemother. 1985, 28, 630-633. (d) Kittakoop, P.; Mahidol, C.; Ruchirawat, S. Curr Top. Med. Chem. 14, 2, 239-252. (e) Ricketts M. L.; Boekschoten M. V.; Kreeft A. J.; Hooiveld G. J.; Moen C. J.; Müller M.; Frants R. R.; Kasanmoentalib S.; Post S. M.; Princen H. M.; Porter J. G.; Katan M. B.; Hofker M. H.; Moore D. D. Mol. Endocrin. 2007, 21 , 1603-1616.

${ }^{2}$ (a) McGrath, N. A.; Brichacek, M.; Njardarson, J. T. J. Chem. Ed. 2010, 87, 1348-1349. (b) Aggarwal, R. K.; Showkathali, R. Expert Opin. Pharmacother. 2013, 14, 1-13. (c) Sanford, M. Drugs 2014, 74, 1411-1433. (d) Chen, M.-J.; Cheng, C.-Y.; Chen, Y.-C.; Chou, C.-K.; Hsu, W.-M. J. Ocul. Pharmacol. Ther. 2006, 22, 188-193.
} 
<smiles>COS(=O)(=O)c1nc(-c2ccc(F)cc2)c(/C=C/C(O)C[C@H](O)CC(=O)O)c(C(C)C)n1</smiles>

6

Rosuvastatin anti-LDL-C<smiles>CCCCCCCc1ccc(CCC(N)(CO)CO)cc1</smiles>

7

Fingolimod anti-RRMS

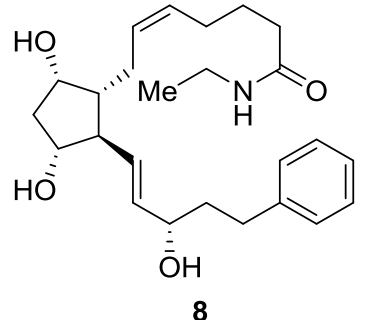

Bimatoprost anti-glaucoma

Scheme 2: Selection of marketed drugs containing aliphatic moieties.

One particularly noteworthy effect of alkyl groups within medicinal chemistry is the so-called "magic methyl" effect. . Usually, when a methyl group is added to a compound, an increase of biological potency of up to tenfold can be expected. This can usually be attributed to hydrophobic and desolvation effects. However, in some cases, the potency increase can be as high as two orders of magnitude, which is then labeled as the aforementioned "magic methyl" effect (Scheme 3). Such an extreme effect usually occurs, when the introduction of the methyl group causes the unbound compound to assume a shape complementary to the bound form in the target's active site. Thus, the conformational change to achieve binding in the active site is minimised.

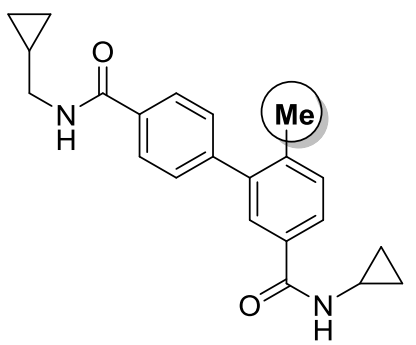

9

208-fold boost p38 $\alpha$ MAP38 kinase inhibitor

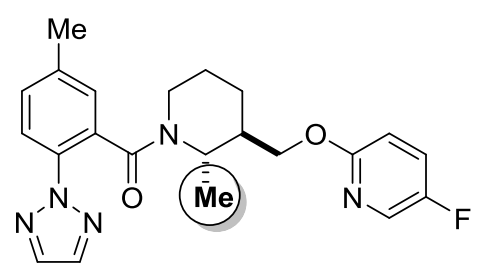

10

480-fold boost Orexin-1/-2 antagonist<smiles>Cc1cc(-c2cccc(NCc3ccccc3)c2)cc(C)c1C(=O)NC(C)C(=O)O</smiles>

11

2135-fold boost $\mathrm{S}_{1} \mathrm{P}_{1}$ antagonist

Scheme 3: Boost in potency by introduction of a methyl group.

In addition to this effect there is also a particular interest within pharmaceutical research for developing fluorinated analogues of bioactive compounds. Such compounds may show significantly altered chemical reactivity, but it has also been shown that the introduction of fluorine atoms into biologically active molecules has a profound and complex impact on their metabolic behaviour. Special interest has been given in medicinal chemistry to the introduction of trifluoromethyl groups. However, fluorinated, marketed drugs are still rather

\footnotetext{
${ }^{3}$ Schönherr, H.; Cernak, T. Angew. Chem. Int. Ed. 2013, 52, 12256-12267, and references cited therein.
} 
scarce, as suitable methodologies for the introduction of fluorinated groups are still being developed. ${ }^{4}$ A selection of fluorine-containing, marketed drugs is shown in Scheme $4 .{ }^{5}$<smiles>Cc1oncc1C(=O)Nc1ccc(C(F)(F)F)cc1</smiles>

12

leflunomide anti-rheumatic<smiles>O=C1Nc2ccc(Cl)cc2[C@@](C#CC2CC2)(C(F)(F)F)O1</smiles>

13

efavirenz anti-retroviral<smiles>N[C@@H](CC(=O)N1CCn2c(nnc2C(F)(F)F)C1)Cc1cc(F)c(F)cc1F</smiles>

14

sitagliptin anti-diabetic<smiles>Cc1c(OCC(F)(F)F)ccnc1CS(=O)c1nc2ccccc2[nH]1</smiles>

16

dexlansoprazole proton pump inhibitor<smiles>O=C(Nc1c(Cl)cncc1Cl)c1ccc(OC(F)F)c(OCC2CC2)c1</smiles>

17

roflumilast anti-inflammatory<smiles>NC(=O)c1cn(Cc2c(F)cccc2F)nn1</smiles>

18

rufinamide anti-convulsant<smiles>C[C@H](O[C@H]1OCCN(Cc2nc(=O)[nH][nH]2)[C@H]1c1ccc(F)cc1)c1cc(C(F)(F)F)cc(C(F)(F)F)c1</smiles>

15

aprepitant anti-emetic

Scheme 4: Selection of fluorine-containing, marketed drugs.

\subsection{Alkylations through traditional Cross-Coupling Reactions}

As mentioned in the previous chapter, $\mathrm{C}-\mathrm{C}$ bond forming reactions for the synthesis of alkylated scaffolds have always been of highest importance within organic synthesis. In the last few decades focus has been particularly on transition metal-catalyzed cross-coupling reactions. Early examples for cross-coupling reactions include the Glaser coupling ${ }^{6}$ and the Ullman coupling ${ }^{7}$ (Scheme 5). These reactions, however, apart from being limited to aryl and

\footnotetext{
${ }^{4}$ Zhu, W.; Wang, J.; Wang, S.; Gu, Z.; Acena, J. L.; Izawa, K.; Liu, H.; Soloshonok, V. A. J. Fluorine Chem. 2014, 167, 37-54.

5 (a) Sanders, S.; Harsidangkul, V. Am. J. Med. Sci. 2002, 323, 190-193. (b) Cespedes, M. S.; Aberg, J. A. Drug Saf. 2006, 29, 865-874. (c) Gadsby, R. Clin. Med. Ther. 2009, 1, 53-62. (d) Hargreaves, R.; Ferreira, J. C. A.; Hughes, D.; Brands, J.; Hale, J.; Mattson, B.; Mills, S. Ann. N. Y. Acad. Sci. 2011, 1222, 40-48. (e) Behm, B. W.; Peura, D. A. Expert Rev. Gastroenterol. Hepatol. 2011, 5, 439-445. (f) Field, S. K. Expert Opin. Investig. Drugs 2008, 17, 811818. (g) Hakimian, S.; Cheng-Hakimian, A.; Anderson, G. D.; Miller, J. W. Expert Opin. Pharmacother. 2007, 8, 1931-1940.

${ }^{6}$ Glaser, C. Justus Liebigs Ann. Chem. 1870, 154, 137-171.

${ }^{7}$ (a) Ullman, F.; Bielecki, J. Ber. Dtsch. Chem. Ges. 1901, 34, 2174-2185.; A review: (b) Hassan, J.; Sevignon, M.; Gozzi, C.; Schulz, E.; Lemaire, M. Chem. Rev. 2002, 102, 1359-1469.
} 
alkyne moieties, could originally only proceed by utilisation of stoichiometric amounts of transition metals.

(a) Glaser coupling

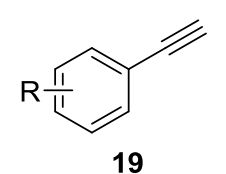

19

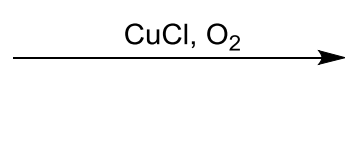

(b) Ullman coupling

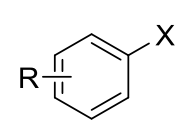

$X=I(21), \operatorname{Br}(22)$

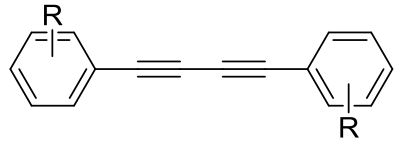

20

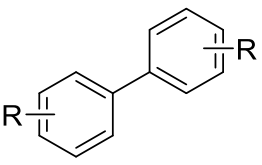

23

Scheme 5: General reaction equation for (a) the Glaser coupling and (b) the Ullman coupling.

The first step towards catalyzed reactions was first achieved by Job in the early 1920 s. $^{8} \mathrm{He}$ found that a solution of phenyl magnesium bromide does not react with ethylene gas, unless anhydrous nickel dichloride is introduced. Furthermore, he showed that the uptake of ethylene gas in the reaction is solely dependent on the amount of Grignard reagent and not on the amount of nickel dichloride. Although this yielded a mixture of ethylbenzene, styrene, biphenyl and other hydrocarbons, Job thus proved that nickel dichloride could be used for such reactions in catalytic quantities. Two decades later, Kharasch conducted investigations on the cobalt-catalyzed $\mathrm{C}-\mathrm{C}$ bond formation of aryl Grignard reagents with both aryl bromides and vinyl bromides to yield the corresponding biphenyls and styrenes. ${ }^{9}$ Significant advancements in this type of reaction were achieved in the 1970s with the extension of cross-coupling reactions towards the use of palladium- and nickel-catalysis. The most commonly employed catalytic cross-coupling reactions include the Kumada-Corriu coupling, Negishi coupling, Suzuki-Miyaura coupling, Migita-Kosugi-Stille coupling, Hiyama coupling, Mizoroki-Heck reaction and Sonogashira-Hagihara coupling (Scheme 6). ${ }^{10}$ The importance of these advancements were significant enough so that in 2010 professors Akira Suzuki, Ei-ichi Negishi and Richard Frederick Heck were honoured with the Nobel prize in Chemistry for their contributions to the field of palladium-catalyzed cross-coupling chemistry. ${ }^{11}$

\footnotetext{
${ }^{8}$ Job, A.; Reich, R. C. R. Hebd. Seances Acad. Sci. 1924, 179, 330-332.

${ }^{9}$ (a) Kharasch, M. S.; Fields, E. K. J. Am. Chem. Soc. 1941, 63, 2316-2320. (b) Kharasch, M. S.; Fuchs, C. F. J. Am. Chem. Soc. 1943, 65, 504-507.

${ }^{10}$ Selected review: Johansson Seechurn, C. C. C.; Kitching, M. O.; Colacot, T. J.; Snieckus, V. Angew. Chem. Int. Ed. 2012, 51, 5062-5085.

${ }^{11}$ http://www.nobelprize.org/nobel_prizes/chemistry/laureates/2010 (accessed December 6th, 2015).
} 
(a)

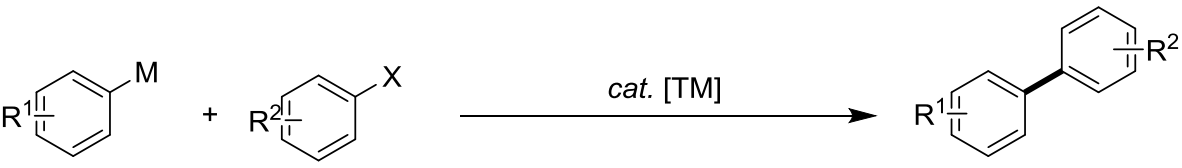

$M=\operatorname{MgX} \quad$ (24) (Kumada-Corriu) $X=I \quad$ (21)

ZnX (25) (Negishi) $\operatorname{Br}(22)$

$\mathrm{SnX}_{3}$ (26) (Stille) $\mathrm{Cl}(29)$

$\mathrm{BOR}_{2}$ (27) (Suzuki-Miyaura)

$\mathrm{SiOR}_{3}(\mathbf{2 8})$ (Hiyama)

(b) Mizoroki-Heck reaction<smiles>[R]C=CC[NH2+]</smiles>

$21 / 22 / 29$

30

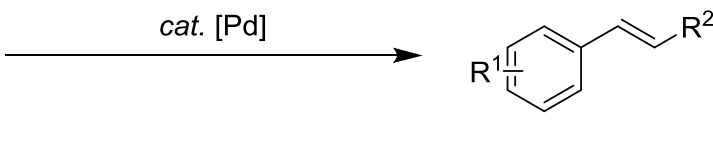

31

(c) Sonogashira-Hagihara coupling<smiles>[X]c1cc[R1]cc1</smiles>

$21 / 22 / 29$

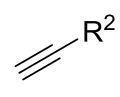

19

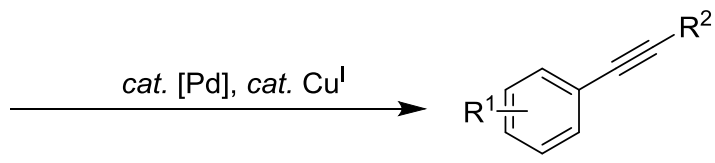

32

Scheme 6: General equations for transition metal catalysed cross couplings reactions.

The widely accepted catalytic cycle for most of cross-coupling reactions consist of an oxidative addition of the organic halide to the catalyst, transmetalation with an organometallic reagent, followed by a reductive elimination (Scheme 7a). In the case of the Mizoroki-Heck reaction, the oxidative addition is followed by a syn-addition to the olefin, syn- $\beta$-hydride elimination and reductive elimination (Scheme $7 \mathrm{~b}){ }^{12}$

(a)

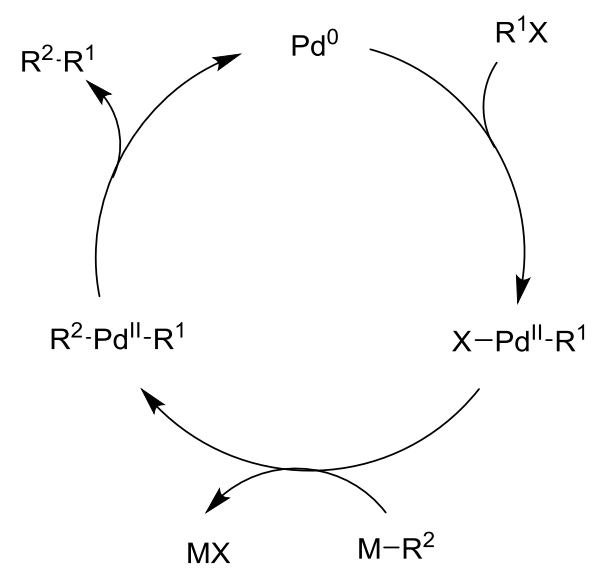

(b)

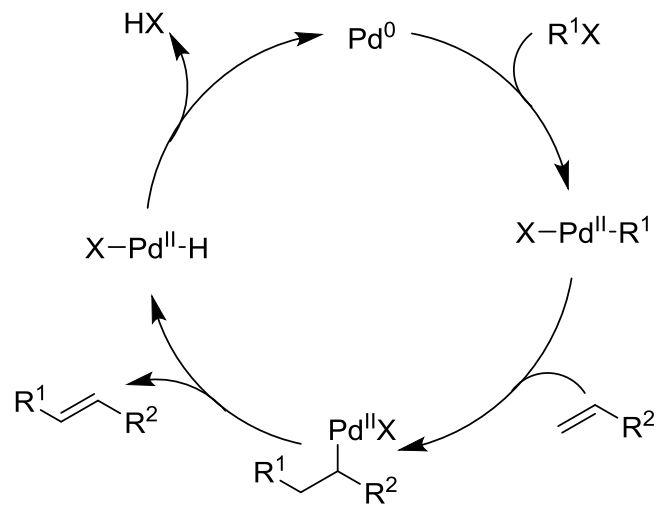

Scheme 7: Catalytic cycles for (a) cross coupling and (b) Heck reactions.

${ }^{12}$ Kürti, L.; Czakó, B. Strategic Applications of Named Reactions in Organic Synthesis, Elsevier Inc., London, 2005. 
Initially, these transformations were limited to the coupling of $\mathrm{sp}^{2}$ - or sp-hybridized-carbon centres, with the exception of the nickel-catalysed Kumada-Corriu coupling. The corresponding alkylation coupling reactions proved more challenging due to the tendency of the alkylated intermediates to undergo $\beta$-hydride elimination, thus forming undesired olefinic side products. ${ }^{13}$ In subsequent years, many new protocols for alkylation coupling reactions have been developed. ${ }^{14}$ These cross-coupling reactions have found numerous applications in total synthesis, ${ }^{15}$ as well as in industrial settings. ${ }^{16}$

\subsection{Transition-metal catalyzed C-H functionalization}

Despite the enormous advances achieved by the previously discussed cross-coupling reactions, limitations still need to be addressed. For traditional cross-coupling reactions organic halides, as well as a organometallic reagents, are required. Therefore prefunctionalisation of substrates was necessary. These pre-functionalisation steps, along with the cross-coupling itself, are each accompanied with the generation of stoichiometric amounts of by-products and metal waste.

Due to spiralling costs and dwindling resources sustainability has become a major focus in both industry and society in general. ${ }^{17}$ Nonetheless, the goal of more efficient, atomeconomical strategies were already pointed out in the early 1990 s by Barry Trost. ${ }^{18}$ Among possible solutions were the development of $\mathrm{C}-\mathrm{H}$ functionalisation reactions via organometallic $\mathrm{C}-\mathrm{H}$ bond activation. These type of reactions can be divided into three categories (Scheme 8). ${ }^{19}$

\footnotetext{
${ }^{13}$ Ackermann, L. Chem. Commun. 2010, 46, 4866-4877.

${ }^{14}$ (a) Tollefson, E. J.; Hanna, L. E.; Jarvo, E. R. Acc. Chem. Res. 2015, 48, 2344-235. (b) Cherney, A. H.; Kadunce, N. T.; Reisman, S. E. Chem. Rev. 2015, 115, 9587-9652. (c) Netherton, M. R.; Fu, G. C. Adv. Synth. Catal. 2004, 346, 1525-1532.

${ }^{15}$ (a) Hong, A. Y.; Stoltz, B. M. Eur. J. Org. Chem. 2013, 2745-2759. (b) Majumdar, K. C.; Sinha, B. Synthesis 2013, 45, 1271-1299. (c) Sasaki, M. Bull. Chem. Soc. Jpn. 2007, 80, 856-871.

${ }^{16}$ (a) Xu, S.; Kim, E. H.; Wei, A.; Negishi, E. Sci. Technol. Adv. Mater. 2014, 15, 044201. (b) Corbet, J.-P.; Mignani, G. Chem. Rev. 2006, 106, 2651-2710. (c) Dumrath, A.; Lübbe, C.;Beller, M. Palladium-Catalyzed Cross-Coupling Reactions - Industrial Applications, in Palladium-Catalyzed Coupling Reactions: Practical Aspects and Future Developments, Wiley-VCH Verlag GmbH \& Co. KGaA, Weinheim, 2013. (d) Torborg, C.; Beller, M. Adv. Synth. Catal. 2009, 351, 3027-3043.

${ }^{17}$ Sheldon, R. A. Chem. Soc. Rev. 2012, 41, 1437-1451.

${ }^{18}$ Trost, B. M. Science 1991, 254, 1471-1477.

${ }^{19}$ Ackermann, L; Vicente, R.; Kapdi, A. R. Angew. Chem. Int. Ed. 2009, 48, 9792-9826.
} 
(a)

$\mathrm{C}-\mathrm{H}$

activation with electrophiles

(b)

$$
\mathrm{C}-\mathrm{H}
$$

activation with nucleophiles

(c) cross-dehydrogenative $\mathrm{C}-\mathrm{H}$ activation
$\mathrm{R}^{1}-\mathrm{H}+\mathrm{X}-\mathrm{R}^{2}$

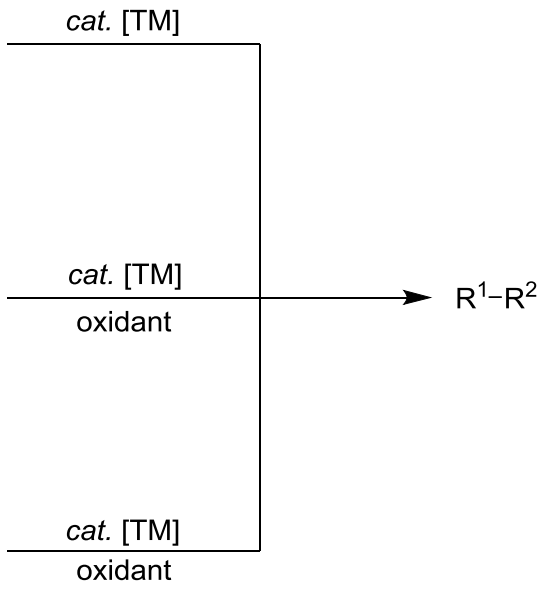

Scheme 8: Comparison of $\mathrm{C}-\mathrm{H}$ functionalisation strategies.

Friedel-Crafts-alkylation represents an early example of the synthesis of alkylated arenes (Scheme 9). ${ }^{20}$

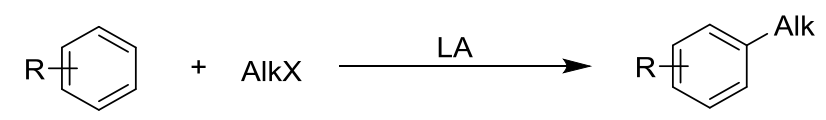

Scheme 9: General equation for the Friedel-Crafts-Alkylation.

It is, however, not considered as $\mathrm{C}-\mathrm{H}$ activation, because $\mathrm{C}-\mathrm{H}$ activations rely on organometallic intermediates. The term $\mathrm{C}-\mathrm{H}$ activation is commonly applied to reactions, in which the active metal catalyst performs a direct $\mathrm{C}-\mathrm{H}$ metalation. ${ }^{21}$ For these $\mathrm{C}-\mathrm{H}$ metalations, five mechanistic scenarios have so far been widely accepted (Scheme 10). ${ }^{22}$

\footnotetext{
${ }^{20}$ Bandini, M.; Umani-Ronchi, A. Catalytic Asymmetric Friedel-Crafts Alkylations, Wiley-VCH Verlag GmbH \& Co. KGaA, Weinheim, 2009.

${ }^{21}$ (a) Sezen, B.; Sames, D. What is $\mathrm{C}-\mathrm{H}$ bond activation, in Handbook of $\mathrm{C}-\mathrm{H}$ transformations, Wiley-VCH Verlag GmbH \& Co. KGaA, Weinheim, 2005. (b) Shilov, A. E.; Shul'pin, G. B. Chem. Rev. 1997, 97, $2879-2932$.

22 (a) Ackermann, L. Chem. Rev. 2011, 111, 1315-1345. (b) Balcells, D.; Clot, E.; Eisenstein, E. Chem. Rev. 2010, 110, 749-823. (c) Boutlada, Y.; Davies, D. L.; Macgregor, S. A.; Poblador-Bahamonde, A. I. Dalton Trans. 2009, 5820-5831.
} 
(a) oxidative addition

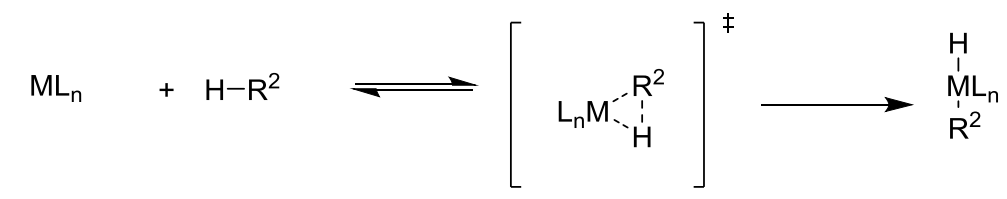

(b) $\sigma$-bond metathesis

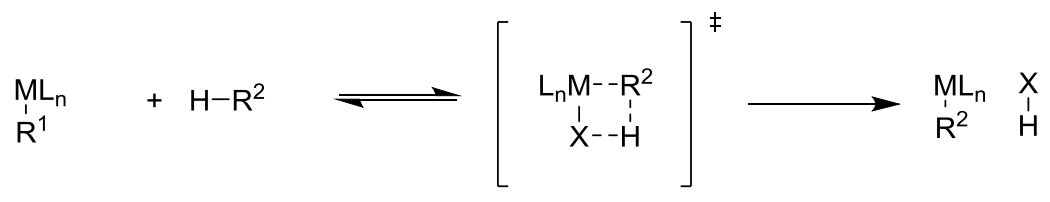

(c) 1,2-addition

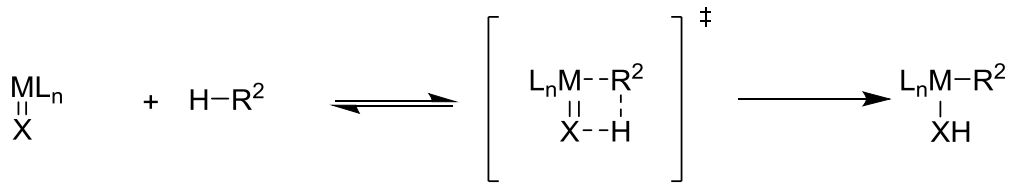

(d) electrophilic substitution<smiles></smiles>

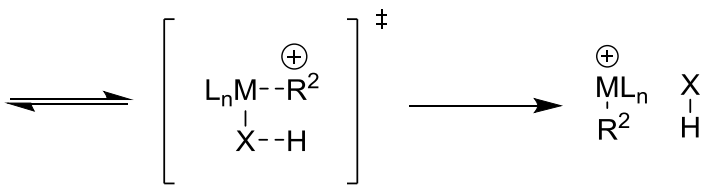

(e) base-assisted deprotonation

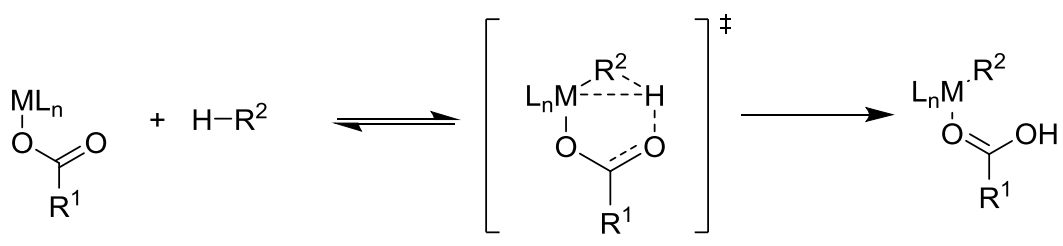

Scheme 10: Mechanistic pathways for $\mathrm{C}-\mathrm{H}$ activation.

The oxidative addition mechanism usually occurs in the case of electron-rich, low-valent latetransition metal catalysts, such as iridium, platinum and ruthenium. For the $\sigma$-bond metathesis pathway early transition metals and lanthanoids are typically employed. Somewhat similar mechanistically is the 1,2 addition, where a heteroatom is a hydrogen acceptor, is implemented by early or mid transition metals. For electrophilic substitution processes the metal catalyst reacts as a Lewis acid, most commonly with a hydroxy or alkoxy ligand. ${ }^{22 b}$ The base-assisted deprotonation, for example, uses secondary phsphine oxides or carboxylates, acting as an internal base. This pathway has been called either concerted metalation-deprotonation pathway or ambiphilic metal ligand activation. ${ }^{22 a}$ The latter two mechanistic pathways have also been investigated and illuminated in detail through DFT studies. $^{22 a, c}$

Selectivity is of key importance in $\mathrm{C}-\mathrm{H}$ activation chemistry. The organic compounds of interest possess many $\mathrm{C}-\mathrm{H}$ bonds of comparable dissociation energy and therefore achieving chemo- and regioselectivity is challenging. In order to differentiate between various chemically similar $\mathrm{C}-\mathrm{H}$ bonds several strategies have been developed. These include differentiation through assistance of a Lewis-basic directing group within the substrate, differently electronically activated $\mathrm{C}-\mathrm{H}$ bonds and sterical bulk in combination with catalyst control (Scheme 11). ${ }^{23}$

\footnotetext{
${ }^{23}$ Neufeldt, S. R.; Sanford, M. S. Acc. Chem. Res. 2012, 45, 936-946.
} 
(a)<smiles>Oc1ccccc1O</smiles>

(b)

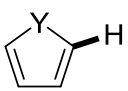

(c)<smiles>[R]c1cc([R])cc([1H])c1</smiles>

Scheme 11: Strategies for site-selectivity in C-H functionalisation via (a) lewis-basic directing group (b) electronic bias and (c) steric bulk with catalyst based control.

Considering these various approaches a wide variety of catalytic $\mathrm{C}-\mathrm{H}$ functionalisation reactions have been developed with transition metals employed including, for example, ruthenium, ${ }^{24}$ rhodium, ${ }^{25}$ palladium, ${ }^{26}$ manganese, ${ }^{27}$ iron, ${ }^{28}$ cobalt ${ }^{29}$ and nickel. ${ }^{30}$ The transformations facilitated by these catalysts include alkenylations (Scheme 12a+b) and arylations (Scheme 12c). ${ }^{31}$ One of the earliest examples for an alkenylation reaction is the Fujiwara-Moritani reaction (Scheme 12a). ${ }^{32}$ However, in this case the arene (36) was required in large excess. Further development took advantage of directing groups to give rise to a variety of protocols for such transformations (Scheme $12 \mathrm{~b}$ ). ${ }^{33}$ Remarkably, using an

\footnotetext{
${ }^{24}$ Seminal works:(a) Lewis, L. N.; Smith, J. F. J. Am. Chem. Soc. 1986, 108, 2728-2735. (b) Murai, S.; Kakiuchi, F.; Sekine, S.; Tanaka, Y.; Kamatani, A.; Sonoda, M.; Chatani, N. Nature 1993, 366, 529-531. ;for recent reviews see: (a) Ackermann, L. Acc. Chem. Res. 2014, 47, 281-295. (b) De Sarkar, S.; Liu, W.; Kozhushkov, S. I.; Ackermann, L. Adv. Synth. Catal. 2014, 356, 1461-1479. (c) Kozhushkov, S. I.; Ackermann, L. Chem. Sci. 2013, 4, 886-896. (d) Arockiam, P. B.; Bruneau, C.; Dixneuf, P. H. Chem. Rev. 2012, 112, 5879-5918. (f) Ackermann, L.; Vicente, R. Top. Curr. Chem. 2010, 292, 211-229.

${ }^{25}$ (a) Ye, B.; Cramer, N. Acc. Chem. Res. 2015, 48, 1308-1318. (b) Song, G.; Li, X. Chem. Soc. Rev. 2012, 41, 3651-3678. (c) Satoh, T.; Miura, M. Chem. Eur. J. 2010, 16, 11212-11222. (d) Colby, D. A.; Bergman, R. G.; Ellman, J. A. Chem. Rev. 2010, 110, 624-655.

${ }^{26}$ (a) Qiu, G.; Wu, J. Org. Chem. Front. 2015, 2, 169-178. (b) Engle, K. M.; Yu, J.-Q. J. Org. Chem. 2013, 78, 89278955. (c) Wencel-Delord, J.; Dröge, T.; Liu, F.; Glorius, F. Chem. Soc. Rev. 2011, 40, 4740-4761. (d) Yeung, C. S.; Dong, V. M. Chem. Rev. 2011, 111, 1215-1292.

${ }^{27}$ (a) Liu, W.; Ackermann, L. ACS Catal. 2016, 6, 3743-3752 (b) Liu, W.; Zell, D.; John, M.; Ackermann, L. Angew. Chem. Int. 2015, 54, 4092-4096. (c) Liu, W.; Bang, J.; Zhang, Y.; Ackermann, L. Angew. Chem. Int. Ed. 2015, 54, 14137-14140. (d) Liu, W.; Groves, J. T. Acc. Chem. Res. 2015, 48, 1727-1735. (e) Wang, C. Synlett 2013, 24, 1606-1613.

${ }^{28}$ (a) Mihovilovic, M. D.; Schnürch, M. ChemCatChem 2014, 6, 2194-2196. (b) Sun, X.; Li, J.; Huang, X.; Sun, C. Curr. Inorg. Chem. 2012, 2, 64-85. (c) Nakamura, E.; Yoshikai, N. J. Org. Chem. 2010, 75, 6061-6067.

${ }^{29}$ (a) Moselage, M.; Li, J.; Ackermann, L. ACS Catal. 2016, 6, 498-525 (b) Gao, K.; Yoshikai, N. Acc. Chem. Res. 2014, 47, 1208-1219. (c) Ackermann, L. J. Org. Chem. 2014, 79, 8948-8954. (d) Yoshikai, N. J. Synth. Org. Chem. 2014, 72, 1198-1206.

${ }^{30}$ (a) Castro, L. C. M.; Chatani, N. Chem. Lett. 2015, 44, 410-421. (b) Johnson, S. A. Dalton Trans. 2015, 44, 10905-10913.

${ }^{31}$ Selected examples: (a) Li, J.; Ackermann, L. Chem. Eur. J. 2015, 21, 5718-5722. (b) Diers, E.; Kumar, N. Y. P.; Mejuch, T.; Marek, I.; Ackermann, L. Tetrahedron 2013, 69, 4445-4453. (c) Yoshikai, N.; Matsumoto, A.; Norinder, J.; Nakamura, E. Angew. Chem. Int. Ed. 2009, 48, 2925-2928. (d) Satoh, T.; Kametani, Y.; Terao, Y.; Miura, M.; Nomura, M. Tetrahedron Lett. 1999, 40, 5345-5348.

32 (a) Moritani, I.; Fujiwara, Y. Tetrahedron Lett. 1967, 8, 1119-1122. (b) Fujiawara, Y.; Moritani, I.; Danno, S.; Asano, R.; Teranishi, S. J. Am. Chem. Soc. 1969, 91, 7166-7169.

${ }^{33}$ Selected examples: (a) Wang, Y.; Li, C.; Li, Y.; Yin, F.; Wang, X.-S. Adv. Synth. Catal. 2013, 355, 1724-1728. (b) Ackermann, L.; Wang, L.; Wolfram, R. ; Lygin, A. V. Org. Lett. 2012, 14, 728-731. (c) Cai, G.; Fu, Y.; Li, Y.; Wan, X.; Shi, Z. J. Am. Chem. Soc. 2007, 129, 7666-7673. (b) Boele, M. D. K.; van Strijdonck, G. P. F.; de Vries, A. H. M.; Kamer, P. C. J.; de Vries, J. G.; van Leeuwen, P. W. N. M. J. Am. Chem. Soc. 2002, 124, 1586-1587.
} 
appropriate directing group, alkenylation could also be achieved with meta-selectivity with regard to the directing group. ${ }^{34}$

(a) Fujiwara-Moritani reaction<smiles>[R]C=C([R])[R]</smiles>

(b) Chelation-assisted C-H Alkenylation

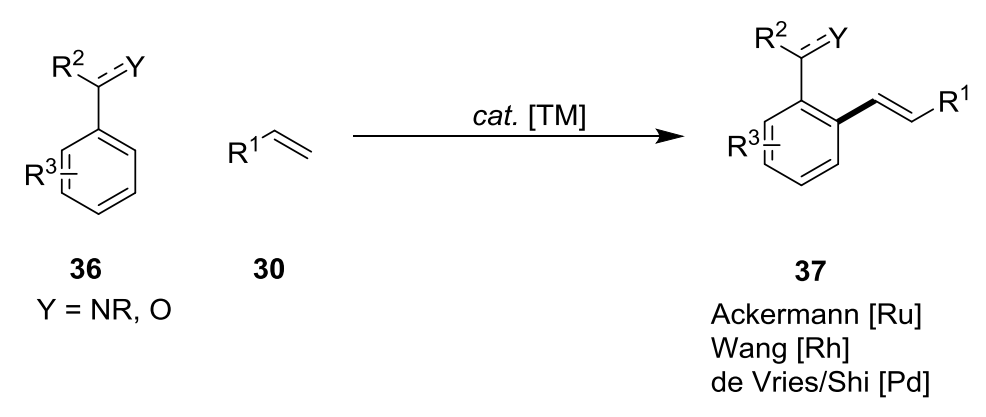

(c) Chelation-assisted $\mathrm{C}-\mathrm{H}$ Arylation

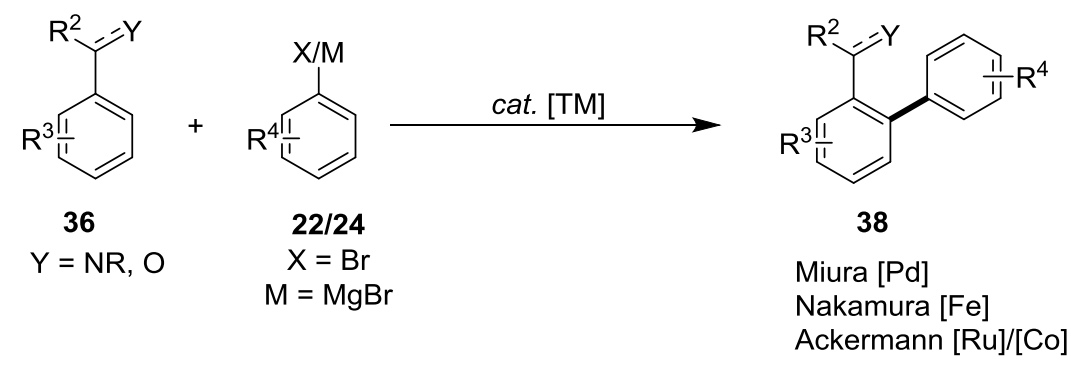

Scheme 12: (a) Fujiwara-Moritani reaction and (b) selected examples of directed C-H olefination and (c) arylation.

A broad range of heterocycles have been accessed using $\mathrm{C}-\mathrm{H}$ functionalisation via oxidative annulation reactions (Scheme 13). The stoichiometric oxidant in these reactions can either be another metal, such as copper, ${ }^{35}$ internal oxidants in the form of hetero-hetero-bonds ${ }^{36}$

\footnotetext{
${ }^{34}$ (a) Wang, X.-C.; Gong, W.; Fang, L.-Z.; Zhu, R.-Y.; Li, S.; Engle, K. M.; Yu, J.-Q. Nature 2015, 519, 334-338. (b) Tang, R.-Y.; Li, G.; Yu, J.-Q. Nature 2014, 507, 215-220. (c) Leow, D.; Li, G.; Mei, T.-S.; Yu, J-Q. Nature 2012, 486, 518-522.

${ }^{35}$ (a) Ackermann, L. Acc. Chem. Res. 2014, 47,281-295. (b) Pham, M. V.; Ye, B.; Cramer, N. Angew. Chem. Int. Ed. 2012, 51, 10610-10614. (c) Satoh, T.; Miura, M. Chem. Eur. J. 2010, 16, 11212-11222. (d) Pham, M. V.; Ye, B.; Cramer, N. Angew. Chem. Int. Ed. 2012, 51, 10610-10614. (e) Song, G.; Chen, D.; Pan, C.-L.; Crabtree, R. H.; Li, X. J. Org. Chem. 2010, 75, 7487-7490. (f) Su, Y.; Zhao, M.; Han, K.; Song, G.; Li, X. Org. Lett. 2010, 12, 5462-5465. (g) Hyster, T. K.; Rovis, T. J. Am. Chem. Soc. 2010, 132, 10565-10569. (h) Guimond, N.; Fagnou, K. J. Am. Chem. Soc. 2009, 131, 12050-12051. (i) Ueura, K.; Satoh, T.; Miura, M. Org. Lett. 2007, 9, 1707-1409.

${ }^{36}$ (a) Koornhaaß, C.; Kuper, C.; Ackermann, L. Adv. Synth. Catal. 2014, 356, 1619-1624. (b) Guimond, N.; Gorelsky, S. I.; Fagnou, K. J. Am. Chem. Soc. 2011, 133, 6449-6457. (c) Ackermann, L.; Fenner, S. Org. Lett. 2011, 13, 6548-6551. (d) Guimond, N.; Gouliaras, C.; Fagnou, K. J. Am. Chem. Soc. 2010, 132, 6908-6909.
} 
or, ideally, aerial oxygen. ${ }^{37}$ Apart from the relatively common annulation reactions towards six-membered heterocycles, it should be noted that the synthesis of compounds with other ring sizes through $\mathrm{C}-\mathrm{H}$ functionalisation have also been achieved. ${ }^{38}$

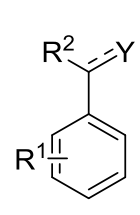

36 $\mathrm{Y}=\mathrm{NH}, \mathrm{OH}$<smiles>[R][R]#[R]</smiles><smiles>Ic1ccccc1</smiles>

32<smiles>[R][Y]1c([R])c([R])c2cccc([R])c12</smiles>

39

Fagnou/Glorius/Satoh \& Miura [Rh] Ackermann $[\mathrm{Ru}]$

Scheme 13: General examples for oxidative annulations through $\mathrm{C}-\mathrm{H}$ functionalisation.

For direct $\mathrm{C}-\mathrm{H}$ alkylations two approaches have been very common. One is the hydroarylation of olefins (Scheme 14a). ${ }^{24 b, 39}$ The use of electrophilic alkyl halides directly has also been demonstrated (Scheme 14b). ${ }^{13,40}$

${ }^{37}$ (a) Warratz, S.; Koornhaaß, C.; Cajaraville, A.; Niepötter, B.; Stalke, D. Ackermann, L. Angew. Chem. Int. Ed. 2015, 54, 5513-5517. (b) Liegault, B.; Fagnou, K. Organometallics 2008, 27, 4841-4843. (c) Liegault, B.; Lee, D.; Huestis, M. P.; Stuart, D. R.; Fagnou, K. J. Org. Chem. 2008, 72, 5022-5028. (d) Stahl, S. S. Angew. Chem. Int. Ed. 2004, 43, 3400-3420.

${ }^{38}$ (a) Burns, D. J.; Lam, H. W. Angew. Chem. Int. Ed. 2014, 53, 9931-9935.(b) Seoane, A.; Casanova, N.; Quiñones, N.; Mascareñas, J. L.; Gulías, M. J. Am. Chem. Soc. 2014, 136, 834-837. (c) Stuart, D. R.; Alsabeh, P.; Kuhn, M.; Fagnou, K. J. Am. Chem. Soc. 2010, 132, 18326-18339. (d) Rakshit, S. Patureau, F. W.; Glorius, F. J. Am. Chem. Soc. 2010, 132, 8585-9587. (e) Stuart, D. R.; Bertrand-Laperle, M.; Burgess, K. M. N.; Fagnou, K. J. Am. Chem. Soc 2008, 130, 16474-16475.

${ }^{39}$ (a) Schinkel, M.; Marek, I.; Ackermann, L. Angew. Chem Int. Ed. 2013, 52, 3977-3980. (b) Kozhushkov, S. I.; Yufit, D. S.; Ackermann, L. Org. Lett. 2008, 10, 3409-3412. (c) Kakiuchi, F.; Murai, S. Acc. Chem. Res. 2002, 35, 826-834.

${ }^{40}$ Selected examples: (a) Graczyk, K.; Haven, T.; Ackermann, L. Chem. Eur. J. 2015, 21, 8812-8815. (b) Zhu, R.-Y; He, J.; Wang, X.-C.; Yu, J.-Q. J. Am. Chem. Soc. 2014, 136, 13194-13197. (c) Fruchey, E. R.; Monks, B. M.; Cook, S. P. J. Am. Chem. Soc. 2014, 136, 13130-13133. (d) Ilies, L.; Matsubara, T.; Ichikawa, S.; Asako, S.; Nakamura, E. J. Am. Chem. Soc. 2014, 136, 13126-13129. (e) Gao, K.; Yoshikai, N. J. Am. Chem. Soc. 2013, 135, 9279-9282. (f) Punji, B.; Song, W.; Shevchenko, G. A.; Ackermann, L. Chem Eur. J. 2013, 19, 10605-10610. (g) Ackermann, L.; Hofmann, N.; Vicente, R. Org. Lett. 2011, 13, 1875-1877. (h) Ackermann, L.; Novák, P.; Vicente, R.; Hofmann, N. Angew. Chem. Int. Ed. 2009, 48, 6045-6048. 
(a) Alkylation via Alkene Hydroarylation<smiles>[R]C([Y])c1c[R1]ccc1</smiles>

36

$\mathrm{Y}=\mathrm{NR}, \mathrm{O}$

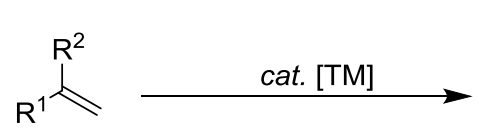

33<smiles>[R]C([Y])C([R])CC1=CC=[R1]#[R1]=C1</smiles>

40

[Ru] Murai, Ackermann

(b) Alkylation with Alkyl Halides<smiles>[R]C([Y])c1c[R1]ccc1</smiles><smiles>[R]C([R])[X]</smiles><smiles>C1CCC1</smiles>
41 $\mathrm{Y}=\mathrm{NR}, \mathrm{O} \quad \mathrm{X}=\mathrm{Cl}, \mathrm{Br}$<smiles>[R]C([Y])c1c[R1]ccc1C([R])[R]</smiles>

42

[Ru] Ackermann

[Co] Yoshikai, Ackermann

[Fe] Nakamura, Ackermann, Cook

Scheme 14: Strategies for direct alkylations via C-H functionalisation.

Beyond these $\mathrm{C}-\mathrm{C}$ bond forming reactions it should be noted that $\mathrm{C}-\mathrm{X}$ bond forming reactions have been thoroughly investigated, as well. These include $\mathrm{C}-\mathrm{H}$ aminations, ${ }^{41}$ oxygenations, $^{42}$ halogenations ${ }^{43}$ and thiolations. ${ }^{44}$

Given this plethora of procedures, $\mathrm{C}-\mathrm{H}$ functionalisation reactions have become viable for implementation within the total synthesis of natural products. This is demonstrated in the synthesis of dragmacidin $F(\mathbf{4 5})$ and hydratoaustamide (48) (Scheme 15). ${ }^{45}$

\footnotetext{
${ }^{41}$ Selected examples: (a) Minovilovic, M. D.; Schnürch, M. ChemCatChem 2014, 6, 2194-2196. (b) Gephart, R. T.; Warren, T. H. Organometallics 2012, 31, 7728-7752.

${ }^{42}$ Selected examples: (a) Yang, W.; Chen, H.; Li, J.; Li, C.; Wu, W.; Jiang, H. Chem. Commun. 2015, 51, 95759578. (b) Thirunavukkarasu, V. S.; Kozhushkov, S. I.; Ackermann, L. Chem. Commun. 2014, 50, 29-39. (c) Gary, J. B.; Cook, A. K.; Sanford, M. S. ACS Catal. 2013, 3, 700-703. (d) Gulevich, A. V.; Melkonyan, F. S.; Sarkar, D.; Gevorgyan, V. J. Am. Chem. Soc. 2012, 134, 5528-5531.

${ }^{43}$ Selected examples: (a) Miao, J.; Yang, K.; Kurek, M.; Ge, H. Org. Lett. 2015, 17, 3738-3741. (b) Wang, L.; Ackermann, L. Chem. Commun. 2014, 50, 1083-1085. (c) Wang, X.-C.; Hu, Y.; Bonacorsi, S.; Hong, Y.; Burrell, R.; Yu, J.-Q. J. Am. Chem. Soc. 2013, 135, 10326-10329. (c) Whitfield, S. R.; Sanford, M. S. J. Am. Chem. Soc. 2007, 129, 15142-15143.

${ }^{44}$ Selected examples: (a) Vásques-Céspedes, S.; Ferry, A.; Candish, L.; Glorius, F. Angew. Chem. Int. Ed. 2015, 54, 5772-5776. (b) Zhou, A.-X.; Liu, X.-Y.; Yang, K.; Zhao, S.-C.; Liang, Y.-M. Org. Biomol. Chem. 2011, 9, 5456-5462.

${ }^{45}$ (a) Gark, N. K.; Caspi, D. D.; Stoltz, B. M. J. Am. Chem. Soc. 2004, 126, 9552-9553. (b) Baran, P. S.; Corey, E. J. J. Am. Chem. Soc. 2002, 124, 7904-7905.
} 
(a)<smiles>CC1=CC[C@](O)(C(=O)c2cccn2[As]#N)C[C@H]1OC(C)(C)C</smiles>

43

4 $60^{\circ} \mathrm{C}, 10 \mathrm{~h}$

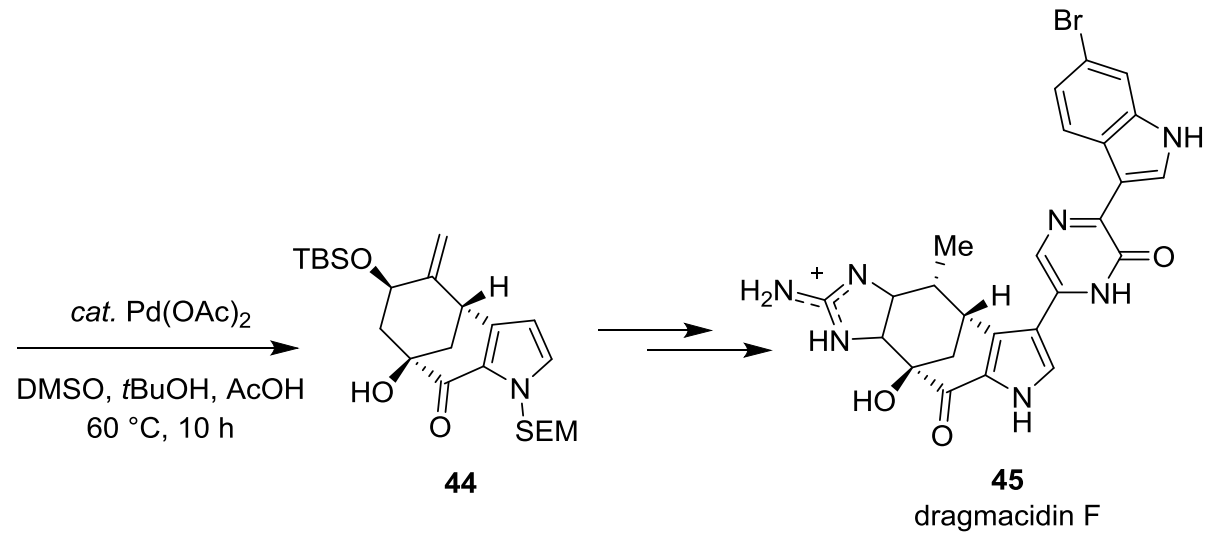

(b)

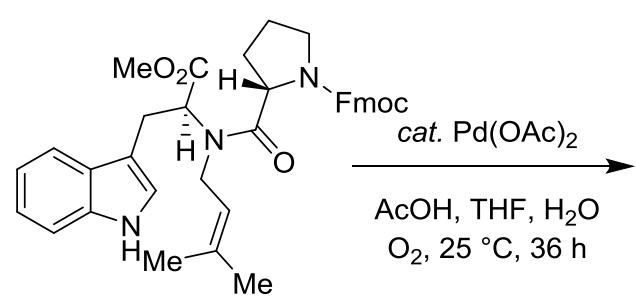

46

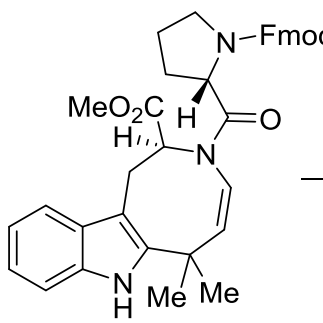

47

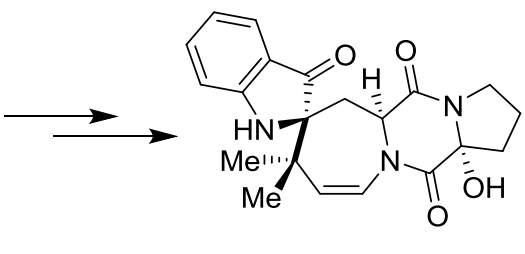

48

hydratoaustamide

Scheme 15: Total syntheses with C-H functionalization steps shown.

\subsection{Nickel-catalyzed C-H functionalization}

As highlighted a wide array of $\mathrm{C}-\mathrm{H}$ functionalisation reactions are possible with a range of transition metals ${ }^{24-30}$ and nickel has been featured relatively early. Indeed, in 1963 a stoichiometric direct $\mathrm{C}-\mathrm{H}$ nickelation of azobenzene was reported by Dubeck and Kleiman (Scheme 16). ${ }^{46}$

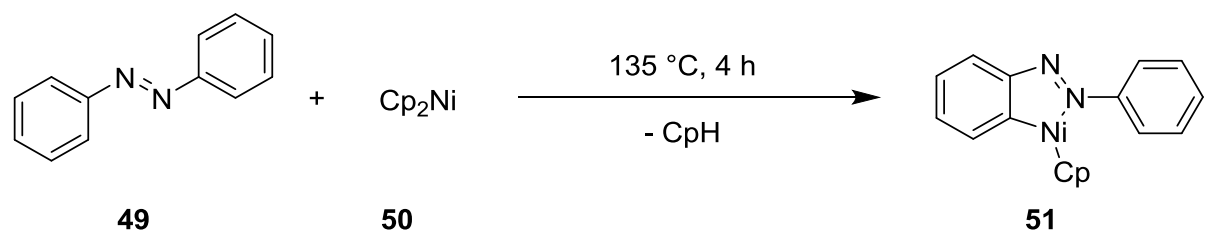

Scheme 16: Nickel-mediated C-H activation of azobenzene.

Early examples of such catalytic reactions were investigated by the groups of Miura, $\mathrm{Hu}$ and Ackermann. ${ }^{47,48}$ These reports originally focused on $\mathrm{C}-\mathrm{H}$ functionalisation of electronicallybiased azoles and included arylation ${ }^{47}$ and alkylation ${ }^{48}$ reactions as depicted in Scheme 17.

\footnotetext{
${ }^{46}$ Kleiman, J. P.; Dubeck, M. J. Am. Chem. Soc. 1963, 85, 1544-1545.

${ }^{47}$ (a) Muto, K.; Yamaguchi, J.; Itami, K. J. Am. Chem. Soc. 2012, 134, 169-172. (b) Hachiya, H.; Hirano, K.; Satoh, T.; Miura, M. Org. Lett. 2009, 11, 1737-1740. (c) Canivet, J.; Yamaguchi, J.; Ban, I.; Itami, K. Org. Lett. 2009, 11, 1733-1736. (d) Ackermann, L.; Althammer, A.; Fenner, S. Angew. Chem. Int. Ed. 2009, 48, 201-204.
} 
(a)<smiles>[Y]1cnc2ccccc12</smiles>

52

(b)

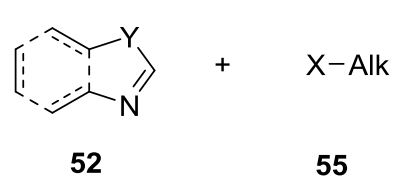
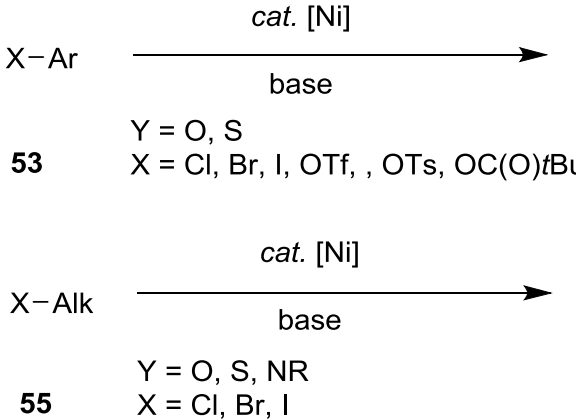<smiles>[Bi]C1=[Y]2C(=Nc3ccccc32)[In]1</smiles>

54<smiles>[H][Y]1c([AlH2])nc2ccccc12</smiles>

56

Scheme 17: Nickel-catalyzed C-H (a) arylation and (b) alkylation of azoles.

The utilisation of a Lewis-basic directing group for site-selective nickel-catalyzed $\mathrm{C}-\mathrm{H}$ functionalization was achieved after the conception of bidentate auxiliaries was introduced by the group of Daugulis for palladium-catalysed $\mathrm{C}-\mathrm{H}$ functionalisations. ${ }^{49}$ They found that otherwise inert $\mathrm{C}-\mathrm{H}$ bonds, could be functionalised, if a bidentate directing group was employed. Based on these findings the group of Chatani developed corresponding nickelcatalysed annulation, ${ }^{50}$ arylation $^{51}$ and primary alkylation ${ }^{52}$ reactions (Scheme 18 ).

(a)<smiles>O=C(NCc1ccccn1)c1cc[R1]cc1</smiles>

57

(b)<smiles>O=C(Nc1cccc2cccnc12)c1cc[R1]cc1</smiles>

59

(c)<smiles>O=C(Nc1cccc2cccnc12)c1cc[R1]cc1</smiles>

59

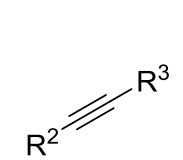

32

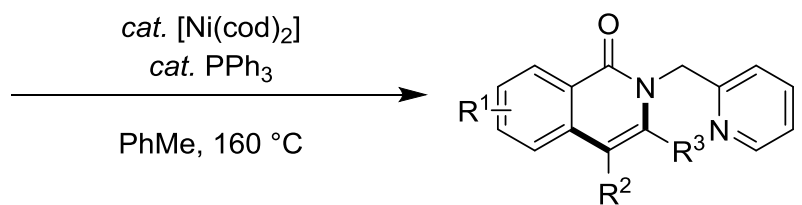

58

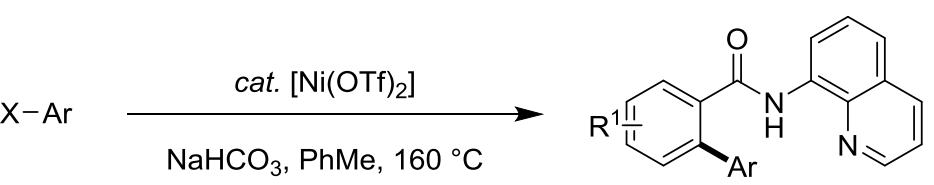

53

$$
\mathrm{X}=\mathrm{Br}, \mathrm{I}
$$

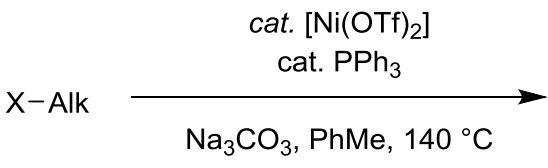

$\mathrm{X}=\mathrm{Cl}, \mathrm{Br}, \mathrm{I}$
60<smiles>O=C(Nc1cccc2cccnc12)c1cc[R1]cc1[Al]</smiles>

61

Scheme 18: Nickel-catalyzed direct C-H (a) annulation, (b) arylation and (c) primary alkylation under bidentate assistance.

Taking advantage of this enhanced reactivities towards $\mathrm{C}-\mathrm{H}$ bonds it was recently rendered possible to activate $\mathrm{C}\left(\mathrm{sp}^{3}\right)-\mathrm{C}-\mathrm{H}$ bonds in a similar fashion (Scheme 19). ${ }^{53}$

\footnotetext{
${ }^{48}$ (a) Ackermann, L.; Punji, B.; Song, W. Adv. Synth. Catal. 2011, 353, 3325-3329. (b) Vechorkin, O.; Proust, V.; $\mathrm{Hu}, \mathrm{X}$. Angew. Chem. Int. Ed. 2010, 49, 3061-3064.

${ }^{49}$ Daugulis, O.; Roane, J.; Tran, L. D. Acc. Chem. Res. 2015, 48, 1053-1064.

${ }^{50}$ Shiota, H.; Ano, Y.; Aihara, Y.; Fukumoto, Y.; Chatani, N. J. Am. Chem. Soc. 2011, 133, 14952-14955.

${ }^{51}$ Yokota, A.; Aihara, Y.; Chatani, N. J. Org. Chem. 2014, 79, 11922-11932.

${ }^{52}$ Aihara, N.; Chatani, N. J. Am. Chem. Soc. 2013, 135, 5308-5311.

53 (a) Aihara, Y.; Chatani, N. J. Am. Chem. Soc. 2014, 136, 898-901. (b) lyanaga, M.; Aihara, Y.; Chatani, N. J. Org. Chem. 2014, 79, 11933-11939. (c) Wu, X.; Zhao, Y.; Ge, H. J. Am. Chem. Soc. 2014, 136, 1789-1792.
} 
(a)<smiles>[Y][Al]</smiles>

62

(b)<smiles>[Y][AlH2]</smiles>

62

53

55

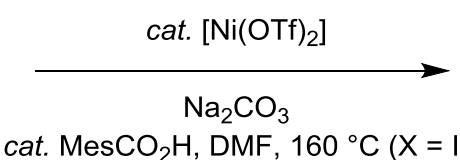

MTHP, $140^{\circ} \mathrm{C}(\mathrm{X}=[\mathrm{I}-\mathrm{Mes}] \mathrm{OTf})$

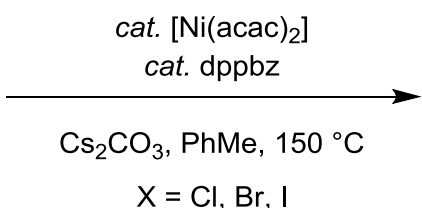

$\mathrm{X}=\mathrm{Cl}, \mathrm{Br}$,<smiles>[R]C([R])(C[Al])C(=O)Nc1cccc2cccnc12</smiles>

63<smiles>[R]C([R])(C[Al])C(=O)Nc1cccc2cccnc12</smiles>

64

Scheme 19: Examples of $\mathrm{C}\left(\mathrm{sp}^{3}\right)-\mathrm{C}-\mathrm{H}$ functionalisation through Nickel-catalysis.

The bidentate approach has remained most commonly used within directed nickel-catalyzed $\mathrm{C}-\mathrm{H}$ functionalization. However, monodentate strategies have been less prevalent. One instance is the nickel-catalysed oxidative annulation of oximes developed by Matsubara (Scheme 20a). ${ }^{54}$ Another are two annulation reactions reported by Hiyama ${ }^{55}$ and Ackermann ${ }^{56}$ respectively (Scheme $20 \mathrm{~b}$ and c).

(a)<smiles>[R]/C(=N\O)c1cc[14c]([R])cc1</smiles>

65<smiles>[R]C#[R]</smiles>

32

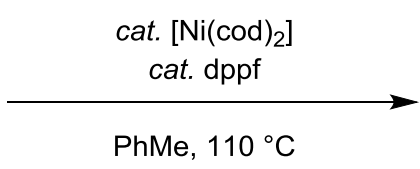

PhMe, $110^{\circ} \mathrm{C}$

(b)<smiles>CC([Al])C(C=O)C([Al])[Al]</smiles>

67

(c)<smiles>[R1]1ccc(Nc2ncccn2)cc1</smiles>

69<smiles>[R]C#[R]</smiles>

32

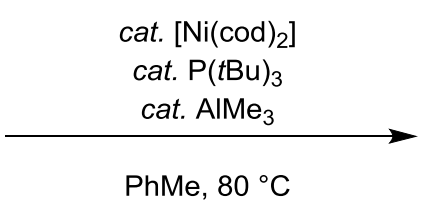

PhMe, $80^{\circ} \mathrm{C}$<smiles>[R]C#[R]</smiles>

32<smiles>[R]C=C1C=CC=C2C=C1C([R])=C([R])N=C2[R]</smiles>

66

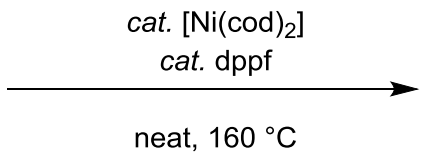

neat, $160^{\circ} \mathrm{C}$<smiles>[R]c1c2c(n(-c3ncccn3)c1[R])C=CC=[R1]N2</smiles>

70

Scheme 20: Nickel-catalyzed C-H functionalisations with monodentate auxiliaries.

\footnotetext{
${ }^{54}$ Yoshida, Y.; Kurahashi, T.; Matsubara, S. Chem. Lett. 2011, 40, 1140-1142.

${ }^{55}$ Nakao, Y.; Morita, E.; Idei, H.; Hiyama, T. J. Am. Chem. Soc. 2011, 133, 3264-3267.

${ }^{56}$ Song, W.; Ackermann, L. Chem. Commun. 2013, 49, 6638-6640.
} 
In addition, just as for other transition metals, protocols for the formation of $\mathrm{C}-\mathrm{X}$ bonds through $\mathrm{C}-\mathrm{H}$ bond functionalisation with nickel catalysts have recently been developed. These include borylation, ${ }^{57}$ sulfonylation, ${ }^{58}$ thiolation, ${ }^{59}$ amination ${ }^{60}$ and oxygenation reactions, ${ }^{61}$ although the latter example still being a nickel-mediated process. New heterogenous nickel-catalysts, such as the reusable, metal organic framework $\mathrm{Ni}_{2}(\mathrm{BDC})_{2}(\mathrm{DABCO})$, have emerged, as well. ${ }^{62}$

Nickel catalysis usually follows the previously mentioned modes for $\mathrm{C}-\mathrm{H}$ activation (vide supra Scheme 10). ${ }^{22}$ Oxidative addition pathways are often thought to be operative. However, the oxidation manifold has generally been unclear. In nickel-catalyzed alkylation chemistry three sets of probable oxidation states need to be considered for 2-electron changes, these being $\mathrm{Ni}(0) / \mathrm{Ni}(\mathrm{II}), \mathrm{Ni}(\mathrm{I}) / \mathrm{Ni}(\mathrm{III})$ and $\mathrm{Ni}(\mathrm{II}) / \mathrm{Ni}(\mathrm{IV})$.

A typical example involving a catalytic cycle proposed for $\mathrm{Ni}(0) / \mathrm{Ni}(\mathrm{II})$ intermediates involves the reaction of azoles. ${ }^{63}$ In some cases the homocoupled azole $\mathbf{7 1}$ has been isolated, through which a $\mathrm{Ni}(0)$ species is proposed to be generated (Scheme 21).

2

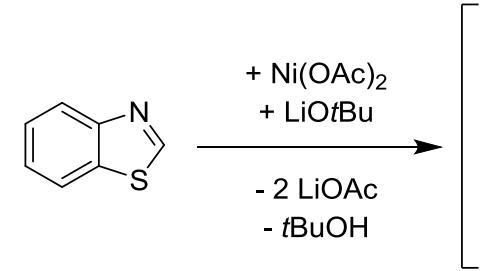

52

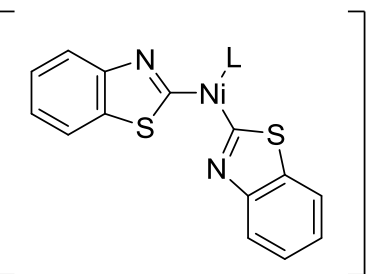

71

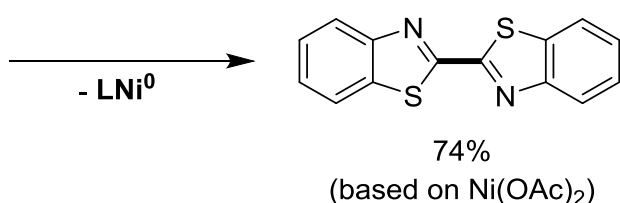

72

Scheme 21: Pathway for generation of nickel(0) species in the direct $\mathrm{C}-\mathrm{H}$ arylation of azoles.

The $\mathrm{Ni}(\mathrm{I}) / \mathrm{Ni}(\mathrm{III})$ manifold is commonly invoked within alkylation reactions. ${ }^{64}$ However, such conclusions are largely based on analogy to traditional cross coupling reactions, where isolated organonickel complexes were used for studies of the oxidative addition of unactivated alkyl halides. It has been established that the oxidative addition occurs through a single-electron-transfer, in which the alkyl halide is first bound to the nickel center and then a free organic radical is generated. Next, a rebound of the free organic radical occurs to form the new nickel-carbon bond. The initial $\mathrm{Ni}(\mathrm{I})$ species is often assumed to be only seemingly in this oxidation state, as the ligand may become redox-active. This however is mostly presumed for pyridine- and imin-based ligands (Scheme 22). Additional EPR

\footnotetext{
${ }^{57}$ Furukawa, T.; Tobisu, M.; Chatani, N. Chem. Commun. 2015, 51, 6508-6511.

${ }^{58}$ Yokota, A.; Chatani, N. Chem. Lett. 2015, 44, 902-904.

${ }^{59}$ (a) Zhu, J.; Chen, Y.; Lin, F.; Wang, B.; Chen, Z.; Liu, L. Org. Biomol. Chem. 2015, 13, 3711-3720. (b) Lin, C.; Yu, W.; Yao, J.; Wang, B.; Liu, Z.; Zhang, Y. Org. Lett. 2015, 17, 1340-1343.

${ }^{60}$ Yan, Q.; Chen, Z.; Yu, W.; Yin, H.; Liu, Z.; Zhang, Y. Org. Lett. 2015, 17, 2482-2485.

${ }^{61}$ Pattanayak, P.; Pratihar, J. L.; Patra, D.; Burrows, A.; Mohan, M.; Chattopadhyay Eur. J. Inorg. Chem. 2007, 4263-4271.

${ }^{62}$ Phan, N. T. S.; Nguyen, C. K.; Nguyen, T. T.; Truong, T. Catal. Sci. Technol. 2014, 4, 369-377.

${ }^{63}$ Yamamoto, T.; Muto, K.; Komiyama, M.; Canivet, J.; Yamaguchi, J.; Itami, K. Chem. Eur. J. 2011, 17, 1011310122.

${ }^{64} \mathrm{Hu}, \mathrm{X}$. Chem. Sci. 2011, 2, 1867-1886, and references cited therein.
} 
measurements conducted by $\mathrm{Fu}$ et al. confirmed the generation and importance nickel(I) intermediates. $^{65}$

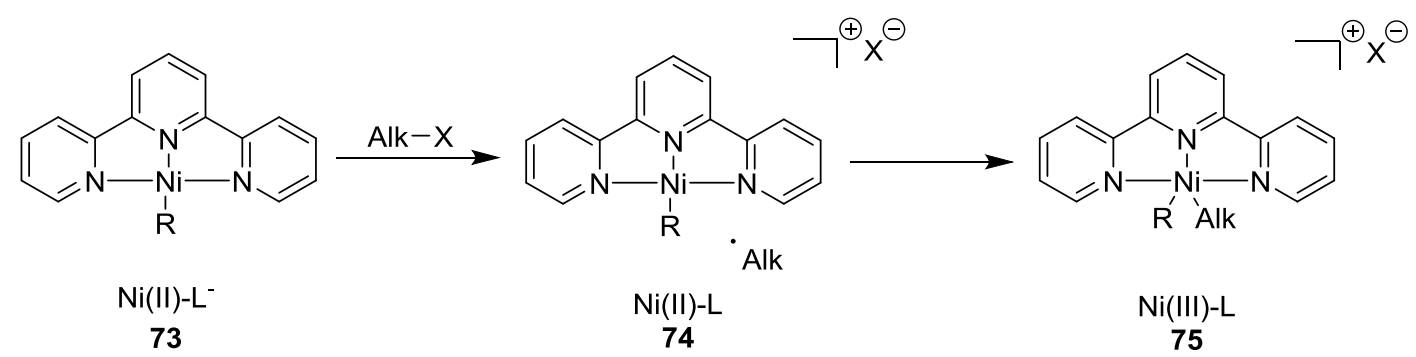

Scheme 22: Proposed intermediates for oxidative addition involving $\mathrm{Ni}(\mathrm{I}) / \mathrm{Ni}(\mathrm{III})$ oxidation states.

Furthermore, it could be considered that a $\mathrm{Ni}(\mathrm{IV})$ species could still be generated in these reactions, as a handful of $\mathrm{Ni}(\mathrm{IV})$-alkyl-complexes have been isolated. ${ }^{66}$ In case of complex 73 this was achieved by $\mathrm{C}-\mathrm{H}$ functionalization (Scheme 23). However, these are typically formed under strongly oxidizing reaction conditions.

(a)

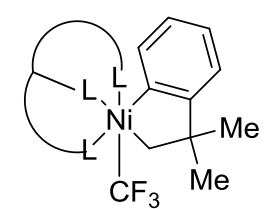

76

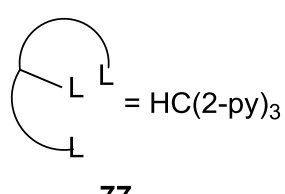

(b)<smiles>[R]C1CN2CCN(C1)C2</smiles>

78

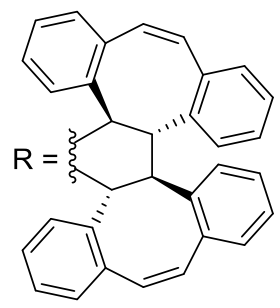

(c)

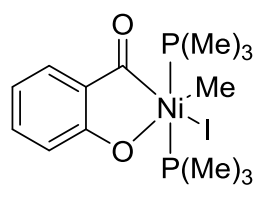

79

Scheme 23: Selected examples of nickel(IV)-alkyl-complexes.

${ }^{65}$ Schley, N. D.; Fu, G. C. J. Am. Chem. Soc. 2014, 136, 16588-16593.

${ }^{66}$ (a) Camasso, N. M.; Sanford, M. S. Science 2015, 347, 1218-1220. (b) Carnes, M.; Buccella, D.; Chen, J. Y.-C.; Ramirez, A. P.; Turro, N. J.; Nuckolls, C.; Steigerwald, M. Angew. Chem. Int. Ed. 2009, 48, 290-294. (c) Klein, HF.; Bickelhaupt, A.; Lemke, M.; Sun, H.; Brand, A.; Jung, T.; Röhr, C.; Flörke, U.; Haupt, H.-J. Organometallics 1997, 16, 668-676. 


\section{Objectives}

Efficient and selective alkylation and fluoroalkylation reactions are of key importance for numerous applied areas. Ongoing research within the group of Prof. Ackermann and the groups of others have developed a limited number of direct $\mathrm{C}-\mathrm{H}$ alkylations with various transition metals. ${ }^{13,40,48,52,53}$

At the outset of this thesis, a novel direct secondary alkylation, as well as trifluoroethylation, of benzamides under bidentate assistance was developed by the co-worker Dr. Weifeng Song. ${ }^{67}$ Based on this further expansion of the utilized secondary alkyl halides $\mathbf{8 0}$ was to be investigated (Scheme 24).

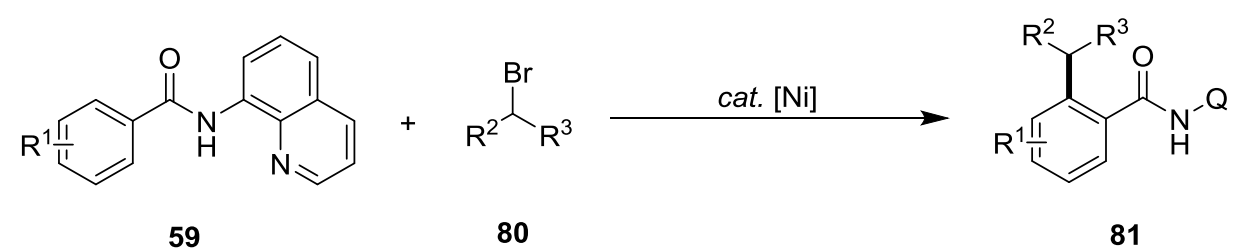

Scheme 24: Nickel-catalyzed bidentate-assisted secondary C-H alkylation.

Additionally, the applicability of the direct trifluoroethylation and perfluoroalkylation of variously decorated arenes was to be probed (Scheme 25). Furthermore, more detailed studies to elucidate the details of the mechanism for these catalytic reactions was to be carried out.

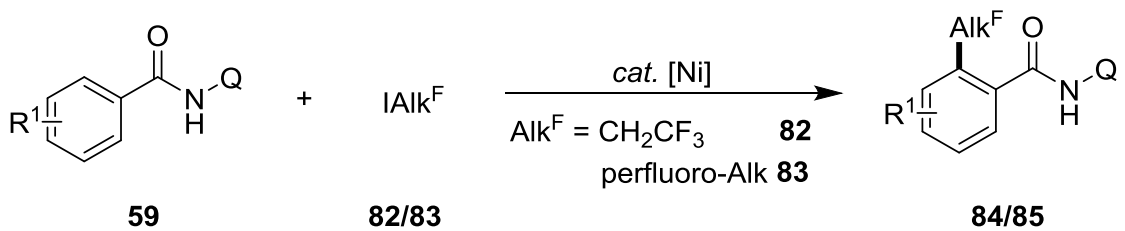

Scheme 25: Nickel-catalysed bidentate-assisted fluoroalkylation.

A noticeable disadvantage of these bidentate auxiliaries, however, is their relative large size, which effectively lowers their atom economy for possible applications within industry and total synthesis. ${ }^{49}$ Therefore, the development of simpler or biologically useful directing groups is of high interest. Based on previous findings for the efficient nickel-catalyzed synthesis of indoles from 2-pyrimidyl-anilines, the possibility to apply this useful directing group to the nickel-catalyzed alkylation and fluoroalkylation transformations was to be investigated. If successful, detailed mechanistic studies, particularly regarding the type of nickelacycle, were to be carried out. Further development of additional directing groups derived from the 2-pyrimidyl-anilines was also to be attempted (Scheme 26).

\footnotetext{
${ }^{67}$ Song, W. Cobalt- and Nickel- Catalyzed Functionalization of Unactivated C-Hal, C-O and C-H bonds. PhD Thesis, Georg-August-University, Göttingen, 2014.
} 
2 Objectives

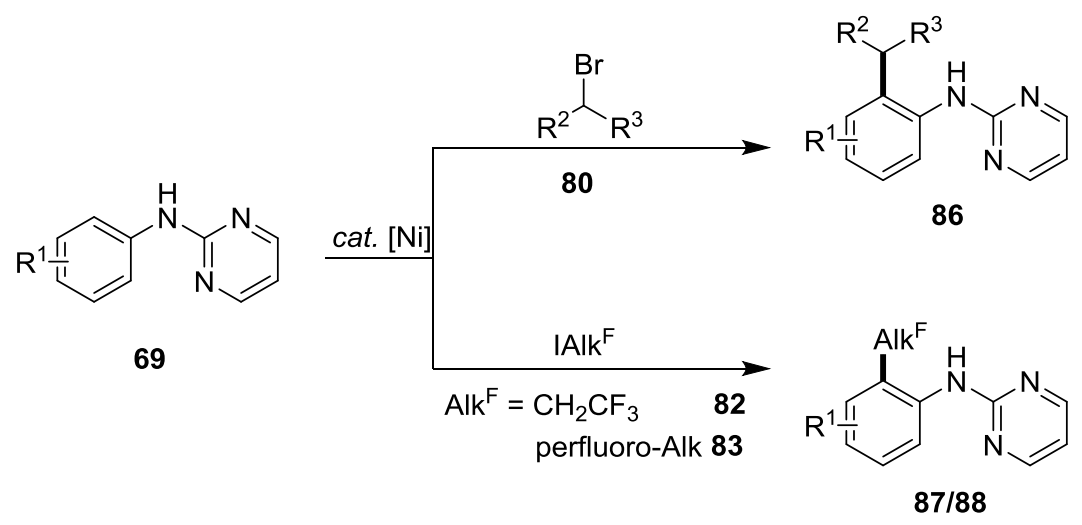

Scheme 26: Nickel-catalysed secondary C-H alkylations and fluoroalkylations of 2-pyrimidyl-anilines 69. 


\section{Results and Discussion}

\subsection{Direct $\mathrm{C}-\mathrm{H}$ secondary Alkylation under Bidentate Assistance}

As indicated in the introduction, direct $\mathrm{C}-\mathrm{H}$ alkylations with unreactive alkyl halides $\mathbf{8 0}$ are of high relevance. In this context a nickel-catalyzed secondary alkylation of benzamides $\mathbf{5 9}$ with bidentate auxiliaries, a catalytic system has been previously developed by our co-worker $\mathrm{Dr}$. Weifeng Song (Scheme 27). ${ }^{67}$<smiles>O=C(Nc1cccc2cccnc12)c1cc[R][14cH][14cH]1</smiles>

59<smiles>BrC1CCCCC1</smiles>

80d

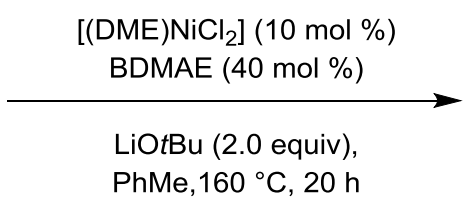

$\mathrm{PhMe}, 160^{\circ} \mathrm{C}, 20 \mathrm{~h}$

$$
\mathrm{Me}_{2} \mathrm{~N} \frown \mathrm{O} \sim \mathrm{NMe}_{2}=\operatorname{BDMAE}(89)
$$

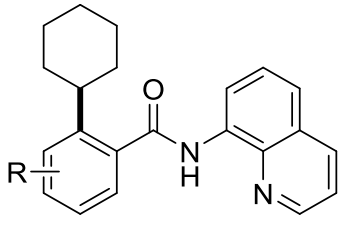

81

Scheme 27: System for nickel-catalyzed secondary alkylation of benzamides 59 .

Mechanistic studies conducted by Dr. Weifeng Song revealed a reversible $\mathrm{C}-\mathrm{H}$ metalation with the $\mathrm{C}-\mathrm{H}$ acidity being of relevance.

\subsubsection{Scope and Limitations}

Initially, cyclic alkyl bromides $\mathbf{8 0}$ were investigated (Scheme 28). Apart from cyclopropyl bromide $\mathbf{8 0 a}$, a wide range of alkyl halides with various ring sizes was well tolerated. It is also noteworthy that exo-bromo norbornane $\mathbf{8 0 f}$ furnished the corresponding alkylated benzamide 81af with retention of configuration. Only in the case of the bulkier 2-bromo adamantine $80 \mathrm{~g}$ did the conversion drop significantly. 

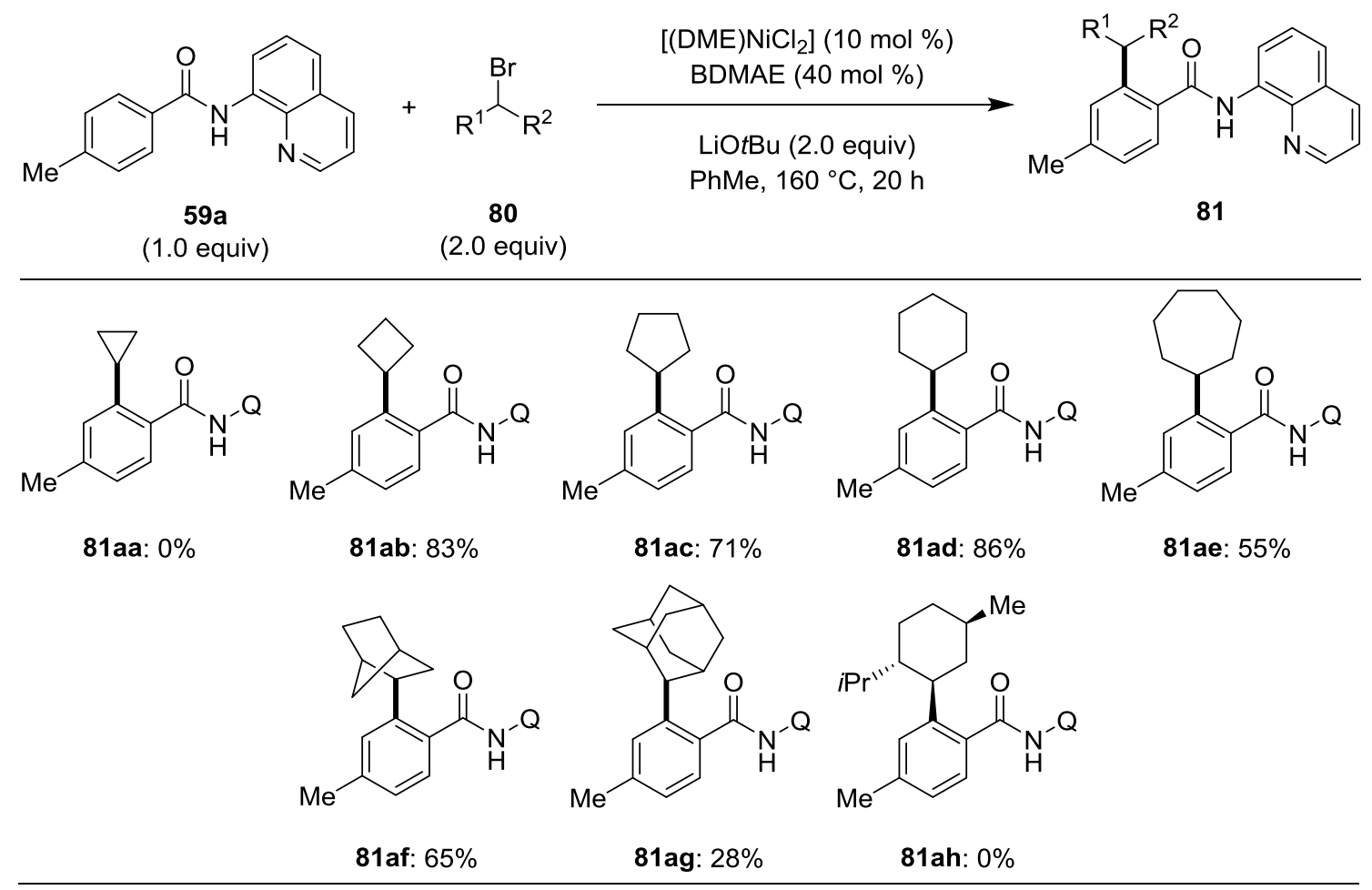

Scheme 28: Scope of secondary C-H alkylation of benzamide 59a with cyclic alkyl bromides 80.

For acyclic alkyl bromides $\mathbf{8 0}$ moderate yields were generally be obtained (Scheme 29). However, the trend of decreasing yields with increasing sterical demand of the alkyl chain was observed. In regards to functional groups, a protected amine in substrate $\mathbf{8 0 p}$ was well tolerated. Additional halides or unsaturated bonds, however, were not feasible.

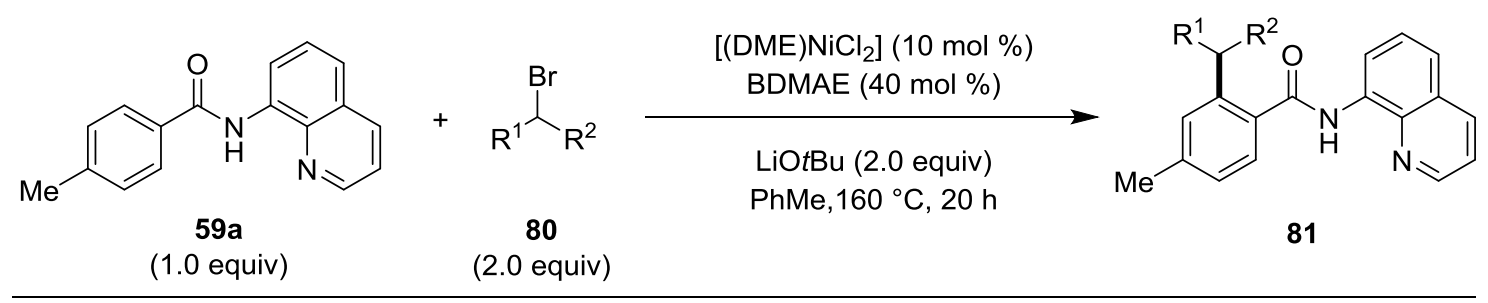<smiles>CCCCCC(C)c1cc(C)ccc1C(=O)NO[Na]</smiles><smiles>CONC(=O)c1ccc(C)cc1C(C)CCCC(C)C</smiles>

Scheme 29: Scope of secondary C-H alkylation of benzamide 59a with acyclic bromides 80. 
As the use of bidentate auxiliaries has proven to be impeccable, further possible variations of this basic principle were investigated (Scheme 30). These, however, proved to be incompatible with the optimized procedure.
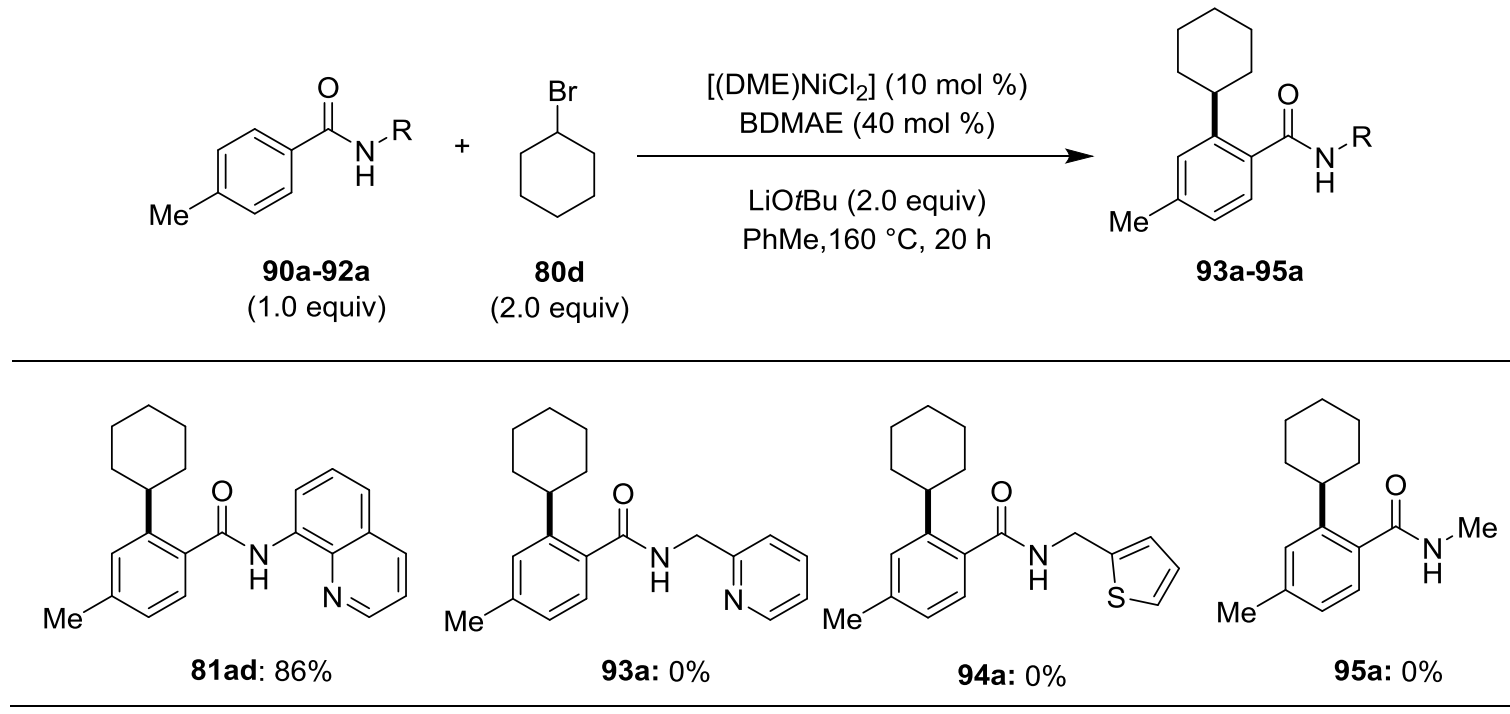

Scheme 30: Scope of alternative auxiliaries 90a-92a.

In an effort to achieve an enantioselective process a small selection of chiral ligands were probed next (Table 1). An enantiomeric excess could, however, not be observed. Based on previous protocols and findings from asymmetric nickel-catalysed cross-coupling reactions it can be reasoned that at temperatures significantly exceeding ambient temperature only low, if any, enantiomeric excess can be expected. ${ }^{68}$ Therefore, no further studies were conducted.

Table 1: Screening of ligands for asymmetric C-H alkylation. ${ }^{[a]}$

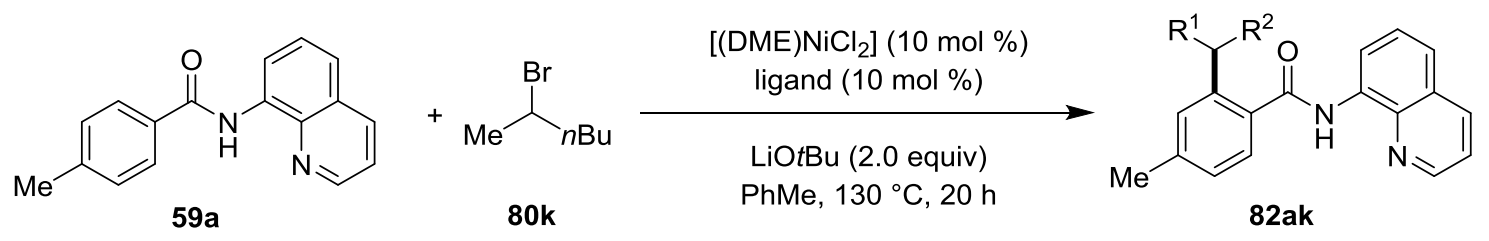

\begin{tabular}{|c|c|c|c|}
\hline Entry & ligand & Yield [\%] & ee [\%] \\
\hline 1 & (-)-pseudoephedrin (96) & 3 & 0 \\
\hline 2 & (L)-valinol (97) & 2 & 0 \\
\hline 3 & & (trace) & n. d. \\
\hline 4 & $\mathrm{Ph} \mathrm{Cl}^{\ominus} \mathrm{Ph}$ & (trace) & n. d. \\
\hline 5 & $(R)$-BINOL (100) & 56 & 0 \\
\hline
\end{tabular}

a Reactions conditions: 59a (1.0 mmol), 80k $(2.0 \mathrm{mmol})$, LiOtBu $(2.0 \mathrm{mmol})$, ligand, PhMe $(2 \mathrm{~mL})$, $130{ }^{\circ} \mathrm{C}, 20 \mathrm{~h}$, yields of isolated products.

${ }^{68}$ Liang, Y.; Fu, G. C. J. Am. Chem. Soc. 2014, 136, 5520-5524. 
In addition to the direct $\mathrm{C}\left(\mathrm{sp}^{2}\right)-\mathrm{H}$ alkylation, the applicability of the optimized system towards $\mathrm{C}\left(\mathrm{sp}^{3}\right)-\mathrm{H}$ alkylation was preliminarily tested. Although the yield was low, it could be shown that the reaction was in principle feasible (Scheme 31).
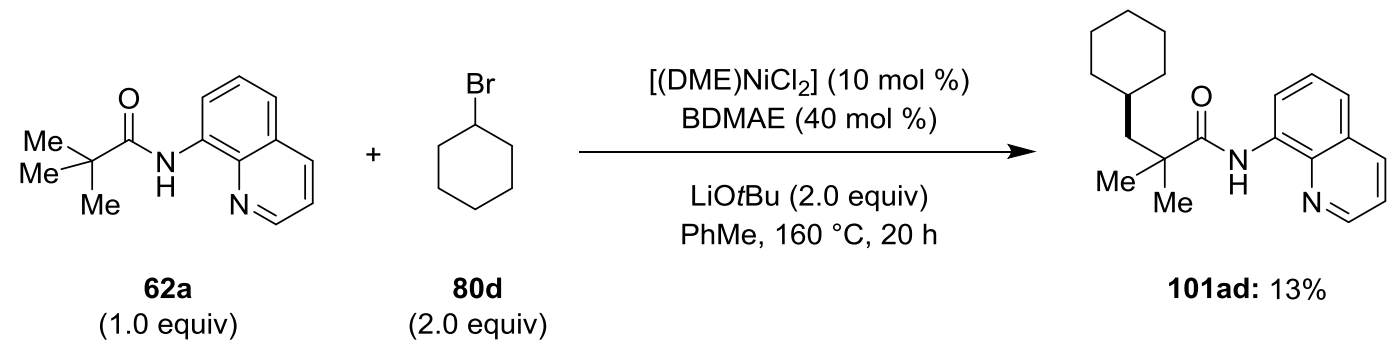

101ad: $13 \%$

Scheme 31: Direct $\mathrm{C}\left(\mathrm{sp}^{3}\right)-\mathrm{H}$ alkylation of amide 62a with $80 \mathrm{~d}$.

\subsubsection{Mechanistic Studies}

As to the reaction mechanism it could be shown that the conditions for primary alkylation, previously reported by Chatani et $a l^{52}$ were completely ineffective for challenging secondary $\mathrm{C}-\mathrm{H}$ alkylation (Scheme 32).

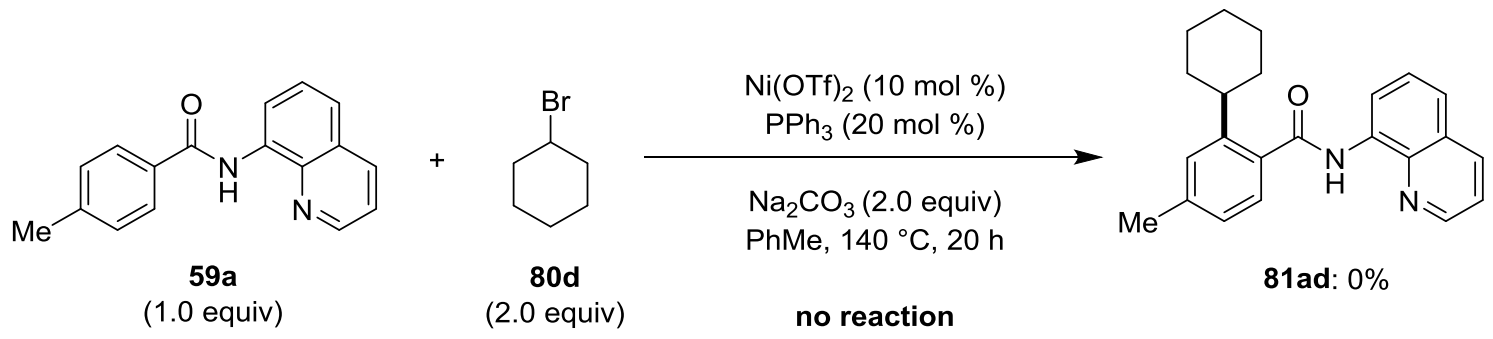

Scheme 32: Secondary C-H alkylation under conditions for primary alkylation.

Additionally, it was found that the reaction conditions for primary alkylation and the procedure for secondary alkylation were fully chemo-selective (Scheme 33).

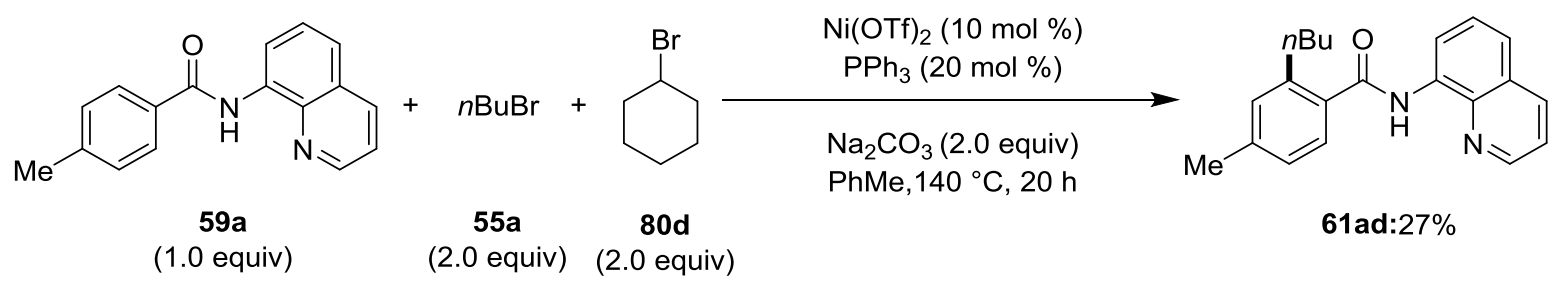

Scheme 33: Competition experiment between primary and secondary alkyl halide.

A competition experiment between 2-bromo hexane $\mathbf{8 0 k}$ and 3-bromo hexane $\mathbf{8 0 m}$ revealed that less sterically bulky substrates were significantly favoured (Scheme 34). 


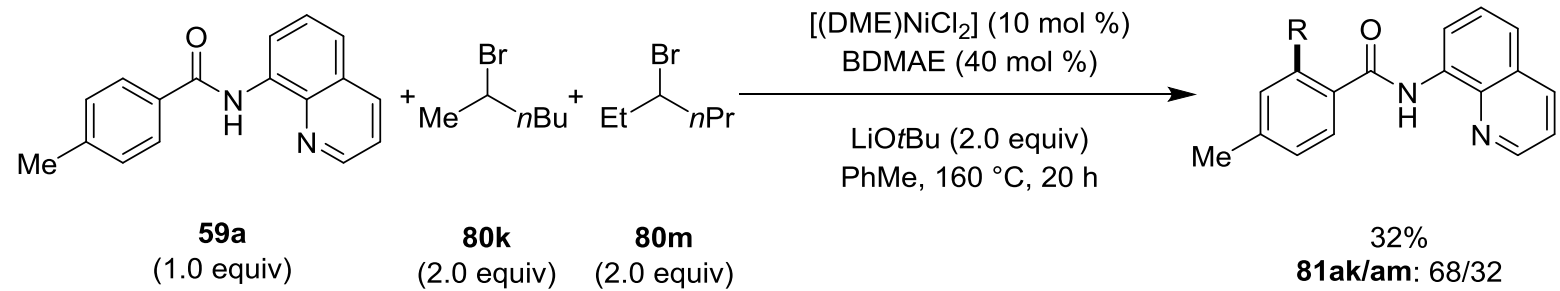

Scheme 34: Competition experiment between 2-bromo and 3-bromo hexane. 


\subsection{Direct C-H Trifluoroethylation under Bidentate Assistance}

Fluorinated compounds have a significant role in medicinal chemistry (vide supra). Therefore, based on the catalytic system for direct secondary alkylations it was found that the first trifluoroethylation using trifluoroethyl iodide $\mathbf{8 2}$ was accessable by the nickel catalyst. Without further optimisation a representative set of substrates $\mathbf{5 9}$ were tested (Scheme 35). While the yields were rather moderate, the feasibility of this novel transformation could be shown as a proof of concept study.

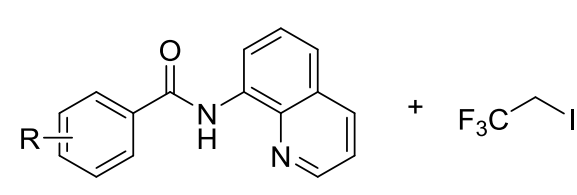

59

(1.0 equiv)

(2.0 equiv)

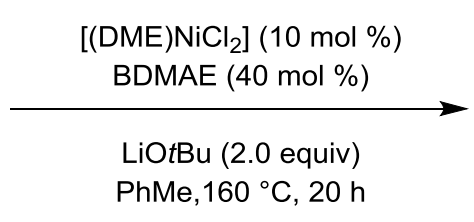

PhMe $160{ }^{\circ} \mathrm{C}, 20 \mathrm{~h}$

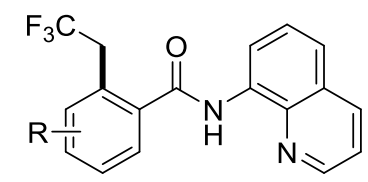

84<smiles>Cc1ccc(C(=O)NO)c(CC(F)(F)F)c1</smiles><smiles>O=C(NO)c1ccc(F)cc1CC(F)(F)F</smiles>

84b: $23 \%\left(7 \%\left[{ }^{[b]}\right)\right.$<smiles>CC(=O)Oc1ccc(C(=O)NO)c(CC(F)(F)F)c1</smiles>

84c: $0 \%$<smiles>O=C(NO)c1cc(C(F)(F)F)ccc1CC(F)(F)F</smiles>

84e: $35 \%$<smiles>O=C(NO)c1c(F)cccc1CC(F)(F)F</smiles>

84f: $29 \%$<smiles>O=C(NO)c1ccsc1CC(F)(F)F</smiles>

84g: $19 \%$

${ }^{[a]}$ Performed by Dr. Weifeng Song. ${ }^{[b]}$ Yield of the bis-trifluoroethylated product.

Scheme 35: Scope of Trifluoroethylation for benzamides 59.

Furthermore, based on a recently reported cross coupling transformation, ${ }^{69}$ the related direct fluoromethylation was investigated as well (Scheme 36). However, without any optimization this attempt did not yield the desired product 101a.<smiles>COc1ccc(C(=O)Nc2cccc3cccnc23)cc1</smiles>

(1.0 equiv)

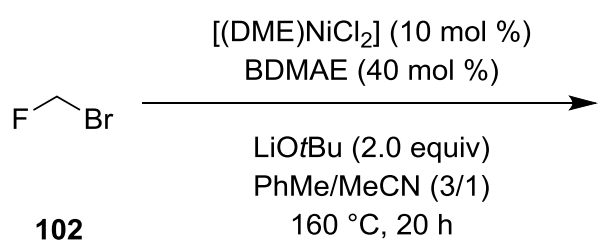

(1.0 equiv)<smiles>Cc1ccc(C(=O)Nc2cccc3cccnc23)c(CF)c1</smiles>

Scheme 36: Attempted fluoromethylation of benzamide 59a.

${ }^{69}$ An, L.; Xiao, Y.-L.; Min, Q.-Q.; Zhang, X. Angew. Chem. Int. Ed. 2015, 54, 9079-9083. 


\subsection{Direct Secondary C-H Alkylation of $\boldsymbol{N}$-Pyrimidyl-Anilines}

Mono-dentate directing groups are severely underrepresented within nickel-catalysed $\mathrm{C}-\mathrm{H}$ activation (vide supra). Therefore, based on the previously reported nickel-catalysed synthesis of indoles, ${ }^{56}$ a direct $\mathrm{C}-\mathrm{H}$ alkylation reaction utilising $\mathrm{N}$-(2-pyrimidyl)-anilines 69 was envisioned. These are particularly interesting targets for alkylation reactions, as various important pharmaceuticals contain the 2 -amino-pyrimidine motif. ${ }^{70}$ Two examples of such drugs are Gleevec 104 and Tasigna 105, both of which marketed by Novartis (Scheme 37). ${ }^{71}$
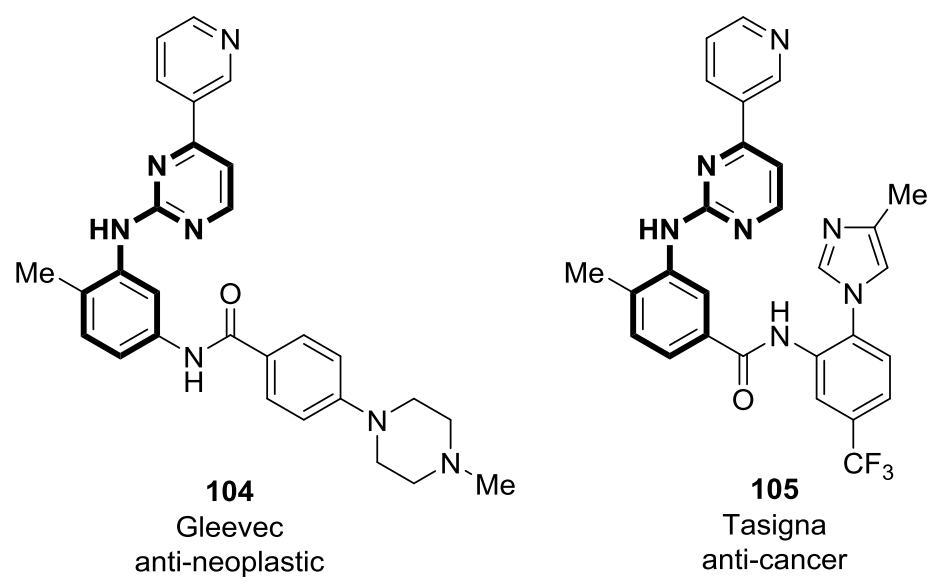

Scheme 37: Selected examples for marketed pharmaceuticals containing $\mathbf{N}$-(2-pyrimidyl)-anilines.

\subsubsection{Synthesis of Starting Materials}

For the aniline substrates 69 an additional pathway for their synthesis was developed. Based on the known literature, usually three synthetic pathways are used. First, transition metalcatalyzed amination reactions, most commonly using palladium or copper as the transition metal, can be utilised. ${ }^{72}$ This option can be rendered impractical, however, as trace amounts of the used transition metal need to be fully removed. This is typically achieved by distillation, which is often problematic due to the very high boiling point of these types of anilines 69. Second, an acid-catalyzed aromatic substitution can be achieved by using 2chloro-pyrimidine 106 . $^{73}$ This methodology, however, often gives low yields when employing

\footnotetext{
${ }^{70}$ (a) Kumar, S.; Deep, A.; Narasimhan, B. Cent. Nerv. Syst. Agents Med. Chem. 2015, 15, 5-10. (b) Kaur, R.; Kaur, P.; Sharma, S.; Singh, G.; Mehndiratta, S.; Bedi, P. M. S.; Nepali, K. Recent Pat. Anticancer Drug Discov. 2015, 10, 23-71. (c) Dongre, R. S.; Bhat, A. R.; Meshram, J. S. Am. J. PharmTech Res. 2014, 4, 138-155. (d) Rawat, B.; Rawat, D. S. Med. Res. Rev. 2013, 33, 693-764. (d) Selvam, T. P.; James, C. R.; Dniandev, P. V.; Valzita, S. K. Res. in Phar. 2012, 2, 1-9. (e) Weisberg, E.; Manley, P.; Mestan, J.; Cowan-Jacob, S.; Ray, A.; Griffin, J. Br. J. Cancer 2006, 94, 1765-1769.

${ }^{71}$ (a) Breccia, M.; Alimena, G Leuk. Res. 2010, 34, 129-134. (b) McGrath, N. A.; Brichacek, M.; Njardarson, J. T. J. Chem. Ed. 2010, 87, 1348-1349.

72 (a) Yin, J.; Zhao, M. M.; Huffman, M. A.; McNamara, J. M. Org. Lett. 2002, 4, 3481-3484. (b) Liu, Y.; Bai, Y.; Zhang, J.; Li, Y.; Jiao, J.; Qi, X. Eur. J. Org. Chem. 2007, 6084-6088.

${ }^{73}$ Ackermann, L.; Lygin, A. V. Org. Lett. 2012, 14, 764-767.
} 
anilines, which are electron-deficient or contain sterically demanding substituents in the ortho-position. The typically employed protic solvent can also react with the 2-chloropyrimidine 106 to give undesired side products. Last, a three-step synthesis via a guanidinium moiety reacting with a corresponding Michael acceptor is also possible. ${ }^{74}$ This approach, however, involves three steps with typically moderate yields. Also the scope of the substitution pattern in the 6-position of the pyrimidine is very narrow.

Hence, a more generally applicable methodology was needed and developed. Thus the nucleophilic aromatic substitution was employed without further optimisation (Scheme 38). Although the yields were generally rather moderate, otherwise unreactive anilines, such as 1-naphthylamine $(\mathbf{1 0 7} \mathrm{g})$, could be used here as well.

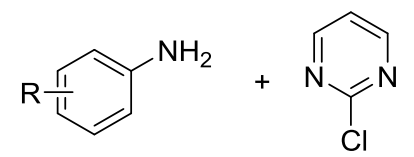

107 (2.0 equiv)

106

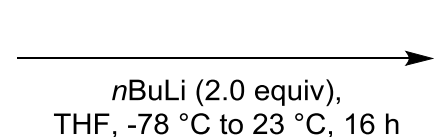

THF, $-78^{\circ} \mathrm{C}$ to $23^{\circ} \mathrm{C}, 16 \mathrm{~h}$

(1.0 equiv)

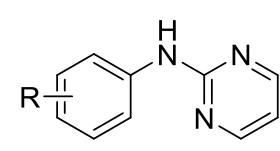

69<smiles>Fc1ccccc1Nc1ncccn1</smiles>

69a: $61 \%$<smiles>Cc1ccccc1Nc1ncccn1</smiles>

69b: $69 \%$<smiles>COc1ccccc1Nc1ncccn1</smiles>

69c: $37 \%$<smiles>CC(C)(C)c1ccccc1Nc1ncccn1</smiles>

69d: $50 \%$<smiles>c1ccc(-c2ccccc2Nc2ncccn2)cc1</smiles>

69e: $37 \%$<smiles>FC(F)(F)c1cccc(Nc2ncccn2)c1</smiles>

69f: $37 \%$<smiles>c1cnc(Nc2cccc3ccccc23)nc1</smiles>

69g: $42 \%$

Scheme 38: Scope of basic synthesis of 2-pyrimidyl anilines 69.

A Lewis acid-mediated method was also tested, in which the typically protic solvents or cosolvents were avoided (Scheme 39). Possibly due to the high reactivity of aluminium chloride the yields were low.<smiles>Cc1ccccc1N</smiles>

106
$\mathrm{AlCl}_{3}, \mathrm{THF}, 0^{\circ} \mathrm{C}$ to $23^{\circ} \mathrm{C}, 16 \mathrm{~h}$<smiles>Cc1ccccc1Nc1ncccn1</smiles>

$69 b: 26 \%$

Scheme 39: Lewis acid-mediated synthesis of 2-pyrimidyl aniline 69b.

\footnotetext{
${ }^{74}$ Wang, S.; Meades, C.; Wood, G.; Osnowski, A.; Anderson, S.; Yuill, R.; Thomas, M.; Mezna, M.; Jackson, W.; Midgley, C.; Griffiths, G.; Fleming, I.; Green, S.; McNae, I.; Wu, S.-Y.; Mclnees, C.; Zheleva, D.; Walkinshaw, M. D.; Fischer, P. M. J. Med. Chem. 2004, 47, 1662-1675.
} 


\subsubsection{Optimisation Studies}

At the outset of our studies, an initial test without additional ligand was performed and already furnished a low yield of desired product 83ad (Table 2, entry 1). Adding the previously established ligand BDMAE or TMEDA significantly improved the performance (Table 2, entries 2-3). Secondary amines were also found to be suitable ligands for this transformation (Table 2, entries 4-6, 9-10). Among these, secondary amine DtBEDA proved to be ideal, allowing a lowering of the catalyst loading to $2.5 \mathrm{~mol} \%$ (Table 2, entries $6-8)$. Surprisingly, 12 -crown-4 facilitated the reaction as well (Table 2 , entry 12). While nickel complexes with related crown ether moieties are known, ${ }^{75}$ it is unclear what type of coordination to nickel ions can occur during these type of reactions. Additionally, employing both, DtBEDA and 12-crown-4, together gives an intermediary yield (Table 2, entry 13). This may indicate a separate and possibly conflicting mode of action. Variation of the base showed that LiOtBu was the best choice. Changing the metal cation lead to a severe decrease in conversion (Table 2, entries 13-16). Conversely, a change towards weaker lithium bases also gave no conversion. This may indicate that either certain solubility properties are crucial or that the lithium cation itself may be involved in the catalytic reaction. The latter case might be possible, if the lithium precoordinates to the directing group, effectively changing its electronic properties. Such cases have been studied for cesium bases in palladium-catalyzed $\mathrm{C}-\mathrm{H}$ functionalisation. ${ }^{76}$ Only lithium bases were therefore used in further studies. Additional lowering of the catalyst loading lead to trace conversion (Table 2, entries 18-19). Without catalyst no conversion towards the desired product was observed (Table 2, entry 20).

Table 2: Optimisation studies for secondary alkylation of anilines. ${ }^{[a]}$

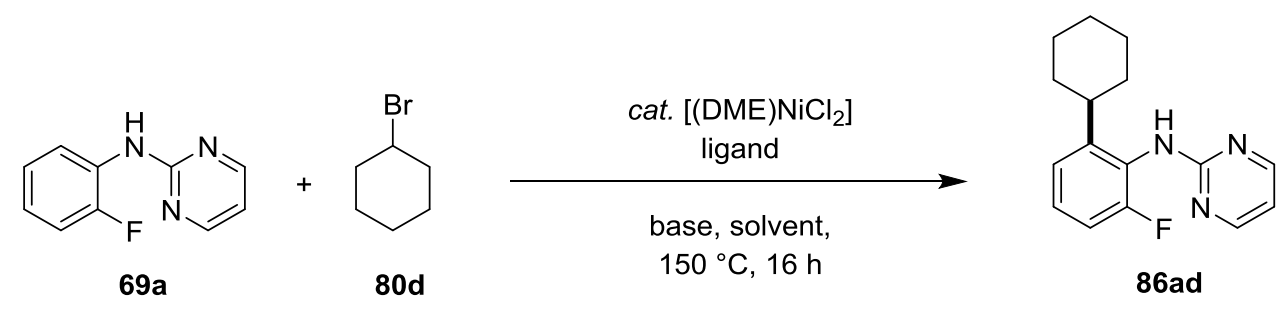

\begin{tabular}{c|c|c|c|c|c}
\hline entry & $\mathrm{Ni}[\mathrm{mol} \%]$ & solvent & ligand (mol \%) & base & yield [\%] \\
\hline 1 & 10 & PhMe & - & LiOtBu & 24 \\
2 & 10 & PhMe & BDMAE (86) (40) & LiOtBu & $94\left(86^{[\mathrm{b}]}\right)$ \\
\hline
\end{tabular}

${ }^{75}$ (a) Korybut-Daszkiewicz, B.; Taraszewska, J.; Zieba, K.; Makal, A.; Wozniak, K. Eur. J. Inorg. Chem. 2004, 33353344. (b) Jarrin, J.; Dawans, F.; Robert, F.; Jeannin, Y. Polyhedron 1982, 1, 409-412.

${ }^{76}$ Musaev, D. G.; Figg, T. M.; Kaledin, A. L. Chem. Soc. Rev. 2014, 43, 5009-5031. 


\begin{tabular}{|c|c|c|c|c|c|}
\hline 3 & 10 & PhMe & TMEDA (108) (40) & LiOtBu & 55 \\
\hline 4 & 2.5 & PhMe & (109) (40) & LiOtBu & 39 \\
\hline 5 & 10 & PhMe & DIPP-NH HN-DIPP (110) (20) & LiOtBu & 15 \\
\hline 6 & 10 & PhMe & $t \mathrm{Bu}-\mathrm{NH} \quad \mathrm{HN}-t \mathrm{Bu}(\mathbf{1 1 1})(20)$ & LiOtBu & 97 \\
\hline 7 & 5 & PhMe & $t \mathrm{Bu}-\mathrm{NH} \quad \mathrm{HN}-t \mathrm{Bu}(111)(10)$ & LiOtBu & 96 \\
\hline 8 & 2.5 & PhMe & $t \mathrm{Bu}-\mathrm{NH} \mathrm{HN}-t \mathrm{Bu}$ (111) (5) & LiOtBu & 81 \\
\hline 9 & 2.5 & PhMe & $\mathrm{HNiPr}_{2}(\mathbf{1 1 2})(10)$ & LiOtBu & 24 \\
\hline 10 & 2.5 & PhMe & TMP (113) (10) & LiOtBu & 15 \\
\hline 11 & 2.5 & 1,4-dioxane & $t \mathrm{Bu}-\mathrm{NH} \mathrm{HN}-t \mathrm{Bu}$ (111) (5) & $\mathrm{LiOtBu}$ & $97\left(95^{[b]}\right)$ \\
\hline 12 & 2.5 & 1,4-dioxane & 12-crown-4 (114) (5) & $\mathrm{LiOtBu}$ & 73 \\
\hline 13 & 2.5 & 1,4-dioxane & $\begin{array}{l}\text { 12-crown-4 (114) (5) + } \\
t \mathrm{Bu}-\mathrm{NH} \mathrm{HN}-t \mathrm{Bu} \text { (111) (5) }\end{array}$ & LiOtBu & 91 \\
\hline 14 & 2.5 & 1,4-dioxane & $t \mathrm{Bu}-\mathrm{NH} \quad \mathrm{HN}-t \mathrm{Bu}$ (111) (5) & $\mathrm{NaOtBu}$ & 2 \\
\hline 15 & 2.5 & 1,4-dioxane & $t \mathrm{Bu}-\mathrm{NH} \mathrm{HN}-t \mathrm{Bu}$ (111) (5) & $\mathrm{KOtBu}$ & 4 \\
\hline 16 & 2.5 & 1,4-dioxane & $t \mathrm{Bu}-\mathrm{NH} \mathrm{HN}-t \mathrm{Bu}(\mathbf{1 1 1})$ & $\mathrm{Mg}(\mathrm{OtBu})_{2}$ & 0 \\
\hline 17 & 2.5 & 1,4-dioxane & $t \mathrm{Bu}-\mathrm{NH} \mathrm{HN}-t \mathrm{Bu}$ (111) (5) & $\mathrm{Li}_{3} \mathrm{PO}_{4}$ & 0 \\
\hline 18 & 1 & 1,4-dioxane & $t \mathrm{Bu}-\mathrm{NH} \mathrm{HN}-t \mathrm{Bu}$ (111) (2) & $\mathrm{LiOtBu}$ & 2 \\
\hline 19 & 0.5 & 1,4-dioxane & $t \mathrm{Bu}-\mathrm{NH} \mathrm{HN}-t \mathrm{Bu}$ (111) (1) & LiOtBu & 1 \\
\hline
\end{tabular}




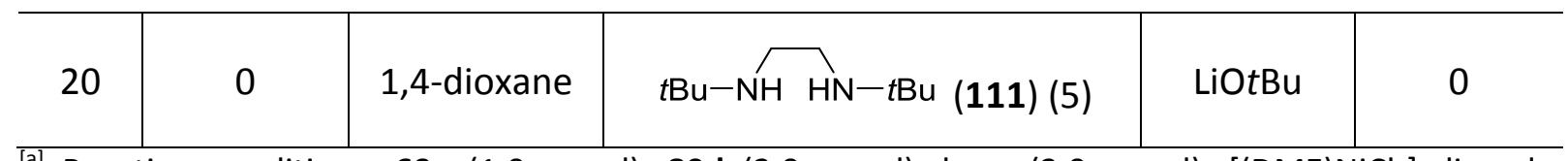

[a] Reaction conditions: 69a $(1.0 \mathrm{mmol}), 80 \mathrm{~d}(2.0 \mathrm{mmol})$, base $(2.0 \mathrm{mmol}),\left[(\mathrm{DME}) \mathrm{NiCl}_{2}\right.$ ], ligand, solvent $(2 \mathrm{~mL}), 150{ }^{\circ} \mathrm{C}, 16 \mathrm{~h}$, yields based on crude ${ }^{19} \mathrm{~F}-\mathrm{NMR}$ with $\mathrm{C}_{6} \mathrm{~F}_{6}$ as internal standard. ${ }^{[\mathrm{b}]}$ Isolated yield.

The catalytic system utilising DtBEDA as the ligand appeared to perform best at reaction temperatures lowered to $100-120^{\circ} \mathrm{C}$ with $80{ }^{\circ} \mathrm{C}$ only giving low conversion (Table 3 , entries 1-3). At these reduced reaction temperatures weaker lithium bases were still not viable for this transformation. Additional ligands consisting of bis-alcohols, oxazolines and primary amines gave no product formation (Table 3, entries $6,8-9$ ). $N$-heterocyclic carbene IPr, however, gave a moderate yield (Table 3, entry 7). Replacing the tert-butyl in DtBEDA with an adamantyl moiety significantly decreased the yield (Table 3, entry 10 ). The previously reported system for primary alkylations with bidentate auxiliaries proved to be ineffective, as well (Table 3, entry 12). Palladium dichloride was tested as the catalyst in order to exclude the possibility of catalytically active trace amount of palladium (Table 3, entry 13). Under these conditions neither the desired product nor other side-products were detected.

Table 3: Optimisation of reaction temperature, base and ligand. ${ }^{[\mathrm{a}]}$

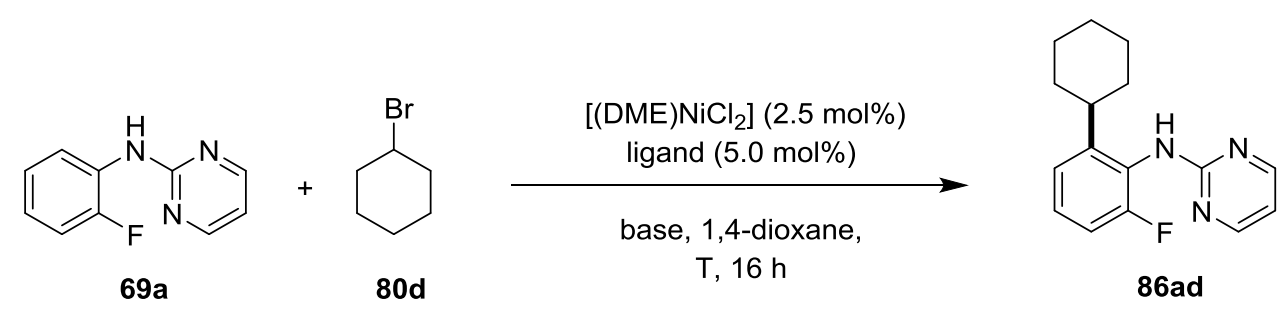

\begin{tabular}{c|c|c|c|c}
\hline entry & $\mathrm{T}\left[{ }^{\circ} \mathrm{C}\right]$ & ligand & base & yield [\%] \\
\hline 1 & 120 & $t \mathrm{Bu}-\mathrm{NH} \mathrm{HN}-t \mathrm{Bu}(\mathbf{1 1 1})$ & LiOtBu \\
2 & 100 & $t \mathrm{Bu}-\mathrm{NH} \mathrm{HN}-t \mathrm{Bu}(\mathbf{1 1 1})$ & $\mathrm{LiOtBu}$ & 98 \\
3 & 80 & $t \mathrm{Bu}-\mathrm{NH} \mathrm{HN}-t \mathrm{Bu}(\mathbf{1 1 1})$ & $\mathrm{LiOtBu}$ & 9 \\
4 & 100 & $t \mathrm{Bu}-\mathrm{NH} \mathrm{HN}-t \mathrm{Bu}(\mathbf{1 1 1})$ & $\mathrm{Li}_{3} \mathrm{PO}_{4}$ & 0 \\
\hline
\end{tabular}




\begin{tabular}{|c|c|c|c|c|}
\hline 5 & 100 & $t \mathrm{Bu}-\mathrm{NH} \mathrm{HN}-t \mathrm{Bu}(\mathbf{1 1 1})$ & $\mathrm{Li}_{2} \mathrm{CO}_{3}$ & 0 \\
\hline 6 & 100 & $\underbrace{\mathrm{HO}}_{\mathrm{Ph}} \mathrm{OH}$ & LiOtBu & 0 \\
\hline 7 & 100 & IPr*HCl (116) & $\mathrm{LiOtBu}$ & 66 \\
\hline 8 & 100 & $\overline{i P r}(117)$ & LiOtBu & 0 \\
\hline 9 & 100 & Ethylene diamine (118) & $\mathrm{LiOtBu}$ & 0 \\
\hline 10 & 100 & 1-Ad-NH HN-1-Ad (119) & LiOtBu & 18 \\
\hline 11 & 100 & $t \mathrm{Bu}-\mathrm{NH} \mathrm{HN}-t \mathrm{Bu}$ (111) & LiOtBu & $99^{[b]}$ \\
\hline 12 & 100 & $\mathrm{PPh}_{3}(120)$ & $\mathrm{LiOtBu}$ & $5^{[c]}$ \\
\hline 13 & 100 & $t \mathrm{Bu}-\mathrm{NH} \mathrm{HN}-t \mathrm{Bu}(111)$ & $\mathrm{LiOtBu}$ & $0^{[\mathrm{d}]}$ \\
\hline
\end{tabular}

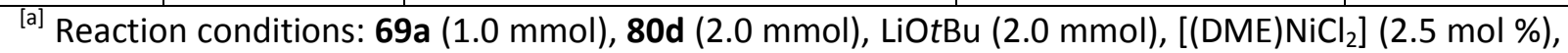
ligand $(5.0 \mathrm{~mol} \%), 1,4$-dioxane $(2 \mathrm{~mL}), 16 \mathrm{~h}$, yields based on crude ${ }^{19} \mathrm{~F}-\mathrm{NMR}$ with $\mathrm{C}_{6} \mathrm{~F}_{6}$ as internal standard. ${ }^{[b]}\left[\mathrm{NiCl}_{2}\left(\mathrm{H}_{2} \mathrm{O}\right)_{6}\right] .{ }^{[\mathrm{c}]} \mathrm{Ni}(\mathrm{OTf})_{2} \cdot{ }^{[\mathrm{d}]} \mathrm{PdCl}_{2}$.

\subsubsection{Scope of C-H Alkylation of anilines}

Due to the novelty of the employed directing group different variations of the basic pattern were examined with the optimised conditions (Scheme 40). Adding an arene substituent on the pyrimidine moiety did not significantly inhibit the reaction to product $\mathbf{1 2 9}$. However, a sideproduct 129' was observed. This observation clearly showed that alternative arrangements of 2-amino-pyrimidines can serve as directing groups as well. Replacing the acidic $\mathrm{N}-\mathrm{H}$ - with a $\mathrm{N}-\mathrm{Me}$ moiety as in compound $\mathbf{1 3 0}$ completely shut down the reaction. $\mathrm{A}$ change of the pyrimidine-moiety to pyridine substrate $\mathbf{1 2 3}$ caused a significant decrease in 
conversion, thereby giving product $\mathbf{1 3 1}$ in trace amounts only. Spatially separating the acidic proton and the directing pyrimidyl group by using $O$-(2-pyrimidyl)-resorcinol 124 led to no conversion. Further, a simpler thiourea-derivative $\mathbf{1 2 5}$ did not give the desired product 133, but instead the S-alkylated product 133'.

Additionally, the catalytic system proved ineffective for $\mathrm{N}$-(2-pyrimidyl)-indole derivatives, which have been previously employed in various $\mathrm{C}-\mathrm{H}$ functionalisations. ${ }^{77}$ Azobenzene 126, which was used by Dubeck and Kleimann very early for the synthesis of the corresponding nickelacycle, was not viable to synthesise $134{ }^{46}$

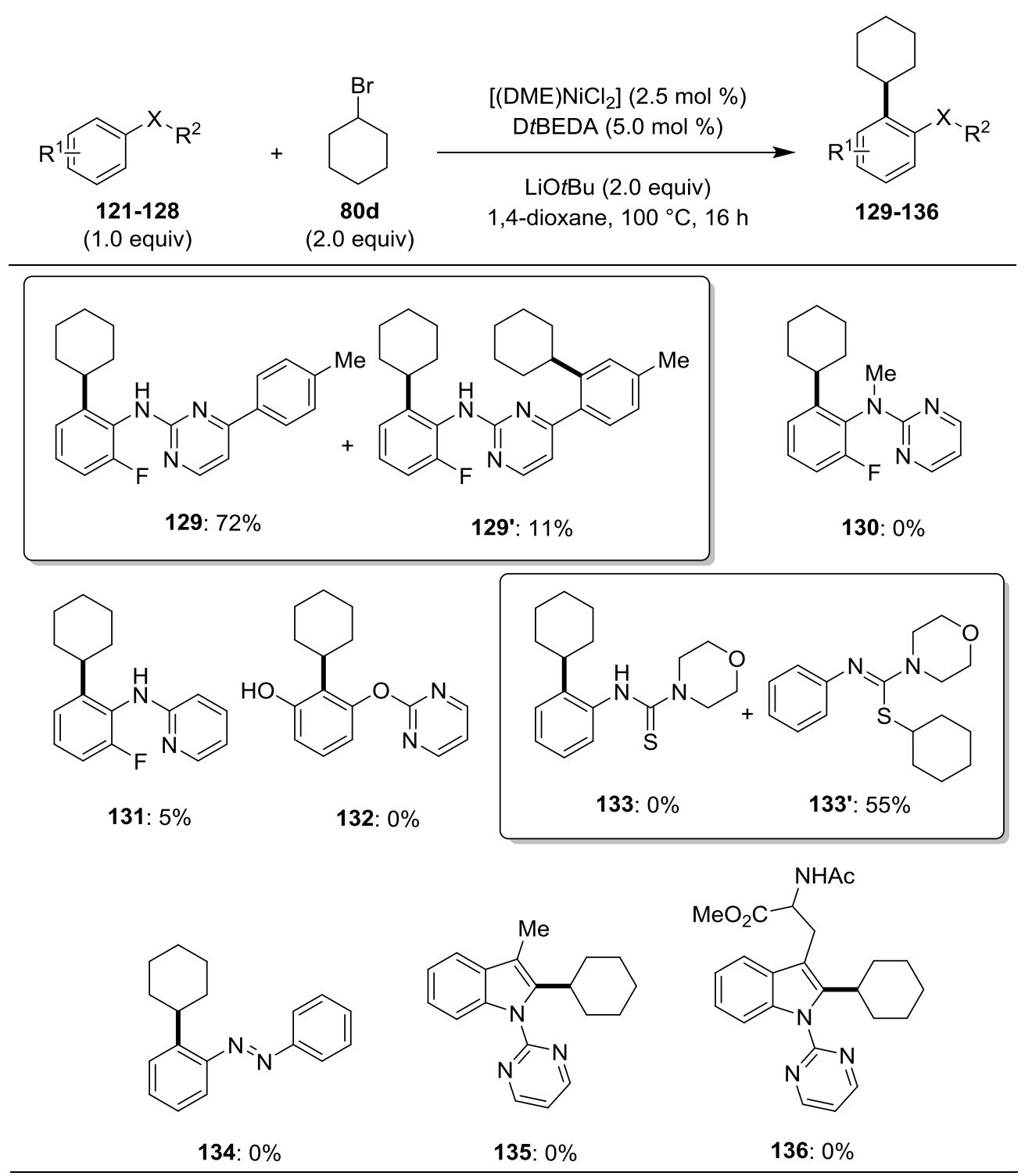

Scheme 40: Scope of C-H alkylations with different directing groups.

\footnotetext{
${ }^{77}$ Selected examples: (a) Sauermann, N.; Gonzalez, M. J.; Ackermann, L. Org. Lett. 2015, 17, 5316-5319. (b) Yoshino, T.; Ikemoto, H.; Matsunaga, S.; Kanai, M. Eur. J. Org. Chem. 2013, 19, 9142-9146. (c) Ackermann, L.; Lygin, A. V. Org. Lett. 2011, 13, 3332-3335.
} 
With the optimised system at hand, a variety of cyclic alkyl bromides $\mathbf{8 0}$ were tested. This was initially done at a reaction temperature of $150{ }^{\circ} \mathrm{C}$ (Scheme 41), as increased temperature usually provided improved efficacy for less reactive halides $\mathbf{8 0}$.

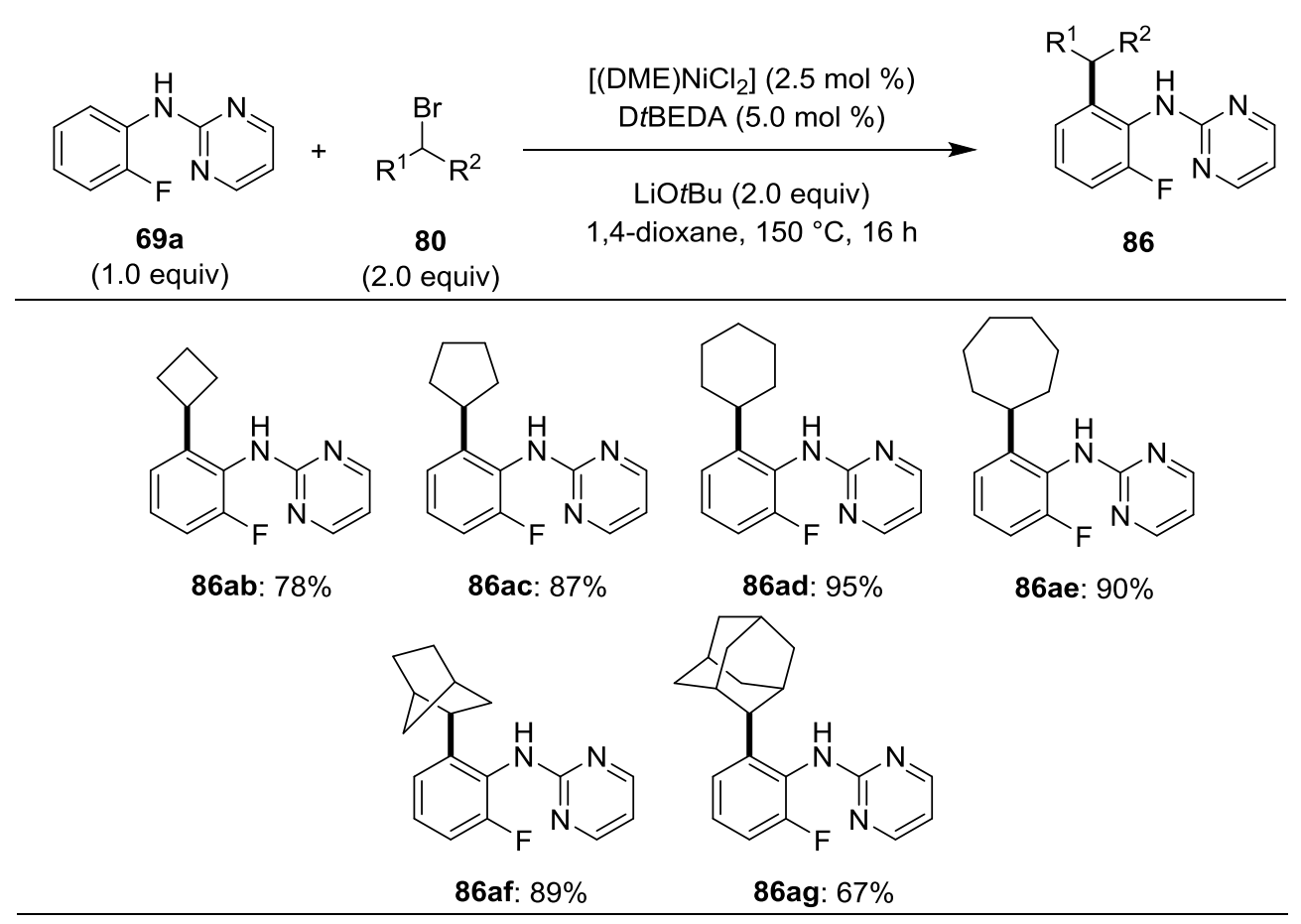

Scheme 41: Scope of C-H alkylation of aniline 69 a with cyclic alkyl bromides 80 at $150^{\circ} \mathrm{C}$.

During further investigation it was found, however, that at reduced reaction temperatures the yields for corresponding cyclic alkyl bromides $\mathbf{8 0}$ was either identical or even better (Scheme 42). Under these reaction conditions a wide range of cyclic alkyl bromides $\mathbf{8 0}$ was well tolerated, with the exception of cyclopropyl bromide 80a. Of particular interest was the use of exo-bromo norbornane $\mathbf{8 0 f}$, which reacted under retention of configuration to give product 86af. The related exo-2-bromo-camphor $80 \mathrm{u}$ on, however, was unreactive, presumably due to the additional keto group. In addition, the bulky 2-bromo adamantane gave 86ag in excellent yields, as well. 


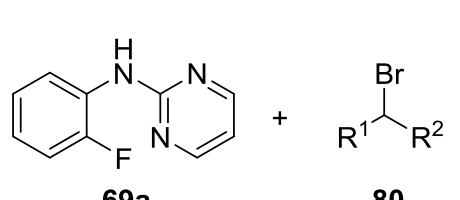

$69 a$ (1.0 equiv) (2.0 equiv)

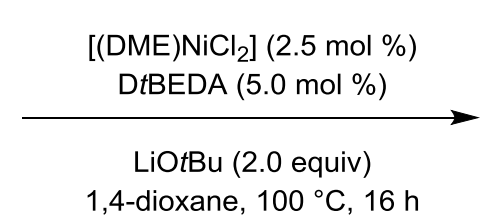

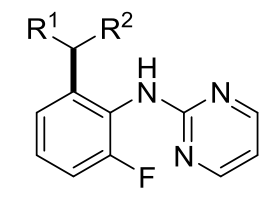

86

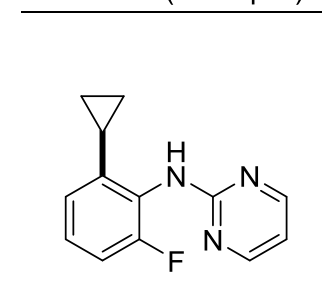

86aa: $0 \%$<smiles>Fc1cccc(C2CCCCCCC2)c1Nc1ncccn1</smiles>

86as: $90 \%$<smiles>Fc1cccc(Nc2ncccn2)c1C1CCC1</smiles>

86ab: $87 \%$

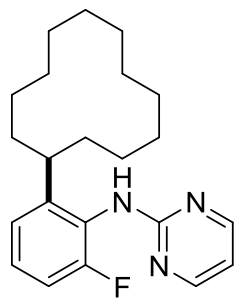

86at: $92 \%$<smiles>Fc1cccc(Nc2ncccn2)c1C1CCCC1</smiles>

86ac: $89 \%$<smiles>Fc1cccc(Nc2ncccn2)c1C1CCCCC1</smiles>

86ad: $98 \%$<smiles>Fc1cccc(Nc2ncccn2)c1C1CCCCCC1</smiles>

86ae: $96 \%$

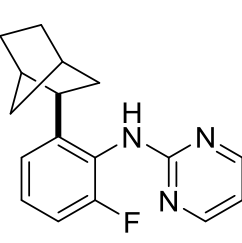

86af: $92 \%$

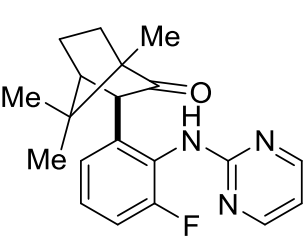

86au: $0 \%$

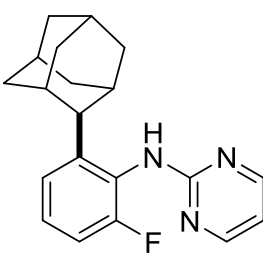

86ag: $87 \%$

Scheme 42: Scope for C-H alkylation of aniline 69a with cyclic alkyl bromides 80 at $100^{\circ} \mathrm{C}$.

The catalytic system was not limited to cyclic alkyl bromides $\mathbf{8 0}$. Acyclic bromides $\mathbf{8 0}$ were also viable substrates (Scheme 43). Alkyl chains containing phthalimide moieties gave excellent yields as well. Esters within the alkyl chain however only led to poor yields of transesterified product 86au'. This is presumably caused by the formation and side reactions of the corresponding ester enolate.

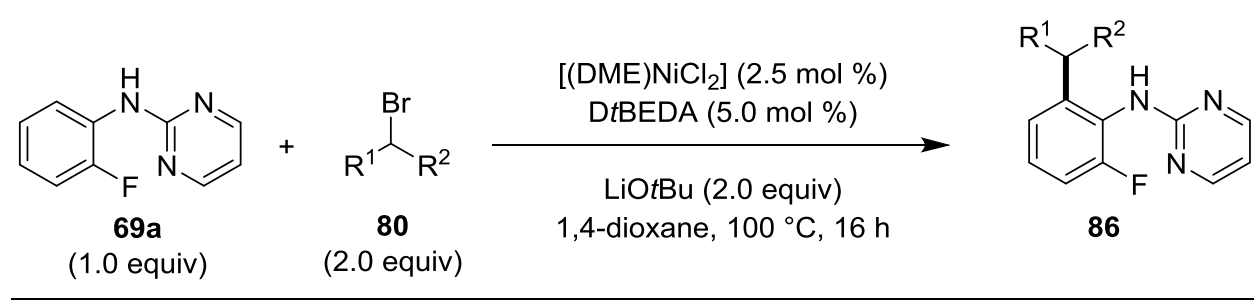<smiles>CC(C)c1cccc(F)c1Nc1ncccn1</smiles>

86ai: $95 \%$<smiles>CC(C)C(c1cccc(F)c1Nc1ncccn1)C(C)C</smiles>

86am: $94 \%$<smiles>CCCCC(C)C(C)Cc1cccc(F)c1Nc1ncccn1</smiles>

86as: $94 \%$<smiles>CCCCC(CCCC)C(CCCC)c1cccc(F)c1Nc1ncccn1</smiles>

86at: $85 \%$<smiles>[R]OC(=O)CCCC(C)c1cccc(F)c1Nc1ncccn1</smiles>

86au: $0 \%(R=M e)$ 86au': $7 \%(R=t B u)$<smiles>CC(CCCNc1ccccc1)c1cccc(F)c1Nc1ncccn1</smiles>

86ap: $80 \%$

Scheme 43: Scope for C-H alkylation aniline 69a with acyclic alkyl bromides 80 at $100{ }^{\circ} \mathrm{C}$. 
Additionally, several differently decorated arenes 69 were investigated (Scheme 44). With substrates $69 \mathrm{~h}-\mathrm{j}$, in which the ortho-position is unsubstituted, good selectivity for the monoalkylated products with moderate yields can be achieved by lowering the amount of alkyl bromide 80 to 1.1 equivalents. For substrates $69 \mathrm{i}$-j bearing a fluoro-substituent in the metaposition yields decreased significantly. This might be attributed to either additional coordination of the fluoro-group towards the nickel-catalyst or potential $\mathrm{C}-\mathrm{F}$ activation by the nickel-catalyst.

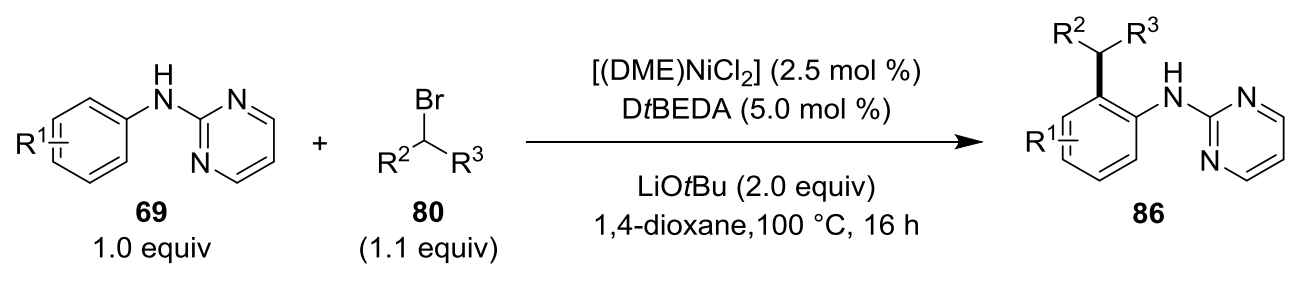<smiles>c1cnc(Nc2ccccc2C2CCCCC2)nc1</smiles>

86hd: $54 \%^{[\mathrm{b}]}\left(13 \%{ }^{[\mathrm{a}, \mathrm{b}]}\right)$<smiles>Fc1cc(Nc2ncccn2)c(C2CCCCC2)c(F)c1F</smiles>

86id: $6 \%$<smiles>Fc1ccc(C2CCCCC2)c(Nc2ncccn2)c1</smiles>

86jd: $26 \%\left(19 \%^{\mathrm{a}}\right)$<smiles>CCCCC(CCCC)c1ccccc1Nc1ncccn1</smiles>

86ht: $60 \%$<smiles>[Z20]c1ccccc1Nc1ncccn1</smiles>

86hg: $55 \%$

${ }^{\text {[a] }}$ yield of bis-alkylated product. ${ }^{[b]} 3.5 \mathrm{mmol}$ scale.

Scheme 44: Scope for C-H alkylation of anilines 69 with alkyl bromides 80 at $120^{\circ} \mathrm{C}$.

It was shown during the previous optimisation studies (Table 3, entry 11), that the benchstable Nickel dichloride hexahydrate appeared to be an efficient catalyst also. Therefore, a small selection of substrates was tested for these conditions (Scheme 45). It was found that for most substrates the conversion was lower, yet still acceptable.

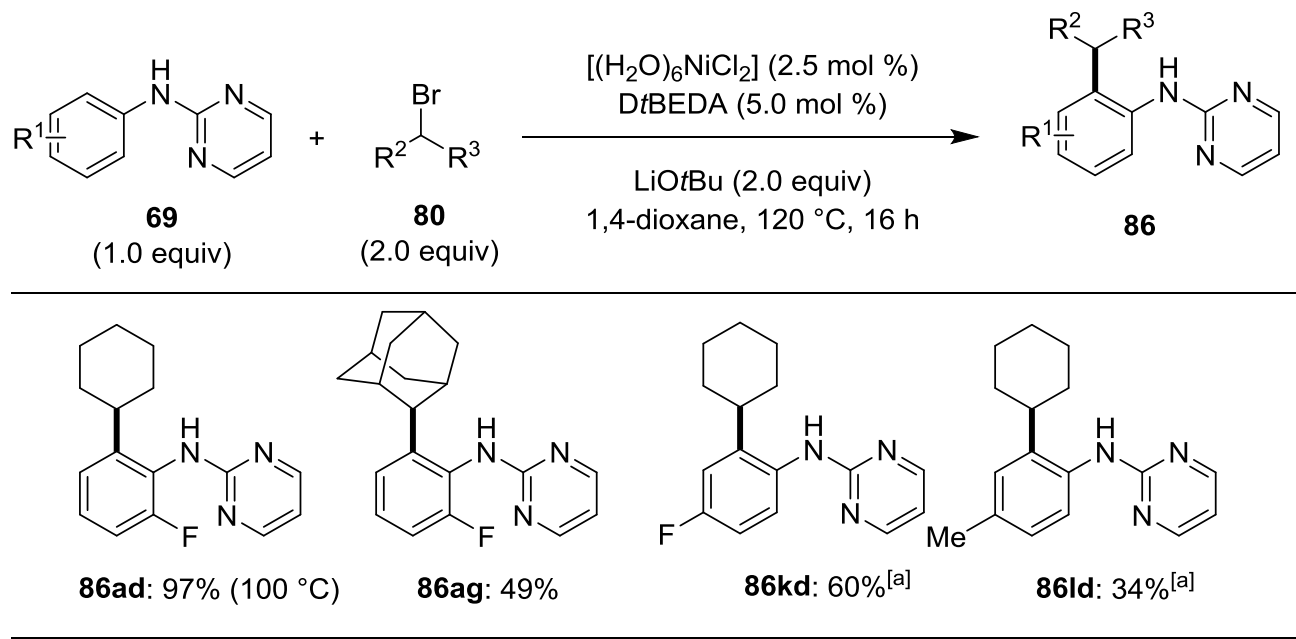

[a] 1.1 equiv of $\mathbf{8 0 d}$ used.

Scheme 45: Scope for $\mathrm{C}-\mathrm{H}$ secondary alkylation with $\left[\mathrm{NiCl}_{2}\left(\mathrm{H}_{2} \mathrm{O}\right)_{6}\right]$ as the catalyst. 
In case of benzylic bromides $\mathbf{8 0 0 / v}$ a change in chemo-selectivity to $\mathrm{N}$-alkylation was observed (Scheme 46).

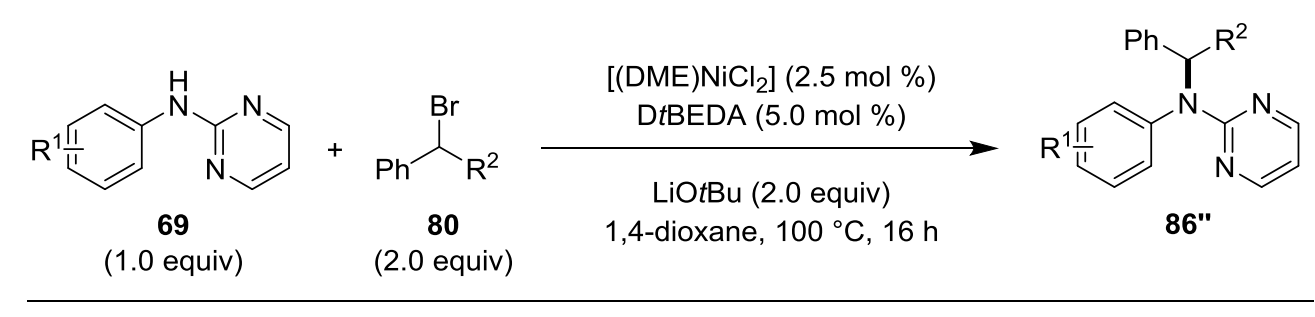<smiles>CC(c1ccccc1)N(c1ncccn1)c1ccccc1F</smiles><smiles>Fc1ccccc1N(c1ccccc1)c1ncccn1</smiles><smiles>CC(c1ccccc1)N(c1ccccc1)c1ncccn1</smiles>

86av": $84 \%$

86ao": $77 \%$

86hv": $57 \%$

Scheme 46: $N$-Benzylation with alkyl bromides $80 \mathrm{v} / 0$.

In addition to alkyl halides the more easily accessible cyclohexyl acetate (137) was probed (Scheme 47). However, the current catalytic system proved inefficient for this type of substrates.<smiles>Fc1ccccc1Nc1ncccn1</smiles>

$69 \mathrm{a}$

(1.0 equiv)

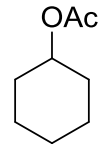

137 (2.0 equiv)

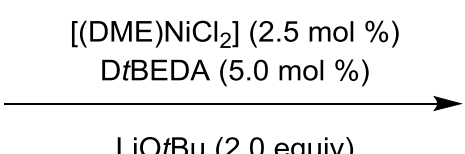

LiOtBu (2.0 equiv)

1,4-dioxane, $100{ }^{\circ} \mathrm{C}, 16 \mathrm{~h}$

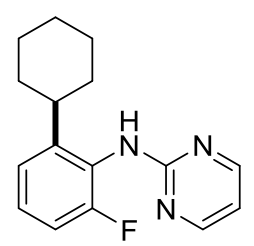

86ad: $0 \%$

Scheme 47: Attempted C-H alkylation of aniline 68a with cyclohexyl acetate (137).

\subsubsection{Mechanistic Studies}

Intrigued by this unusual, new transformation a variety of mechanistic studies was conducted. First, isotopically labelled substrate $D_{5}-69 \mathrm{~h}$ was subjected to the reaction conditions with only the standard ligand DtBEDA as a proton source, giving significant H/Dexchange (Scheme 48). This result shows that in the absence of alkyl halides 80 the $\mathrm{C}-\mathrm{H}$ metalation is facile. 


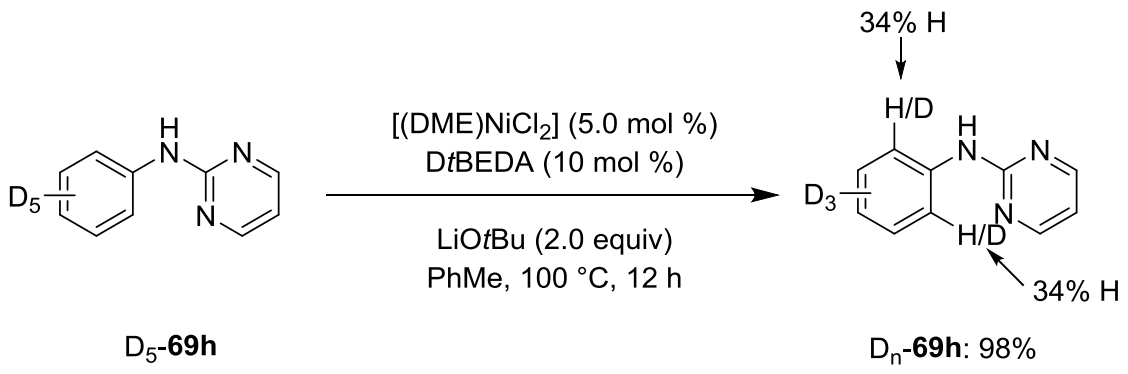

Scheme 48: H/D-exchange for substrate $D_{5}-69 d$ with DtBEDA as proton source.

The reverse process, using $69 \mathrm{~h}$ in the presence of $D_{4}$-methanol led to no H/D-exchange (Scheme 49). This, however, may be attributed to the significantly more acidic deuterium donor, thus changing the reaction conditions greatly, thus making them incompatible with the catalytic system.

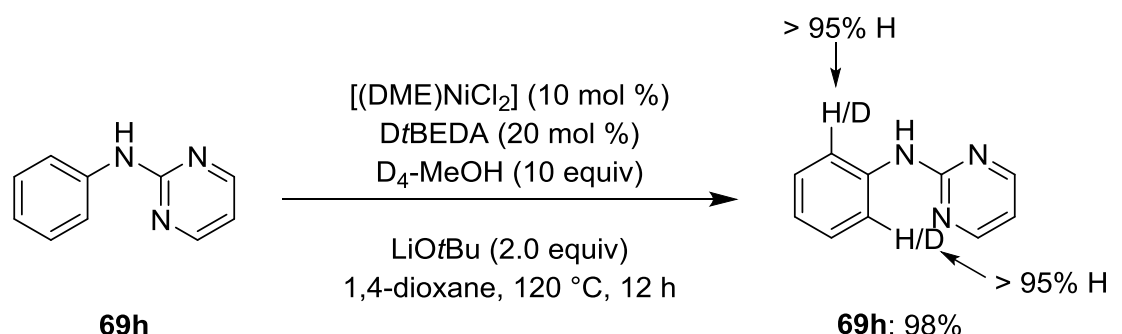

Scheme 49: Attempted H/D-exchange for $69 \mathrm{~h}$ with $\mathrm{D}_{4}-\mathrm{MeOH}$ as deuterium source.

The reaction of labelled substrate $D_{5}-69 \mathrm{~h}$ with alkyl halide $80 \mathrm{~d}$ showed significant $H / D$ scrambling (Scheme 50). Considering these findings it can be assumed that the $\mathrm{C}-\mathrm{H}-$ metalation is reversible.

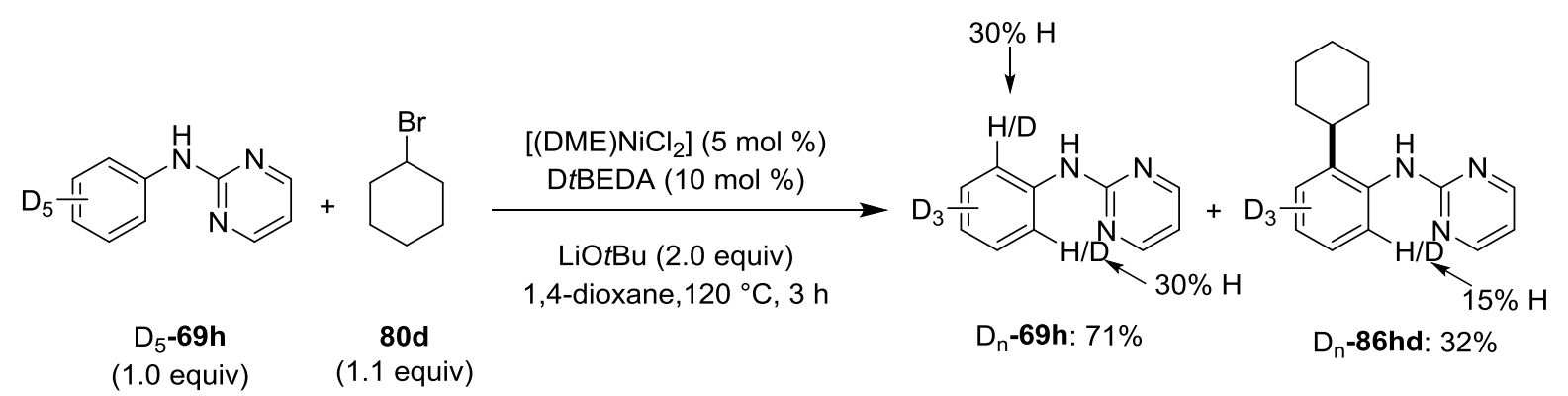

Scheme 50: H/D-exchange under standard reaction conditions.

Independent experiments with substrates $69 \mathrm{~h}$ and $D_{5}-69 \mathrm{~h}$ with alkylation $80 \mathrm{~d}$ revealed a kinetic isotope effect (KIE) of $k_{H} / k_{D}=1.7$ (Scheme 51). A kinetic isotope effect (KIE) of this magnitude might indicate that the $\mathrm{C}-\mathrm{H}$ metalation is not the rate determining step. 

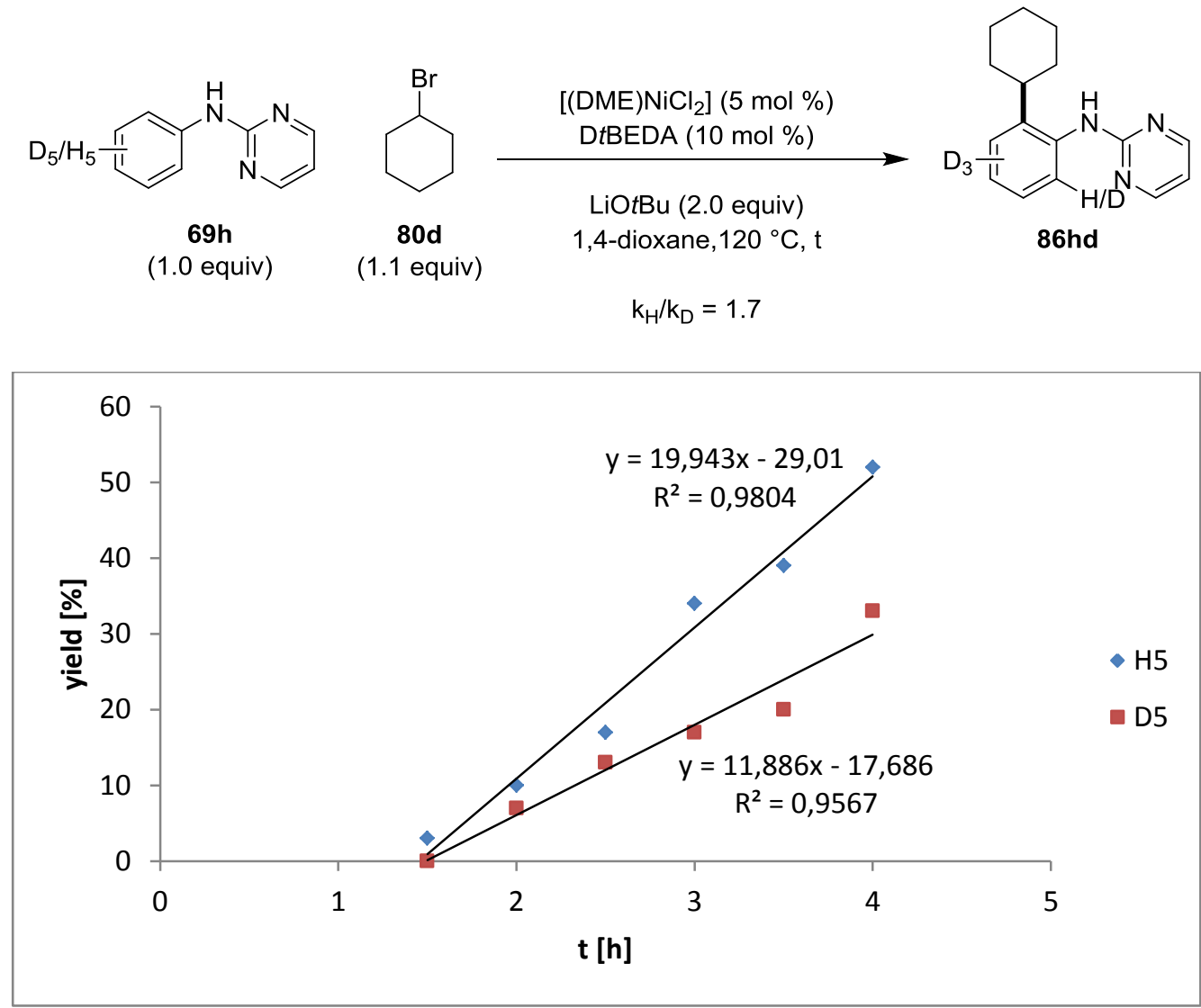

Scheme 51: Kinetic isotope effect studies.

Considering that the alkyl halides $\mathbf{8 0}$ may undergo elimination to the corresponding olefins, the actual alkylation agent should be identified. For this the standard reaction was attempted with cyclohexene 138 under otherwise identical reaction conditions (Scheme 52).

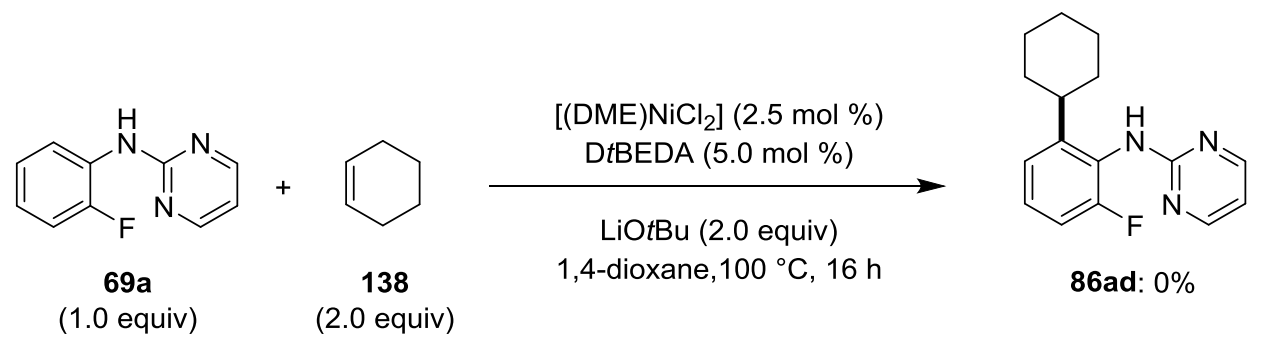

Scheme 52: Attempted alkylation of substrate 69a with cyclohexene 138.

Likewise, the more reactive styrene 139 (Scheme 53) did not yield any alkylated products. It can therefore be concluded that the alkyl halides $\mathbf{8 0}$ are the active alkylating agents.

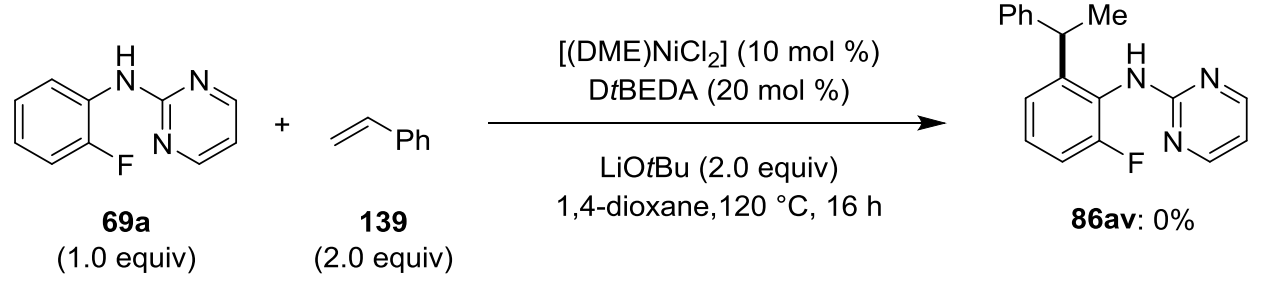

Scheme 53: Attempted alkylation of substrate 69a with styrene 139. 
To probe the mode of the alkyl bromide activation a reaction was performed in the presence of the radical scavenger TEMPO (Scheme 54). This led to a shutdown of the catalytic reactivity, indicating formation of radical intermediates.
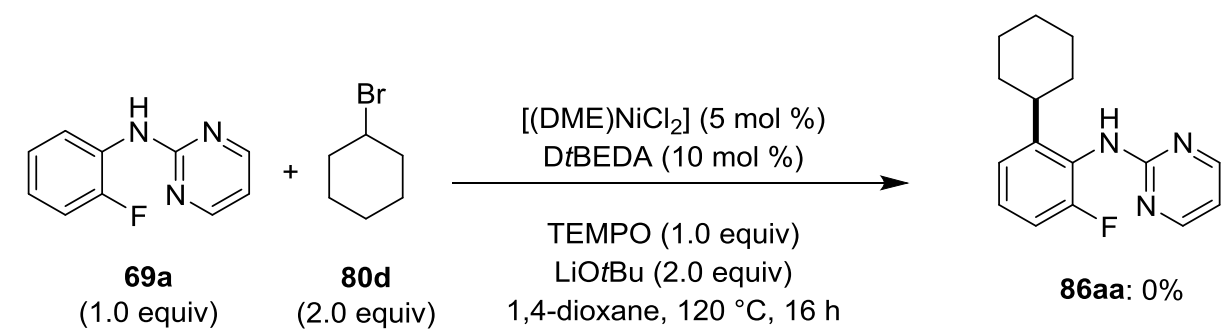

Scheme 54: Standard reaction in presence of radical scavenger TEMPO. ${ }^{78}$

The enantiopure alkyl halide (S)-80k lead to full racemization in the product 86ak, further indicating a planar, radical intermediate (Scheme 55).
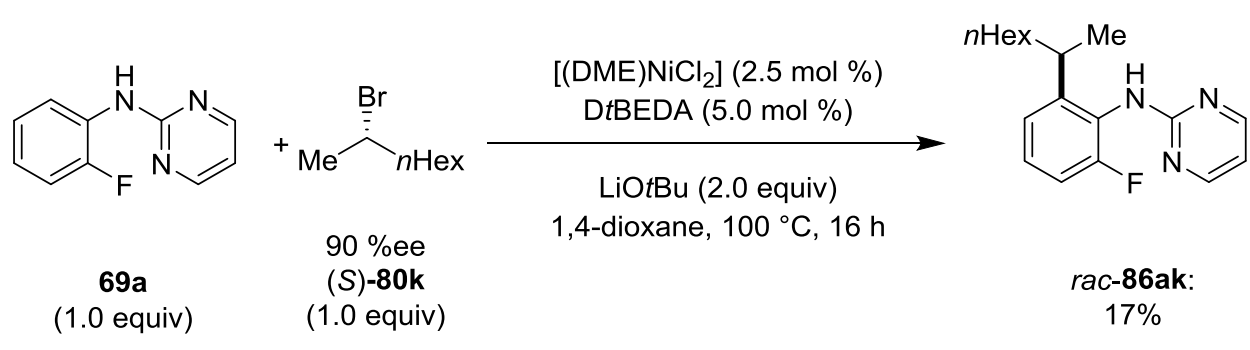

Scheme 55: Standard reaction with enantiopure (S)-2-bromo-octane ((S)-80k).

In order to elucidate electronic effects on the $\mathrm{C}-\mathrm{H}$ alkylation, a Hammett plot was done (Scheme 56). Here, a clear positive inclination towards high sigma-values was observed, albeit a possibly unusual change in steepness at values near 0 . This result can indicate for the reductive elimination to be rate determining. A few additional factors, however, should be taken into account. The most basic fact is that the Hammott correlation was developed for reactions that undergo a clean reaction not creating side-products, while also using substrates whose substituents do not cause secondary effects on the reaction kinetics. ${ }^{79}$ These criteria may not fully apply in the case given here. For one, substrates containing $C-F$ and $\mathrm{C}-\mathrm{Cl}$ bonds may, to some degree, undergo side reactions involving these bonds. This may influence the rate of the corresponding reaction. Another secondary effect to be regarded here is the acidity of the $\mathrm{N}-\mathrm{H}$ group. This moiety has previously been shown to be vital. The acidity should increase towards more positive sigma-values. Therefore, if said acidity may become relevant for the rate of the reaction, it may explain the observed change in inclination. Thus, for a more clear answer a significantly larger set of data points or a separate correlation between acidity and reaction rate will be required.

\footnotetext{
${ }^{78}$ Experiment performed by Zhixiong Ruan.

${ }^{79}$ (a) Hansch, C.; Leo, A.; Taft, R. W. Chem. Rev. 1991, 91, 165-195. (b) Hammett, L. P. J. Am. Chem. Soc. 1937, 59, 96-103.
} 

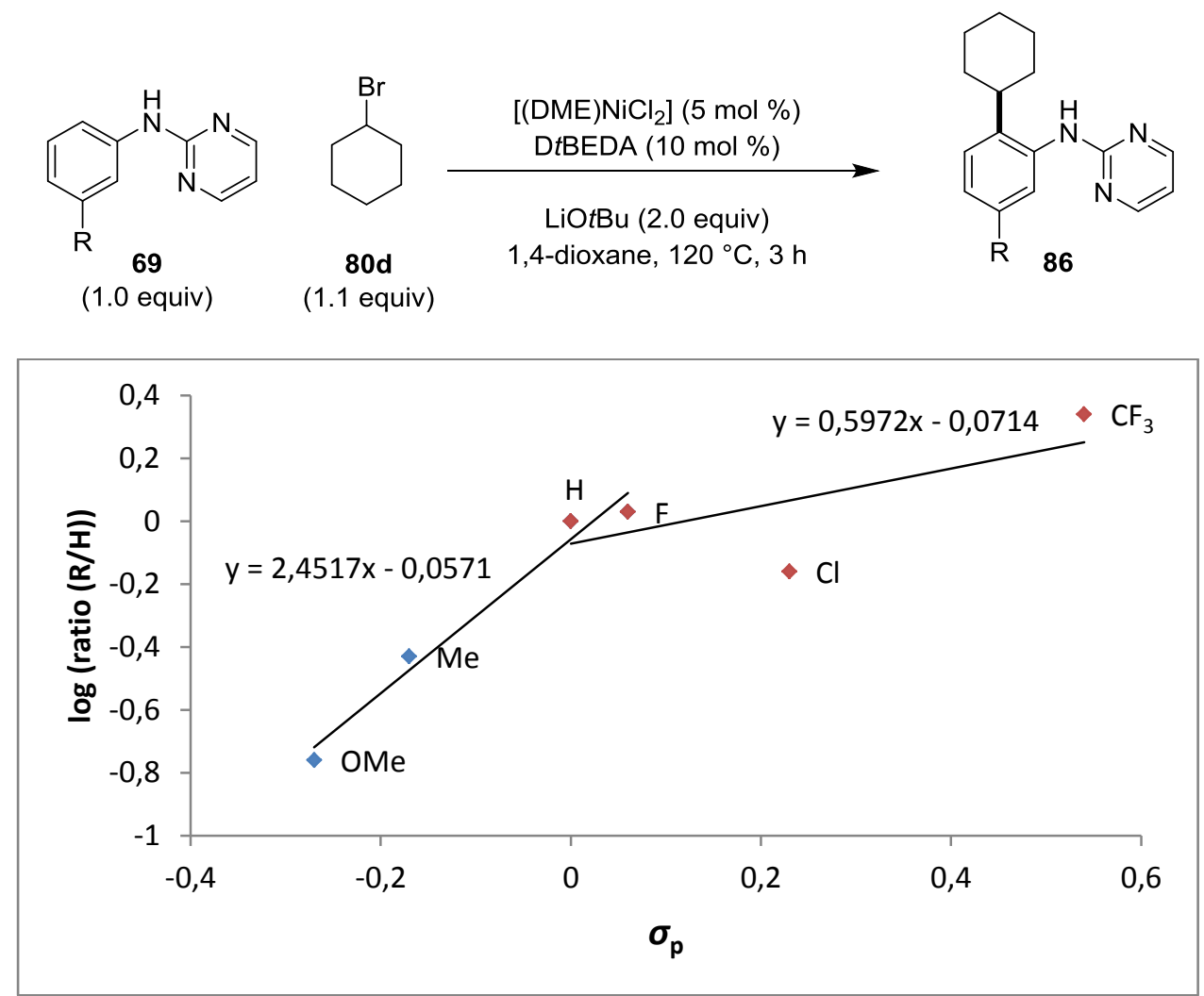

Scheme 56: Hammett plot for C-H secondary alkylation of anilines 69.

Considering the novelty of the employed directing group, studies regarding the nickelacycle were conducted. The assumed cycle is six-membered based on previous findings for palladium, ${ }^{80}$ ruthenium $^{81}$ and gold complexes. ${ }^{82}$ Initially an oxidative addition of $\mathrm{Ni}(0)$ with ortho-Bromo-substrate 69q was attempted (Scheme 57). While the crude analysis indicated formation of traces of several new compounds, the assumed nickelacycle $\mathbf{1 4 0}$ could not be identified via crude NMR analysis or isolated.<smiles>Fc1cccc(Br)c1Nc1ncccn1</smiles>

$69 q$

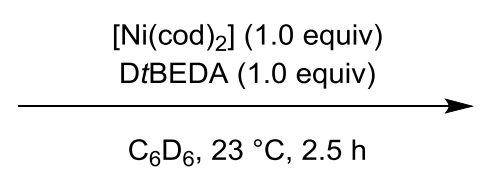

$\mathrm{C}_{6} \mathrm{D}_{6}, 23{ }^{\circ} \mathrm{C}, 2.5 \mathrm{~h}$

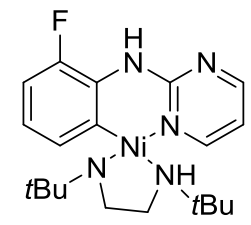

140: $0 \%$

Scheme 57: Attempted synthesis of nickelacycle 140 through oxidative addition.

Another approach was simply applying the reported procedure for the palladacycle (Scheme 58). Crude NMR analysis indicated only simple coordination of the lewis basic nitrogen of the directing group to the nickel ion.

\footnotetext{
${ }^{80}$ Nonoyama, M. Transition Met. Chem. 1982, 7, 281-284.

${ }^{81}$ Nonoyama, M. Polyhedron 1985, 4, 765-768.

${ }^{82}$ Nonoyama, M.; Nakajima, K.; Nonoyama, K. Polyhedron 1997, 16, 4039-4044.
} 
(a)<smiles>Fc1ccccc1Nc1ncccn1</smiles>

$69 a$

(b)<smiles>Fc1ccccc1Nc1ccccn1</smiles>

$123 a$
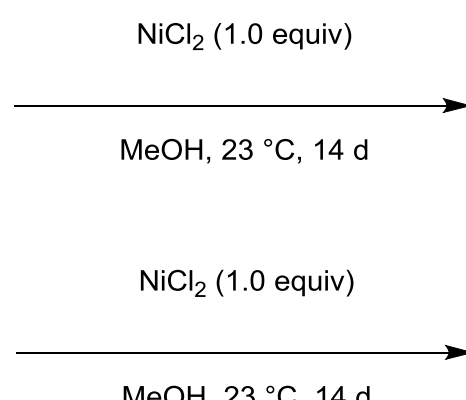

$\mathrm{MeOH}, 23^{\circ} \mathrm{C}, 14 \mathrm{~d}$<smiles></smiles>

141: $0 \%$<smiles></smiles>

142: $0 \%$

Scheme 58: Attempted formation of nickelacycle through $\mathrm{C}-\mathrm{H}$ metalation.

Based on our mechanistic studies a catalytic cycle can be proposed (Scheme 59). The catalytic cycle is initiated by deprotonation of substrate 69 , followed by $\mathrm{C}-\mathrm{H}$-metallation by the nickel catalyst. Based on the mechanisms previously discussed (Scheme 10) and the electron-rich nature of the aniline substrates used, it can be considered for a intramolecular electrophilic substitution (IES) mechanism to be most probable. However, a ambiphilic metal ligand activation (AMLA) pathway should also be considered. The following oxidative addition occurs in two steps through an SET-pathway. In this the bromide reacts first with the metal centre, followed by a rebound of the organic radical to generate nickel species $\mathbf{1 4 0}$. Last, reductive elimination leads to the desired product $\mathbf{8 6}$ and regeneration of the nickel catalyst.

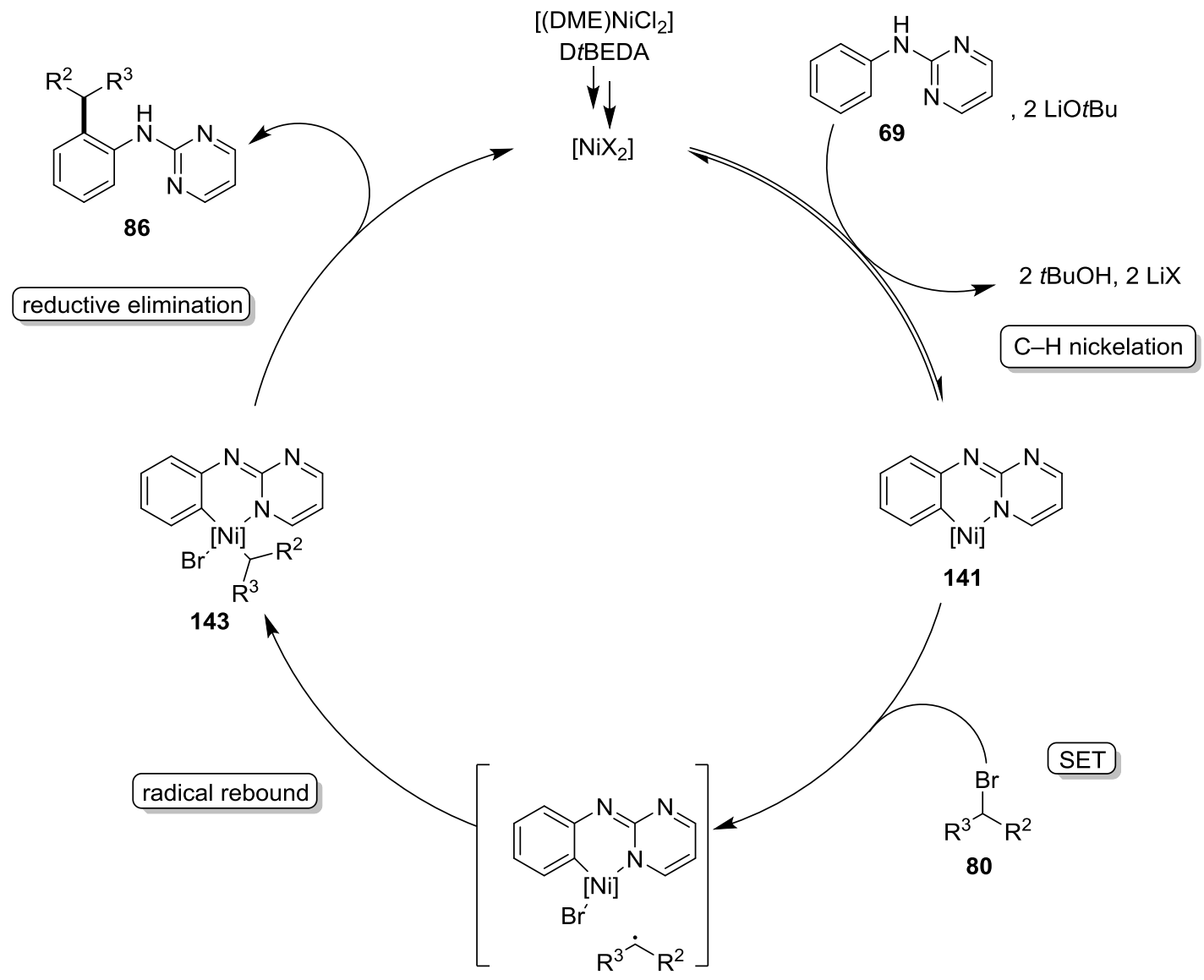

Scheme 59: Proposed catalytic cycle for the direct secondary alkylation of anilines 69. 


\subsection{Direct C-H Fluoroalkylation of $\mathbf{N}$-Pyrimidyl-Anilines}

Introducing fluorine or fluorine-containing functional groups into organic compounds is crucial within medicinal chemistry. In connection with the importance of the 2-aminopyrimidine moiety in anti-cancer drugs, trifluoroethylation was attempted with the $\mathrm{N}$-(2pyrimidyl)-aniline substrate 69 as well.

\subsubsection{Synthesis of Starting Materials}

For substrate 146 a novel synthesis was developed. This became necessary due to the only reported procedures either requiring expensive reagents or special autoclave techniques. ${ }^{83}$ Therefore, derived from these procedures, a synthesis starting from commercially available trifluoroethanol 144 was devised (Scheme 60). After tosylation of the alcohol to give trifluoroethyltosylate 145 , substitution with sodium bromide at high temperatures gave the desired reagent 146.

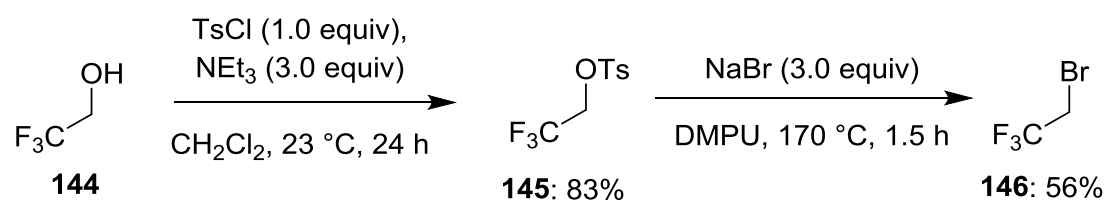

Scheme 60: Synthesis of trifluoroethyl bromide 146.

\subsubsection{Optimisation Studies}

At the outset, the envisioned $\mathrm{C}-\mathrm{H}$ trifluoroethylation for standard substrate $69 \mathrm{~b}$ and commercially available trifluoroethyl iodide $\mathbf{8 2}$ were tested without ligand and these conditions furnished minor amounts of the desired product $\mathbf{8 7 b}$ (Table 4, entry 1). Employing the BDMAE ligand, which has previously been used for the analogous trifluoroethylation reaction under bidentate assistance, a significant improvement was observed (Table 4, entry 2). Lowering the reaction temperature reduced the conversion notably (Table 4, entries 35). Similar to previous finding, use of weaker bases completely shut down the efficacy of the catalytic system (Table 4, entries 6-10).

\footnotetext{
${ }^{83}$ (a) Mathey, F. 2001, Molybdenum(VI) Fluoride. e-EROS Encyclopedia of Reagents for Organic Synthesis. (b) Kashutina, E. V.; Lavrent'ev, A. N. Zhurnal Obshchei Khimii 2000, 70, 1814.
} 
Table 4: Screening of solvents and bases for $\mathrm{C}-\mathrm{H}$ trifluoroethylation of aniline $69 \mathrm{~b} .^{[a]}$

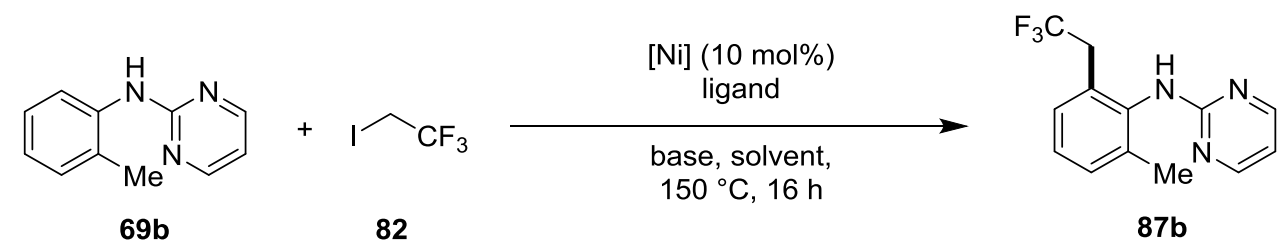

\begin{tabular}{|c|c|c|c|c|c|}
\hline entry & {$[\mathrm{Ni}]$} & ligand [mol \%] & solvent & base & yield [\%] \\
\hline 1 & [(DME) $\left.\mathrm{NiCl}_{2}\right]$ & - & PhMe & LiOtBu & $<10$ \\
\hline 2 & {$\left[(\mathrm{DME}) \mathrm{NiCl}_{2}\right]$} & BDMAE (89) (40) & PhMe & LiOtBu & 83 \\
\hline 3 & {$\left[(\mathrm{DME}) \mathrm{NiCl}_{2}\right]$} & BDMAE (89) (40) & PhMe & LiOtBu & $-\left(<30^{[b, c]}\right)$ \\
\hline 4 & {$\left[(\mathrm{DME}) \mathrm{NiCl}_{2}\right]$} & BDMAE (89) (40) & $\mathrm{PhH}$ & LiOtBu & $53^{[c]}$ \\
\hline 5 & {$\left[(\mathrm{DME}) \mathrm{NiCl}_{2}\right]$} & BDMAE (89) (40) & PhMe & $\mathrm{LiOtBu}$ & $69^{[\mathrm{d}]}$ \\
\hline 6 & {$\left[(\mathrm{DME}) \mathrm{NiCl}_{2}\right]$} & BDMAE (89) (40) & $\begin{array}{c}\mathrm{PhMe} / \mathrm{tBuOH} \\
(19: 1)\end{array}$ & $\mathrm{Na}_{2} \mathrm{CO}_{3}$ & 0 \\
\hline 7 & {$\left[(\mathrm{DME}) \mathrm{NiCl}_{2}\right]$} & BDMAE (89) (40) & $\begin{array}{c}\mathrm{PhMe} / \mathrm{tBuOH} \\
(19: 1)\end{array}$ & $\mathrm{Li}_{2} \mathrm{CO}_{3}$ & 0 \\
\hline 8 & {$\left[(\mathrm{DME}) \mathrm{NiCl}_{2}\right]$} & BDMAE (89) (40) & PhMe & $\begin{array}{c}\mathrm{Na}_{2} \mathrm{CO}_{3} / \mathrm{LiBr} \\
(1.0)\end{array}$ & 0 \\
\hline 9 & [(diglyme) $\mathrm{NiBr}_{2}$ ] & BDMAE (89) (40) & PhMe & $\mathrm{Na}_{2} \mathrm{CO}_{3}$ & 0 \\
\hline 10 & [(diglyme) $\mathrm{NiBr}_{2}$ ] & BDMAE (89) (40) & PhMe & $\mathrm{NaOAC}$ & 0 \\
\hline
\end{tabular}

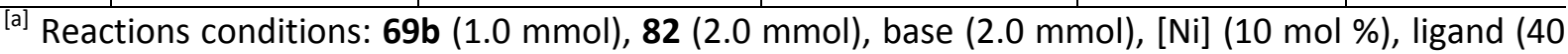
mol \%), solvent $(2 \mathrm{~mL}), 150{ }^{\circ} \mathrm{C}, 16 \mathrm{~h}$, yields based on crude ${ }^{19} \mathrm{~F}-\mathrm{NMR}$ with $\mathrm{C}_{6} \mathrm{~F}_{6}$ as internal standard. ${ }^{[\mathrm{b}]}$ Isolated yield. ${ }^{[c]} 120^{\circ} \mathrm{C} .{ }^{[d]} 130^{\circ} \mathrm{C}$.

Further screening of ligands revealed that other tertiary amines 108 or pyridine 147 derivatives are not viable for this transformation (Table 5, entries 1 and 2). Similarily, phosphine-, carbene- and phenol-ligands performed poorly (Table 5, entries 3-6). 
Table 5: Screening of ligands for the trifluoroethylation of aniline $69 \mathrm{~b} .^{\text {[a] }}$
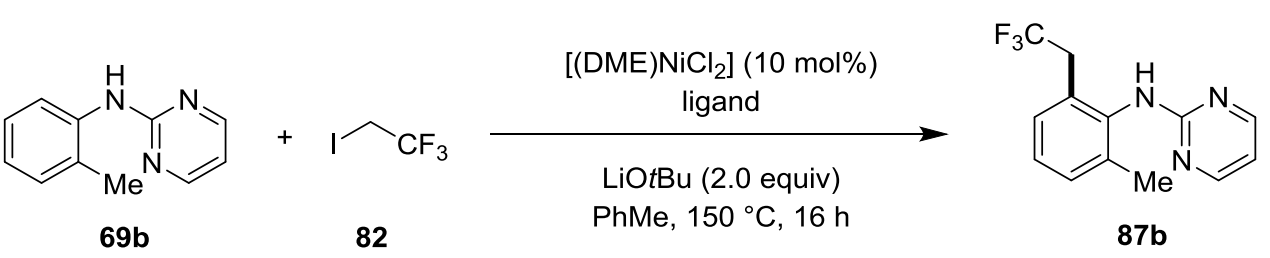

\begin{tabular}{c|c|c}
\hline entry & ligand [mol \%] & yield [\%] \\
\hline 1 & BDMAE (89) (40) & 83 \\
2 & TMEDA (108) (40) & 14 \\
3 & 2,2'-bipyridine (147) (10) & 11 \\
4 & $(R)$-BINOL (100) (10) & $<5$ \\
5 & PPh $_{3}(\mathbf{1 2 0})(40)$ & $<10$ \\
6 & XantPhos (148) (20) $_{7}$ & 21 \\
7 & IPr HCl (116) (10) $_{8}$ & $<5$ \\
8 & $\operatorname{LiCP}^{*}(\mathbf{1 4 9})(10)$ & $<5$ \\
\hline
\end{tabular}

${ }^{\text {[a] }}$ Reactions conditions: $69 \overline{\mathrm{b}(1.0 \mathrm{mmol}), 82(2.0 \mathrm{mmol}), \text { LiOtBu }(2.0 \mathrm{mmol}), \mathrm{PhMe}}(2 \mathrm{~mL}), 150{ }^{\circ} \mathrm{C}, 16 \mathrm{~h}$, yields based on crude ${ }^{19} \mathrm{~F}-\mathrm{NMR}$ with $\mathrm{C}_{6} \mathrm{~F}_{6}$ as internal standard. ${ }^{[b]}$ Isolated yield.

Considering the high efficacy of the DtBEDA ligand in the secondary alkylation of anilines 69, this system was also tested for the $\mathrm{C}-\mathrm{H}$ trifluoroethylation (Table 6). Initially, only moderate yields were achieved, however at significantly lower reaction temperatures (Table 6, entries $1-3$ ). Changing the solvent to arenes gave either lower or, at best, identical yields (Table 6, entries 4-7). When a wider variety of ether solvents was tested, 2-methyl-tetrahydrofuran was found to be optimal (Table 6, entries 10-16).

Table 6: Solvent effect for C-H trifluoroethylation with DtBEDA ligand. ${ }^{\text {[a] }}$<smiles>Cc1ccccc1Nc1cnccn1</smiles>

$69 \mathrm{~b}$

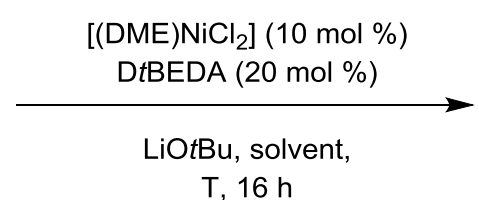

82<smiles>[X]c1cccc(CC(F)(F)F)c1Nc1ncccn1</smiles>

$87 \mathrm{~b}$

\begin{tabular}{c|c|c|c}
\hline entry & $\mathrm{T}\left[{ }^{\circ} \mathrm{C}\right]$ & solvent & yield [\%] \\
\hline 1 & 140 & 1,4-dioxane & 38 \\
2 & 120 & 1,4-dioxane & 44 \\
3 & 100 & 1,4-dioxane & 26 \\
4 & 120 & $\mathrm{PhMe}$ & 19 \\
5 & 120 & $\mathrm{PhtBu}$ & 26 \\
6 & 120 & $\mathrm{PhCl}$ & 43 \\
7 & 120 & $\mathrm{PhCF}_{3}$ & 18 \\
8 & 120 & 1,4-dioxane & $11^{[\mathrm{b}]}$ \\
9 & 120 & 1,4-dioxane & $3^{[\mathrm{c}]}$ \\
\hline
\end{tabular}




\begin{tabular}{c|c|c|c}
\hline 10 & 120 & $\mathrm{DME}$ & 14 \\
11 & 120 & $(\mathrm{nBu})_{2} \mathrm{O}$ & 0 \\
12 & 120 & $\mathrm{THF}$ & 39 \\
13 & 120 & $\mathrm{PhOMe}$ & 15 \\
14 & 120 & $\mathrm{Ph}_{2} \mathrm{O}$ & 9 \\
15 & 120 & $\mathrm{CPME}$ & 4 \\
16 & 120 & 2-Me-THF & 47 \\
\hline
\end{tabular}

${ }^{[a]}$ Reactions conditions: $69 \mathrm{~b}(1.0 \mathrm{mmol}), 82(2.0 \mathrm{mmol})$, LiOtBu $(2.0 \mathrm{mmol})$, solvent $(2 \mathrm{~mL}), 150{ }^{\circ} \mathrm{C}, 16$ $\mathrm{h}$, yields based on crude ${ }^{19} \mathrm{~F}-\mathrm{NMR}$ with $\mathrm{C}_{6} \mathrm{~F}_{6}$ as internal standard. ${ }^{[b]} \mathrm{LiBr}$ (2.0 equiv). ${ }^{\text {[c] }}$ DMEDA (20 mol \%) as ligand.

Further investigation revealed that trifluoroethyl bromide (146) appeared to be a more effective reagent (Table 7 , entry 1 ). Further screening of reaction temperature and concentration showed that at $120{ }^{\circ} \mathrm{C}$ and at lower concentrations optimal results were achieved (Table 7, entries $4-7$ ). With no nickel catalyst or palladium dichloride as the catalyst no conversion was observed (Table 7, entries 12-13). Re-evaluating the previous conditions with BDMAE at $150{ }^{\circ} \mathrm{C}$ with trifluoroethyl bromide (143) showed improved conversion, as well (Table 7, entry 14).

Table 7: C-H trifluoroethylation with trifluoroethyl bromide (146). ${ }^{\text {[a] }}$
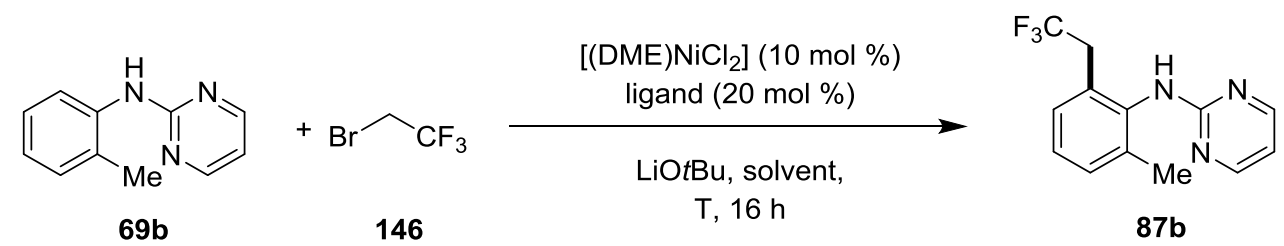

\begin{tabular}{|c|c|c|c|c|}
\hline entry & ligand & $\mathrm{T}\left[{ }^{\circ} \mathrm{C}\right]$ & solvent [M] & yield [\%] \\
\hline 1 & DtBEDA & 120 & 2-Me-THF (0.5) & 55 \\
\hline 2 & DtBEDA & 135 & 2-Me-THF (0.5) & 25 \\
\hline 3 & $\begin{array}{c}(R) \text {-BINOL (10 } \\
\text { mol\%) }\end{array}$ & 120 & 2-Me-THF (0.5) & 14 \\
\hline 4 & DtBEDA & 100 & 2-Me-THF (0.5) & 35 \\
\hline 5 & DtBEDA & 100 & 2-Me-THF (0.25) & 45 \\
\hline 6 & DtBEDA & 120 & 2-Me-THF (1.0) & 27 \\
\hline 7 & DtBEDA & 120 & 2-Me-THF (0.25) & $67\left(64^{[b]}\right)$ \\
\hline 8 & DtBEDA & 120 & 2-Me-THF (0.5) & $61^{[c]}$ \\
\hline 9 & DtBEDA & 120 & $\begin{array}{c}\text { 2-Me-THF/nOctane } \\
(1: 1)(0.5)\end{array}$ & 12 \\
\hline
\end{tabular}




\begin{tabular}{c|c|c|c|c}
\hline 10 & DtBEDA & 120 & 2-Me-THF (0.25) & $76\left(68^{[\mathrm{b}, \mathrm{c}]}\right)$ \\
11 & - & 120 & 2-Me-THF (0.5) & 38 \\
12 & DtBEDA & 120 & 2-Me-THF (0.5) & $0^{[\mathrm{d}]}$ \\
13 & DtBEDA & 120 & 2-Me-THF (0.5) & $0^{[\mathrm{e}]}$ \\
14 & BDMAE & 150 & PhMe (0.5) & $78^{[\mathrm{ff}]}\left(66^{[\mathrm{b}]}\right)$ \\
\hline
\end{tabular}

[a] Reactions conditions: 69b (1 mmol), $146(2 \mathrm{mmol})$, LiOtBu $(2 \mathrm{mmol})$, solvent, $150{ }^{\circ} \mathrm{C}, 16 \mathrm{~h}$, yields based on crude ${ }^{19} \mathrm{~F}$-NMR with $\mathrm{C}_{6} \mathrm{~F}_{6}$ as internal standard. ${ }^{[b]}$ isolated yield. ${ }^{[c]} 146$ (3 equiv). ${ }^{[d]}$ No catalyst. ${ }^{[\mathrm{e}]} \mathrm{PdCl}_{2}$ as catalyst. ${ }^{[\mathrm{ff}}$ ligand (40 $\left.\mathrm{mol} \%\right)$.

\subsubsection{Scope of Trifluoroethylation}

Initially, the catalytic system utilising DtBEDA as the ligand was probed, specifically for functional group tolerance (Scheme 61). However, both electron-rich and -deficient substrates gave only low to moderate yields. Chloro- and ester-substituents furnished no desired products 870 and $\mathbf{8 7 r}$.

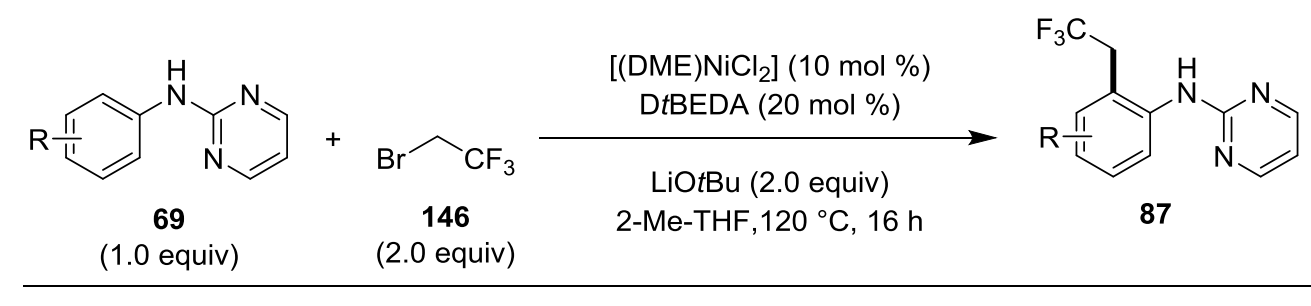<smiles>Fc1cccc(CC(F)(F)F)c1Nc1ncccn1</smiles>

87a: $54 \%$<smiles>Cc1cccc(CC(F)(F)F)c1Nc1ncccn1</smiles>

87b: $68 \%$<smiles>COc1cccc(CC(F)(F)F)c1Nc1ncccn1</smiles>

87c: $33 \%$<smiles>FC(F)(F)Cc1ccc(Cl)cc1Nc1ncccn1</smiles>

87m: $0 \%$<smiles>CCOC(=O)c1ccc(CC(F)(F)F)c(Nc2ncccc2CC(F)(F)F)c1</smiles>

87r: $0 \%$

Scheme 61: Scope for trifluoroethylation with DtBEDA as ligand.

Therefore, the study of substrates was continued with the BDMAE ligand system at $150{ }^{\circ} \mathrm{C}$ (Scheme 62). Both electron-deficient and -rich ortho-substituents were tolerated with moderate to high yields. meta-Substituted substrates 69I-n, however, gave low conversion with site-selectivity favoring the sterically less hindered position. Unsubstituted or electron- 
rich para-substituted substrates $69 \mathrm{~h} / \mathrm{k}-\mathrm{I}$ gave moderate yields. For these substrates the selectivity was mainly towards the mono-trifluoroethylated products $87 \mathrm{~h} / \mathbf{k}-\mathbf{l}$, with either none or only small amounts of bis-trifluoroethylated products $\mathbf{8 7} \mathbf{h}^{\prime}$ and $\mathbf{8 7} \mathbf{l}$ ' being isolated.
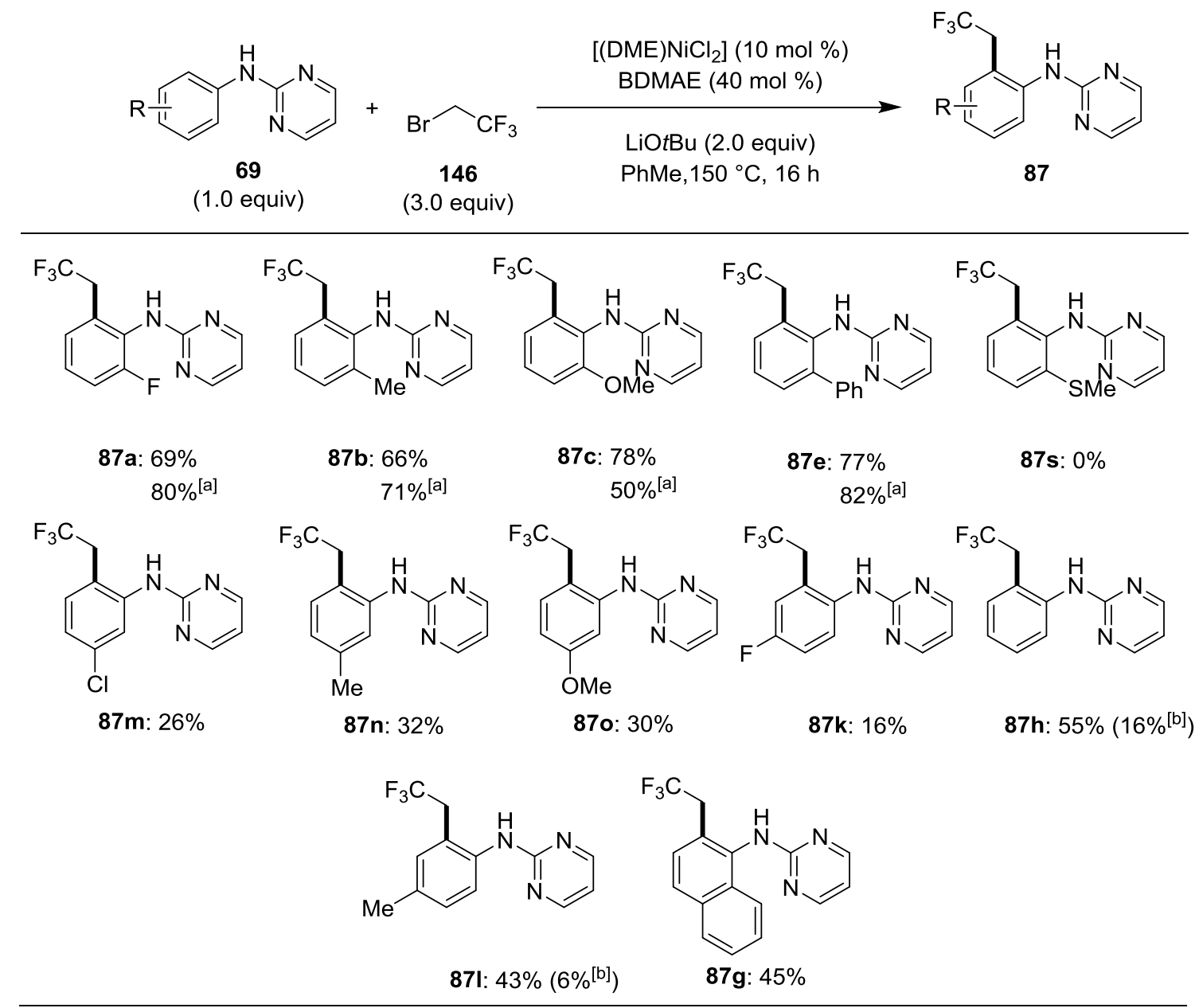

[a] $\mathrm{ICH}_{2} \mathrm{CF}_{3} 82$ (2 equiv) used. ${ }^{[b]}$ Bis-trifluoroethylated product.

Scheme 62: Scope for C-H trifluoroethylation with BDMAE as ligand.

Identically to the secondary alkylation of anilines, the reaction does not proceed if the acidic $\mathrm{N}-\mathrm{H}$ group is removed (Scheme 63).

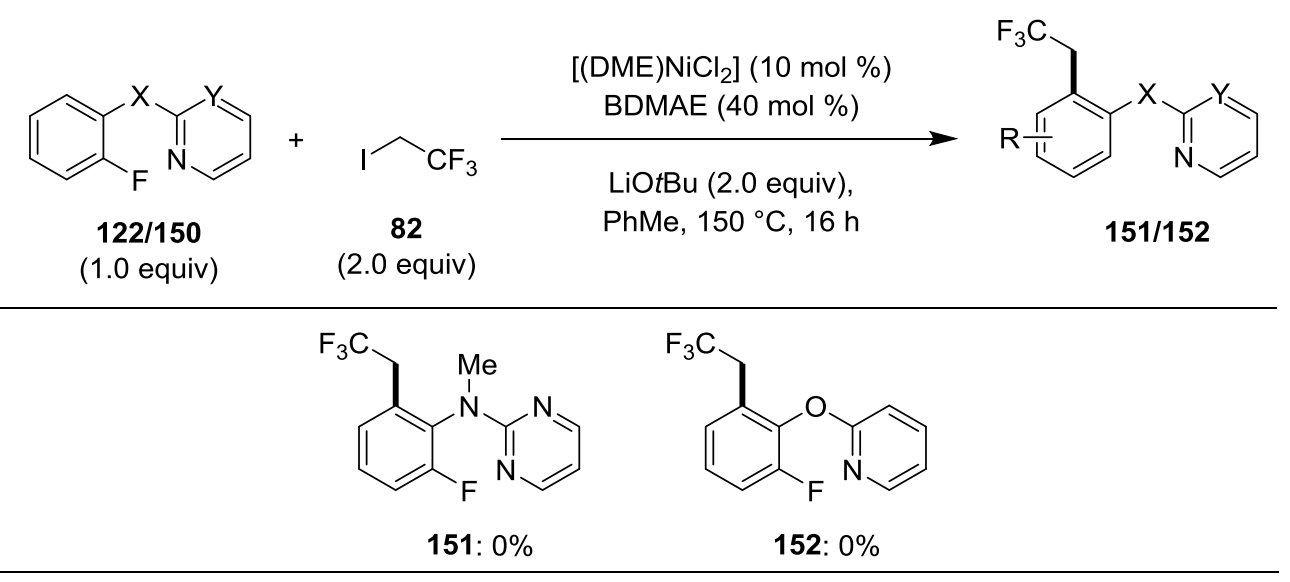

Scheme 63: Screening of directing groups for trifluoroethylation. 
While trifluoroethyl bromide $\mathbf{1 4 6}$ was identified as an effective reagent, it also contains possible drawbacks. One issue is the relatively high volatility of the reagent with a boiling point of $28^{\circ} \mathrm{C}$. Additionally, the reagent is currently not commercially available and only few syntheses have been reported. Therefore, the viability of the more easily accessible and nonvolatile tosylate derivative 145 was tested (Scheme 64). Albeit formation of only trace amounts with lithium bromide as additive, it could be shown that trifluoroethyl toslyate may be used for this type of transformation.

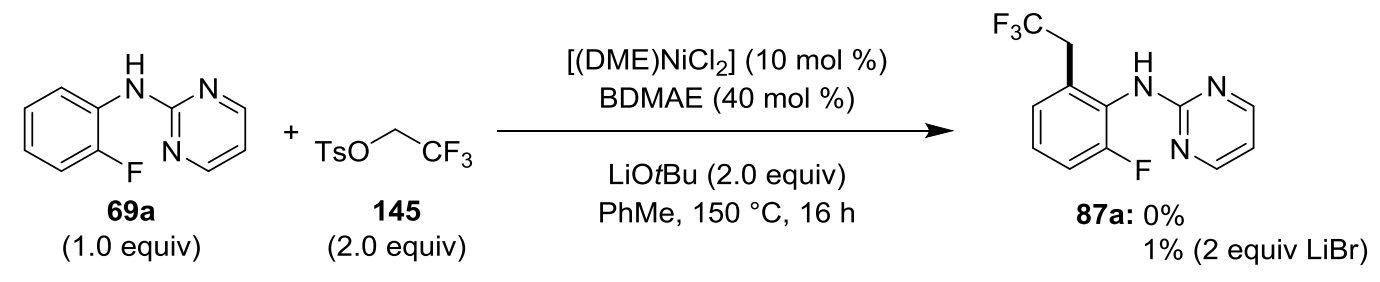

Scheme 64: Attempted C-H trifluoroethylation utilising trifluoroethyl tosylate (145).

\subsubsection{Mechanistic Studies}

Due to the novelty of this type of transformation several mechanistic experiments were conducted. In an H/D-exchange-experiment full scrambling was found, indicating a facile CH-metallation (Scheme 65).

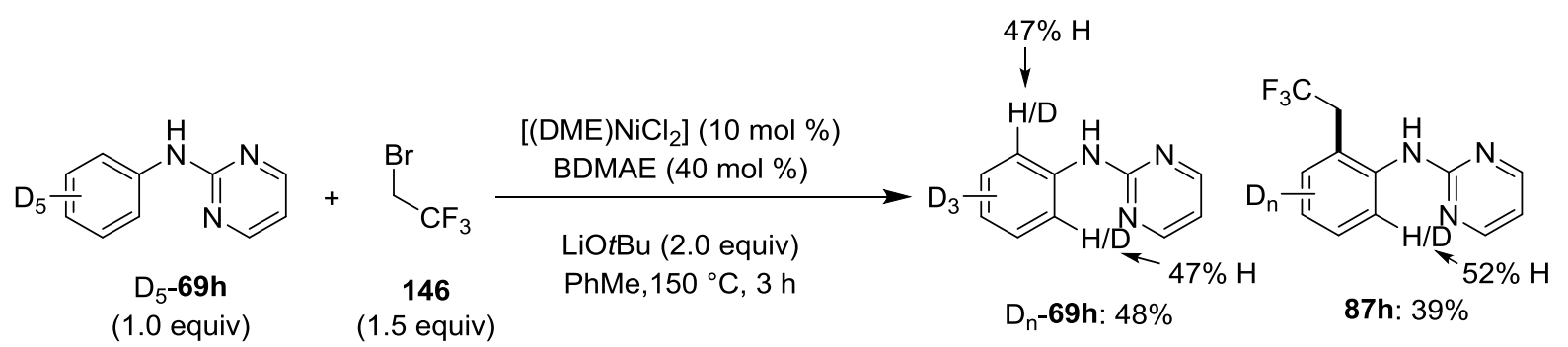

Scheme 65: H/D-exchange experiment for C-H trifluoroethylation.

Further, a direct competition between $69 \mathrm{~h}$ and $D_{5}-69 \mathrm{~h}$ revealed a KIE of $\mathrm{k}_{H} / \mathrm{k}_{\mathrm{D}}=1.1$ (Scheme $66)$, indicating the $\mathrm{C}-\mathrm{H}$-metallation not to being rate determining.

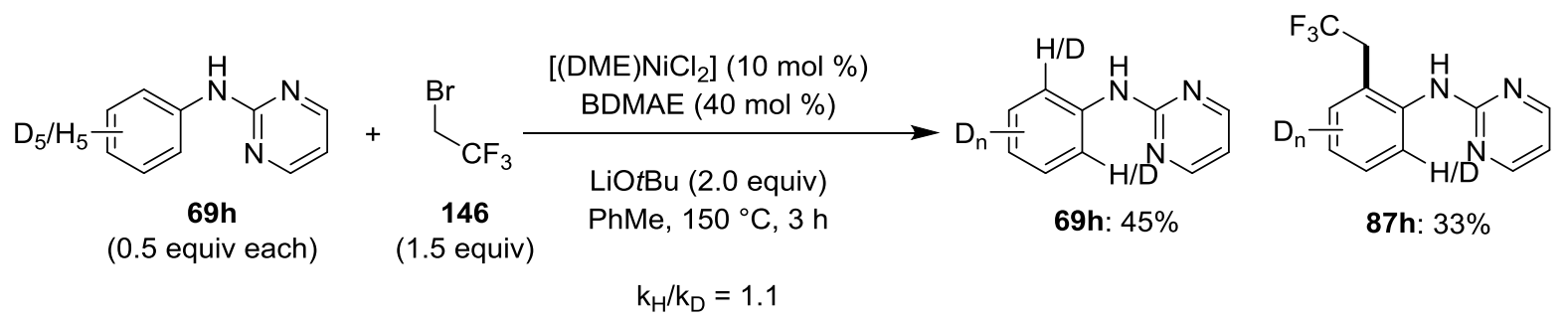

Scheme 66: Kinetic isotope effect. 
The reaction was shut down by the addition of one equivalent of the radical scavenger TEMPO (Scheme 67). The formation of radical intermediates can therefore be assumed.

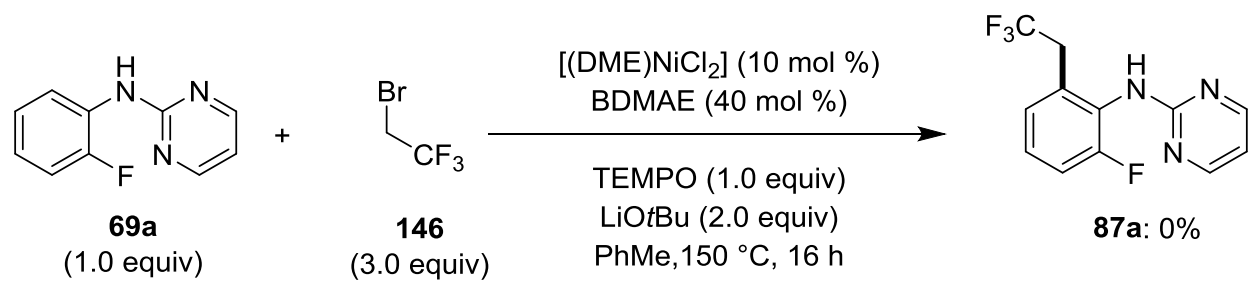

Scheme 67: Attempted trifluoroethylation with TEMPO.

A competition experiment between electron-rich and -deficient substrates revealed the electron-richer substrate to react preferentially (Scheme 68). This may point towards the oxidative addition being rate determining.

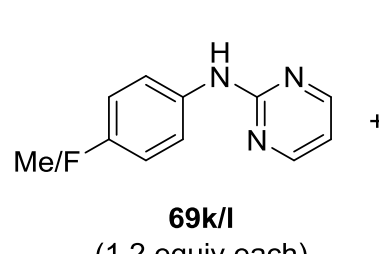

(1.2 equiv each)

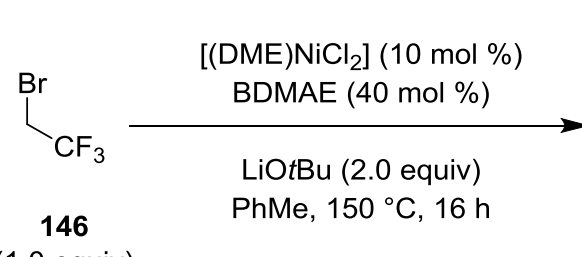

(1.0 equiv)

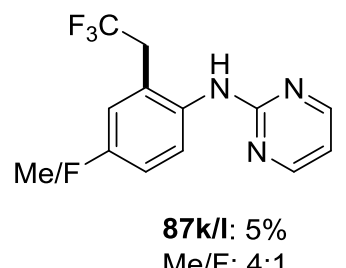

$\mathrm{Me} / \mathrm{F}: 4: 1$

Scheme 68: Competition experiment for trifluoroethylation under standard conditions.

Based on these findings a plausible catalytic cycle is proposed in Scheme 69. After the initial, facile $\mathrm{C}-\mathrm{H}$ nickelation, the oxidative addition occurs through a SET-type pathway. This is followed by the reductive elimination to give the desired product and regenerate the active catalyst. 


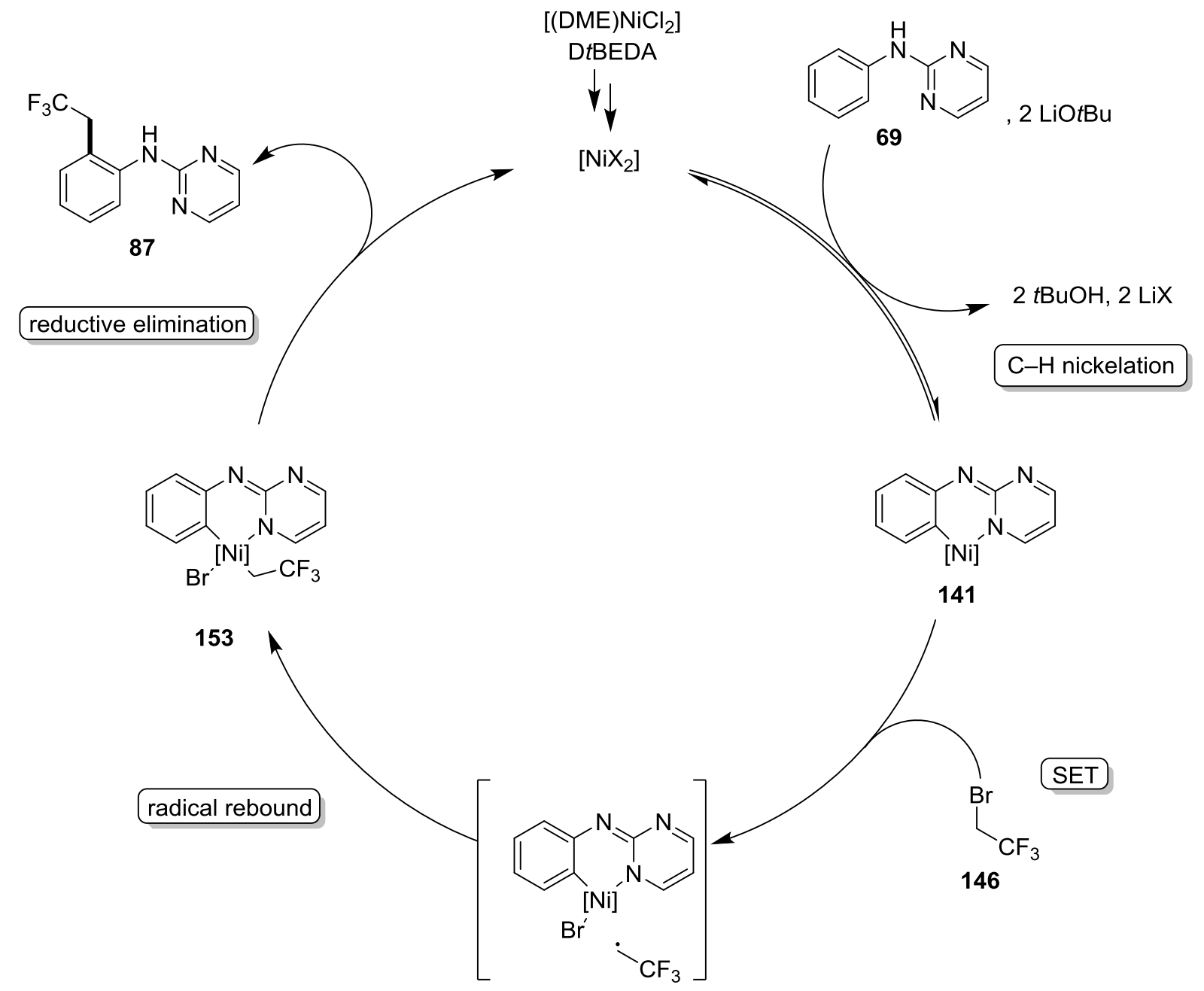

Scheme 69: Proposed catalytic cycle for the C-H trifluoroethylation.

\subsubsection{Further Fluoroalkylations}

Based on the novelty of the trifluoroethylation, further variations of fluoroalkylation reactions were probed. These were particularly focused on fluoroalkylation reagents containing alpha-fluoro-groups. Based on a previous report of nickel-catalysed cross coupling with iodofluoromethane (102), ${ }^{69}$ an analogous reaction was tested (Scheme 70). This, however, did not lead to the desired product 154.
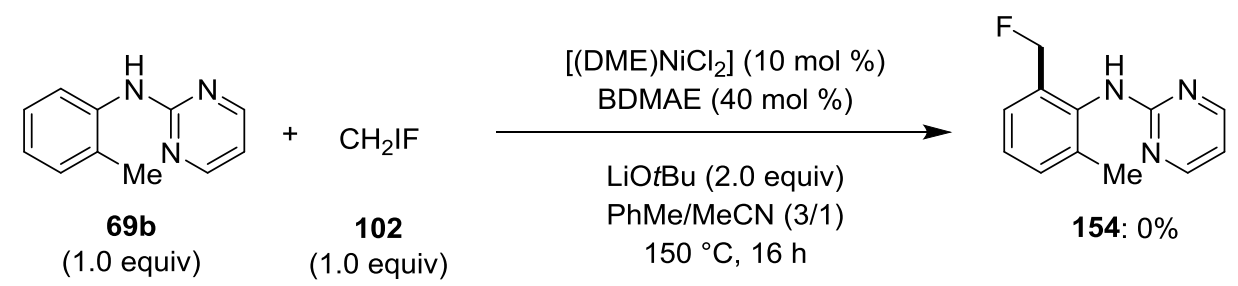

Scheme 70: Attempted C-H fluoromethylation of aniline 69b. 
Additionally, the Langlois' reagent (155) was tested for a direct trifluoromethylation (Scheme 71). This led only to a low conversion to side-product 153a.

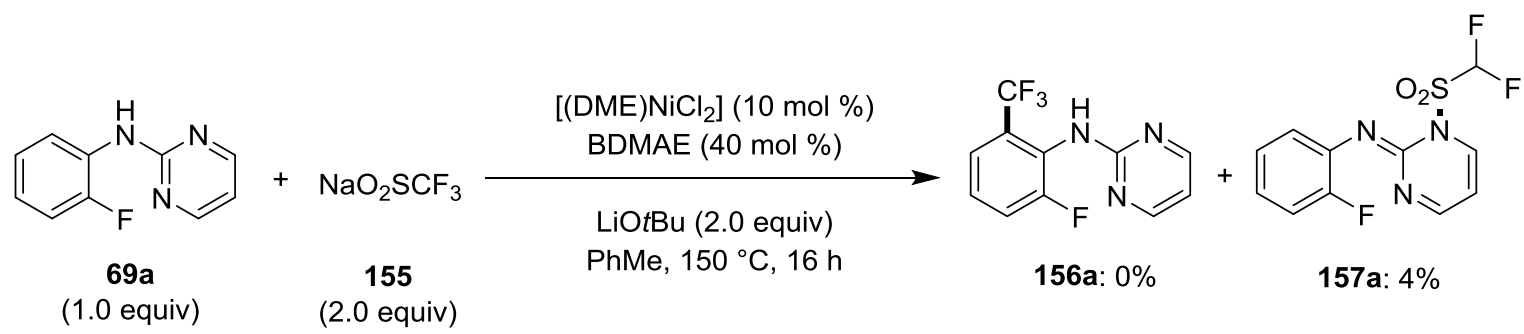

Scheme 71: Attempted trifluoromethylation of aniline 69a utilising Langlois' reagent. 


\section{Summary and Outlook}

The focus within this thesis was on the development of atom- and step-economic nickelcatalyzed alkylation reactions utilising challenging, unactivated alkyl halides with $\beta$ hydrogens or $\beta$-fluorines.

In the first part, a protocol for the direct $\mathrm{C}-\mathrm{H}$ secondary alkylation under bidentate assistance was devised for a variety of alkyl bromides 80 (Scheme 72). ${ }^{84}$ This was achieved using $\left[(\mathrm{DME}) \mathrm{NiCl}_{2}\right]$ as the catalyst with $\mathrm{BDMAE}$ as a commercially available ligand. A series of products $\mathbf{8 1}$ were obtained in good to excellent yields.

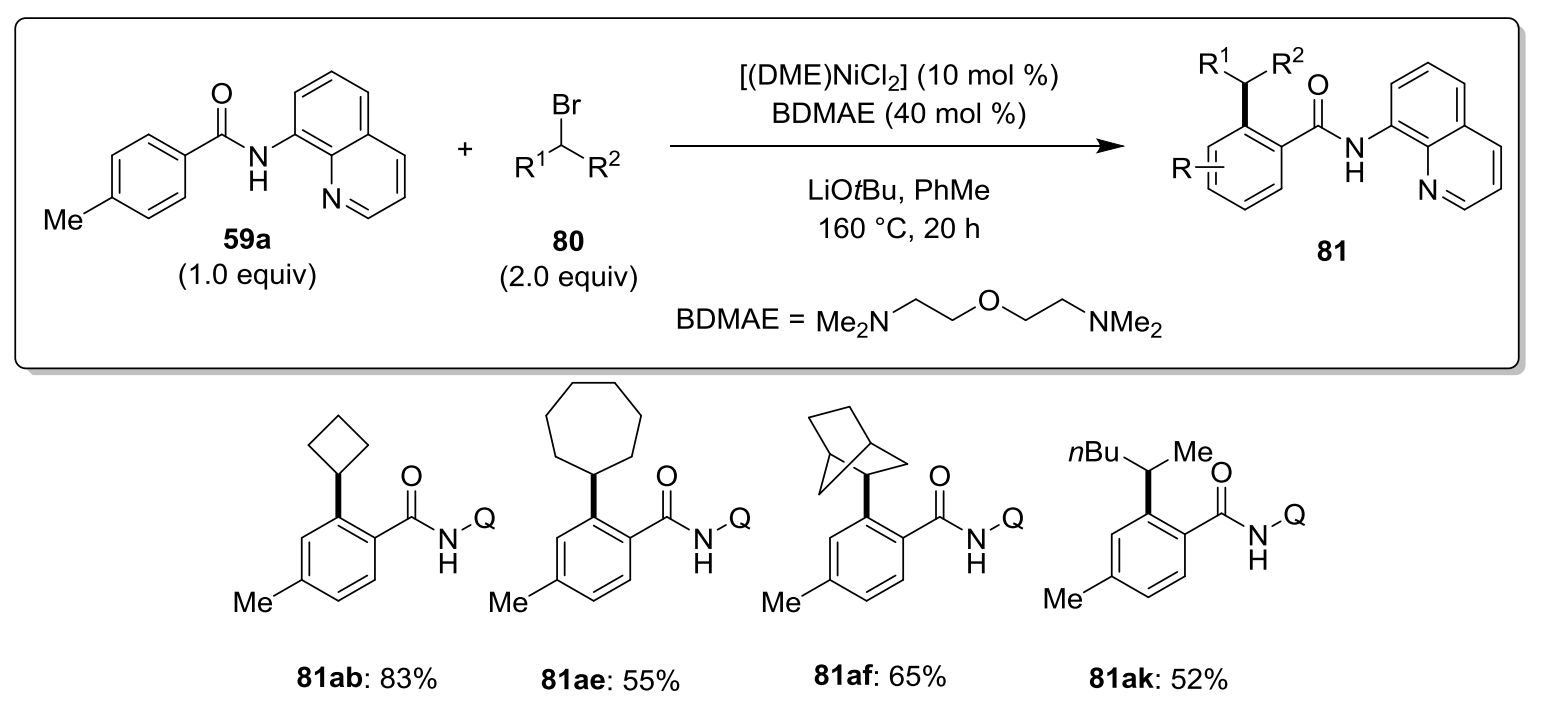

Scheme 72: C-H Secondary alkylation of benzamides under bidentate assistance.

Second, investigations on the first trifluoroethylation were conducted (Scheme 73). ${ }^{84}$ Albeit in low to moderate yields, the corresponding trifluoroethylated benzamides $\mathbf{8 4}$ were made accessible.

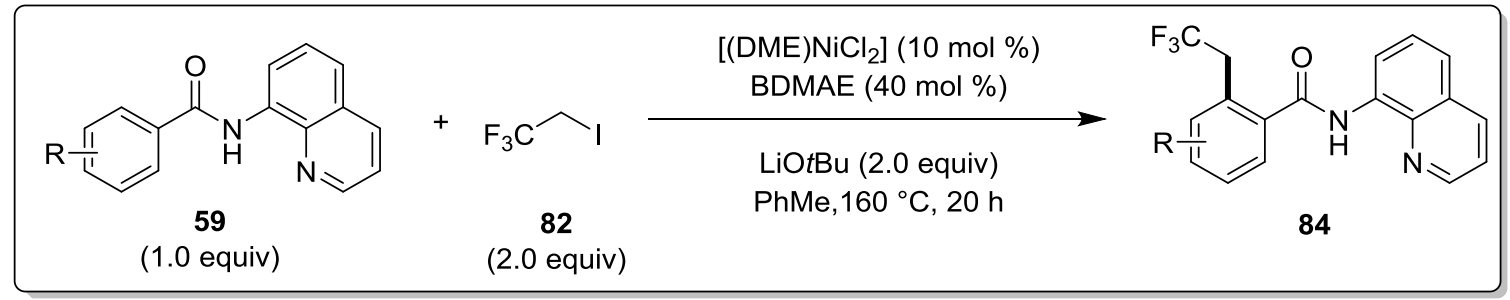

Scheme 73: C-H trifluoroethylation of benzamides 59 under bidentate assistance.

The research was then focused on utilising simpler and biologically relevant directing groups for direct $\mathrm{C}-\mathrm{H}$ secondary alkylation. For this a simple catalytic system consisting of

\footnotetext{
${ }^{84}$ Song, W.; Lackner, S.; Ackermann, L. Angew. Chemie Int. Ed. 2014, 53, 2477-2480.
} 
[(DME) $\mathrm{NiCl}_{2}$ ] and ligand DtBEDA was developed (Scheme 74$) .{ }^{85}$ The system showed broad applicability of substrates. Mechanistic studies revealed a reversible $\mathrm{C}-\mathrm{H}$ nickelation and a formal oxidative addition through an SET-type pathway. The involved nickelacycle is presumed to be an unusual 6-membered metallacycle 141.

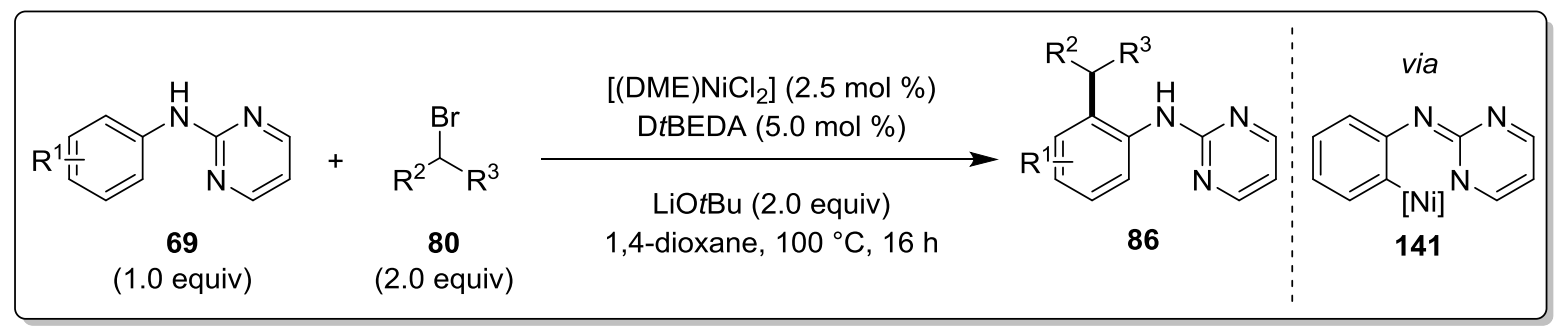<smiles>Fc1cccc(C2CCC2)c1Nc1ncccn1</smiles>

86ab: $87 \%$<smiles>CCCCCCCCCCCCCCCCCCCc1cccc(F)c1Nc1ncccn1</smiles>

86at: $92 \%$<smiles>Fc1cccc(C2CCCC2)c1Nc1ncccn1</smiles>

86af: $92 \%$

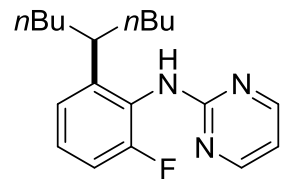

86at: $85 \%$

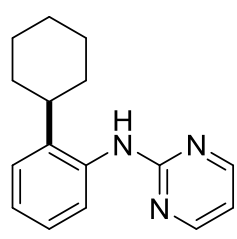

86ha: $54 \%$

Scheme 74: C-H Secondary alkylation of aniline derivatives 69.

Finally, the $\mathrm{C}-\mathrm{H}$ trifluoroethylation was applied to aniline derivatives 69 . The protocol was amenable to a variety of substrates 69 . Mechanistic studies revealed a reversible $\mathrm{C}-\mathrm{H}$ nickelation to be operative. The oxidative addition was proposed to occur via a SET-type pathway.

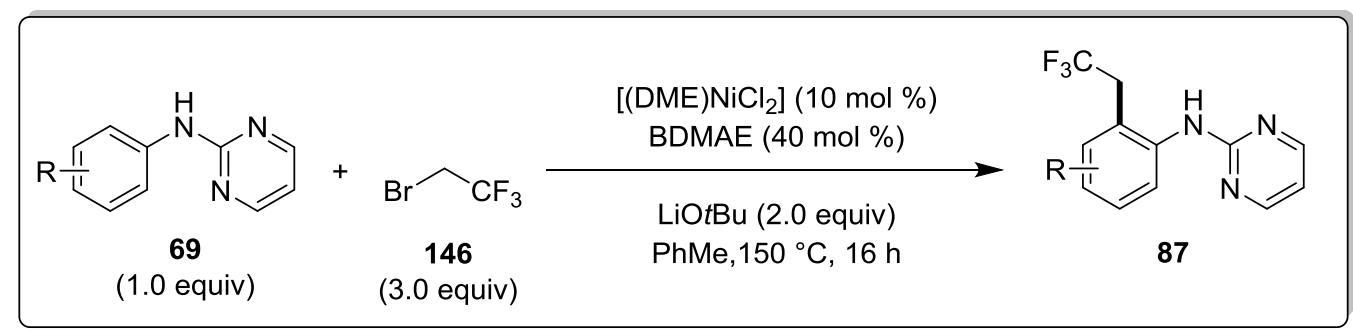<smiles>FCCc1cccc(F)c1Nc1ncccn1</smiles>

87a: $69 \%$<smiles>FC(F)(F)Cc1cccc(Nc2ncccn2)c1Nc1ccccc1</smiles>

87b: $66 \%$<smiles>COc1cccc(CC(F)(F)F)c1Nc1ncccn1</smiles>

87c: $78 \%$<smiles>FC(F)(F)Cc1cccc(-c2ccccc2)c1Nc1ncccn1</smiles>

87e: $77 \%$<smiles>FC(F)(F)Cc1ccccc1Nc1ncccn1</smiles>

87h: $55 \%$

Scheme 75: C-H Trifluoroethylation of aniline derivatives 69.

\footnotetext{
${ }^{85}$ Ruan, Z.; Lackner, S.; Ackermann, L. Angew. Chem. Int. Ed. 2016, 55, 3153-3157.
} 
Further research should focus on enabling tertiary alkylation and fluoroalkylations for the established substrates. The latter case being of particular interest, as novel palladiumcatalyzed $\mathrm{C}-\mathrm{H}$ trifluoroethylation reactions have been reported after publication of results presented herein. ${ }^{86} \mathrm{New}$ development of additional monodentate directing groups for nickel-catalysed $\mathrm{C}-\mathrm{H}$ functionalisation based on the 2-amino-pyrimidine moiety is also of importance. Moreover, if a catalytic system with higher efficacy at lower temperatures can be found, direct $\mathrm{C}-\mathrm{H}$ alkylation reactions in an enantioselective fashion may become feasible.

${ }^{86}$ (a) Toth, B. L.; Kovacs, S.; Salyi, G.; Novak, Z. Angew. Chem. Int. Ed. 2016, 55, 1988-1992. (b) Zhang, H.; Chen, P.; Liu, G. Angew. Chem. Int. Ed. 2014, 53, 10174-10178. 


\section{Experimental}

\subsection{General Remarks}

All reactions involving moisture- or air-sensitive reagents or products were performed under an argon atmosphere using pre-dried glassware and standard Schlenk techniques. Syringes for handling of dry solvents were flushed with dry argon threefold prior to their use.

\section{$\underline{\text { Solvents }}$}

All solvents for reactions involving moisture-sensitive reagents were dried, distilled and stored under inert atmosphere (argon or nitrogen) according to the following standard procedures.

$\underline{\text { solvent }}$

$\mathrm{CH}_{2} \mathrm{Cl}_{2}$

N,N-Dimethylformamide

N-Methyl-2-pyrrolidone

Methanol

Tetrahydrofuran

Toluene

\section{1,4-Dioxane}

nOctane

Diphenylether

Chlorobenzene

\section{drying method}

was purified using an solvent purification system (SPS) from MBRAUN.

was dried over $\mathrm{CaH}_{2}$ for $8 \mathrm{~h}$, degassed and distilled under reduced pressure.

was stirred for $4 \mathrm{~h}$ at $150{ }^{\circ} \mathrm{C}$ over $\mathrm{CaH}_{2}$ and subsequently distilled under reduced pressure.

was stirred over $\mathrm{Mg}$ chips for $3 \mathrm{~h}$ at $65^{\circ} \mathrm{C}$ prior to distillation.

was purified using an SPS solvent purification system from MBRAUN.

was either predried over $\mathrm{KH}$ followed by distillation from sodium benzophenone ketyl or purified using a solvent purification system from MBRAUN.

was dried by distillation from sodium benzophenone ketyl.

was dried by addition of predried $4 \AA$ molecular sieve.

was dried by addition of predried $4 \AA$ molecular sieve.

was dried by addition of predried $4 \AA$ molecular sieve. 
5 Experimental

tert-Butylbenzene

Trifluoromethylbenzene

Anisole

Dimethoxyethane

Di-(n-butyl)-ether

CPME

tert-Butanol

2-Methyl-tetrahydrofuran was dried by addition of predried $4 \AA ̊$ molecular sieve.

was dried by addition of predried $4 \AA ̊$ molecular sieve.

was dried by stirring over $\mathrm{Na}$ at $135{ }^{\circ} \mathrm{C}$ prior to disitillation at 1 mbar.

was dried by distillation from sodium benzophenone ketyl.

was dried by distillation from sodium benzophenone ketyl.

was dried by stirring over sodium at $120^{\circ} \mathrm{C}$ prior to disitillation.

was dried by distillation from sodium.

was dried by distillation from sodium.

\section{Vacuum}

The following pressures were measured on the used vacuum pump and were not corrected: membrane pump vacuum (MPV): 0.5 mbar, oil pump vacuum (OPV): 0.1 mbar.

\section{Melting Points}

Melting points were measured using a Stuart ${ }^{\circledR}$ Melting Point Apparatus SMP3 from BARLOWORLD SCIENTIFIC. Reported values are not corrected.

\section{Chromatography}

Analytical thin layer chromatography (TLC) was performed on $0.25 \mathrm{~mm}$ silica gel 60F-plate (MACHEREY-NAGEL) with $254 \mathrm{~nm}$ fluorescent indicator from MERCK. Plates were either visualized under ultraviolet light or developed by treatment with a potassium permanganate or a cerium ammonium molybdate solution followed by careful warming with a heat gun. Chromatographic purification of products was accomplished by flash column chromatography on MERCK silica gel, grade $60(40-63 \mu \mathrm{m}$ and 63-200 $\mu \mathrm{m}, 70-230$ mesh ASTM).

\section{High Performance Liquid Chromatography}

Preparative and analytical separations were performed on an HPLC-System from Agilent. Separation column ChiralPak IC $(4.6 \times 250 \mathrm{~mm})$ from DAICEL CHEM. IND. (LTD) was used. 
Organic solvents of HPLC grade were employed. All samples were filtered through Polytetrafluorethylen Filter from ROTH ( $\varnothing 25 \mathrm{~mm}, 0.2 \mu \mathrm{m}$ ) or VWR ( $\varnothing 13 \mathrm{~mm}, 0.2 \mu \mathrm{m})$ prior to separation.

\section{Gas Chromatography}

Monitoring of reaction processes via coupled gas chromatography-mass spectrometry was performed using G1800C GCDplus with mass detector HP 5971, 5890 Series II with mass detector HP 5972 from HEWLETT-PACKARD and 7890A GC-System with mass detector 5975C (Triplex-Axis-Detector) from AGILENT TECHNOLOGIES. HP-5MS columns (30 m $\times 0.25 \mathrm{~mm}$, film $0.25 \mu \mathrm{m}$ ) were used.

\section{Gel permeation chromatography}

Preparative and analytical separations were performed on an GPC-System from Japan Analytical Industry, Co. Separation column JAIGEL-1HH was used. HPLC grade chloroform stabilized with $0.6 \%$ ethanol was employed. All samples were filtered through Polytetrafluorethylen Filter from ROTH ( $\varnothing 25 \mathrm{~mm}, 0.2 \mu \mathrm{m})$ or VWR ( $\varnothing 13 \mathrm{~mm}, 0.2 \mu \mathrm{m})$ prior to separation.

\section{Infrared Spectroscopy}

Infrared spectra were recorded using a BRUKER Alpha-P ATR spectrometer. Liquid samples were measured as film and solid samples neat. Analysis of the spectral data was carried out using OPUS 6. Absorption is given in wave numbers $\left(\mathrm{cm}^{-1}\right)$. Spectra were recorded in the range from 4000 to $400 \mathrm{~cm}^{-1}$.

\section{Mass Spectrometry}

EI- and El-HR-MS spectra were measured on a Time-of-Flight mass spectrometer AccuTOF from JOEL. ESI-mass spectra were recorded on an Ion-Trap mass spectrometer LCQ from FINNIGAN or on a Time-of-Flight mass spectrometer microTOF from BRUKER. ESI-HR-MS spectra were recorded on a BRUKER APEX IV (7T, Transform Ion Cyclotron Resonance (FTICR)) mass spectrometer. The ratios of mass to charge are indicated, intensities relative to the base peak $(I=100)$ are written in parentheses. 


\section{Nuclear Magnetic Resonance Spectroscopy (NMR)}

Nuclear magnetic resonance (NMR) spectra were recorded at 300 or $600 \mathrm{MHz}$ (1H NMR), 75 or $125 \mathrm{MHz}$ (13C NMR and APT) and $282 \mathrm{MHz}$ (19F NMR) on VARIAN Unity-300, AMX 300, Inova-500 and Inova-600 instruments. Chemical shifts are reported as $\delta$-values in ppm relative to the residual proton peak or the carbon peak of the deuterated solvent.

$$
{ }^{1} \mathrm{H} N M R \quad{ }^{13} \mathrm{CNMR}
$$

$\mathrm{CDCl}_{3} \quad 7.26 \mathrm{ppm} \quad 77.2 \mathrm{ppm}$

DMSO- $_{6} \quad 2.54 \mathrm{ppm} \quad 40.5 \mathrm{ppm}$

benzene- $d_{6} \quad 7.16 \mathrm{ppm} \quad 128.1 \mathrm{ppm}$

For characterization of the observed resonance multiplicities the following abbrevations were applied: s (singlet), d (doublet), t (triplet), q (quartet), pent (pentet), hept (heptet), $m$ (multiplet) or analogous representations. The coupling constants J are reported in $\mathrm{Hertz}(\mathrm{Hz})$. Analysis of the recorded spectra were carried out using MestReNova 10.0 software.

\section{Optical Rotatory Power}

Optical rotations were measured with digital polarimeters PERKIN-ELMER 241 or JASCO P2000 in a $1 \mathrm{dm}$ cell. The optical rotary powers $\alpha$ in the indicated solvents are given in ${ }^{\circ}$ at the indicated temperatures.

\section{Reagents}

Chemicals obtained from commercial sources with purity above $95 \%$ were used without further purification.

The following compounds were synthesised according to known literature procedures and were pure by comparison with the published analytical data:

(3-bromobutyl)benzene (80n), ${ }^{87}$ 2-(4-Bromopentyl)isoindoline-1,3-dione $\quad(80 \mathrm{p}),{ }^{88}$ (6S)-8Bromo-2,6-dimethylnon-2-ene (80r), ${ }^{87} 4$-Methyl- $N$-(pyridin-2-ylmethyl)benzamide (80a), ${ }^{89} 4$ methyl- $N$-(thiophen-2-ylmethyl)benzamide (95a), ${ }^{89}(\mathrm{~L})$-Valinol (97), ${ }^{90}$ (S)-4-Methyl-2-(pyridin2-yl)-4,5-dihydrooxazole (98), ${ }^{91} \mathrm{~N}$-(Quinolin-8-yl)pivalamide (62a), ${ }^{92} \mathrm{~N}$-(2-pyrimidyl)-anilines

\footnotetext{
${ }^{87}$ Gonzalez-Bobes, F.; Fu, G. C. J. Am. Chem. Soc. 2006, 128, 5360-5361.

${ }^{88}$ Bothmann, H.; Roncarati, R.; Bettinetti, L.; Quinn, J.; Varrone, M.; Valacchi, M.; Nencini, A.; Micco, I.; Ghiron, C.; Haydar, S. PCT Int. Appl. 2007, WO 2007098826 A2 Sep 07, 2007.

${ }^{89}$ Inoue, S.; Shiota, H.; Fukumoto, Y.; Chatani, N. J. Am. Chem. Soc. 2009, 131, 6898-6899.

${ }^{90}$ Hsiao, Y.; Hegedus, L. S. J. Org. Chem 1997, 62, 3586-3591.

${ }^{91}$ Binder, J. T.; Cordier, C. J.; Fu, G. C. J. Am. Chem. Soc. 2012, 134, 17003-17006.
} 
$(69 \mathrm{~h} / \mathrm{i} / \mathbf{j} / \mathbf{q}),{ }^{93}$ cyclododecylbromide (80t), ${ }^{94}$ methyl 5-bromohexanoate (80u), ${ }^{95}$ (S)-2bromooctane $((S)-80 k),{ }^{96} \mathrm{~N}$-(2-fluorophenyl)pyridin-2-amine (123), ${ }^{97}$ 2,4-dichloropyrimidine (157), ${ }^{98} \mathrm{~N}$-Phenylmorpholine-4-carbothioamide (125), ${ }^{99} \mathrm{~N}$-methyl- $\mathrm{N}$-phenylpyrimidin-2amine (122), ${ }^{100}$ cyclohexylacetate (137), ${ }^{101} \mathrm{~N}$-(phenyl- $\left.\mathrm{d}_{5}\right)$ pyrimidin-2-amine $\left(\mathrm{D}_{5}-69 \mathrm{~h}\right),{ }^{102}$ 2,2,2-trifluoroethyl 4-methylbenzenesulfonate (145). ${ }^{103}$

The following compounds were obtained by the generous courtesy of the following persons:

Dr. Weifeng Song: $N$-(quinolin-8-yl)benzamides (59a-g),

Dr. Jie Li: N-Methylbenzamide (92a), 1,3-Bis((S)-1-phenylethyl)-1H-imidazol-3-ium chloride (99)

Dr. Xu Tian: (S)-4-Isopropyl-2-(pyridin-2-yl)-4,5-dihydrooxazole (117)

M. Sc. Zhixiong Ruan: N-(2-Pyrimidyl)-anilines (69I-p/r)

M. Sc. Marc Moselage: 3-Methyl-1-(pyrimidin-2-yl)-1H-indole (127), 1,3-Dimethyl-3,4,5,6tetrahydro-2(1H)-pyrimidinone (dry)

M. Sc. Alexandra Schischko: Methyl N'-acetyl-1-(pyrimidin-2-yl)tryptophanate (128)

M. Sc. Thomas Müller: N-(2-Pyrimidyl)-anilines (69s)

\subsection{General Procedures}

\section{General Procedure A}

To solution of aniline 107 (2.0 equiv) in dry THF (1.5 mL/mmol) was added $n$-butyllithium (2.0 equiv) under stirring at $-78{ }^{\circ} \mathrm{C}$. The reaction was stirred for $15 \mathrm{~min}$ at ambient temperature, cooled to $-78{ }^{\circ} \mathrm{C}$ and 2-chloropyrimidin (106) was slowly added as a suspension

\footnotetext{
${ }^{92}$ Zhu, L.; Qiu, R.; Cao, X.; Xiao, S.; Xu, X.; Au, C.-T.; Yin, S.-F. Org. Lett. 2015, 17, 5528-5531.

${ }^{93}$ Ackermann, L.; Lygin, A. V. Org. Lett. 2012, 14, 764-767.

${ }^{94}$ Masson, E.; Leroux, F. Helvetica Chimica Acta 2005, 88, 1375-1386.

${ }^{95}$ Schmidt, V. A.; Quinn, R. K.; Brusoe, A. T.; Alexanian, E. J. J. Am. Chem. Soc. 2014, 136, 14389-14392.

${ }^{96}$ Liang, Y.; Fu, G. C. J. Am. Chem. Soc. 2015, 137, 9523-9526.

${ }^{97}$ Qian, G.; Liu, B.; Tan, Q.; Zhang, S.; Xu, B. Eur. J. Org. Chem. 2014, 22, 4837-4843.

${ }^{98}$ Whittaker, N.; Jones, T. S. G. J. Chem. Soc. 1951, 1565-1570.

${ }^{99}$ Biswas, K.; Greaney, M. F. Org. Lett. 2011, 13, 4946-4949.

100 Johansson Seechurn, C. C. C.; Parisel, S. L.; Colacot, T. J. J. Org. Chem. 2011, 76, 7918-7932.

${ }^{101}$ Ranu, B. C., Dey, S. S.; Hajra, A. Green Chemistry 2003, 5, 44-46.

102 Liu, Y.; Bai, Y.; Zhang, J.; Li, Y.; Jiao, J.; Qi, X. Eur. J. Org. Chem. 2007, 6084-6088.

${ }^{103}$ Li, L.; Huang, M.; Liu, C.; Xiao, J.-C.; Chen, Q.-Y.; Guo, Y.; Zhao, Z.-G. Org. Lett. 2015, 17, 4714-4717.
} 
in THF $(0.5 \mathrm{~mL})$. The reaction mixture was slowly warmed to ambient temperature and stirred for $16 \mathrm{~h}$. The reaction was stopped by addition of saturated, aqueous $\mathrm{Na}_{2} \mathrm{CO}_{3}$ solution. After extraction with EtOAc, the organic phase was dried over $\mathrm{Na}_{2} \mathrm{SO}_{4}$ and concentrated in vacuo. The crude product was purified by flash column chromatography, followed by recrystallization from hot toluene to yield 69.

\section{General Procedure B:}

To a mixture of benzamide $59(0.50 \mathrm{mmol})$, alkylbromide 80 (1.00 mmol), [(DME) $\mathrm{NiCl}_{2}$ ] (11 mg, $10.0 \mathrm{~mol} \%$ ), BDMAE (32 mg, $40 \mathrm{~mol} \%$ ) and LiOtBu ( $80 \mathrm{mg}, 1.00 \mathrm{mmol}$ ) was added PhMe $(1.0 \mathrm{~mL})$. Thereafter, the reaction mixture was stirred under $\mathrm{Ar}$ at $160{ }^{\circ} \mathrm{C}$ for $20 \mathrm{~h}$. After cooling to ambient temperature, the crude product was purified by column chromatography on silica gel to yield product $\mathbf{8 1}$.

\section{General Procedure C:}

To a mixture of benzamide $59(0.50 \mathrm{mmol})$, trifluoroethyl iodide $(82)$ (1.00 $\mathrm{mmol})$, [(DME) $\mathrm{NiCl}_{2}$ ] (11 mg, $10.0 \mathrm{~mol} \%$ ), BDMAE (32 mg, $40 \mathrm{~mol} \%$ ) and LiOtBu (80 mg, $1.00 \mathrm{mmol}$ ) was added dry PhMe $(1.0 \mathrm{~mL})$. Thereafter, the reaction mixture was stirred under Ar at $160{ }^{\circ} \mathrm{C}$ for $20 \mathrm{~h}$.After cooling to ambient temperature, the crude product was purified by column chromatography on silica gel to yield product $\mathbf{8 4}$.

\section{$\underline{\text { General Procedure D1 }}$}

Anilines 69 (1.0 mmol), [(DME) $\left.\mathrm{NiCl}_{2}\right](5.5 \mathrm{mg}, 2.5 \mathrm{~mol} \%)$ and LiOtBu (160 mg, $\left.2.0 \mathrm{mmol}\right)$ were placed in a $25 \mathrm{~mL}$ Schlenk tube. The tube was evacuated and purged with Ar three times. DtBEDA (11.0 $\mu \mathrm{L}, 5.0 \mathrm{~mol} \%)$, alkyl bromides 80 (2.0 mmol) and 1,4-dioxane $(2.0 \mathrm{~mL})$ were then added, and the mixture was stirred at $100{ }^{\circ} \mathrm{C}$ for $16 \mathrm{~h}$. At ambient temperature, $\mathrm{CH}_{2} \mathrm{Cl}_{2}(2.0 \mathrm{~mL})$ was added, concentrated under reduced pressure and purified by flash column chromatography on silica gel to afford the product $\mathbf{8 6}$.

\section{$\underline{\text { General Procedure D2 }}$}

Anilines 69 (1.0 mmol), [(DME) NiCl 2 (11 mg, $5.0 \mathrm{~mol} \%$ ) and LiOtBu (160 mg, $2.0 \mathrm{mmol})$ were placed in a $25 \mathrm{~mL}$ Schlenk tube. The tube was evacuated and purged with Ar three times. DtBEDA (22.0 $\mu \mathrm{L}, 10 \mathrm{~mol} \%)$, alkyl bromides $80(2.0 \mathrm{mmol})$ and 1,4-dioxane $(2.0 \mathrm{~mL})$ were then added, and the mixture was stirred at $120^{\circ} \mathrm{C}$ for $16 \mathrm{~h}$. At ambient temperature, $\mathrm{CH}_{2} \mathrm{Cl}_{2}$ $(2.0 \mathrm{~mL})$ was added, concentrated under reduced pressure and purified by flash column chromatography on silica gel to afford the products $\mathbf{8 6}$. 


\section{$\underline{\text { General Procedure D3 }}$}

Anilines 69 (1.0 mmol), [ $\left.\mathrm{NiCl}_{2}\left(\mathrm{H}_{2} \mathrm{O}\right)_{6}\right]$ ( $6 \mathrm{mg}, 2.5 \mathrm{~mol} \%$ ) and LiOtBu (160 mg, $2.0 \mathrm{mmol}$ ) were placed in a $25 \mathrm{~mL}$ Schlenk tube. The tube was evacuated and purged with Ar three times. DtBEDA (11.0 $\mu \mathrm{L}, 10 \mathrm{~mol} \%)$, alkyl bromides $80(2.0 \mathrm{mmol})$ and 1,4-dioxane $(2.0 \mathrm{~mL})$ were then added, and the mixture was stirred at $120^{\circ} \mathrm{C}$ for $16 \mathrm{~h}$. At ambient temperature, $\mathrm{CH}_{2} \mathrm{Cl}_{2}$ $(2.0 \mathrm{~mL})$ was added, concentrated under reduced pressure and purified by flash column chromatography on silica gel to afford the products $\mathbf{8 6}$.

\section{General Procedure E1}

Anilines 69 (1.0 mmol), [(DME) NiCl ${ }_{2}$ ( $22 \mathrm{mg}, 10 \mathrm{~mol} \%$ ) and LiOtBu (160 mg, $2.0 \mathrm{mmol}$ ) were placed in a $25 \mathrm{~mL}$ sealed tube. The tube was evacuated and purged with Ar three times. DtBEDA $(42.0 \mu \mathrm{L}, 20 \mathrm{~mol} \%)$ and 2-Me-THF $(2.0 \mathrm{~mL})$ were then added. The reaction was cooled to $-78{ }^{\circ} \mathrm{C}$, trifluoroethylbromide (146) $(489 \mathrm{mg}, 3.0 \mathrm{mmol}$ ) was added and the mixture was stirred at $120{ }^{\circ} \mathrm{C}$ for $16 \mathrm{~h}$. At ambient temperature, $\mathrm{CH}_{2} \mathrm{Cl}_{2}(2.0 \mathrm{~mL})$ was added, the mixture was concentrated under reduced pressure and purified by flash column chromatography on silica gel to afford the products 87 .

\section{$\underline{\text { General Procedure E2 }}$}

Anilines 69 (1.0 mmol), [(DME) NiCl ${ }_{2}$ ( $22 \mathrm{mg}, 10 \mathrm{~mol} \%$ ) and LiOtBu (160 mg, $2.0 \mathrm{mmol}$ ) were placed in a $25 \mathrm{~mL}$ sealed tube. The tube was evacuated and purged with Ar three times. BDMAE $(76.0 \mu \mathrm{L}, 40 \mathrm{~mol} \%)$ and $\mathrm{PhMe}(2.0 \mathrm{~mL})$ were then added. The reaction was cooled to $-78{ }^{\circ} \mathrm{C}$, trifluoroethylbromide (146) $(489 \mathrm{mg}, 3.0 \mathrm{mmol}$ ) was added and the mixture was stirred at $150{ }^{\circ} \mathrm{C}$ for $16 \mathrm{~h}$. At ambient temperature, $\mathrm{CH}_{2} \mathrm{Cl}_{2}(2.0 \mathrm{~mL})$ was added, the mixture was concentrated under reduced pressure and purified by flash column chromatography on silica gel to afford the products 87 .

\section{$\underline{\text { General Procedure E3 }}$}

Anilines 69 (1.0 mmol), [(DME) NiCl 2 ] (22 mg, $10 \mathrm{~mol} \%$ ) and LiOtBu (160 mg, $2.0 \mathrm{mmol}$ ) were placed in a $25 \mathrm{~mL}$ sealed tube. The tube was evacuated and purged with Ar three times. $\operatorname{BDMAE}(76.0 \mu \mathrm{L}, 40 \mathrm{~mol} \%)$, trifluoroethyliodide (82) $(420 \mathrm{mg}, 2.0 \mathrm{mmol})$ and PhMe $(2.0 \mathrm{~mL})$ were then added, and the mixture was stirred at $100{ }^{\circ} \mathrm{C}$ for $16 \mathrm{~h}$. At ambient temperature, $\mathrm{CH}_{2} \mathrm{Cl}_{2}(2.0 \mathrm{~mL})$ was added, the mixture was concentrated under reduced pressure and purified by flash column chromatography on silica gel to afford the products 87 . 


\subsection{Experimental and Analytical Data}

\subsubsection{Analytical Data for Substrates}

Synthesis of $\mathrm{N}$-(2-fluorophenyl)pyrimidin-2-amine (69a)<smiles>Fc1ccccc1Nc1ncccn1</smiles>

The general procedure A was followed using $107 \mathrm{a}(6.83 \mathrm{~g}, 61.5 \mathrm{mmol})$ and $106(3.44 \mathrm{~g}$, $30.0 \mathrm{mmol}$ ). After purification by column chromatography ( $n$-hexane/EtOAc 95:5) and recrystallisation $69 \mathrm{a}(3.47 \mathrm{~g}, 61 \%)$ was obtained as a white solid. Analytical data was identical to that previously reported. ${ }^{104}$

M.p.: $114-115^{\circ} \mathrm{C}$

${ }^{1} \mathrm{H}$ NMR $\left(300 \mathrm{MHz}, \mathrm{CDCl}_{3}\right): \delta=8.45(\mathrm{~d}, J=4.8 \mathrm{~Hz}, 2 \mathrm{H}), 8.43(\mathrm{ddd}, J=8.5,8.3,1.7 \mathrm{~Hz}, 1 \mathrm{H}), 7.59$ $(\mathrm{s}, 1 \mathrm{H}), 7.19-7.06(\mathrm{~m}, 2 \mathrm{H}), 6.98(\mathrm{dddd}, J=8.3,7.3,5.1,1.7 \mathrm{~Hz}, 1 \mathrm{H}), 6.76(\mathrm{t}, J=4.8 \mathrm{~Hz}, 1 \mathrm{H})$.

${ }^{13} \mathrm{C}$ NMR $\left(125 \mathrm{MHz}, \mathrm{CDCl}_{3}\right): \delta=159.9\left(\mathrm{C}_{\mathrm{q}}\right), 158.0(\mathrm{CH}), 152.8\left(\mathrm{C}_{\mathrm{q}}, \mathrm{d},{ }^{1}{ }_{\mathrm{C}-\mathrm{F}}=240.3 \mathrm{~Hz}\right), 128.0\left(\mathrm{C}_{\mathrm{q}}\right.$, d, $\left.{ }^{2} J_{C-F}=9.9 \mathrm{~Hz}\right), 124.3\left(\mathrm{CH}, \mathrm{d},{ }^{4} J_{\mathrm{C}-\mathrm{F}}=3.3 \mathrm{~Hz}\right), 122.6\left(\mathrm{CH}, \mathrm{d},{ }^{3} J_{\mathrm{C}-\mathrm{F}}=7.8 \mathrm{~Hz}\right), 121.0(\mathrm{CH}), 114.9$ $\left(\mathrm{CH}, \mathrm{d},{ }^{2} J_{\mathrm{C}-\mathrm{F}}=19.3 \mathrm{~Hz}\right), 113.1(\mathrm{CH})$.

${ }^{19}$ F NMR $\left(283 \mathrm{MHz}, \mathrm{CDCl}_{3}\right): \delta=-130.91--131.03(\mathrm{~m})$.

IR (neat): $\tilde{v}=3231,3165,3005,1576,1440,1409,1251,1179,754,640 \mathrm{~cm}^{-1}$.

MS (ESI): $m / z$ (relative intensity) 381 (24), $190(100)\left[\mathrm{M}+\mathrm{H}^{+}\right], 170$ (13).

HR-MS (ESI): $\mathrm{m} / \mathrm{z}$ calcd for $\mathrm{C}_{10} \mathrm{H}_{9} \mathrm{FN}_{3}\left[\mathrm{M}+\mathrm{H}^{+}\right]$190.0780, found 190.0777 .

\section{Synthesis of $\mathrm{N}$-(o-Tolyl)pyrimidin-2-amine (69b)}<smiles>Cc1ccccc1Nc1ncccn1</smiles>

Under basic conditions:

The general procedure A was followed using 107b $(6.59 \mathrm{~g}, 61.50 \mathrm{mmol})$ and $106(3.44 \mathrm{~g}$, $30.0 \mathrm{mmol}$ ). After purification by column chromatography ( $n$-hexane/EtOAc 95:5) and

${ }^{104}$ Shaw, J. W.; Grayson, D. H.; Rozas, I. ARKIVOC 2014, 2, 161-174. 
recrystallisation $69 \mathrm{~b}(3.81 \mathrm{~g}, 69 \%)$ was obtained as a white solid. Analytical data was identical to that previously reported. ${ }^{93}$

Under acidic conditions:

A Schlenk flask was charged with $\mathrm{AlCl}_{3}(4.00 \mathrm{~g}, 30 \mathrm{mmol})$ and evacuated and purged with $\mathrm{Ar}$ three times. THF (30 mL), aniline 107b and 106 (3.44 g, $30 \mathrm{mmol})$ were added successively at $0{ }^{\circ} \mathrm{C}$. The reaction was stirred for $48 \mathrm{~h}$ at ambient temperature. The reaction was stopped with $\mathrm{H}_{2} \mathrm{O}(20 \mathrm{~mL})$, basified with $\mathrm{K}_{2} \mathrm{CO}_{3}$ and extracted with EtOAc $(100 \mathrm{~mL})$. The organic phase was washed with brine $(100 \mathrm{~mL})$, dried over $\mathrm{Na}_{2} \mathrm{SO}_{4}$ and concentrated in vacuo. After purification by column chromatography ( $n$-hexane/EtOAc 95:5) 69b (1.42 g, 26\%) was obtained as a white solid. Analytical data was identical to that previously reported.

M.p.: $88-89^{\circ} \mathrm{C}$

${ }^{1} \mathrm{H}$ NMR $\left(300 \mathrm{MHz}, \mathrm{CDCl}_{3}\right): \delta=8.39(\mathrm{~d}, J=4.8 \mathrm{~Hz}, 2 \mathrm{H}), 7.92(\mathrm{~d}, J=7.8 \mathrm{~Hz}, 1 \mathrm{H}), 7.29-7.20(\mathrm{~m}$, $2 \mathrm{H}), 7.10-7.01(\mathrm{~m}, 2 \mathrm{H}), 6.69(\mathrm{t}, J=4.8 \mathrm{~Hz}, 1 \mathrm{H}), 2.32(\mathrm{~s}, 3 \mathrm{H})$.

${ }^{13} \mathrm{C} \mathrm{NMR}\left(75 \mathrm{MHz}, \mathrm{CDCl}_{3}\right): \delta=160.8\left(\mathrm{C}_{\mathrm{q}}\right), 158.2(\mathrm{CH}), 137.3\left(\mathrm{C}_{\mathrm{q}}\right), 130.7(\mathrm{CH}), 129.6\left(\mathrm{C}_{\mathrm{q}}\right), 126.8$ $(\mathrm{CH}), 124.3(\mathrm{CH}), 122.6(\mathrm{CH}), 112.4(\mathrm{CH}), 18.2\left(\mathrm{CH}_{3}\right)$.

IR (neat): $\tilde{v}=3228,3031,2927,1579,1441,1406,1187,797,751,719 \mathrm{~cm}^{-1}$.

MS (ESI): $m / z$ (relative intensity) 208 (6), $186(100)\left[\mathrm{M}+\mathrm{H}^{+}\right], 170$ (4).

HR-MS (ESI): $\mathrm{m} / \mathrm{z}$ calcd for $\mathrm{C}_{11} \mathrm{H}_{11} \mathrm{~N}_{3}\left[\mathrm{M}+\mathrm{H}^{+}\right]$186.1031, found 186.1030 .

\section{Synthesis of $N$-(2-methoxyphenyl)pyrimidin-2-amine (69c)}<smiles>COc1ccccc1Nc1ncccn1</smiles>

The general procedure A was followed using $107 \mathrm{c}(4.93 \mathrm{~g}, 40.0 \mathrm{mmol})$ and $106(2.29 \mathrm{~g}$, $20.0 \mathrm{mmol}$ ). After purification by column chromatography ( $n$-hexane/EtOAc 85:15) and recrystallisation 69c (1.45 g, 37\%) was obtained as a white solid. Analytical data was identical to that previously reported. ${ }^{104}$

M.p.: $119-120^{\circ} \mathrm{C}$

${ }^{1} \mathbf{H}$ NMR $\left(300 \mathrm{MHz}, \mathrm{CDCl}_{3}\right): \delta=8.53-8.48(\mathrm{~m}, 1 \mathrm{H}), 8.43(\mathrm{~d}, J=4.8 \mathrm{~Hz}, 2 \mathrm{H}), 7.78(\mathrm{~s}, 1 \mathrm{H}), 7.04-$ $6.95(\mathrm{~m}, 2 \mathrm{H}), 6.92-6.87(\mathrm{~m}, 1 \mathrm{H}), 6.70(\mathrm{t}, J=4.8 \mathrm{~Hz}, 1 \mathrm{H}), 3.90(\mathrm{~s}, 3 \mathrm{H})$. 
${ }^{13} \mathrm{C} \mathrm{NMR}\left(75 \mathrm{MHz}, \mathrm{CDCl}_{3}\right): \delta=160.2\left(\mathrm{C}_{\mathrm{q}}\right), 158.0(\mathrm{CH}), 148.0\left(\mathrm{C}_{\mathrm{q}}\right), 129.3\left(\mathrm{C}_{\mathrm{q}}\right), 121.9(\mathrm{CH}), 121.0$ $(\mathrm{CH}), 118.6(\mathrm{CH}), 112.5(\mathrm{CH}), 110.1(\mathrm{CH}), 55.8\left(\mathrm{CH}_{3}\right)$.

IR (neat): $\tilde{v}=3382,2998,2836,1569,1520,1432,1405,1241,721,566 \mathrm{~cm}^{-1}$.

MS (ESI): $m / z$ (relative intensity) 224 (12), 202 (100) [M+H+ $], 187$ (7), 170 (18).

HR-MS (ESI): $\mathrm{m} / \mathrm{z}$ calcd for $\mathrm{C}_{11} \mathrm{H}_{11} \mathrm{~N}_{3} \mathrm{O}\left[\mathrm{M}+\mathrm{H}^{+}\right]$202.0980, found 202.0979.

\section{Synthesis of $N$-[2-(tert-Butyl)phenyl]pyrimidin-2-amine (69d)}<smiles>CC(C)(C)c1ccccc1Nc1ncccn1</smiles>

The general procedure A was followed using 107d $(2.98 \mathrm{~g}, 20.0 \mathrm{mmol})$ and $106(1.14 \mathrm{~g}$, $10.0 \mathrm{mmol}$ ). After purification by column chromatography ( $n$-hexane/EtOAc 95:5) and recrystallisation $69 \mathrm{~d}(1.12 \mathrm{~g}, 50 \%)$ was obtained as a white solid.

M.p.: $95-96^{\circ} \mathrm{C}$

${ }^{1} \mathbf{H}$ NMR $\left(300 \mathrm{MHz} \mathrm{CDCl}_{3}\right): \delta=8.35(\mathrm{~d}, J=4.8 \mathrm{~Hz}, 2 \mathrm{H}), 7.58(\mathrm{dd}, J=7.9,1.5 \mathrm{~Hz}, 1 \mathrm{H}), 7.45$ (dd, $J$ $=7.9,1.6 \mathrm{~Hz}, 1 \mathrm{H}$ ), 7.27 (ddd, $J=7.5,7.5,1.6 \mathrm{~Hz}, 1 \mathrm{H}$ ), 7.17 (ddd, $J=7.5,7.5,1.6 \mathrm{~Hz}, 1 \mathrm{H}$ ), 6.89 (br s, 1H), $6.64(t, J=4.8 \mathrm{~Hz}, 1 \mathrm{H}), 1.44(\mathrm{~s}, 9 \mathrm{H})$.

${ }^{13} \mathrm{C}$ NMR $\left(75 \mathrm{MHz}, \mathrm{CDCl}_{3}\right): \delta=161.5\left(\mathrm{C}_{\mathrm{q}}\right), 158.4(\mathrm{CH}), 143.8\left(\mathrm{C}_{\mathrm{q}}\right), 136.9\left(\mathrm{C}_{\mathrm{q}}\right), 128.4(\mathrm{CH}), 127.0$ $(\mathrm{CH}), 126.9(\mathrm{CH}), 125.9(\mathrm{CH}), 112.1(\mathrm{CH}), 35.0\left(\mathrm{C}_{\mathrm{q}}\right), 30.8\left(\mathrm{CH}_{3}\right)$.

IR (neat): $\tilde{v}=3211,3004,2958,2936,1570,1440,1407,1257,1088,773 \mathrm{~cm}^{-1}$.

MS (ESI): $m / z$ (relative intensity) 250 (23), $228(100)\left[\mathrm{M}+\mathrm{H}^{+}\right], 172(57)$.

HR-MS (ESI): $\mathrm{m} / \mathrm{z}$ calcd for $\mathrm{C}_{14} \mathrm{H}_{18} \mathrm{~N}_{3}\left[\mathrm{M}+\mathrm{H}^{+}\right]$228.15004, found 228.1498 .

\section{Synthesis of $N$-([1,1'-Biphenyl]-2-yl)pyrimidin-2-amine (69e)}<smiles>Pc1ccccc1Nc1ncccn1</smiles>

The general procedure A was followed using 107e $(3.48 \mathrm{~g}, 20.5 \mathrm{mmol})$ and 106 (1.14 g, $10.0 \mathrm{mmol}$ ). After purification by column chromatography ( $n$-hexane/EtOAc 9:1) and recrystallisation $69 \mathrm{e}(0.91 \mathrm{~g}, 37 \%)$ was obtained as a white solid. Analytical data was identical to that previously reported. 
M.p.: $165-166^{\circ} \mathrm{C}$

${ }^{1} \mathbf{H}$ NMR $\left(300 \mathrm{MHz}, \mathrm{CDCl}_{3}\right): \delta=8.40(\mathrm{dd}, J=8.1,0.9 \mathrm{~Hz}, 1 \mathrm{H}), 8.38(\mathrm{~d}, J=4.8 \mathrm{~Hz}, 2 \mathrm{H}), 7.50-$ $7.35(\mathrm{~m}, 6 \mathrm{H}), 7.27(\mathrm{~d}, J=8.3,1.6 \mathrm{~Hz}, 1 \mathrm{H}), 7.13(\mathrm{dd}, J=7.5,7.5,1.2 \mathrm{~Hz}, 1 \mathrm{H}), 7.08(\mathrm{br} \mathrm{s}, 1 \mathrm{H})$, $6.69(\mathrm{t}, J=4.8 \mathrm{~Hz}, 1 \mathrm{H})$.

${ }^{13} \mathrm{C}$ NMR $\left(75 \mathrm{MHz}, \mathrm{CDCl}_{3}\right): \delta=160.3\left(\mathrm{C}_{\mathrm{q}}\right), 158.1(\mathrm{CH}), 138.8\left(\mathrm{C}_{\mathrm{q}}\right), 136.4\left(\mathrm{C}_{\mathrm{q}}\right), 130.5\left(\mathrm{C}_{\mathrm{q}}\right), 129.6$ $(\mathrm{CH}), 129.2(\mathrm{CH}), 128.3(\mathrm{CH}), 127.9(\mathrm{CH}), 123.0(\mathrm{CH}), 120.6(\mathrm{CH}), 112.7(\mathrm{CH})$.

IR (neat): $\tilde{v}=3268,3225,3018,1575,1519,1433,1407,1267,738,698 \mathrm{~cm}^{-1}$.

MS (ESI): $m / z$ (relative intensity) 381 (5), 270 (7), 248 (100) $\left[\mathrm{M}+\mathrm{H}^{+}\right], 195$ (1), 178 (3).

HR-MS (ESI): $\mathrm{m} / \mathrm{z}$ calcd for $\mathrm{C}_{16} \mathrm{H}_{14} \mathrm{~N}_{3}\left[\mathrm{M}+\mathrm{H}^{+}\right]$248.1187, found 248.1185 .

\section{Synthesis of $N$-[3-(Trifluoromethyl)phenyl]pyrimidin-2-amine (69f)}<smiles>FC(F)(F)c1cccc(Nc2ncccn2)c1</smiles>

The general procedure A was followed using $107 \mathrm{f}(13.2 \mathrm{~g}, 82.0 \mathrm{mmol})$ and $106(5.58 \mathrm{~g}$, $40.0 \mathrm{mmol}$ ). After purification by column chromatography ( $n$-hexane/EtOAc 9:1) and recrystallisation $69 \mathrm{f}$ (3.54 $\mathrm{g}, 37 \%$ ) was obtained as a white solid.

M.p.: $123-124^{\circ} \mathrm{C}$

${ }^{1} \mathbf{H}$ NMR (300 MHz, CDCl $): \delta=8.47(\mathrm{~d}, J=4.8 \mathrm{~Hz}, 2 \mathrm{H}), 8.20(\mathrm{br} \mathrm{s}, 1 \mathrm{H}), 8.02(\mathrm{~s}, 1 \mathrm{H}), 7.79$ (dd, $J$ $=8.4,1.7 \mathrm{~Hz}, 1 \mathrm{H}), 7.43(\mathrm{dd}, J=8.4,7.7 \mathrm{~Hz}, 1 \mathrm{H}), 7.29$ (ddd, $J=7.7,1.5,0.8 \mathrm{~Hz}, 1 \mathrm{H}), 6.79(\mathrm{t}, J=$ $4.8 \mathrm{~Hz}, 1 \mathrm{H})$.

${ }^{13} \mathrm{C}$ NMR $\left(126 \mathrm{MHz}, \mathrm{CDCl}_{3}\right): \delta=159.9\left(\mathrm{C}_{\mathrm{q}}\right), 158.0(\mathrm{CH}), 140.2\left(\mathrm{C}_{\mathrm{q}}\right), 131.3\left(\mathrm{C}_{\mathrm{q}}, \mathrm{q},{ }^{2} \mathrm{~J}_{\mathrm{C}-\mathrm{F}}=32.4 \mathrm{~Hz}\right)$, $129.4(\mathrm{CH}), 124.2\left(\mathrm{C}_{\mathrm{q}}, \mathrm{q},{ }^{1} \mathrm{~J}_{\mathrm{C}-\mathrm{F}}=272.6 \mathrm{~Hz}\right), 122.3\left(\mathrm{CH}, \mathrm{q},{ }^{4} J_{\mathrm{C}-\mathrm{F}}=1.2 \mathrm{~Hz}\right), 119.0\left(\mathrm{CH}, \mathrm{q},{ }^{3} J_{\mathrm{C}-\mathrm{F}}=\right.$ $3.7 \mathrm{~Hz}), 116.0\left(\mathrm{CH}, \mathrm{q},{ }^{3} \mathrm{~J}_{\mathrm{C}-\mathrm{F}}=3.9 \mathrm{~Hz}\right), 113.3(\mathrm{CH})$.

${ }^{19}$ F NMR $\left(283 \mathrm{MHz}, \mathrm{CDCl}_{3}\right): \delta=-62.68(\mathrm{~s})$.

IR (neat): $\tilde{v}=3294,3119,1580,1318,1152,1102,1072,872,792,765 \mathrm{~cm}^{-1}$.

MS (ESI): $m / z$ (relative intensity) 381 (22), 240 (100) [M+H'], 220 (10), 185 (3).

HR-MS (ESI): $\mathrm{m} / \mathrm{z}$ calcd for $\mathrm{C}_{11} \mathrm{H}_{8} \mathrm{~F}_{3} \mathrm{~N}_{3}\left[\mathrm{M}+\mathrm{H}^{+}\right] 240.0748$, found 240.0745 .

\section{Synthesis of $\mathrm{N}$-(Naphthalen-2-yl)pyrimidin-2-amine (69g)}


<smiles>c1cnc(Nc2cccc3ccccc23)nc1</smiles>

The general procedure A was followed using $107 \mathrm{~g}(2.94 \mathrm{~g}, 20.5 \mathrm{mmol})$ and $106(1.14 \mathrm{~g}$, $10.0 \mathrm{mmol}$ ). After purification by column chromatography ( $n$-hexane/EtOAc 9:1) and recrystallisation $69 \mathrm{~g}(0.93 \mathrm{~g}, 42 \%)$ was obtained as a white solid. Analytical data was identical to that previously reported. ${ }^{93}$

M.p.: $147-148^{\circ} \mathrm{C}$

${ }^{1} \mathbf{H}$ NMR $\left(300 \mathrm{MHz}, \mathrm{CDCl}_{3}\right): \delta=8.59(\mathrm{br} \mathrm{s}, 1 \mathrm{H}), 8.32(\mathrm{~d}, J=4.8 \mathrm{~Hz}, 2 \mathrm{H}), 8.16-8.09(\mathrm{~m}, 1 \mathrm{H})$, $7.99(\mathrm{~d}, J=7.5 \mathrm{~Hz}, 1 \mathrm{H}), 7.95-7.86(\mathrm{~m}, 1 \mathrm{H}), 7.73(\mathrm{~d}, J=8.2 \mathrm{~Hz}, 1 \mathrm{H}), 7.60-7.45(\mathrm{~m}, 3 \mathrm{H}), 6.63$ $(\mathrm{t}, J=4.8 \mathrm{~Hz}, 1 \mathrm{H})$.

${ }^{13} \mathrm{C} \mathrm{NMR}\left(75 \mathrm{MHz}, \mathrm{CDCl}_{3}\right): \delta=161.6\left(\mathrm{C}_{\mathrm{q}}\right), 158.2(\mathrm{CH}), 134.5\left(2 * \mathrm{C}_{\mathrm{q}}\right), 128.6(\mathrm{CH}), 128.3\left(\mathrm{C}_{\mathrm{q}}\right)$, $126.0(\mathrm{CH}), 126.0(\mathrm{CH}), 125.9(\mathrm{CH}), 125.1(\mathrm{CH}), 121.9(\mathrm{CH}), 120.6(\mathrm{CH}), 112.2(\mathrm{CH})$.

IR (neat): $\tilde{v}=3230,3045,2914,1572,1529,1443,1392,1271,777,511 \mathrm{~cm}^{-1}$.

MS (ESI): $m / z$ (relative intensity) 244 (8), $222(100)\left[\mathrm{M}+\mathrm{H}^{+}\right]$.

HR-MS (ESI): $\mathrm{m} / \mathrm{z}$ calcd for $\mathrm{C}_{14} \mathrm{H}_{11} \mathrm{~N}_{3}\left[\mathrm{M}+\mathrm{H}^{+}\right]$222.1031, found 222.1024.

\section{Synthesis of 2-Chloro-4-(p-tolyl)pyrimidine (160)}<smiles>Cc1ccc(-c2ccnc(Cl)n2)cc1</smiles>

Following the reported procedure, ${ }^{105}$ 2,4-dichloropyrimidine $(2.2 \mathrm{~g}, 15 \mathrm{mmol})$ and $p$ tolylboronic acid $(1.4 \mathrm{~g}, 10 \mathrm{mmol})$ were reacted. After purification by flash column chromatography ( $n$-hexane/EtOAc 96:4) and Kugelrohr distilliation ( $1 \mathrm{mbar}, 170{ }^{\circ} \mathrm{C}$ ) 160 (1.4 g, 69\%) was obtained as a white solid.

M.p.: $102-103^{\circ} \mathrm{C}$

${ }^{1} \mathbf{H}$ NMR (300 MHz, CDCl $): \delta=8.59(\mathrm{~d}, J=5.3 \mathrm{~Hz}, 1 \mathrm{H}), 7.99(\mathrm{~d}, J=8.2 \mathrm{~Hz}, 2 \mathrm{H}), 7.61(\mathrm{~d}, J=$ $5.3 \mathrm{~Hz}, 1 \mathrm{H}), 7.31(\mathrm{~d}, J=8.2 \mathrm{~Hz}, 2 \mathrm{H}), 2.43(\mathrm{~s}, 3 \mathrm{H})$.

${ }^{13} \mathrm{C} \mathrm{NMR}\left(75 \mathrm{MHz}, \mathrm{CDCl}_{3}\right): \delta=167.3(\mathrm{CH}), 161.9\left(\mathrm{C}_{\mathrm{q}}\right), 159.7\left(\mathrm{C}_{\mathrm{q}}\right), 142.7(\mathrm{CH}), 132.4\left(\mathrm{C}_{\mathrm{q}}\right), 130.0$ (CH), $127.5(\mathrm{CH}), 114.9(\mathrm{CH}), 21.7\left(\mathrm{CH}_{3}\right)$.

${ }^{105}$ Peng, Z.-H.; Journet, M.; Humphrey, G. Org. Lett. 2008, 8, 395-398. 
IR (neat): $\tilde{v}=1566,1532,1424,1346,1176,1066,817,770,687,483 \mathrm{~cm}^{-1}$.

MS (ESI): m/z (relative intensity) 227 (7), 205 (100) [M+H'], 177 (4), 149 (5), 117 (46), 103 (14).

HR-MS (ESI): $\mathrm{m} / \mathrm{z}$ calcd for $\mathrm{C}_{11} \mathrm{H}_{10} \mathrm{ClN}_{2}\left[\mathrm{M}+\mathrm{H}^{+}\right]$205.0532, found 205.0531 .

\section{Synthesis of $\mathbf{N}$-(2-Fluorophenyl)-4-(p-tolyl)pyrimidin-2-amine (121)}<smiles>Cc1ccc(-c2ccnc(Nc3ccccc3F)n2)cc1</smiles>

A round-bottom flask was charged with 2-chloro-4-(p-tolyl)pyrimidine (160) $(819 \mathrm{mg}$, $4.0 \mathrm{mmol}), 1$,4-dioxane $(12 \mathrm{~mL}), 2$-fluoroaniline $(0.58 \mathrm{~mL}, 6.0 \mathrm{mmol})$ and trifluoroacetic acid $(3.06 \mathrm{~mL}, 40 \mathrm{mmol})$. The reaction was stirred at $80^{\circ} \mathrm{C}$ for $16 \mathrm{~h}$. The reaction was cooled to ambient temperature, solvents evaporated in vacuo, residue basified with $\mathrm{K}_{2} \mathrm{CO}_{3}$ and extracted with EtOAc threefold. The organic phases were dried over $\mathrm{Na}_{2} \mathrm{SO}_{4}$ and evaporated in vacuo. After purification by flash column chromatography ( $n$-hexane/EtOAc 9:1) 121 (703 mg, 63\%) was obtained as a white solid.

M.p.: $120-121^{\circ} \mathrm{C}$

${ }^{1} \mathbf{H}$ NMR $\left(600 \mathrm{MHz}, \mathrm{CDCl}_{3}\right): \delta=8.63(\mathrm{ddd}, J=8.4,8.2,1.5 \mathrm{~Hz}, 1 \mathrm{H}), 8.47(\mathrm{~d}, J=5.2 \mathrm{~Hz}, 1 \mathrm{H}), 7.99$ (d, $J=7.9 \mathrm{~Hz}, 2 \mathrm{H}), 7.52(\mathrm{~s}, 1 \mathrm{H}), 7.31(\mathrm{~d}, J=7.9 \mathrm{~Hz}, 2 \mathrm{H}), 7.20(\mathrm{dd}, J=7.9,7.9 \mathrm{~Hz}, 1 \mathrm{H}), 7.17(\mathrm{~d}, J$ $=5.2 \mathrm{~Hz}, 1 \mathrm{H}), 7.13(\mathrm{ddd}, J=11.4,8.2,1.3 \mathrm{~Hz}, 1 \mathrm{H}), 7.02-6.96(\mathrm{~m}, 1 \mathrm{H}), 2.44(\mathrm{~s}, 3 \mathrm{H})$.

${ }^{13} \mathrm{C}$ NMR $\left(125 \mathrm{MHz}, \mathrm{CDCl}_{3}\right): \delta=165.1\left(\mathrm{C}_{\mathrm{q}}\right), 160.1\left(\mathrm{C}_{\mathrm{q}}\right), 158.5(\mathrm{CH}), 152.5\left(\mathrm{C}_{\mathrm{q}}, \mathrm{d},{ }^{1} J_{\mathrm{C}-\mathrm{F}}=\right.$ $242.8 \mathrm{~Hz}), 141.3\left(\mathrm{C}_{\mathrm{q}}\right), 134.3\left(\mathrm{C}_{\mathrm{q}}\right), 129.7(\mathrm{CH}), 128.5\left(\mathrm{C}_{\mathrm{q}}, \mathrm{d},{ }^{2} \mathrm{~J}_{\mathrm{C}-\mathrm{F}}=10.1 \mathrm{~Hz}\right), 127.2(\mathrm{CH}), 124.4$ $\left(\mathrm{CH}, \mathrm{d},{ }^{4} J_{\mathrm{C}-\mathrm{F}}=3.1 \mathrm{~Hz}\right), 122.1\left(\mathrm{CH}, \mathrm{d},{ }^{3} J_{\mathrm{C}-\mathrm{F}}=7.0 \mathrm{~Hz}\right), 120.7(\mathrm{CH}), 114.8\left(\mathrm{CH}, \mathrm{d},{ }^{2} J_{\mathrm{C}-\mathrm{F}}=18.7 \mathrm{~Hz}\right)$, $108.7(\mathrm{CH}), 21.6\left(\mathrm{CH}_{3}\right)$.

${ }^{19}$ F NMR $\left(283 \mathrm{MHz}, \mathrm{CDCl}_{3}\right): \delta=-131.55(\mathrm{ddd}, J=9.7,7.2,4.0 \mathrm{~Hz})$.

IR (neat): $\tilde{v}=3264,3015,1537,1438,1410,1254,1181,809,748,509 \mathrm{~cm}^{-1}$.

MS (EI): m/z (relative intensity) 279 (37) [M+], 260 (100), 138 (4), 115 (8), 91 (5).

HR-MS (EI): $\mathrm{m} / \mathrm{z}$ calcd for $\mathrm{C}_{17} \mathrm{H}_{14} \mathrm{FN}_{3}\left[\mathrm{M}^{+}\right]$279.1172, found 279.1165. 


\section{Synthesis of 3-(Pyrimidin-2-yloxy)phenol (124)}<smiles>Oc1cccc(Oc2ncccn2)c1</smiles>

A round-bottom flask was charged with THF $(40 \mathrm{~mL})$, resorcinol $(11.0 \mathrm{~g}, 100 \mathrm{mmol})$, 2chloropyrimidine (106) $(2.29 \mathrm{~g}, 20 \mathrm{mmol})$ and $\mathrm{K}_{2} \mathrm{CO}_{3}(5.52 \mathrm{~g}, 40 \mathrm{mmol})$. The reaction was stirred at $50{ }^{\circ} \mathrm{C}$ for $36 \mathrm{~h}$. The crude reaction mixture was filtered through a paper filter, washed with EtOAc and solvent evaporated in vacuo. After purification by flash column chromatography ( $n$-hexane/EtOAc 1:2) 124 (382 mg , 10\%) was isolated as a pale brown solid.

M.p.: $205-206{ }^{\circ} \mathrm{C}$

${ }^{1}$ H NMR $\left(600 \mathrm{MHz}\right.$, DMSO- $\left.d_{6}\right): \delta=9.61(\mathrm{~s}, 1 \mathrm{H}), 8.63(\mathrm{~d}, J=4.8 \mathrm{~Hz}, 2 \mathrm{H}), 7.23(\mathrm{t}, J=4.8 \mathrm{~Hz}, 1 \mathrm{H})$, 7.20 (dd, $J=8.1,8.1 \mathrm{~Hz}, 1 \mathrm{H}$ ), 6.66 (ddd, $J=8.1,2.3,0.8 \mathrm{~Hz}, 1 \mathrm{H}$ ), 6.59 (ddd, $J=8.1,2.3,0.8 \mathrm{~Hz}$, $1 \mathrm{H}), 6.56(\mathrm{dd}, J=2.2,2.2 \mathrm{~Hz}, 1 \mathrm{H})$.

${ }^{13} \mathrm{C}$ NMR $\left(125 \mathrm{MHz}, \mathrm{DMSO}-d_{6}\right): \delta=164.5\left(\mathrm{C}_{\mathrm{q}}\right), 159.7(\mathrm{CH}), 158.3\left(\mathrm{C}_{\mathrm{q}}\right), 153.6\left(\mathrm{C}_{\mathrm{q}}\right), 129.8(\mathrm{CH})$, $116.7(\mathrm{CH}), 112.1(\mathrm{CH}), 111.8(\mathrm{CH}), 108.6(\mathrm{CH})$.

IR (neat): $\tilde{v}=3204,2963,2925,1579,1410,1246,1136,1074,787,638 \mathrm{~cm}^{-1}$.

MS (EI): $m / z$ (relative intensity) $188(100)\left[\mathrm{M}^{+}\right], 160$ (32), 146 (10), 133 (11), 117 (38), 93 (15).

HR-MS (EI): $\mathrm{m} / \mathrm{z}$ calcd for $\mathrm{C}_{10} \mathrm{H}_{7} \mathrm{~N}_{2} \mathrm{O}_{2}\left[\mathrm{M}^{+}\right]$188.0586, found 188.0587 .

\section{Synthesis of Trifluoroethylbromide (146)}<smiles>FC(F)(Br)CBr</smiles>

A round-bottom flask was charged with DMPU $(50 \mathrm{~mL})$, 2,2,2-trifluoroethyl 4methylbenzenesulfonate (145) (50.8 g, $200 \mathrm{mmol})$ and $\mathrm{NaBr}(61.7 \mathrm{~g}, 600 \mathrm{mmol})$. A distillation bridge with a two-necked collection flask was attached to the round flask and the reaction was stirred at $170{ }^{\circ} \mathrm{C}$ for $1.5 \mathrm{~h}$. The pure product 146 (18.3 g, 56\%) distilled directly into the collection flask. The analytical data was identical to that reported in the literature. ${ }^{106}$

${ }^{1} \mathbf{H}$ NMR $\left(300 \mathrm{MHz}, \mathrm{CDCl}_{3}\right): \delta=3.67(\mathrm{q}, J=9.0 \mathrm{~Hz}, 2 \mathrm{H})$.

${ }^{13} \mathrm{C}$ NMR $\left(125 \mathrm{MHz}, \mathrm{CDCl}_{3}\right): \delta=123.2\left(\mathrm{C}_{\mathrm{q}}, \mathrm{q},{ }^{1} \mathrm{~J}_{\mathrm{C}-\mathrm{F}}=274.7 \mathrm{~Hz}\right), 26.0\left(\mathrm{CH}_{2}, \mathrm{q},{ }^{2} \mathrm{~J}_{\mathrm{C}-\mathrm{F}}=37.7 \mathrm{~Hz}\right)$.

${ }^{19}$ F NMR $\left(283 \mathrm{MHz}, \mathrm{CDCl}_{3}\right): \delta=-68.76(\mathrm{t}, J=9.0 \mathrm{~Hz})$.

\footnotetext{
${ }^{106}$ Sigma-Aldrich Co. , http://www.sigmaaldrich.com/spectra/fnmr/FNMR003857.PDF, (accessed $22^{\text {nd }}$ of April 2016)
} 
IR (neat): $\tilde{v}=3051,2991,1431,1310,1263,1235,1125,1065,719,629 \mathrm{~cm}^{-1}$.

MS (EI): m/z (relative intensity) $162(100)\left[\mathrm{M}^{+}\right], 143$ (22), 123 (11), 93 (26), 83 (95), 79 (10), 64 (39).

HR-MS (ESI): [not available]

\subsubsection{Analytical Data for C-H Secondary Alkylation of Benzamides 59}

Synthesis of 2-Cyclobutyl-4-methyl-N-(quinolin-8-yl)benzamide (81ab)<smiles>Cc1ccc(C(=O)Nc2cccc3cccnc23)c(C2CCC2)c1</smiles>

The general procedure B was followed using 59a $(131 \mathrm{mg}, 0.50 \mathrm{mmol})$ and $80 \mathrm{~b}(67.5 \mathrm{mg}$, $1.00 \mathrm{mmol}$ ). After purification by column chromatography ( $n$-hexane/EtOAc 96:4) 81ab (132 $\mathrm{mg}, 83 \%$ ) was obtained as a white solid.

M.p.: $136-137^{\circ} \mathrm{C}$

${ }^{1} \mathbf{H}$ NMR $\left(600 \mathrm{MHz}, \mathrm{CDCl}_{3}\right): \delta=10.10(\mathrm{~s}, 1 \mathrm{H}), 8.94(\mathrm{~d}, \mathrm{~J}=7.5 \mathrm{~Hz}, 1 \mathrm{H}), 8.76(\mathrm{dd}, J=4.2,1.6 \mathrm{~Hz}$, $1 \mathrm{H}), 8.18(\mathrm{dd}, J=8.2,1.6 \mathrm{~Hz}, 1 \mathrm{H}), 7.60(\mathrm{t}, J=7.9 \mathrm{~Hz}, 1 \mathrm{H}), 7.54(\mathrm{dd}, J=8.2,1.1 \mathrm{~Hz}, 1 \mathrm{H}), 7.51(\mathrm{~d}$, $J=7.9 \mathrm{~Hz}, 1 \mathrm{H}), 7.45(\mathrm{dd}, J=8.2,4.2 \mathrm{~Hz}, 1 \mathrm{H}), 7.27(\mathrm{~s}, 1 \mathrm{H}), 7.12(\mathrm{~d}, J=7.7 \mathrm{~Hz}, 1 \mathrm{H}), 4.09$ (pent, $J$ $=8.9 \mathrm{~Hz}, 1 \mathrm{H}), 2.44(\mathrm{~s}, 3 \mathrm{H}), 2.41-2.35(\mathrm{~m}, 2 \mathrm{H}), 2.23-2.15(\mathrm{~m}, 2 \mathrm{H}), 2.00-1.90(\mathrm{~m}, 1 \mathrm{H}), 1.81-1.74$ $(\mathrm{m}, 1 \mathrm{H})$.

${ }^{13} \mathrm{C}$ NMR $\left(126 \mathrm{MHz}, \mathrm{CDCl}_{3}\right): \delta=168.8\left(\mathrm{C}_{\mathrm{q}}\right), 148.3(\mathrm{CH}), 144.3\left(\mathrm{C}_{\mathrm{q}}\right), 140.4\left(\mathrm{C}_{\mathrm{q}}\right), 138.7\left(\mathrm{C}_{\mathrm{q}}\right), 136.5$ $(\mathrm{CH}), 135.0\left(\mathrm{C}_{\mathrm{q}}\right), 133.4\left(\mathrm{C}_{\mathrm{q}}\right), 128.2\left(\mathrm{C}_{\mathrm{q}}\right), 127.9(\mathrm{CH}), 127.6(\mathrm{CH}), 127.4(\mathrm{CH}), 126.6(\mathrm{CH}), 121.8$ $(\mathrm{CH}), 121.8(\mathrm{CH}), 116.6(\mathrm{CH}), 38.0(\mathrm{CH}), 30.0\left(\mathrm{CH}_{2}\right), 21.7\left(\mathrm{CH}_{3}\right), 18.4\left(\mathrm{CH}_{2}\right)$.

IR (ATR): $\tilde{v}=3350,2970,2860,1668,1517,1481,1324,1258,827,678,598 \mathrm{~cm}^{-1}$.

MS (EI): m/z (relative intensity) 316 (46) [M+], 287 (14), 172 (86), 157 (77), 145 (100), 115 (40), 91 (20), 43 (14).

HR-MS (EI): $m / z$ calcd for $\mathrm{C}_{21} \mathrm{H}_{20} \mathrm{~N}_{2} \mathrm{O}\left[\mathrm{M}^{+}\right]$316.1576, found 316.1583 .

Synthesis of 2-Cyclopentyl-4-methyl- $N$-(quinolin-8-yl)benzamide (81ac) 
<smiles>Cc1ccc(C(=O)Nc2cccc3cccnc23)c(C2CCCC2)c1</smiles>

The general procedure B was followed using 59a (262 mg, $1.00 \mathrm{mmol}$ ) and 80c (298 mg, $2.00 \mathrm{mmol}$ ). After purification by column chromatography (n-hexane/EtOAc 97:3) 81ac (235 mg, 71\%) was obtained as a white solid.

M.p.: $121-122^{\circ} \mathrm{C}$

${ }^{1} \mathrm{H}$ NMR $\left(600 \mathrm{MHz}, \mathrm{CDCl}_{3}\right): \delta=10.13(\mathrm{~s}, 1 \mathrm{H}), 8.95(\mathrm{~d}, J=7.8 \mathrm{~Hz}, 1 \mathrm{H}), 8.76(\mathrm{dd}, \mathrm{J}=4.2,1.7 \mathrm{~Hz}$, $1 \mathrm{H}), 8.18(\mathrm{dd}, J=8.3,1.7 \mathrm{~Hz}, 1 \mathrm{H}), 7.60(\mathrm{t}, J=7.8 \mathrm{~Hz}, 1 \mathrm{H}), 7.55(\mathrm{dd}, J=7.8,1.3 \mathrm{~Hz}, 1 \mathrm{H}), 7.50(\mathrm{~d}$, $J=7.6 \mathrm{~Hz}, 1 \mathrm{H}$ ), 7.45 (dd, J = 8.3, $4.2 \mathrm{~Hz}, 1 \mathrm{H}), 7.26(\mathrm{~s}, 1 \mathrm{H}), 7.10$ (ddd, $J=7.6,1.6,0.8 \mathrm{~Hz}, 1 \mathrm{H}$ ), $3.54(\mathrm{tt}, \mathrm{J}=9.2,7.3 \mathrm{~Hz}, 1 \mathrm{H}), 2.41(\mathrm{~s}, 3 \mathrm{H}), 2.21-2.14(\mathrm{~m}, 2 \mathrm{H}), 1.83-1.78(\mathrm{~m}, 2 \mathrm{H}), 1.70-1.61(\mathrm{~m}$, $4 \mathrm{H})$.

${ }^{13} \mathrm{C}$ NMR $(126 \mathrm{MHz}, \mathrm{CDCl} 3): \delta=169.2\left(\mathrm{C}_{\mathrm{q}}\right), 148.3(\mathrm{CH}), 145.1\left(\mathrm{C}_{\mathrm{q}}\right), 140.4\left(\mathrm{C}_{\mathrm{q}}\right), 138.7\left(\mathrm{C}_{\mathrm{q}}\right), 136.5$ $(\mathrm{CH}), 135.0\left(\mathrm{C}_{\mathrm{q}}\right), 134.7\left(\mathrm{C}_{\mathrm{q}}\right), 128.2\left(\mathrm{C}_{\mathrm{q}}\right), 127.7(\mathrm{CH}), 127.6(\mathrm{CH}), 127.2(\mathrm{CH}), 126.6(\mathrm{CH}), 121.8$ $(\mathrm{CH}), 121.7(\mathrm{CH}), 116.7(\mathrm{CH}), 42.0(\mathrm{CH}), 35.6\left(\mathrm{CH}_{2}\right), 26.1\left(\mathrm{CH}_{2}\right), 21.8\left(\mathrm{CH}_{3}\right)$.

IR (ATR): $\tilde{v}=3352,2955,2865,1667,1515,1480,1322,825,761,593 \mathrm{~cm}^{-1}$.

MS (EI): $m / z$ (relative intensity) $330(35)\left[\mathrm{M}^{+}\right], 186$ (100), 169 (55), 158 (86), 143 (48), 129 (22), 115 (30), 105 (15), 91 (16).

HR-MS (ESI): $m / z$ calcd for $\mathrm{C}_{22} \mathrm{H}_{23} \mathrm{~N}_{2} \mathrm{O}\left[\mathrm{M}+\mathrm{H}^{+}\right] 331.1805$, found 331.1804.

\section{Synthesis of 2-Cyclohexyl-4-methyl-N-(quinolin-8-yl)benzamide (81ad)}<smiles>Cc1ccc(C(=O)Nc2cccc3cccnc23)c(C2CCCCC2)c1</smiles>

The general procedure B was followed using 59a $(131 \mathrm{mg}, 0.50 \mathrm{mmol})$ and $80 \mathrm{~d}(163 \mathrm{mg}$, $1.00 \mathrm{mmol}$ ). After purification by column chromatography ( $n$-hexane/EtOAc 20:1) 81ad (148 mg, 86\%) was obtained as a white solid.

M.p.: $177-178^{\circ} \mathrm{C}$.

${ }^{1} \mathbf{H}$ NMR (300 MHz, $\left.\mathrm{CDCl}_{3}\right): \delta=10.12(\mathrm{~s}, 1 \mathrm{H}), 8.94(\mathrm{dd}, J=7.3,1.1 \mathrm{~Hz}, 1 \mathrm{H}), 8.73$ (dd, $J=4.3$, $1.7 \mathrm{~Hz}, 1 \mathrm{H}), 8.15(\mathrm{dd}, J=8.3,1.7 \mathrm{~Hz}, 1 \mathrm{H}), 7.63-7.47(\mathrm{~m}, 3 \mathrm{H}), 7.42(\mathrm{dd}, J=8.3,4.3 \mathrm{~Hz}, 1 \mathrm{H})$, 
$7.23(\mathrm{~s}, 1 \mathrm{H}), 7.09(\mathrm{dd}, J=7.8,1.1 \mathrm{~Hz}, 1 \mathrm{H}), 3.14(\mathrm{tt}, J=11.7,3.3 \mathrm{~Hz}, 1 \mathrm{H}), 2.40(\mathrm{~s}, 3 \mathrm{H}), 1.99(\mathrm{~d}, J$ $=12.8 \mathrm{~Hz}, 2 \mathrm{H}), 1.83-1.70(\mathrm{~m}, 2 \mathrm{H}), 1.67-1.15(\mathrm{~m}, 6 \mathrm{H})$.

${ }^{13} \mathrm{C}$ NMR $\left(75 \mathrm{MHz}, \mathrm{CDCl}_{3}\right): \delta=168.8\left(\mathrm{C}_{\mathrm{q}}\right), 148.1(\mathrm{CH}), 146.1\left(\mathrm{C}_{\mathrm{q}}\right), 140.2\left(\mathrm{C}_{\mathrm{q}}\right), 138.5\left(\mathrm{C}_{\mathrm{q}}\right), 136.3$ $(\mathrm{CH}), 134.9\left(\mathrm{C}_{\mathrm{q}}\right), 133.7\left(\mathrm{C}_{\mathrm{q}}\right), 128.0\left(\mathrm{C}_{\mathrm{q}}\right), 127.7(\mathrm{CH}), 127.4(\mathrm{CH}), 127.3(\mathrm{CH}), 126.5(\mathrm{CH}), 121.6$ $(\mathrm{CH}), 121.6(\mathrm{CH}), 116.4(\mathrm{CH}), 40.3(\mathrm{CH}), 34.7\left(\mathrm{CH}_{2}\right), 26.7\left(\mathrm{CH}_{2}\right), 26.1\left(\mathrm{CH}_{2}\right), 21.6\left(\mathrm{CH}_{3}\right)$.

IR (neat): $\tilde{v}=3339,2935,2849,1665,1609,1264,828,691 \mathrm{~cm}^{-1}$.

MS (EI): m/z (relative intensity) 344 (43) [M+], 200 (100), 183 (83), 144 (79), 105 (35), 43 (20).

HR-MS (EI): $m / z$ calcd for $\mathrm{C}_{23} \mathrm{H}_{24} \mathrm{~N}_{2} \mathrm{O}\left[\mathrm{M}^{+}\right] 344.1889$, found 344.1888 .

\section{Synthesis of 2-Cycloheptyl-4-methyl- $N$-(quinolin-8-yl)benzamide (81ae)}<smiles>Cc1ccc(C(=O)Nc2cccc3cccnc23)c(C2CCCCCC2)c1</smiles>

The general procedure B was followed using 59a $(262 \mathrm{mg}, 1.00 \mathrm{mmol}$ ) and $80 \mathrm{e}(354 \mathrm{mg}$, $2.00 \mathrm{mmol}$ ). After purification by column chromatography ( $n$-hexane/EtOAc 97:3) 81ae (196 mg, 55\%) was obtained as a white solid.

M.p.: $157-158^{\circ} \mathrm{C}$

${ }^{1} \mathrm{H}$ NMR $\left(600 \mathrm{MHz}, \mathrm{CDCl}_{3}\right): \delta=10.12(\mathrm{~s}, 1 \mathrm{H}), 8.96(\mathrm{~d}, J=7.5 \mathrm{~Hz}, 1 \mathrm{H}), 8.75(\mathrm{dd}, J=4.3,1.5 \mathrm{~Hz}$, $1 \mathrm{H}), 8.18(\mathrm{dd}, J=8.3,1.7 \mathrm{~Hz}, 1 \mathrm{H}), 7.61(\mathrm{t}, J=7.5 \mathrm{~Hz}, 1 \mathrm{H}), 7.55(\mathrm{dd}, J=8.3,1.5 \mathrm{~Hz}, 1 \mathrm{H}), 7.49$ (d, $J=7.7 \mathrm{~Hz}, 1 \mathrm{H}), 7.45(\mathrm{dd}, J=8.3,4.3 \mathrm{~Hz}, 1 \mathrm{H}), 7.22(\mathrm{~s}, 1 \mathrm{H}), 7.09(\mathrm{~d}, J=7.7 \mathrm{~Hz}, 1 \mathrm{H}), 3.26(\mathrm{tt}, J=$ $10.4,3.4 \mathrm{~Hz}, 1 \mathrm{H}), 2.40(\mathrm{~s}, 3 \mathrm{H}), 2.07-2.01(\mathrm{~m}, 2 \mathrm{H}), 1.78-1.67(\mathrm{~m}, 4 \mathrm{H}), 1.65-1.59(\mathrm{~m}, 2 \mathrm{H}), 1.58-$ $1.48(\mathrm{~m}, 4 \mathrm{H})$.

${ }^{13} \mathrm{C} \mathrm{NMR}\left(126 \mathrm{MHz}, \mathrm{CDCl}_{3}\right): \delta=169.0\left(\mathrm{C}_{\mathrm{q}}\right), 148.4\left(\mathrm{C}_{\mathrm{q}}\right), 148.3(\mathrm{CH}), 140.5\left(\mathrm{C}_{\mathrm{q}}\right), 138.7\left(\mathrm{C}_{\mathrm{q}}\right), 136.5$ $(\mathrm{CH}), 135.1\left(\mathrm{C}_{\mathrm{q}}\right), 133.2\left(\mathrm{C}_{\mathrm{q}}\right), 128.2\left(\mathrm{C}_{\mathrm{q}}\right), 128.1(\mathrm{CH}), 127.6(\mathrm{CH}), 127.3(\mathrm{CH}), 126.5(\mathrm{CH}), 121.7$ $(\mathrm{CH}), 121.7(\mathrm{CH}), 116.7(\mathrm{CH}), 42.5(\mathrm{CH}), 37.2\left(\mathrm{CH}_{2}\right), 28.0\left(\mathrm{CH}_{2}\right), 27.5\left(\mathrm{CH}_{2}\right), 21.8\left(\mathrm{CH}_{3}\right)$.

IR (ATR): $\tilde{v}=3342,2920,2858,1667,1518,1478,1257,1133,829,689,576 \mathrm{~cm}^{-1}$.

MS (EI): m/z (relative intensity) $358(43)\left[\mathrm{M}^{+}\right], 214$ (100), 196 (44), 171 (46), 155 (52), 144 (75), 130 (30), 105 (26), 91 (16).

HR-MS (EI): $m / z$ calcd for $\mathrm{C}_{24} \mathrm{H}_{26} \mathrm{~N}_{2} \mathrm{O}\left[\mathrm{M}^{+}\right] 358.2045$, found 358.2055. 
Synthesis of 2-(exo-norborn-2-yl)-4-methyl-N-(quinolin-8-yl)benzamide (81af)<smiles>Cc1ccc(C(=O)Nc2cccc3cccnc23)c(C2CC3CCC2C3)c1</smiles>

The general procedure B was followed using 59a $(262 \mathrm{mg}, 1.00 \mathrm{mmol})$ and $80 \mathrm{f}(350 \mathrm{mg}$, $2.00 \mathrm{mmol}$ ). After purification by column chromatography ( $n$-hexane/EtOAc 97:3) 81af (231 mg, 65\%) was obtained as a white solid.

M.p.: $158-160^{\circ} \mathrm{C}$

${ }^{1} \mathbf{H}$ NMR $\left(600 \mathrm{MHz}, \mathrm{CDCl}_{3}\right): \delta=10.11(\mathrm{~s}, 1 \mathrm{H}), 8.95(\mathrm{~d}, J=7.6 \mathrm{~Hz}, 1 \mathrm{H}), 8.75(\mathrm{dd}, J=4.2,1.5 \mathrm{~Hz}$, $1 \mathrm{H}), 8.19$ (dd, $J=8.3,1.6 \mathrm{~Hz}, 1 \mathrm{H}), 7.61(\mathrm{t}, J=7.9 \mathrm{~Hz}, 1 \mathrm{H}), 7.55(\mathrm{dd}, J=8.3,1.5 \mathrm{~Hz}, 1 \mathrm{H}), 7.50(\mathrm{~d}$, $J=7.6 \mathrm{~Hz}, 1 \mathrm{H}), 7.45(\mathrm{dd}, J=8.3,4.2 \mathrm{~Hz}, 1 \mathrm{H}), 7.25(\mathrm{~s}, 1 \mathrm{H}), 7.11-7.08(\mathrm{~m}, 1 \mathrm{H}), 3.30(\mathrm{dd}, J=8.8$, $6.0 \mathrm{~Hz}, 1 \mathrm{H}), 2.51(\mathrm{~d}, J=3.2 \mathrm{~Hz}, 1 \mathrm{H}), 2.42(\mathrm{~s}, 3 \mathrm{H}), 2.30(\mathrm{~d}, J=4.2 \mathrm{~Hz}, 1 \mathrm{H}), 1.84$ (ddd $J=11.9$, 9.1, $2.3 \mathrm{~Hz}, 1 \mathrm{H}), 1.68-1.62(\mathrm{~m}, 2 \mathrm{H}), 1.53-1.47(\mathrm{~m}, 2 \mathrm{H}), 1.31(\mathrm{ddd}, \mathrm{J}=10.6,6.9,2.4 \mathrm{~Hz}, 1 \mathrm{H})$, $1.26-1.23(\mathrm{~m}, 1 \mathrm{H}), 1.21-1.17(\mathrm{~m}, 1 \mathrm{H})$.

${ }^{13} \mathrm{C} \mathrm{NMR}\left(126 \mathrm{MHz}, \mathrm{CDCl}_{3}\right): \delta=169.3\left(\mathrm{C}_{\mathrm{q}}\right), 148.2(\mathrm{CH}), 145.9\left(\mathrm{C}_{\mathrm{q}}\right), 140.1\left(\mathrm{C}_{\mathrm{q}}\right), 138.6\left(\mathrm{C}_{\mathrm{q}}\right), 136.6$ $(\mathrm{CH}), 135.0\left(\mathrm{C}_{\mathrm{q}}\right), 134.6\left(\mathrm{C}_{\mathrm{q}}\right), 128.2\left(\mathrm{C}_{\mathrm{q}}\right), 127.7(\mathrm{CH}), 127.5(\mathrm{CH}), 127.1(\mathrm{CH}), 126.2(\mathrm{CH}), 121.8$ $(\mathrm{CH}), 121.7(\mathrm{CH}), 116.8(\mathrm{CH}), 43.7(\mathrm{CH}), 42.8(\mathrm{CH}), 40.3\left(\mathrm{CH}_{2}\right), 37.1(\mathrm{CH}), 36.9\left(\mathrm{CH}_{2}\right), 30.7\left(\mathrm{CH}_{2}\right)$, $28.8\left(\mathrm{CH}_{2}\right), 21.9\left(\mathrm{CH}_{3}\right)$.

IR (ATR): $\tilde{v}=3335,2950,2869,1672,1517,1478,1324,826,688,596 \mathrm{~cm}^{-1}$.

MS (EI): m/z (relative intensity) 356 (29) $\left[\mathrm{M}^{+}\right], 212$ (100), 184 (32), 171 (25), 144 (31), 115 (24), 67 (26).

HR-MS (EI): $m / z$ calcd for $\mathrm{C}_{24} \mathrm{H}_{24} \mathrm{~N}_{2} \mathrm{O}\left[\mathrm{M}^{+}\right] 356.1889$, found 356.1890 .

\section{Synthesis of 2-(2-Adamantyl)-4-methyl-N-(quinolin-8-yl)benzamide (81ag)}<smiles>Cc1ccc(C(=O)Nc2cccc3cccnc23)c(C2C3CC4CC(C3)CC2C4)c1</smiles>

The general procedure B was followed using 59a $(262 \mathrm{mg}, 1.00 \mathrm{mmol})$ and $80 \mathrm{~g}(430 \mathrm{mg}$, $2.00 \mathrm{mmol}$ ). After purification by column chromatography ( $n$-hexane/EtOAc 96:4) 81ag (104 mg, 28\%) was obtained as a white solid. 
M.p.: $169-170^{\circ} \mathrm{C}$

${ }^{1} \mathrm{H}$ NMR $\left(600 \mathrm{MHz}, \mathrm{CDCl}_{3}\right): \delta=10.16(\mathrm{~s}, 1 \mathrm{H}), 8.91(\mathrm{~d}, J=7.4 \mathrm{~Hz}, 1 \mathrm{H}), 8.78(\mathrm{dd}, J=4.2,1.7 \mathrm{~Hz}$, $1 \mathrm{H}), 8.18(\mathrm{dd}, J=8.3,1.6 \mathrm{~Hz}, 1 \mathrm{H}), 7.59(\mathrm{dd}, J=7.9,7.9 \mathrm{~Hz}, 1 \mathrm{H}), 7.55(\mathrm{~d}, J=5.2 \mathrm{~Hz}, 1 \mathrm{H}), 7.54$ (dd, $J=7.4,1.5 \mathrm{~Hz}, 1 \mathrm{H}$ ), 7.46 (dd, $J=8.2,4.2 \mathrm{~Hz}, 1 \mathrm{H}$ ), $7.40(\mathrm{~s}, 1 \mathrm{H}), 7.12$ (d, J= 7.6 Hz, 1H), 3.92 (s, 1H), $2.43(\mathrm{~s}, 3 \mathrm{H}), 2.30(\mathrm{~s}, 2 \mathrm{H}), 1.95(\mathrm{~d}, J=12.6 \mathrm{~Hz}, 2 \mathrm{H}), 1.90(\mathrm{~s}, 1 \mathrm{H}), 1.87(\mathrm{~s}, 2 \mathrm{H}), 1.85-$ $1.81(\mathrm{~m}, 3 \mathrm{H}), 1.70(\mathrm{~s}, 2 \mathrm{H}), 1.59(\mathrm{~d}, J=12.7 \mathrm{~Hz}, 2 \mathrm{H})$.

${ }^{13} \mathrm{C} \mathrm{NMR}\left(125 \mathrm{MHz}, \mathrm{CDCl}_{3}\right): \delta=169.7\left(\mathrm{C}_{\mathrm{q}}\right), 148.3(\mathrm{CH}), 144.0\left(\mathrm{C}_{\mathrm{q}}\right), 139.8\left(\mathrm{C}_{\mathrm{q}}\right), 138.7\left(\mathrm{C}_{\mathrm{q}}\right), 136.5$ $(\mathrm{CH}), 135.2\left(\mathrm{C}_{\mathrm{q}}\right), 134.3\left(\mathrm{C}_{\mathrm{q}}\right), 129.1(\mathrm{CH}), 128.5(\mathrm{CH}), 128.2\left(\mathrm{C}_{\mathrm{q}}\right), 127.7(\mathrm{CH}), 126.2(\mathrm{CH}), 121.8$ $(\mathrm{CH}), 121.7(\mathrm{CH}), 116.6(\mathrm{CH}), 44.8(\mathrm{CH}), 39.9\left(\mathrm{CH}_{2}\right), 38.0\left(\mathrm{CH}_{2}\right), 32.7\left(\mathrm{CH}_{2}\right), 32.6(\mathrm{CH}), 28.0(\mathrm{CH})$, $27.8(\mathrm{CH}), 22.0\left(\mathrm{CH}_{3}\right)$.

IR (neat): $\tilde{v}=3342,2901,2848,1672,1517,1480,1384,1324,826,791 \mathrm{~cm}^{-1}$.

MS (EI): m/z (relative intensity) $396(23)\left[\mathrm{M}^{+}\right], 252$ (100), 234 (9), 195 (20), 181 (9), 144 (761).

HR-MS (EI): $\mathrm{m} / \mathrm{z}$ calcd for $\mathrm{C}_{27} \mathrm{H}_{28} \mathrm{~N}_{2} \mathrm{O}\left[\mathrm{M}^{+}\right]$396.2202, found 396.2212.

\section{Synthesis of 2-iso-Propyl-4-methyl- $N$-(quinolin-8-yl)benzamide (81ai)}<smiles>Cc1ccc(C(=O)Nc2cccc3cccnc23)c(C(C)C)c1</smiles>

The general procedure B was followed using 59a $(262 \mathrm{mg}, 1.00 \mathrm{mmol})$ and $80 \mathbf{i}(163 \mathrm{mg}$, $2.00 \mathrm{mmol}$ ). After purification by column chromatography ( $n$-hexane/EtOAc 97:3) 81ai (200 mg, 66\%) was obtained as a white solid.

M.p.: $118-119^{\circ} \mathrm{C}$

${ }^{1} \mathrm{H}$ NMR $\left(600 \mathrm{MHz}, \mathrm{CDCl}_{3}\right): \delta=10.14(\mathrm{~s}, 1 \mathrm{H}), 8.95(\mathrm{~d}, J=7.5 \mathrm{~Hz}, 1 \mathrm{H}), 8.75(\mathrm{dd}, J=4.2,1.6 \mathrm{~Hz}$, $1 \mathrm{H}), 8.17(\mathrm{dd}, J=8.3,1.3 \mathrm{~Hz}, 1 \mathrm{H}), 7.60(\mathrm{t}, J=7.9 \mathrm{~Hz}, 1 \mathrm{H}), 7.55(\mathrm{dd}, J=8.2,1.3 \mathrm{~Hz}, 1 \mathrm{H}), 7.50$ (d, $J=7.5 \mathrm{~Hz}, 1 \mathrm{H}$ ), 7.45 (dd, J=8.3, 4.2 Hz, 1H), $7.26(\mathrm{~s}, 1 \mathrm{H}), 7.12$ (dd, $J=7.9,0.8 \mathrm{~Hz}, 1 \mathrm{H}$ ), 3.54 (hept, $J=6.9 \mathrm{~Hz}, 1 \mathrm{H}), 2.42(\mathrm{~s}, 3 \mathrm{H}), 1.31(\mathrm{~d}, J=6.9 \mathrm{~Hz}, 6 \mathrm{H})$.

${ }^{13} \mathrm{C} \mathrm{NMR}\left(126 \mathrm{MHz}, \mathrm{CDCl}_{3}\right): \delta=169.0\left(\mathrm{C}_{\mathrm{q}}\right), 148.3(\mathrm{CH}), 147.4\left(\mathrm{C}_{\mathrm{q}}\right), 140.5\left(\mathrm{C}_{\mathrm{q}}\right), 138.7\left(\mathrm{C}_{\mathrm{q}}\right), 136.5$ $(\mathrm{CH}), 135.0\left(\mathrm{C}_{\mathrm{q}}\right), 133.8\left(\mathrm{C}_{\mathrm{q}}\right), 128.1\left(\mathrm{C}_{\mathrm{q}}\right), 127.6(\mathrm{CH}), 127.2(\mathrm{CH}), 127.1(\mathrm{CH}), 126.7(\mathrm{CH}), 121.9$ $(\mathrm{CH}), 121.8(\mathrm{CH}), 116.6(\mathrm{CH}), 30.0(\mathrm{CH}), 24.5\left(\mathrm{CH}_{3}\right), 21.8\left(\mathrm{CH}_{3}\right)$.

IR (ATR): $\tilde{v}=3338,2966,1674,1518,1325,825,686,599 \mathrm{~cm}^{-1}$.

MS (EI): m/z (relative intensity) $304(36)\left[\mathrm{M}^{+}\right], 160$ (100), 145 (67), 128 (25), 117 (21), 105 (16), 91 (19). 
HR-MS (EI): $m / z$ calcd for $\mathrm{C}_{20} \mathrm{H}_{20} \mathrm{~N}_{2} \mathrm{O}\left[\mathrm{M}^{+}\right]$304.1576, found 304.1570 .

\section{Synthesis of 2-(sec-Butyl)-4-methyl-N-(quinolin-8-yl)benzamide (81aj)}<smiles>CCC(C)c1cc(C)ccc1C(=O)Nc1cccc2cccnc12</smiles>

The general procedure B was followed using 59a $(131 \mathrm{mg}, 0.50 \mathrm{mmol})$ and $80 \mathrm{j}(137 \mathrm{mg}$, $1.00 \mathrm{mmol}$ ). After purification by column chromatography ( $n$-hexane/EtOAc 20:1) 81aj (98 mg, 62\%) was obtained as a colorless oil.

${ }^{1} \mathrm{H}$ NMR (300 MHz, $\left.\mathrm{CDCl}_{3}\right): \delta=10.10(\mathrm{~s}, 1 \mathrm{H}), 8.94(\mathrm{dd}, J=7.3,1.4 \mathrm{~Hz}, 1 \mathrm{H}), 8.73$ (dd, $J=4.3$, $1.7 \mathrm{~Hz}, 1 \mathrm{H}), 8.15(\mathrm{dd}, J=8.3,1.7 \mathrm{~Hz}, 1 \mathrm{H}), 7.61-7.51(\mathrm{~m}, 2 \mathrm{H}), 7.49(\mathrm{~d}, J=7.9 \mathrm{~Hz}, 1 \mathrm{H}), 7.42(\mathrm{dd}, J$ $=8.3,4.3 \mathrm{~Hz}, 1 \mathrm{H}$ ), $7.19(\mathrm{~s}, 1 \mathrm{H}$ ), 7.10 (ddd, $J=7.9,1.7,0.7 \mathrm{~Hz}, 1 \mathrm{H}$ ), 3.24 (tq, $J=7.2,6.9 \mathrm{~Hz}, 1 \mathrm{H}$ ), $2.40(\mathrm{~s}, 3 \mathrm{H}), 1.77-1.55(\mathrm{~m}, 2 \mathrm{H}), 1.29(\mathrm{~d}, J=6.7 \mathrm{~Hz}, 3 \mathrm{H}), 0.83(\mathrm{t}, J=7.0 \mathrm{~Hz}, 3 \mathrm{H})$.

${ }^{13} \mathrm{C}$ NMR $\left(75 \mathrm{MHz}, \mathrm{CDCl}_{3}\right): \delta=168.9\left(\mathrm{C}_{\mathrm{q}}\right), 148.2(\mathrm{CH}), 146.0\left(\mathrm{C}_{\mathrm{q}}\right), 140.2\left(\mathrm{C}_{\mathrm{q}}\right), 138.5\left(\mathrm{C}_{\mathrm{q}}\right), 136.3$ $(\mathrm{CH}), 134.9\left(\mathrm{C}_{\mathrm{q}}\right), 134.4\left(\mathrm{C}_{\mathrm{q}}\right), 127.9\left(\mathrm{C}_{\mathrm{q}}\right), 127.4(\mathrm{CH}), 127.2(\mathrm{CH}), 127.0(\mathrm{CH}), 126.5(\mathrm{CH}), 121.6$ $(\mathrm{CH}), 121.5(\mathrm{CH}), 116.4(\mathrm{CH}), 36.8(\mathrm{CH}), 31.1\left(\mathrm{CH}_{2}\right), 22.3\left(\mathrm{CH}_{3}\right), 21.6\left(\mathrm{CH}_{3}\right), 12.3\left(\mathrm{CH}_{3}\right)$.

IR (ATR): $\tilde{v}=3350,2960,2871,1671,1422,1260,919,789 \mathrm{~cm}^{-1}$.

MS (EI): m/z (relative intensity) $318(55)\left[\mathrm{M}^{+}\right], 159$ (100), 142 (46), 91 (27), 43 (8).

HR-MS (EI): $m / z$ calcd for $\mathrm{C}_{21} \mathrm{H}_{22} \mathrm{~N}_{2} \mathrm{O}\left[\mathrm{M}^{+}\right] 318.1732$, found 318.1730 .

\section{Synthesis of 2-(Hexan-2-yl)-4-methyl-N-(quinolin-8-yl)benzamide (81ak)}<smiles>CCCCC(C)c1cc(C)ccc1C(=O)Nc1cccc2cccnc12</smiles>

The general procedure B was followed using 59a $(262 \mathrm{mg}, 1.00 \mathrm{mmol})$ and 80ak $(330 \mathrm{mg}$, $2.00 \mathrm{mmol}$ ). After purification by column chromatography ( $n$-hexane/EtOAc 96:4) 81ak (181 mg, 52\%) was obtained as a clear oil.

${ }^{1} \mathbf{H}$ NMR (300 MHz, CDCl $): \delta=10.10(\mathrm{~s}, 1 \mathrm{H}), 8.94(\mathrm{~d}, J=7.3 \mathrm{~Hz}, 1 \mathrm{H}), 8.75(\mathrm{dd}, J=3.9,1.8 \mathrm{~Hz}$, $1 \mathrm{H}), 8.17(\mathrm{dd}, J=8.5,1.1 \mathrm{~Hz}, 1 \mathrm{H}), 7.64-7.51(\mathrm{~m}, 2 \mathrm{H}), 7.51-7.41(\mathrm{~m}, 2 \mathrm{H}), 7.21(\mathrm{~s}, 1 \mathrm{H}), 7.11$ $(\mathrm{d}, J=7.7 \mathrm{~Hz}, 1 \mathrm{H}), 3.40-3.21(\mathrm{~m}, 1 \mathrm{H}), 2.42(\mathrm{~s}, 3 \mathrm{H}), 1.74-1.56(\mathrm{~m}, 2 \mathrm{H}), 1.32-1.17(\mathrm{~m}, 6 \mathrm{H})$, $0.87-0.74(\mathrm{~m}, 4 \mathrm{H})$. 
${ }^{13} \mathrm{C}$ NMR $\left(75 \mathrm{MHz}, \mathrm{CDCl}_{3}\right): \delta=169.1\left(\mathrm{C}_{\mathrm{q}}\right), 148.4(\mathrm{CH}), 146.4(\mathrm{CH}), 140.4\left(\mathrm{C}_{\mathrm{q}}\right), 138.7\left(\mathrm{C}_{\mathrm{q}}\right), 136.4$ $\left(\mathrm{C}_{\mathrm{q}}\right), 135.0(\mathrm{CH}), 134.5(\mathrm{CH}), 128.1(\mathrm{CH}), 127.6\left(\mathrm{C}_{\mathrm{q}}\right), 127.4\left(\mathrm{C}_{\mathrm{q}}\right), 127.2\left(\mathrm{C}_{\mathrm{q}}\right), 126.6(\mathrm{CH}), 121.8$ $(\mathrm{CH}), 121.8(\mathrm{CH}), 116.7(\mathrm{CH}), 61.2(\mathrm{CH}), 38.3\left(\mathrm{CH}_{2}\right), 35.4\left(\mathrm{CH}_{3}\right), 30.2\left(\mathrm{CH}_{2}\right), 23.0\left(\mathrm{CH}_{2}\right), 21.8$ $\left(\mathrm{CH}_{3}\right), 14.1\left(\mathrm{CH}_{3}\right)$.

IR (neat): $\tilde{v}=3350,2958,2926,2858,1676,1521,1482,1325,1261,825 \mathrm{~cm}^{-1}$.

MS (ESI): m/z (relative intensity) 715 (64), 369 (100), 347 (76) $\left[\mathrm{M}+\mathrm{H}^{+}\right], 236$ (8), 203 (20).

HR-MS (ESI): $\mathrm{m} / \mathrm{z}$ calcd for $\mathrm{C}_{23} \mathrm{H}_{27} \mathrm{~N}_{2} \mathrm{O}\left[\mathrm{M}+\mathrm{H}^{+}\right]$347.2123, found 347.2115.

Synthesis of 4-Methyl-2-(pentan-3-yl)-N-(quinolin-8-yl)benzamide (81al)<smiles>CCC(CC)c1cc(C)ccc1C(=O)Nc1cccc2cccnc12</smiles>

The general procedure B was followed using 59a $(262 \mathrm{mg}, 1.00 \mathrm{mmol})$ and $80 \mathrm{l}(302 \mathrm{mg}$, $2.00 \mathrm{mmol})$. After purification by column chromatography ( $n$-hexane/EtOAc 97:3) 81al (126 mg, 38\%) was obtained as a white solid.

M.p.: $80-81^{\circ} \mathrm{C}$

${ }^{1} \mathbf{H}$ NMR (300 MHz, $\left.\mathrm{CDCl}_{3}\right): \delta=10.07(\mathrm{~s}, 1 \mathrm{H}), 8.94(\mathrm{dd}, J=7.3,1.7 \mathrm{~Hz}, 1 \mathrm{H}), 8.74$ (dd, $J=4.2$, $1.7 \mathrm{~Hz}, 1 \mathrm{H}$ ), 8.17 (dd, $J=8.3,1.7 \mathrm{~Hz}, 1 \mathrm{H}), 7.63-7.54(\mathrm{~m}, 2 \mathrm{H}), 7.49(\mathrm{~d}, J=7.7 \mathrm{~Hz}, 1 \mathrm{H}), 7.44$ (dd, $J=8.3,4.2 \mathrm{~Hz}, 1 \mathrm{H}), 7.15(\mathrm{~s}, 1 \mathrm{H}), 7.11(\mathrm{ddd}, J=7.7,1.7,0.6 \mathrm{~Hz}, 1 \mathrm{H}), 3.06(\mathrm{tt}, J=8.8,5.9 \mathrm{~Hz}$, $1 \mathrm{H}), 2.42(\mathrm{~s}, 3 \mathrm{H}), 1.80-1.60(\mathrm{~m}, 4 \mathrm{H}), 0.83(\mathrm{t}, J=7.4 \mathrm{~Hz}, 6 \mathrm{H})$.

${ }^{13} \mathrm{C}$ NMR $\left(125 \mathrm{MHz}, \mathrm{CDCl}_{3}\right): \delta=169.2\left(\mathrm{C}_{\mathrm{q}}\right), 148.3(\mathrm{CH}), 144.3\left(\mathrm{C}_{\mathrm{q}}\right), 140.2\left(\mathrm{C}_{\mathrm{q}}\right), 138.7\left(\mathrm{C}_{\mathrm{q}}\right), 136.4$ $(\mathrm{CH}), 135.8\left(\mathrm{C}_{\mathrm{q}}\right), 135.1\left(\mathrm{C}_{\mathrm{q}}\right), 128.1\left(\mathrm{C}_{\mathrm{q}}\right), 127.6(\mathrm{CH}), 127.5(\mathrm{CH}), 127.0(\mathrm{CH}), 126.7(\mathrm{CH}), 121.7$ $(\mathrm{CH}), 121.7(\mathrm{CH}), 116.6(\mathrm{CH}), 44.1(\mathrm{CH}), 29.6\left(\mathrm{CH}_{2}\right), 21.8\left(\mathrm{CH}_{3}\right), 12.3\left(\mathrm{CH}_{3}\right)$.

IR (neat): $\tilde{v}=3342,2959,2923,2854,1667,1519,1481,1383,1325,781 \mathrm{~cm}^{-1}$.

MS (EI): m/z (relative intensity) $332(46)\left[\mathrm{M}^{+}\right], 208$ (28), 189 (57), 173 (100), 144 (65), 130 (36).

HR-MS (EI): $\mathrm{m} / \mathrm{z}$ calcd for $\mathrm{C}_{22} \mathrm{H}_{24} \mathrm{~N}_{2} \mathrm{O}\left[\mathrm{M}^{+}\right] 332.1889$, found 332.1880 .

Synthesis of 2-(Hexan-3-yl)-4-methyl-N-(quinolin-8-yl)benzamide (81am) 
<smiles>CCC(c1cc(C)ccc1C(=O)Nc1cccc2cccnc12)C(C)C</smiles>

The general procedure B was followed using 59a $(262 \mathrm{mg}, 1.00 \mathrm{mmol})$ and $80 \mathrm{~m}(330 \mathrm{mg}$, $2.00 \mathrm{mmol}$ ). After purification by column chromatography ( $n$-hexane/EtOAc 96:4) 81am (147 $\mathrm{mg}, 42 \%)$ was obtained as a clear oil.

${ }^{1} \mathrm{H}$ NMR $\left(600 \mathrm{MHz}, \mathrm{CDCl}_{3}\right): \delta=10.06(\mathrm{~s}, 1 \mathrm{H}), 8.94(\mathrm{~d}, J=7.7 \mathrm{~Hz}, 1 \mathrm{H}), 8.74(\mathrm{dd}, J=4.2,1.5 \mathrm{~Hz}$, $1 \mathrm{H}), 8.17$ (dd, $J=8.2,1.5 \mathrm{~Hz}, 1 \mathrm{H}), 7.59$ (dd, $J=7.9,7.9 \mathrm{~Hz}, 1 \mathrm{H}), 7.54(\mathrm{~d}, J=8.2 \mathrm{~Hz}, 1 \mathrm{H}), 7.48$ (d, $J=7.7 \mathrm{~Hz}, 1 \mathrm{H}$ ), 7.44 (dd, $J=8.2,4.2 \mathrm{~Hz}, 1 \mathrm{H}), 7.16(\mathrm{~s}, 1 \mathrm{H}), 7.10(\mathrm{~d}, J=7.7 \mathrm{~Hz}, 1 \mathrm{H}), 3.13$ (ddd, $J$ $=14.6,8.7,6.0 \mathrm{~Hz}, 1 \mathrm{H}), 2.41(\mathrm{~s}, 3 \mathrm{H}), 1.74-1.57(\mathrm{~m}, 3 \mathrm{H}), 1.34-1.23(\mathrm{~m}, 2 \mathrm{H}), 1.23-1.12(\mathrm{~m}$, $1 \mathrm{H}), 0.85-0.78(\mathrm{~m}, 6 \mathrm{H})$.

${ }^{13} \mathrm{C} \mathrm{NMR}\left(125 \mathrm{MHz}, \mathrm{CDCl}_{3}\right): \delta=169.0\left(\mathrm{C}_{\mathrm{q}}\right), 148.2(\mathrm{CH}), 144.5\left(\mathrm{C}_{\mathrm{q}}\right), 140.1\left(\mathrm{C}_{\mathrm{q}}\right), 138.7\left(\mathrm{C}_{\mathrm{q}}\right), 136.3$ $(\mathrm{CH}), 135.6\left(\mathrm{C}_{\mathrm{q}}\right), 135.0\left(\mathrm{C}_{\mathrm{q}}\right), 128.1\left(\mathrm{C}_{\mathrm{q}}\right), 127.5(\mathrm{CH}), 127.4(\mathrm{CH}), 126.9(\mathrm{CH}), 126.6(\mathrm{CH}), 121.7$ $(\mathrm{CH}), 121.7(\mathrm{CH}), 116.6(\mathrm{CH}), 42.5(\mathrm{CH}), 39.4\left(\mathrm{CH}_{2}\right), 30.1\left(\mathrm{CH}_{2}\right), 21.9\left(\mathrm{CH}_{3}\right), 21.1\left(\mathrm{CH}_{2}\right), 14.6$ $\left(\mathrm{CH}_{3}\right), 12.4\left(\mathrm{CH}_{3}\right)$.

IR (neat): $\tilde{v}=3352,2958,2928,2870,1677,1521,1482,1385,1325,825 \mathrm{~cm}^{-1}$.

MS (ESI): $m / z$ (relative intensity) 715 (52), 369 (100), 347 (68) $\left[\mathrm{M}+\mathrm{H}^{+}\right], 236$ (8), $203(20)$.

HR-MS (ESI): $\mathrm{m} / \mathrm{z}$ calcd for $\mathrm{C}_{23} \mathrm{H}_{27} \mathrm{~N}_{2} \mathrm{O}\left[\mathrm{M}+\mathrm{H}^{+}\right] 347.2123$, found 347.2119.

\section{Synthesis of 4-Methyl-2-(4-phenylbutan-2-yl)-N-(quinolin-8-yl)benzamide (81an)}<smiles>Cc1ccc(C(=O)Nc2cccc3cccnc23)c(C(C)CBr)c1</smiles>

The general procedure B was followed using 59a $(262 \mathrm{mg}, 1.00 \mathrm{mmol})$ and $80 \mathrm{n}(426 \mathrm{mg}$, $2.00 \mathrm{mmol}$ ). After purification by column chromatography ( $n$-hexane/EtOAc 97:3) 81an (224 mg, 56\%) was obtained as a viscous oil.

${ }^{1} \mathbf{H}$ NMR $\left(600 \mathrm{MHz}, \mathrm{CDCl}_{3}\right): \delta=10.15(\mathrm{~s}, 1 \mathrm{H}), 8.96(\mathrm{~d}, J=7.5 \mathrm{~Hz}, 1 \mathrm{H}), 8.75(\mathrm{dd}, J=4.2,1.6 \mathrm{~Hz}$, $1 \mathrm{H}), 8.19$ (dd, $J=8.2,1.4 \mathrm{~Hz}, 1 \mathrm{H}), 7.62(\mathrm{t}, J=7.9 \mathrm{~Hz}, 1 \mathrm{H}), 7.57(\mathrm{dd}, J=8.2,1.4 \mathrm{~Hz}, 1 \mathrm{H}), 7.55$ (d, $J=7.5 \mathrm{~Hz}, 1 \mathrm{H}), 7.45(\mathrm{dd}, J=8.2,4.2 \mathrm{~Hz}, 1 \mathrm{H}), 7.28(\mathrm{~d}, J=1.6 \mathrm{~Hz}, 1 \mathrm{H}), 7.17-7.09(\mathrm{~m}, 5 \mathrm{H}), 7.07-$ $7.03(\mathrm{~m}, 1 \mathrm{H}), 3.45(\mathrm{tq}, J=6.9,6.9 \mathrm{~Hz}, 1 \mathrm{H}), 2.65$ (ddd, $J=13.7,11.0,5.5 \mathrm{~Hz}, 1 \mathrm{H}), 2.52$ (ddd, $J=$ 13.7, 11.0, $5.5 \mathrm{~Hz}, 1 \mathrm{H}), 2.45(\mathrm{~s}, 3 \mathrm{H}), 2.10-2.03(\mathrm{~m}, 1 \mathrm{H}), 1.98-1.90(\mathrm{~m}, 1 \mathrm{H}), 1.40(\mathrm{~d}, J=6.8 \mathrm{~Hz}$, $3 \mathrm{H})$. 
${ }^{13} \mathrm{C}$ NMR $\left(126 \mathrm{MHz}, \mathrm{CDCl}_{3}\right): \delta=168.9\left(\mathrm{C}_{\mathrm{q}}\right), 148.3(\mathrm{CH}), 145.8\left(\mathrm{C}_{\mathrm{q}}\right), 142.7\left(\mathrm{C}_{\mathrm{q}}\right), 140.5\left(\mathrm{C}_{\mathrm{q}}\right), 138.7$ $\left(\mathrm{C}_{\mathrm{q}}\right), 136.4(\mathrm{CH}), 134.9\left(\mathrm{C}_{\mathrm{q}}\right), 134.5\left(\mathrm{C}_{\mathrm{q}}\right), 128.4(\mathrm{CH}), 128.2(\mathrm{CH}), 128.1\left(\mathrm{C}_{\mathrm{q}}\right), 127.5(\mathrm{CH}), 127.4$ $(\mathrm{CH}), 127.2(\mathrm{CH}), 126.9(\mathrm{CH}), 125.6(\mathrm{CH}), 121.8(\mathrm{CH}), 121.7(\mathrm{CH}), 116.6(\mathrm{CH}), 40.2\left(\mathrm{CH}_{3}\right), 35.2$ (CH), $34.2\left(\mathrm{CH}_{3}\right), 23.0\left(\mathrm{CH}_{2}\right), 21.8\left(\mathrm{CH}_{2}\right)$.

IR (ATR): $\tilde{v}=3350,3025,2923,1672,1517,1454,1260,824,696,594 \mathrm{~cm}^{-1}$.

MS (EI): m/z (relative intensity) 394 (11) [M+], 303 (76), 159 (100), 145 (36), 117 (15), 91 (76).

HR-MS (ESI): $m / z$ calcd for $\mathrm{C}_{27} \mathrm{H}_{27} \mathrm{~N}_{2} \mathrm{O}\left[\mathrm{M}+\mathrm{H}^{+}\right]$395.2123, found 395.2120.

\section{Synthesis of 2-[5-(1,3-Dioxoisoindolin-2-yl)pentan-2-yl]-4-methyl-N-(quinolin-8- yl)benzamide (81ap)}<smiles>Cc1ccc(C(=O)Nc2cccc3cccnc23)c(C(C)CCCN2C(=O)c3ccccc3C2=O)c1</smiles>

The general procedure B was followed using 59a $(262 \mathrm{mg}, 1.00 \mathrm{mmol})$ and $80 \mathrm{p}(592 \mathrm{mg}$, $2.00 \mathrm{mmol}$ ). After purification by column chromatography ( $n$-hexane/EtOAc 80:20) 81ap (178 mg, 37\%) was obtained as a white solid.

M.p.: $136-137^{\circ} \mathrm{C}$

${ }^{1} \mathrm{H}$ NMR $\left(600 \mathrm{MHz}, \mathrm{CDCl}_{3}\right): \delta=10.09(\mathrm{~s}, 1 \mathrm{H}), 8.90(\mathrm{~d}, J=6.8 \mathrm{~Hz}, 1 \mathrm{H}), 8.70(\mathrm{dd}, J=4.2,1.7 \mathrm{~Hz}$, $1 \mathrm{H}), 8.15$ (dd, $J=8.3,1.7 \mathrm{~Hz}, 1 \mathrm{H}$ ), 7.77 (dd, $J=5.4,3.0 \mathrm{~Hz}, 2 \mathrm{H}$ ), $7.66(\mathrm{dd}, J=5.4,3.0 \mathrm{~Hz}, 2 \mathrm{H}$ ), $7.57(\mathrm{dd}, J=7.9,7.9 \mathrm{~Hz}, 1 \mathrm{H}), 7.52(\mathrm{dd}, J=8.3,1.3 \mathrm{~Hz}, 1 \mathrm{H}), 7.48(\mathrm{~d}, J=7.7 \mathrm{~Hz}, 1 \mathrm{H}), 7.41$ (dd, $J$ $=8.2,4.2 \mathrm{~Hz}, 1 \mathrm{H}), 7.18(\mathrm{~s}, 1 \mathrm{H}), 7.10$ (ddd, $J=7.8,1.6,0.6 \mathrm{~Hz}, 1 \mathrm{H}), 3.67-3.57(\mathrm{~m}, 2 \mathrm{H}), 3.37$ (tq, $J=7.0,6.9 \mathrm{~Hz}, 1 \mathrm{H}), 2.39(\mathrm{~s}, 3 \mathrm{H}), 1.80-1.68(\mathrm{~m}, 2 \mathrm{H}), 1.68-1.62(\mathrm{~m}, 1 \mathrm{H}), 1.59-1.51(\mathrm{~m}$, $1 \mathrm{H}), 1.30(\mathrm{~d}, J=6.9 \mathrm{~Hz}, 3 \mathrm{H})$.

${ }^{13} \mathrm{C} \mathrm{NMR}\left(125 \mathrm{MHz}, \mathrm{CDCl}_{3}\right): \delta=168.6\left(\mathrm{C}_{\mathrm{q}}\right), 168.3\left(\mathrm{C}_{\mathrm{q}}\right), 148.2(\mathrm{CH}), 145.5\left(\mathrm{C}_{\mathrm{q}}\right), 140.5\left(\mathrm{C}_{\mathrm{q}}\right), 138.6$ $\left(\mathrm{C}_{\mathrm{q}}\right), 136.3(\mathrm{CH}), 134.9\left(\mathrm{C}_{\mathrm{q}}\right), 134.3\left(\mathrm{C}_{\mathrm{q}}\right), 133.8(\mathrm{CH}), 132.2\left(\mathrm{C}_{\mathrm{q}}\right), 128.0\left(\mathrm{C}_{\mathrm{q}}\right), 127.5(\mathrm{CH}), 127.3$ $(\mathrm{CH}), 127.1(\mathrm{CH}), 126.8(\mathrm{CH}), 123.1(\mathrm{CH}), 121.7(\mathrm{CH}), 121.6(\mathrm{CH}), 116.6(\mathrm{CH}), 38.4\left(\mathrm{CH}_{2}\right), 35.6$ $\left(\mathrm{CH}_{2}\right), 35.1(\mathrm{CH}), 27.2\left(\mathrm{CH}_{2}\right), 23.1\left(\mathrm{CH}_{3}\right), 21.8\left(\mathrm{CH}_{3}\right)$.

IR (neat): $\tilde{v}=3354,2930,2861,1704,1668,1521,1482,1394,1049,717 \mathrm{~cm}^{-1}$.

MS (EI): m/z (relative intensity) 477 (34) $\left[\mathrm{M}^{+}\right], 333$ (39), 315 (32), 186 (20), 169 (66), 160 (100), $130(46)$.

HR-MS (ESI): $\mathrm{m} / \mathrm{z}$ calcd for $\mathrm{C}_{31} \mathrm{H}_{29} \mathrm{~N}_{3} \mathrm{O}_{3}\left[\mathrm{M}+\mathrm{H}^{+}\right]$478.2131, found 478.2125. 
Synthesis of 3-Cyclohexyl-2,2-dimethyl-N-(quinolin-8-yl)propanamide (101ad)<smiles>CC(C)(CC1CCCCC1)C(=O)Nc1cccc2cccnc12</smiles>

The general procedure B was followed using $62 \mathrm{a}(228 \mathrm{mg}, 1.00 \mathrm{mmol})$ and $80 \mathrm{~d}(326 \mathrm{mg}$, $2.00 \mathrm{mmol}$ ). After purification by column chromatography ( $n$-hexane/EtOAc $2: 1$ ) followed by GPC 101ad (41 mg, 13\%) was obtained as a brown oil.

${ }^{1} \mathbf{H}$ NMR $\left(600 \mathrm{MHz}, \mathrm{CDCl}_{3}\right): \delta=10.25(\mathrm{~s}, 1 \mathrm{H}), 8.82(\mathrm{dd}, J=4.2,1.7 \mathrm{~Hz}, 1 \mathrm{H}), 8.78$ (dd, $J=7.6$, $1.3 \mathrm{~Hz}, 1 \mathrm{H}$ ), $8.16(\mathrm{dd}, J=8.2,1.7 \mathrm{~Hz}, 1 \mathrm{H}), 7.53(\mathrm{dd}, J=7.9,7.9 \mathrm{~Hz}, 1 \mathrm{H}), 7.48(\mathrm{dd}, J=8.2,1.3 \mathrm{~Hz}$, $1 \mathrm{H}), 7.45(\mathrm{dd}, J=8.2,4.2 \mathrm{~Hz}, 1 \mathrm{H}), 1.72-1.66(\mathrm{~m}, 4 \mathrm{H}), 1.61-1.52(\mathrm{~m}, 3 \mathrm{H}), 1.47-1.41(\mathrm{~m}$, $1 \mathrm{H}), 1.40(\mathrm{~s}, 6 \mathrm{H}), 1.16(\mathrm{ttt}, J=12.6,12.6,3.2 \mathrm{~Hz}, 2 \mathrm{H}), 1.06(\mathrm{ttt}, J=12.6,12.6,3.2 \mathrm{~Hz}, 1 \mathrm{H}), 0.96$ $(\mathrm{ttd}, J=12.9,12.9,3.2 \mathrm{~Hz}, 2 \mathrm{H})$.

${ }^{13} \mathrm{C}$ NMR $\left(125 \mathrm{MHz}, \mathrm{CDCl}_{3}\right): \delta=177.0\left(\mathrm{C}_{\mathrm{q}}\right), 148.2(\mathrm{CH}), 138.9\left(\mathrm{C}_{\mathrm{q}}\right), 136.3(\mathrm{CH}), 134.8\left(\mathrm{C}_{\mathrm{q}}\right)$, $128.0\left(\mathrm{C}_{\mathrm{q}}\right), 127.6(\mathrm{CH}), 121.6(\mathrm{CH}), 121.2(\mathrm{CH}), 116.3(\mathrm{CH}), 49.2(\mathrm{CH}), 43.6\left(\mathrm{C}_{\mathrm{q}}\right), 35.0\left(\mathrm{CH}_{2}\right)$, $34.8\left(\mathrm{CH}_{2}\right), 26.7\left(\mathrm{CH}_{3}\right), 26.6\left(\mathrm{CH}_{2}\right), 26.5\left(\mathrm{CH}_{2}\right)$.

IR (neat): $\tilde{v}=3365,2920,2849,1678,1521,1485,1382,1324,1131,790,678 \mathrm{~cm}^{-1}$.

MS (EI): $m / z$ (relative intensity) $310(4)\left[\mathrm{M}^{+}\right], 253$ (3), 214 (36), 171 (100), 144 (52), 116 (7).

HR-MS (EI): $\mathrm{m} / \mathrm{z}$ calcd for $\mathrm{C}_{20} \mathrm{H}_{26} \mathrm{~N}_{2} \mathrm{O}\left[\mathrm{M}^{+}\right]$310.2045, found 310.2044.

\section{Mechanistic studies}

\section{Reaction of 59a under primary alkylation conditions}

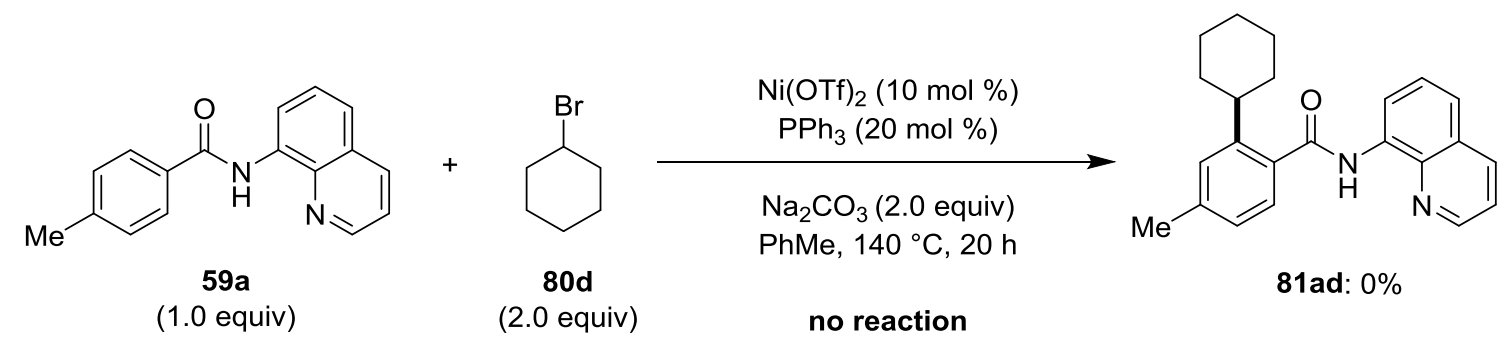


Following the reported procedure, ${ }^{52} 59$ a $(262 \mathrm{mg}, 1.0 \mathrm{mmol})$ was reacted with $80 \mathrm{~d}(326 \mathrm{mg}$, $2.0 \mathrm{mmol})$. At ambient temperature, $\mathrm{CH}_{2} \mathrm{Cl}_{2}(2.0 \mathrm{~mL})$ was added. No conversion was observed through ${ }^{1} \mathrm{H}$ NMR spectroscopic analysis of the crude reaction mixture.

\section{Intermolecular Competition Experiment between 59a and 80d}

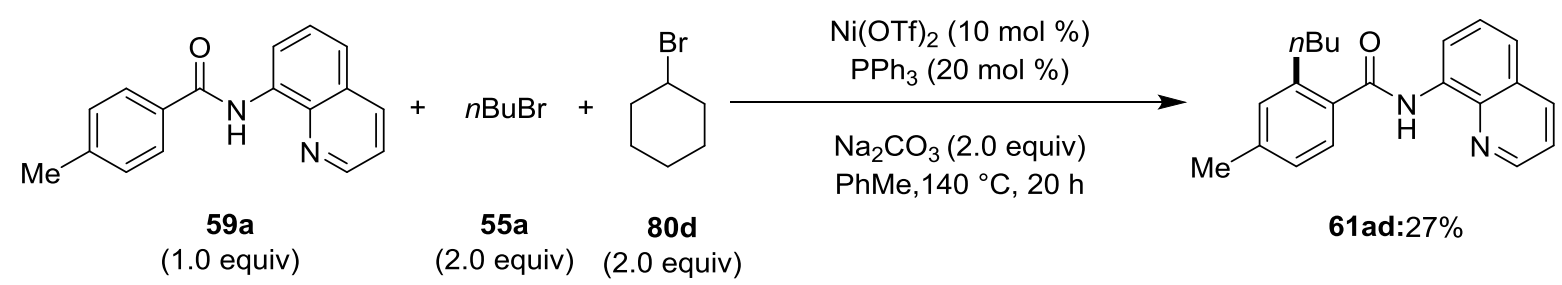

Benzamide 59a (262 mg, $1.0 \mathrm{mmol}),\left[\mathrm{Ni}(\mathrm{OTf})_{2}\right.$ ] (37 mg, $\left.10 \mathrm{~mol} \%\right), \mathrm{PPh}_{3}(53 \mathrm{mg}, 20 \mathrm{~mol} \%)$ and $\mathrm{Na}_{2} \mathrm{CO}_{3}(212 \mathrm{mg}, 2.0 \mathrm{mmol}$ ) were placed in a $25 \mathrm{~mL}$ sealed tube. The tube was evacuated and purged with Ar for three times. $n$-Butyl bromide (55a) (274 mg, $2.0 \mathrm{mmol}$ ), cyclohexyl bromide $(80 \mathrm{~d})(326 \mathrm{mg}, 2.0 \mathrm{mmol})$ and toluene $(2.0 \mathrm{~mL})$ were then added, and the mixture was stirred at $140{ }^{\circ} \mathrm{C}$ for $16 \mathrm{~h}$. At ambient temperature, $\mathrm{CH}_{2} \mathrm{Cl}_{2}(2.0 \mathrm{~mL})$ was added, and the reaction mixture was transferred into a round-bottom flask with $\mathrm{CH}_{2} \mathrm{Cl}_{2}$ and concentrated under reduced pressure. Analysis of the crude reaction mixture by GCMS gave $27 \%$ of 60 ad as the sole product.

\section{Intermolecular Competition Experiment between $80 \mathrm{k}$ and $80 \mathrm{~m}$}

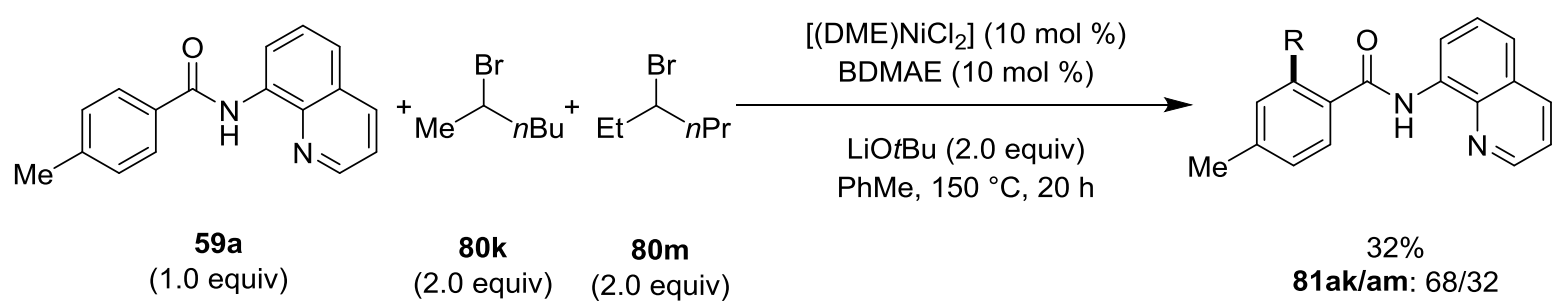

Benzamide 59a (262 mg, $1.0 \mathrm{mmol})$, [(DME) $\mathrm{NiCl}_{2}$ ] (22 mg, $\left.10 \mathrm{~mol} \%\right)$ and LiOtBu (160 mg, $2.0 \mathrm{mmol}$ ) were placed in a $25 \mathrm{~mL}$ sealed tube. The tube was evacuated and purged with $\mathrm{Ar}$ for three times. BDMAE (76 $\mu \mathrm{L}, 40 \mathrm{~mol} \%), 2$-bromo-octane (80k) (386 mg, $2.0 \mathrm{mmol}$ ), 3bromo-octane $(80 \mathrm{~m})(386 \mathrm{mg}, 2.0 \mathrm{mmol})$ and $\mathrm{PhMe}(2.0 \mathrm{~mL})$ were then added, and the mixture was stirred at $150{ }^{\circ} \mathrm{C}$ for $20 \mathrm{~h}$. At ambient temperature, $\mathrm{CH}_{2} \mathrm{Cl}_{2}(2.0 \mathrm{~mL})$ was added, and the reaction mixture was transferred into a round-bottom flask with $\mathrm{CH}_{2} \mathrm{Cl}_{2}$ and concentrated under reduced pressure. After purification by column chromatography ( $n$ - 
hexane/EtOAc 97:3) 81ak/am (55 mg, 32\%) was isolated as a mixture. The ratio of products was determined by ${ }^{1} \mathrm{H}$ NMR spectroscopy.

\subsubsection{Analytical Data for C-H Trifluoroethylation of benzamides 59}

Synthesis of 4-Fluoro-N-(quinolin-8-yl)-2-(2,2,2-trifluoroethyl)benzamide (84b) and 4Fluoro- $N$-(quinolin-8-yl)-2,6-bis(2,2,2-trifluoroethyl)benzamide (84b')<smiles>O=C(Nc1cccc2cccnc12)c1ccc(F)cc1CC(F)(F)F</smiles><smiles>O=C(Nc1cccc2cccnc12)c1c(CC(F)(F)F)cc(F)cc1C(F)(F)F</smiles>

The general procedure $\mathbf{C}$ was followed using 59b $(133 \mathrm{mg}, 0.50 \mathrm{mmol})$ and $82(210 \mathrm{mg}$, $1.00 \mathrm{mmol}$ ). After purification by column chromatography ( $n$-hexane/EtOAc 2:1), followed by GPC, 84b (41 mg, 23\%) and 84b' (16 mg, 7\%) were obtained as yellow solids.

84b:

M.p.: $95-96^{\circ} \mathrm{C}$

${ }^{1} \mathrm{H}$ NMR $\left(600 \mathrm{MHz}, \mathrm{CDCl}_{3}\right): \delta=10.30(\mathrm{~s}, 1 \mathrm{H}), 8.88$ (dd, $\left.J=7.1,1.4 \mathrm{~Hz}, 1 \mathrm{H}\right), 8.79$ (dd, $J=4.2$, $1.7 \mathrm{~Hz}, 1 \mathrm{H}), 8.19(\mathrm{dd}, J=8.3,1.6 \mathrm{~Hz}, 1 \mathrm{H}), 7.83-7.78(\mathrm{~m}, 1 \mathrm{H}), 7.62-7.59(\mathrm{~m}, 1 \mathrm{H}), 7.58(\mathrm{dd}, J$ $=8.3,1.8 \mathrm{~Hz}, 1 \mathrm{H}), 7.47(\mathrm{dd}, J=8.2,4.2 \mathrm{~Hz}, 1 \mathrm{H}), 7.21-7.18(\mathrm{~m}, 2 \mathrm{H}), 3.97(\mathrm{q}, J=10.8 \mathrm{~Hz}, 2 \mathrm{H})$.

${ }^{13} \mathrm{C}$ NMR (125 MHz, CDCl $): \delta=166.4\left(\mathrm{C}_{\mathrm{q}}\right), 163.4\left(\mathrm{C}_{\mathrm{q}}, \mathrm{d},{ }^{1} J_{\mathrm{C}-\mathrm{F}}=252.3 \mathrm{~Hz}\right), 148.4(\mathrm{CH}), 138.6$ $\left(\mathrm{C}_{\mathrm{q}}\right), 136.5(\mathrm{CH}), 134.5\left(\mathrm{C}_{\mathrm{q}}\right), 133.8\left(\mathrm{C}_{\mathrm{q}}, \mathrm{d},{ }^{4} \mathrm{~J}_{\mathrm{C}-\mathrm{F}}=3.5 \mathrm{~Hz}\right), 132.6\left(\mathrm{C}_{\mathrm{q}}, \mathrm{dq},{ }^{3} J_{\mathrm{C}-\mathrm{F}}=8.3,2.9 \mathrm{~Hz}\right), 129.8$ $\left(\mathrm{CH}, \mathrm{d},{ }^{3} J_{\mathrm{C}-\mathrm{F}}=9.2 \mathrm{~Hz}\right), 128.1\left(\mathrm{C}_{\mathrm{q}}\right), 127.4(\mathrm{CH}), 125.7\left(\mathrm{C}_{\mathrm{q}}, \mathrm{q},{ }^{1} \mathrm{~J}_{\mathrm{C}-\mathrm{F}}=276.4 \mathrm{~Hz}\right), 122.3(\mathrm{CH}), 121.9$ $(\mathrm{CH}), 119.7\left(\mathrm{CH}, \mathrm{d},{ }^{2} J_{\mathrm{C}-\mathrm{F}}=21.9 \mathrm{~Hz}\right), 116.8(\mathrm{CH}), 115.5\left(\mathrm{CH}, \mathrm{d},{ }^{2} J_{\mathrm{C}-\mathrm{F}}=20.6 \mathrm{~Hz}\right), 36.4\left(\mathrm{CH}_{2}, \mathrm{q},{ }^{2} \mathrm{~J}_{\mathrm{C}-\mathrm{F}}\right.$ $=30.7 \mathrm{~Hz})$.

${ }^{19}$ F NMR $\left(283 \mathrm{MHz}, \mathrm{CDCl}_{3}\right): \delta=-64.95(\mathrm{t}, J=10.8 \mathrm{~Hz}),-108.36--109.18(\mathrm{~m})$.

IR (neat): $\tilde{v}=3326,1663,1527,1485,1251,1142,1067,915,788,593 \mathrm{~cm}^{-1}$.

MS (EI): m/z (relative intensity) 348 (99) $\left[\mathrm{M}^{+}\right], 205$ (100), 185 (98), 171 (15), 157 (25), 144 (71), $127(35)$. 
HR-MS (EI): $\mathrm{m} / \mathrm{z}$ calcd for $\mathrm{C}_{18} \mathrm{H}_{12} \mathrm{~F}_{4} \mathrm{~N}_{2} \mathrm{O}\left[\mathrm{M}^{+}\right]$348.0886, found 348.0879.

84b':

M.p.: $181-182^{\circ} \mathrm{C}$

${ }^{1} \mathbf{H}$ NMR $\left(600 \mathrm{MHz}, \mathrm{CDCl}_{3}\right): \delta=10.14(\mathrm{~s}, 1 \mathrm{H}), 8.91(\mathrm{dd}, J=6.3,2.6 \mathrm{~Hz}, 1 \mathrm{H}), 8.75$ (dd, $J=4.2$, $1.6 \mathrm{~Hz}, 1 \mathrm{H}), 8.20(\mathrm{dd}, J=8.3,1.6 \mathrm{~Hz}, 1 \mathrm{H}), 7.63-7.61(\mathrm{~m}, 2 \mathrm{H}), 7.47(\mathrm{dd}, J=8.3,4.2 \mathrm{~Hz}, 1 \mathrm{H})$, $7.22(\mathrm{~d}, J=8.9 \mathrm{~Hz}, 2 \mathrm{H}), 3.60(\mathrm{q}, J=9.1 \mathrm{~Hz}, 4 \mathrm{H})$.

${ }^{13} \mathrm{C}$ NMR $\left(125 \mathrm{MHz}, \mathrm{CDCl}_{3}\right): \delta=165.4\left(\mathrm{C}_{\mathrm{q}}\right), 163.2\left(\mathrm{C}_{\mathrm{q}}, \mathrm{d}^{1}{ }^{1} \mathrm{~J}_{\mathrm{C}-\mathrm{F}}=249.1 \mathrm{~Hz}\right), 148.5(\mathrm{CH}), 138.5$ $\left(C_{q}\right), 136.6\left(C_{q}, d,{ }^{4} J_{C-F}=3.6 \mathrm{~Hz}\right), 136.2(\mathrm{CH}), 133.5\left(C_{q}\right), 130.4\left(C_{q}, d q,{ }^{3} J_{C-F}=8.3,2.8 \mathrm{~Hz}\right), 127.9$ $\left(\mathrm{C}_{\mathrm{q}}\right), 127.1(\mathrm{CH}), 125.1\left(\mathrm{C}_{\mathrm{q}}, \mathrm{q},{ }^{1} \mathrm{~J}_{\mathrm{C}-\mathrm{F}}=276.8 \mathrm{~Hz}\right), 122.8(\mathrm{CH}), 121.8(\mathrm{CH}), 118.1\left(\mathrm{CH}, \mathrm{d},{ }^{2} J_{\mathrm{C}-\mathrm{F}}=\right.$ $22.8 \mathrm{~Hz}), 117.1(\mathrm{CH}), 37.6\left(\mathrm{CH}_{2}, \mathrm{q}^{2}{ }^{2} \mathrm{C}-\mathrm{F}=29.5 \mathrm{~Hz}\right)$.

${ }^{19}$ F NMR $\left(283 \mathrm{MHz}, \mathrm{CDCl}_{3}\right): \delta=-64.60(\mathrm{t}, J=10.4 \mathrm{~Hz}),-109.92(\mathrm{t}, J=8.9 \mathrm{~Hz})$.

IR (neat): $\tilde{v}=3356,2924,1666,1527,1486,1280,1243,1124,1085,788 \mathrm{~cm}^{-1}$.

MS (EI): m/z (relative intensity) 430 (10) [M+ ], 287 (100), 267 (8), 247 (5), 144 (11).

HR-MS (EI): $\mathrm{m} / \mathrm{z}$ calcd for $\mathrm{C}_{20} \mathrm{H}_{13} \mathrm{~F}_{7} \mathrm{~N}_{2} \mathrm{O}\left[\mathrm{M}^{+}\right]$430.0916, found 430.0922 .

Synthesis of $N$-(Quinolin-8-yl)-2-(2,2,2-trifluoroethyl)-5-(trifluoromethyl)benzamide (84e)<smiles>O=C(Nc1cccc2cccnc12)c1cc(C(F)(F)F)ccc1CC(F)(F)F</smiles>

The general procedure $\mathbf{C}$ was followed using $59 \mathrm{e}(158 \mathrm{mg}, 0.50 \mathrm{mmol})$ and $82(210 \mathrm{mg}$, $1.00 \mathrm{mmol}$ ). After purification by column chromatography ( $n$-hexane/DCM 2:1) 84e (70 mg, $35 \%)$ was obtained as a white solid.

M.p.: $115-116^{\circ} \mathrm{C}$

${ }^{1} \mathbf{H}$ NMR (600 MHz, $\left.\mathrm{CDCl}_{3}\right): \delta=10.34(\mathrm{~s}, 1 \mathrm{H}), 8.88(\mathrm{dd}, J=5.1,3.7 \mathrm{~Hz}, 1 \mathrm{H}), 8.81$ (dd, $J=4.2$, $1.6 \mathrm{~Hz}, 1 \mathrm{H}), 8.21(\mathrm{dd}, J=8.3,1.6 \mathrm{~Hz}, 1 \mathrm{H}), 8.01(\mathrm{~s}, 1 \mathrm{H}), 7.78(\mathrm{dd}, J=7.9,1.4 \mathrm{~Hz}, 1 \mathrm{H}), 7.64-$ $7.60(\mathrm{~m}, 3 \mathrm{H}), 7.49$ (dd, $J=8.3,4.2 \mathrm{~Hz}, 1 \mathrm{H}), 3.99(\mathrm{q}, J=10.7 \mathrm{~Hz}, 2 \mathrm{H})$. 
${ }^{13} \mathrm{C}$ NMR $\left(125 \mathrm{MHz}, \mathrm{CDCl}_{3}\right): \delta=166.1\left(\mathrm{C}_{\mathrm{q}}\right), 148.7(\mathrm{CH}), 138.7\left(\mathrm{C}_{\mathrm{q}}\right), 138.6\left(\mathrm{C}_{\mathrm{q}}\right), 136.6(\mathrm{CH})$, $134.3\left(\mathrm{C}_{\mathrm{q}}\right), 133.5\left(\mathrm{C}_{\mathrm{q}}\right), 133.2(\mathrm{CH}), 131.1\left(\mathrm{C}_{\mathrm{q}}, \mathrm{q},{ }^{2} \mathrm{~J}_{\mathrm{C}-\mathrm{F}}=33.6 \mathrm{~Hz}\right), 128.2\left(\mathrm{C}_{\mathrm{q}}\right), 127.4(\mathrm{CH}), 127.3$ $\left(\mathrm{CH}, \mathrm{q},{ }^{3} \mathrm{~J}_{\mathrm{C}-\mathrm{F}}=3.4 \mathrm{~Hz}\right), 125.6\left(\mathrm{C}_{\mathrm{q}}, \mathrm{q},{ }^{1} J_{\mathrm{C}-\mathrm{F}}=277.3 \mathrm{~Hz}\right), 124.5\left(\mathrm{CH}, \mathrm{q},{ }^{3} J_{\mathrm{C}-\mathrm{F}}=3.6 \mathrm{~Hz}\right), 123.6\left(\mathrm{C}_{\mathrm{q}}, \mathrm{q}\right.$, $\left.{ }^{1} J_{\mathrm{C}-\mathrm{F}}=270.8 \mathrm{~Hz}\right), 122.6(\mathrm{CH}), 122.0(\mathrm{CH}), 117.1(\mathrm{CH}), 36.5\left(\mathrm{CH}_{2}, \mathrm{q},{ }^{2} J_{\mathrm{C}-\mathrm{F}}=30.0 \mathrm{~Hz}\right)$.

${ }^{19}$ F NMR $\left(283 \mathrm{MHz}, \mathrm{CDCl}_{3}\right): \delta=-62.79(\mathrm{~s}),-64.83(\mathrm{t}, J=10.7 \mathrm{~Hz})$.

IR (neat): $\tilde{v}=3336,1676,1527,1485,1326,1257,1114,1069,785,669 \mathrm{~cm}^{-1}$.

MS (EI): m/z (relative intensity) 398 (86) [M+], 255 (40), 235 (79), 207 (34), 171 (57), 144 (100), 130 (15).

HR-MS (EI): $\mathrm{m} / \mathrm{z}$ calcd for $\mathrm{C}_{19} \mathrm{H}_{12} \mathrm{~F}_{6} \mathrm{~N}_{2} \mathrm{O}\left[\mathrm{M}^{+}\right]$398.0854, found 398.0853 .

\section{Synthesis of 2-Fluoro-N-(quinolin-8-yl)-6-(2,2,2-trifluoroethyl)benzamide (84f)}<smiles>O=C(Nc1cccc2cccnc12)c1c(F)cccc1CC(F)(F)F</smiles>

The general procedure $C$ was followed using $59 \mathrm{f}(133 \mathrm{mg}, 0.50 \mathrm{mmol})$ and $82(210 \mathrm{mg}$, $1.00 \mathrm{mmol}$ ). After purification by column chromatography ( $n$-hexane/DCM 2:1) 84f $(51 \mathrm{mg}$, 29\%) was obtained as a white solid.

M.p.: $155-156^{\circ} \mathrm{C}$

${ }^{1} \mathrm{H}$ NMR $\left(600 \mathrm{MHz}, \mathrm{CDCl}_{3}\right): \delta=10.32(\mathrm{~s}, 1 \mathrm{H}), 8.93(\mathrm{dd}, J=6.9,1.9 \mathrm{~Hz}, 1 \mathrm{H}), 8.79(\mathrm{dd}, J=4.2$, $1.6 \mathrm{~Hz}, 1 \mathrm{H}), 8.18(\mathrm{dd}, J=8.3,1.6 \mathrm{~Hz}, 1 \mathrm{H}), 7.63-7.57(\mathrm{~m}, 2 \mathrm{H}), 7.49-7.44(\mathrm{~m}, 2 \mathrm{H}), 7.27(\mathrm{~d}, J=$ $7.5 \mathrm{~Hz}, 1 \mathrm{H}), 7.23$ (dd, $J=8.9,8.7 \mathrm{~Hz}, 1 \mathrm{H}), 3.82(\mathrm{q}, J=10.7 \mathrm{~Hz}, 2 \mathrm{H})$.

${ }^{13} \mathrm{C}$ NMR $\left(125 \mathrm{MHz}, \mathrm{CDCl}_{3}\right): \delta=162.6\left(\mathrm{C}_{\mathrm{q}}\right), 159.7\left(\mathrm{C}_{\mathrm{q}}, \mathrm{d},{ }^{1} J_{\mathrm{C}-\mathrm{F}}=248.3 \mathrm{~Hz}\right), 148.6(\mathrm{CH}), 138.7$ $\left(\mathrm{C}_{\mathrm{q}}\right), 136.5(\mathrm{CH}), 134.3\left(\mathrm{C}_{\mathrm{q}}\right), 131.5\left(\mathrm{CH}, \mathrm{d},{ }^{3} J_{\mathrm{C}-\mathrm{F}}=8.3 \mathrm{~Hz}\right), 131.4\left(\mathrm{C}_{\mathrm{q}}, \mathrm{d},{ }^{3} J_{\mathrm{C}-\mathrm{F}}=5.7 \mathrm{~Hz}\right), 128.1\left(\mathrm{C}_{\mathrm{q}}\right)$, $127.9\left(\mathrm{CH}, \mathrm{d},{ }^{4} J_{\mathrm{C}-\mathrm{F}}=2.7 \mathrm{~Hz}\right), 127.9(\mathrm{CH}), 126.4\left(\mathrm{C}_{\mathrm{q}}, \mathrm{d},{ }^{2} J_{\mathrm{C}-\mathrm{F}}=17.3 \mathrm{~Hz}\right), 125.7\left(\mathrm{C}_{\mathrm{q}}, \mathrm{q},{ }^{1} J_{\mathrm{C}-\mathrm{F}}=\right.$ $275.7 \mathrm{~Hz}), 122.5(\mathrm{CH}), 121.9(\mathrm{CH}), 117.1(\mathrm{CH}), 116.3\left(\mathrm{CH}, \mathrm{d},{ }^{2} J_{\mathrm{C}-\mathrm{F}}=22.5 \mathrm{~Hz}\right), 36.6\left(\mathrm{CH}_{2}, \mathrm{qd}\right.$, $\left.{ }^{2,4} J_{C-F}=30.7,2.2 \mathrm{~Hz}\right)$.

${ }^{19} \mathrm{~F}$ NMR $\left(283 \mathrm{MHz}, \mathrm{CDCl}_{3}\right): \delta=-65.00(\mathrm{t}, J=10.9 \mathrm{~Hz}),-113.53(\mathrm{ddd}, J=9.5,5.7,1.0 \mathrm{~Hz})$.

IR (neat): $\tilde{v}=3343,1672,1526,1486,1262,1099,1061,910,784,686 \mathrm{~cm}^{-1}$.

MS (EI): m/z (relative intensity) 348 (81) [M+], 261 (10), 205 (76), 185 (100), 171 (33), 144 (75), 127 (19). 
HR-MS (EI): $\mathrm{m} / \mathrm{z}$ calcd for $\mathrm{C}_{18} \mathrm{H}_{12} \mathrm{~F}_{4} \mathrm{~N}_{2} \mathrm{O}\left[\mathrm{M}^{+}\right]$348.0886, found 348.0884.

Synthesis of $N$-(Quinolin-8-yl)-2-(2,2,2-trifluoroethyl)thiophene-3-carboxamide (84g)<smiles>O=C(Nc1cccc2cccnc12)c1ccsc1CC(F)(F)F</smiles>

The general procedure $C$ was followed using $59 \mathrm{~g}(127 \mathrm{mg}, 0.50 \mathrm{mmol})$ and $82(210 \mathrm{mg}$, $1.00 \mathrm{mmol}$ ). After purification by column chromatography ( $n$-hexane/EtOAc $2: 1$ ) followed by GPC 84g (33 mg, 19\%) was obtained as a yellow solid.

M.p.: $128-129^{\circ} \mathrm{C}$

${ }^{1} \mathbf{H}$ NMR $\left(600 \mathrm{MHz}, \mathrm{CDCl}_{3}\right): \delta=10.48(\mathrm{~s}, 1 \mathrm{H}), 8.86(\mathrm{dd}, J=7.4,1.3 \mathrm{~Hz}, 1 \mathrm{H}), 8.83$ (dd, $J=4.2$, $1.6 \mathrm{~Hz}, 1 \mathrm{H}), 8.18(\mathrm{dd}, J=8.2,1.6 \mathrm{~Hz}, 1 \mathrm{H}), 7.60-7.54(\mathrm{~m}, 3 \mathrm{H}), 7.48(\mathrm{dd}, J=8.2,4.2 \mathrm{~Hz}, 1 \mathrm{H})$, $7.41(\mathrm{~d}, J=5.3 \mathrm{~Hz}, 1 \mathrm{H}), 4.32(\mathrm{q}, J=10.5 \mathrm{~Hz}, 2 \mathrm{H})$.

${ }^{13} \mathrm{C} \mathrm{NMR}\left(125 \mathrm{MHz}, \mathrm{CDCl}_{3}\right): \delta=161.9\left(\mathrm{C}_{\mathrm{q}}\right), 148.4(\mathrm{CH}), 138.7\left(\mathrm{C}_{\mathrm{q}}\right), 136.70\left(\mathrm{C}_{\mathrm{q}}, \mathrm{q},{ }^{3} \mathrm{~J}_{\mathrm{C}-\mathrm{F}}=3.6 \mathrm{~Hz}\right)$, $136.5(\mathrm{CH}), 135.6\left(\mathrm{C}_{\mathrm{q}}\right), 134.4\left(\mathrm{C}_{\mathrm{q}}\right), 128.1\left(\mathrm{C}_{\mathrm{q}}\right), 127.5(\mathrm{CH}), 126.3(\mathrm{CH}), 125.7(\mathrm{CH}), 125.1\left(\mathrm{C}_{\mathrm{q}}, \mathrm{q}\right.$, $\left.{ }^{1} J_{\mathrm{C}-\mathrm{F}}=275.8 \mathrm{~Hz}\right), 122.0(\mathrm{CH}), 121.8(\mathrm{CH}), 116.7(\mathrm{CH}), 32.9\left(\mathrm{CH}_{2}, \mathrm{q},{ }^{2} \mathrm{~J}_{\mathrm{C}-\mathrm{F}}=32.3 \mathrm{~Hz}\right)$.

${ }^{19}$ F NMR $\left(283 \mathrm{MHz}, \mathrm{CDCl}_{3}\right): \delta=-65.70(\mathrm{t}, J=10.5 \mathrm{~Hz})$.

IR (neat): $\tilde{v}=3363,3096,1661,1540,1524,1355,1248,1137,789,654 \mathrm{~cm}^{-1}$.

MS (EI): m/z (relative intensity) $336(42)\left[\mathrm{M}^{+}\right], 296$ (17), 193 (39), 173 (41), 144 (100), 115 (9).

HR-MS (EI): $\mathrm{m} / \mathrm{z}$ calcd for $\mathrm{C}_{16} \mathrm{H}_{11} \mathrm{~F}_{3} \mathrm{~N}_{2} \mathrm{OS}\left[\mathrm{M}^{+}\right]$336.0544, found 336.0546.

\subsubsection{Analytical Data for C-H Secondary Alkylation of $N$-(2-Pyrimidyl)anilines 69}

Synthesis of $\boldsymbol{N}$-(2-Cyclobutyl-6-fluorophenyl)pyrimidin-2-amine (86ab)<smiles>Fc1cccc(C2CCC2)c1Nc1ncccn1</smiles> 
The general procedure D1 was followed using substrate 69a (95 mg, $0.5 \mathrm{mmol}$ ), bromide 80b (135 mg, $1.0 \mathrm{mmol})$, [(DME) $\left.\mathrm{NiCl}_{2}\right](2.8 \mathrm{mg}, 2.5 \mathrm{~mol} \%)$ and DtBEDA (5.5 $\left.\mu \mathrm{L}, 5.0 \mathrm{~mol} \%\right)$ at $100{ }^{\circ} \mathrm{C}$. Isolation by column chromatography ( $n$-hexane/EtOAc: $\left.9 / 1\right)$ yielded 86ab (108 mg, $89 \%)$ as a white solid.

M.p.: $121-122^{\circ} \mathrm{C}$

${ }^{1} \mathrm{H}$ NMR $\left(600 \mathrm{MHz}, \mathrm{CDCl}_{3}\right): \delta=8.33(\mathrm{~d}, J=4.8 \mathrm{~Hz}, 2 \mathrm{H}), 7.24(\mathrm{ddd}, J=8.0,8.0,5.6 \mathrm{~Hz}, 1 \mathrm{H}), 7.14$ (d, $J=7.8 \mathrm{~Hz}, 1 \mathrm{H}$ ), 7.01 (ddd, $J=9.3,7.8,0.8 \mathrm{~Hz}, 1 \mathrm{H}), 6.94(\mathrm{~s}, 1 \mathrm{H}), 6.65(\mathrm{t}, J=4.8 \mathrm{~Hz}, 1 \mathrm{H}$ ), 3.70 $(p, J=8.9 \mathrm{~Hz}, 1 \mathrm{H}), 2.31-2.23(\mathrm{~m}, 2 \mathrm{H}), 2.16-2.08(\mathrm{~m}, 2 \mathrm{H}), 1.99-1.89(\mathrm{~m}, 1 \mathrm{H}), 1.85-1.75(\mathrm{~m}$, 1H).

${ }^{13} \mathrm{C} \mathrm{NMR}\left(125 \mathrm{MHz}, \mathrm{CDCl}_{3}\right): \delta=161.6\left(\mathrm{C}_{\mathrm{q}}\right), 158.6\left(\mathrm{C}_{\mathrm{q}},{ }^{1} J_{\mathrm{C}-\mathrm{F}}=247.6 \mathrm{~Hz}\right), 158.3(\mathrm{CH}), 145.4\left(\mathrm{C}_{\mathrm{q}}\right)$, $127.5\left(\mathrm{CH},{ }^{3} \mathrm{~J}_{\mathrm{C}-\mathrm{F}}=8.6 \mathrm{~Hz}\right), 123.9\left(\mathrm{C}_{\mathrm{q}},{ }^{2} J_{\mathrm{C}-\mathrm{F}}=12.8 \mathrm{~Hz}\right), 122.2\left(\mathrm{CH},{ }^{4} \mathrm{~J}_{\mathrm{C}-\mathrm{F}}=3.0 \mathrm{~Hz}\right), 113.6\left(\mathrm{CH}, \mathrm{d},{ }^{2} \mathrm{~J}_{\mathrm{C}-\mathrm{F}}\right.$ $=20.9 \mathrm{~Hz}), 112.2(\mathrm{CH}), 37.0\left(\mathrm{CH},{ }^{4} J_{\mathrm{C}-\mathrm{F}}=2.4 \mathrm{~Hz}\right), 29.3\left(\mathrm{CH}_{2}\right), 18.6\left(\mathrm{CH}_{2}\right)$.

${ }^{19}$ F NMR $\left(283 \mathrm{MHz}, \mathrm{CDCl}_{3}\right): \delta=-120.6(\mathrm{dd}, J=9.6,5.5 \mathrm{~Hz})$.

IR (neat): $\tilde{v}=3328,2974,2934,1582,1471,1446,1268,782,644,496 \mathrm{~cm}^{-1}$.

MS (EI): m/z (relative intensity) $243(54)\left[\mathrm{M}^{+}\right], 214(80), 196$ (100), 188 (35), 148(9), 135 (10), $107(11)$

HR-MS (EI): $m / z$ calcd for $\mathrm{C}_{14} \mathrm{H}_{14} \mathrm{FN}_{3}\left[\mathrm{M}^{+}\right]$243.1172, found 243.1166.

Synthesis of $\mathbf{N}$-(2-Cyclopentyl-6-fluorophenyl)pyrimidin-2-amine (86ac)<smiles>Fc1cccc(C2CCCC2)c1Nc1ncccn1</smiles>

The general procedure D1 was followed using substrate 69a $(189 \mathrm{mg}, 1.0 \mathrm{mmol}$ ) and bromide $80 \mathrm{c}(298 \mathrm{mg}, 2.0 \mathrm{mmol})$. Isolation by column chromatography ( $n$-hexane/EtOAc: $9 / 1$ ) yielded $86 \mathrm{ac}$ ( $230 \mathrm{mg}, 90 \%)$ as a white solid.

M.p.: $117-118^{\circ} \mathrm{C}$ 
${ }^{1} \mathrm{H}$ NMR $\left(600 \mathrm{MHz}, \mathrm{CDCl}_{3}\right): \delta=8.33(\mathrm{~d}, J=4.8 \mathrm{~Hz}, 2 \mathrm{H}), 7.23(\mathrm{ddd}, J=8.0,8.0,5.6 \mathrm{~Hz}, 1 \mathrm{H}), 7.15$ $(\mathrm{d}, J=7.9 \mathrm{~Hz}, 1 \mathrm{H}), 6.99$ (ddd, $J=9.5,8.0,1.4 \mathrm{~Hz}, 1 \mathrm{H}), 6.95(\mathrm{~s}, 1 \mathrm{H}), 6.65(\mathrm{t}, J=4.8 \mathrm{~Hz}, 1 \mathrm{H}), 3.27$ $(p, J=8.3 \mathrm{~Hz}, 1 \mathrm{H}), 2.05-1.98(\mathrm{~m}, 2 \mathrm{H}), 1.82-1.74(\mathrm{~m}, 2 \mathrm{H}), 1.66-1.53(\mathrm{~m}, 4 \mathrm{H})$.

${ }^{13} \mathrm{C} \mathrm{NMR}\left(125 \mathrm{MHz}, \mathrm{CDCl}_{3}\right): \delta=162.0\left(\mathrm{C}_{\mathrm{q}}\right), 158.9\left(\mathrm{C}_{\mathrm{q}},{ }^{1} J_{\mathrm{C}-\mathrm{F}}=247.5 \mathrm{~Hz}\right), 158.4(\mathrm{CH}), 146.8\left(\mathrm{C}_{\mathrm{q}}\right)$, $128.0\left(\mathrm{CH},{ }^{3} J_{\mathrm{C}-\mathrm{F}}=9.0 \mathrm{~Hz}\right), 124.5\left(\mathrm{C}_{\mathrm{q}},{ }^{2} \mathrm{~J}_{\mathrm{C}-\mathrm{F}}=12.6 \mathrm{~Hz}\right), 122.0\left(\mathrm{CH}, \mathrm{d},{ }^{4} J_{\mathrm{C}-\mathrm{F}}=3.4 \mathrm{~Hz}\right), 113.3\left(\mathrm{CH},{ }^{2} J_{\mathrm{C}-\mathrm{F}}\right.$ $=20.3 \mathrm{~Hz}), 112.2(\mathrm{CH}), 40.5\left(\mathrm{CH},{ }^{4} J_{\mathrm{C}-\mathrm{F}}=2.3 \mathrm{~Hz}\right), 34.2\left(\mathrm{CH}_{2}\right), 25.8\left(\mathrm{CH}_{2}\right)$.

${ }^{19}$ F NMR $\left(283 \mathrm{MHz}, \mathrm{CDCl}_{3}\right): \delta=-119.3(\mathrm{dd}, J=9.5,5.5 \mathrm{~Hz})$.

IR (neat): $\tilde{v}=3216,2953,2865,1578,1444,1405,1247,789,641 \mathrm{~cm}^{-1}$.

MS (EI): $m / z$ (relative intensity) $257(51)\left[\mathrm{M}^{+}\right], 241$ (25), 188 (100), 107 (12).

HR-MS (EI): $m / z$ calcd for $\mathrm{C}_{15} \mathrm{H}_{16} \mathrm{FN}_{3}\left[\mathrm{M}^{+}\right] 257.1328$, found 257.1320 .

\section{Synthesis of $\boldsymbol{N}$-(2-Cyclohexyl-6-fluorophenyl)pyrimidin-2-amine (86ad)}<smiles>Fc1cccc(C2CCCCC2)c1Nc1ncccn1</smiles>

The general procedure D1 was followed using substrate 69a $(189 \mathrm{mg}, 1.0 \mathrm{mmol}$ ) and bromide $80 \mathrm{~d}(246 \mu \mathrm{L}, 2.0 \mathrm{mmol})$. Isolation by column chromatography ( $n$-hexane/EtOAc: $10 / 1 \rightarrow 8 / 1$ ) yielded $86 \mathrm{ad}$ ( $270 \mathrm{mg}, 98 \%$ ) as a yellow solid.

The general procedure D3 was followed using substrate 69a $(189 \mathrm{mg}, 1.0 \mathrm{mmol}$ ) and bromide $80 \mathrm{~d}(246 \mu \mathrm{L}, 2.0 \mathrm{mmol})$ at $100{ }^{\circ} \mathrm{C}$. Isolation by column chromatography ( $n$ hexane/EtOAc: $10 / 1 \rightarrow 8 / 1$ ) yielded $86 \mathrm{ad}(264 \mathrm{mg}, 97 \%$ ) as a yellow solid.

M.p.: $93-94^{\circ} \mathrm{C}$.

${ }^{1} \mathbf{H}$ NMR $\left(500 \mathrm{MHz} \mathrm{CDCl}_{3}\right) \delta=8.31(\mathrm{~d}, J=4.8 \mathrm{~Hz}, 2 \mathrm{H}), 7.21$ (ddd, $\left.J=8.0,8.0,4.0 \mathrm{~Hz}, 1 \mathrm{H}\right), 7.10$ (d, $J=7.9 \mathrm{~Hz}, 1 \mathrm{H}$ ), 6.97 (ddd, $J=9.6,8.2,1.3 \mathrm{~Hz}, 1 \mathrm{H}), 6.85(\mathrm{~s}, 1 \mathrm{H}), 6.63(\mathrm{t}, J=4.8 \mathrm{~Hz}, 1 \mathrm{H}$ ), 2.85-2.78 $(\mathrm{m}, 1 \mathrm{H}), 1.83-1.73(\mathrm{~m}, 4 \mathrm{H}), 1.72-1.65(\mathrm{~m}, 1 \mathrm{H}), 1.43-1.33(\mathrm{~m}, 2 \mathrm{H}), 1.33-1.15(\mathrm{~m}$, $3 \mathrm{H})$. 
${ }^{13} \mathrm{C} \mathrm{NMR}\left(125 \mathrm{MHz}, \mathrm{CDCl}_{3}\right) \delta=161.9\left(\mathrm{C}_{\mathrm{q}}\right), 158.6\left(\mathrm{C}_{\mathrm{q}},{ }^{1} \mathrm{~J}_{\mathrm{C}-\mathrm{F}}=248.0 \mathrm{~Hz}\right), 158.2(\mathrm{CH}), 147.5\left(\mathrm{C}_{\mathrm{q}}\right)$, $127.8\left(\mathrm{CH},{ }^{3} \mathrm{~J}_{\mathrm{C}-\mathrm{F}}=8.6 \mathrm{~Hz}\right), 123.6\left(\mathrm{C}_{\mathrm{q}},{ }^{2} \mathrm{~J}_{\mathrm{C}-\mathrm{F}}=12.4 \mathrm{~Hz}\right), 122.0\left(\mathrm{CH},{ }^{4} \mathrm{~J}_{\mathrm{C}-\mathrm{F}}=3.3 \mathrm{~Hz}\right), 113.2\left(\mathrm{CH},{ }^{2} J_{\mathrm{C}-\mathrm{F}}=\right.$ $20.8 \mathrm{~Hz}), 112.1(\mathrm{CH}), 38.8\left(\mathrm{CH},{ }^{4} \mathrm{~J}_{\mathrm{C}-\mathrm{F}}=2.1 \mathrm{~Hz}\right), 33.7\left(\mathrm{CH}_{2}\right), 26.8\left(\mathrm{CH}_{2}\right), 26.1\left(\mathrm{CH}_{2}\right)$.

${ }^{19}$ F NMR $\left(282 \mathrm{MHz}, \mathrm{CDCl}_{3}\right) \delta=-118.83(\mathrm{dd}, J=9.8,5.4 \mathrm{~Hz})$.

IR (neat): $\tilde{v}=3224,2935,2851,1582,1523,1446,1413,1256,958,776,641 \mathrm{~cm}^{-1}$.

MS (EI) $\mathrm{m} / z$ (relative intensity) $271(60)\left[\mathrm{M}^{+}\right], 188(100), 170(5)$.

HR-MS (EI) $m / z$ calcd for $\mathrm{C}_{16} \mathrm{H}_{18} \mathrm{FN}_{3}\left[\mathrm{M}^{+}\right]$271.1485, found 271.1486.

\section{Synthesis of $\mathrm{N}$-(2-Cycloheptyl-6-fluorophenyl)pyrimidin-2-amine (86ae)}<smiles>Fc1cccc(C2CCCCCC2)c1Nc1ncccn1</smiles>

The general procedure D1 was followed using substrate 69a (189 mg, $1.0 \mathrm{mmol}$ ) and bromide $80 \mathrm{e}$ ( $354 \mathrm{mg}, 2.0 \mathrm{mmol}$ ). Isolation by column chromatography ( $n$-hexane/EtOAc: 9/1) yielded $86 a e(273 \mathrm{mg}, 96 \%)$ as a white solid.

M.p.: $103-104{ }^{\circ} \mathrm{C}$

${ }^{1} \mathbf{H}$ NMR $\left(600 \mathrm{MHz}, \mathrm{CDCl}_{3}\right): \delta=8.31(\mathrm{~d}, J=4.8 \mathrm{~Hz}, 2 \mathrm{H}), 7.48(\mathrm{~s}, 1 \mathrm{H}), 7.22$ (ddd, $J=8.2,8.2$, $5.6 \mathrm{~Hz}, 1 \mathrm{H}), 7.11(\mathrm{~d}, J=7.9 \mathrm{~Hz}, 1 \mathrm{H}), 6.98(\mathrm{ddd}, J=9.6,8.2,1.4 \mathrm{~Hz}, 1 \mathrm{H}), 6.62(\mathrm{t}, J=4.8 \mathrm{~Hz}, 1 \mathrm{H})$, $3.02(\mathrm{tt}, J=10.6,3.4 \mathrm{~Hz}, 1 \mathrm{H}), 1.90-1.83(\mathrm{~m}, 2 \mathrm{H}), 1.77-1.70(\mathrm{~m}, 2 \mathrm{H}), 1.66-1.59(\mathrm{~m}, 4 \mathrm{H}), 1.58-$ $1.51(\mathrm{~m}, 2 \mathrm{H}), 1.46-1.37(\mathrm{~m}, 2 \mathrm{H})$.

${ }^{13} \mathrm{C}$ NMR $\left(125 \mathrm{MHz}, \mathrm{CDCl}_{3}\right): \delta=162.1\left(\mathrm{C}_{\mathrm{q}}\right), 158.8\left(\mathrm{C}_{\mathrm{q}},{ }^{1} J_{\mathrm{C}-\mathrm{F}}=249.9 \mathrm{~Hz}\right), 158.3(\mathrm{CH}), 149.8\left(\mathrm{C}_{\mathrm{q}}\right)$, $128.0\left(\mathrm{CH},{ }^{3} \mathrm{~J}_{\mathrm{C}-\mathrm{F}}=8.8 \mathrm{~Hz}\right), 123.3\left(\mathrm{C}_{\mathrm{q}},{ }^{2} \mathrm{~J}_{\mathrm{C}-\mathrm{F}}=12.5 \mathrm{~Hz}\right), 122.2\left(\mathrm{CH},{ }^{4} \mathrm{~J}_{\mathrm{C}-\mathrm{F}}=3.0 \mathrm{~Hz}\right), 113.0\left(\mathrm{CH},{ }^{2} \mathrm{~J}_{\mathrm{C}-\mathrm{F}}=\right.$ $21.1 \mathrm{~Hz}), 112.0(\mathrm{CH}), 40.8\left(\mathrm{CH},{ }^{4} J_{\mathrm{C}-\mathrm{F}}=2.1 \mathrm{~Hz}\right), 36.0\left(\mathrm{CH}_{2}\right), 27.9\left(\mathrm{CH}_{2}\right), 27.5\left(\mathrm{CH}_{2}\right)$.

${ }^{19}$ F NMR $\left(283 \mathrm{MHz}, \mathrm{CDCl}_{3}\right): \delta=-119.0$ (ddd, $\left.J=9.4,5.5,1.0 \mathrm{~Hz}\right)$.

IR (neat): $\tilde{v}=3227,2923,2850,1580,1527,1446,1408,1261,970,784 \mathrm{~cm}^{-1}$.

MS (EI): m/z (relative intensity) 285 (58) $\left[\mathrm{M}^{+}\right], 242$ (24), 228 (34), 201 (15), 188 (100), 148 (15), 94 (12), 43 (31). 
HR-MS (EI): $m / z$ calcd for $\mathrm{C}_{17} \mathrm{H}_{20} \mathrm{FN}_{3}\left[\mathrm{M}^{+}\right]$285.1641, found 285.1641.

\section{Synthesis of $\mathbf{N}$-(2-Cyclooctyl-6-fluorophenyl)pyrimidin-2-amine (86as)}<smiles>Fc1cccc(C2CCCCCCC2)c1Nc1ncccn1</smiles>

The general procedure D1 was followed using substrate 69a $(189 \mathrm{mg}, 1.0 \mathrm{mmol}$ ) and bromide $80 \mathrm{~s}$ ( $382 \mathrm{mg}, 2.0 \mathrm{mmol})$. Isolation by column chromatography ( $n$-hexane/EtOAc: 9/1) yielded 86 as ( $270 \mathrm{mg}, 90 \%$ ) as a white solid.

M.p.: $111-112^{\circ} \mathrm{C}$.

${ }^{1} \mathrm{H}$ NMR $\left(600 \mathrm{MHz}, \mathrm{CDCl}_{3}\right): \delta=8.33(\mathrm{~d}, J=4.8 \mathrm{~Hz}, 2 \mathrm{H}), 7.22(\mathrm{ddd}, J=8.0,8.0,5.6 \mathrm{~Hz}, 1 \mathrm{H}), 7.09$ (d, $J=7.9 \mathrm{~Hz}, 1 \mathrm{H}$ ), 6.97 (ddd, $J=9.5,8.2,1.3 \mathrm{~Hz}, 1 \mathrm{H}), 6.71(\mathrm{~s}, 1 \mathrm{H}), 6.65(\mathrm{t}, J=4.8 \mathrm{~Hz}, 1 \mathrm{H}$ ), 3.10 $(\mathrm{tt}, J=9.6,3.4 \mathrm{~Hz}, 1 \mathrm{H}), 1.81-1.75(\mathrm{~m}, 2 \mathrm{H}), 1.74-1.67(\mathrm{~m}, 4 \mathrm{H}), 1.62-1.56(\mathrm{~m}, 1 \mathrm{H}), 1.55-1.51$ $(\mathrm{m}, 4 \mathrm{H}), 1.50-1.44(\mathrm{~m}, 3 \mathrm{H})$.

${ }^{13} \mathrm{C}$ NMR $\left(125 \mathrm{MHz}, \mathrm{CDCl}_{3}\right): \delta=162.0\left(\mathrm{C}_{\mathrm{q}}\right), 158.8\left(\mathrm{C}_{\mathrm{q}},{ }^{1} J_{\mathrm{C}-\mathrm{F}}=247.7 \mathrm{~Hz}\right), 158.4(\mathrm{CH}), 150.5\left(\mathrm{C}_{\mathrm{q}}\right)$, $128.1\left(\mathrm{CH},{ }^{3} \mathrm{~J}_{\mathrm{C}-\mathrm{F}}=8.7 \mathrm{~Hz}\right), 123.2\left(\mathrm{C}_{\mathrm{q}},{ }^{2} \mathrm{~J}_{\mathrm{C}-\mathrm{F}}=12.3 \mathrm{~Hz}\right), 122.7\left(\mathrm{CH},{ }^{4} \mathrm{~J}_{\mathrm{C}-\mathrm{F}}=3.5 \mathrm{~Hz}\right), 113.1\left(\mathrm{CH},{ }^{2} \mathrm{~J}_{\mathrm{C}-\mathrm{F}}=\right.$ $20.3 \mathrm{~Hz}), 112.2(\mathrm{CH}), 38.3\left(\mathrm{CH}, \mathrm{d},{ }^{4} J_{\mathrm{C}-\mathrm{F}}=1.9 \mathrm{~Hz}\right), 34.3\left(\mathrm{CH}_{2}\right), 26.8\left(\mathrm{CH}_{2}\right), 26.7\left(\mathrm{CH}_{2}\right), 26.3\left(\mathrm{CH}_{2}\right)$.

${ }^{19}$ F NMR $\left(283 \mathrm{MHz}, \mathrm{CDCl}_{3}\right): \delta=-119.2(\mathrm{ddd}, J=9.4,5.5,1.1 \mathrm{~Hz})$.

IR (neat): $\tilde{v}=3225,2915,2844,1580,1445,1409,1266,785,641 \mathrm{~cm}^{-1}$.

MS (EI): m/z (relative intensity) 299 (63) [M+], 242 (31), 228 (46), 214 (39), 188 (100), 148 (15), 94 (11).

HR-MS (EI): $m / z$ calcd for $\mathrm{C}_{18} \mathrm{H}_{22} \mathrm{FN}_{3}\left[\mathrm{M}^{+}\right]$299.1798, found 299.1798.

Synthesis of $\mathbf{N}$-(2-Cyclododecyl-6-fluorophenyl)pyrimidin-2-amine (86at) 
<smiles>Fc1cccc(C2CCCCCCCCCC2)c1Nc1ncccn1</smiles>

The general procedure D1 was followed using substrate 69a $(189 \mathrm{mg}, 1.0 \mathrm{mmol}$ ) and bromide $80 \mathrm{t}(494 \mathrm{mg}, 2.0 \mathrm{mmol})$. Isolation by column chromatography ( $n$-hexane/EtOAc: $85 / 15$ ) yielded 86 at (330 $\mathrm{mg}, 93 \%$ ) as a white solid.

M.p.: $166-167^{\circ} \mathrm{C}$

${ }^{1} \mathrm{H}$ NMR $\left(600 \mathrm{MHz}, \mathrm{CDCl}_{3}\right): \delta=8.31(\mathrm{~d}, J=4.8 \mathrm{~Hz}, 2 \mathrm{H}), 7.25(\mathrm{ddd}, J=8.0,8.0,5.6 \mathrm{~Hz}, 1 \mathrm{H}), 7.12$ (d, $J=7.9 \mathrm{~Hz}, 1 \mathrm{H}$ ), $7.00(\mathrm{ddd}, J=9.3,8.1,1.0 \mathrm{~Hz}, 1 \mathrm{H}), 6.70(\mathrm{~s}, 1 \mathrm{H}), 6.63(\mathrm{t}, J=4.8 \mathrm{~Hz}, 1 \mathrm{H}), 3.16$ $(\mathrm{tt}, J=6.6,6.6 \mathrm{~Hz}, 1 \mathrm{H}), 1.79-1.71(\mathrm{~m}, 2 \mathrm{H}), 1.48-1.42(\mathrm{~m}, 2 \mathrm{H}), 1.39-1.29(\mathrm{~m}, 6 \mathrm{H}), 1.29-1.16$ $(\mathrm{m}, 10 \mathrm{H}), 1.16-1.07(\mathrm{~m}, 2 \mathrm{H})$.

${ }^{13} \mathrm{C}$ NMR $\left(125 \mathrm{MHz}, \mathrm{CDCl}_{3}\right): \delta=162.1\left(\mathrm{C}_{\mathrm{q}}\right), 159.0\left(\mathrm{C}_{\mathrm{q}},{ }^{1} J_{\mathrm{C}-\mathrm{F}}=247.0 \mathrm{~Hz}\right), 158.4(\mathrm{CH}), 148.4\left(\mathrm{C}_{\mathrm{q}}\right)$, $128.2\left(\mathrm{CH},{ }^{3} \mathrm{~J}_{\mathrm{C}-\mathrm{F}}=8.7 \mathrm{~Hz}\right), 124.5\left(\mathrm{C}_{\mathrm{q}},{ }^{2} \mathrm{~J}_{\mathrm{C}-\mathrm{F}}=12.5 \mathrm{~Hz}\right), 122.9\left(\mathrm{CH},{ }^{4} \mathrm{~J}_{\mathrm{C}-\mathrm{F}}=3.2 \mathrm{~Hz}\right), 113.2\left(\mathrm{CH},{ }^{2} \mathrm{~J}_{\mathrm{C}-\mathrm{F}}=\right.$ $21.3 \mathrm{~Hz}), 112.1(\mathrm{CH}), 33.4\left(\mathrm{CH}, J_{\mathrm{C}-\mathrm{F}}=1.9 \mathrm{~Hz}\right), 31.4\left(\mathrm{CH}_{2}\right), 24.1\left(\mathrm{CH}_{2}\right), 24.0\left(\mathrm{CH}_{2}\right), 23.2\left(\mathrm{CH}_{2}\right)$, $23.0\left(\mathrm{CH}_{2}\right), 22.8\left(\mathrm{CH}_{2}\right)$.

${ }^{19}$ F NMR $\left(283 \mathrm{MHz}, \mathrm{CDCl}_{3}\right): \delta=-119.7(\mathrm{dd}, J=9.5,5.7 \mathrm{~Hz})$.

IR (neat): $\tilde{v}=3218,2930,2844,1595,1450,1415,796,643,511 \mathrm{~cm}^{-1}$.

MS (EI): m/z (relative intensity) 355 (100) $\left[\mathrm{M}^{+}\right], 242$ (21), 228 (35), 214 (40), 201 (39), 188 (98), $148(12), 55$ (21).

HR-MS (EI): $m / z$ calcd for $\mathrm{C}_{22} \mathrm{H}_{30} \mathrm{FN}_{3}\left[\mathrm{M}^{+}\right] 355.2424$, found 355.2419.

Synthesis of $\mathbf{N}$-(2-exo-Norbornyl-6-fluorophenyl)pyrimidin-2-amine (86af)<smiles>Fc1cccc(C2CC3CCC2C3)c1Nc1ncccn1</smiles> 
The general procedure D1 was followed using substrate 69a (189 mg, $1.0 \mathrm{mmol}$ ) and exonorbornyl bromide (80f) $(350 \mathrm{mg}, 2.0 \mathrm{mmol})$. Isolation by column chromatography ( $n$ hexane/EtOAc: $85 / 15$ ) yielded 86 af (260 $\mathrm{mg}, 92 \%$ ) as a white solid.

M.p.: $128-129^{\circ} \mathrm{C}$.

${ }^{1} \mathrm{H}$ NMR $\left(600 \mathrm{MHz}, \mathrm{CDCl}_{3}\right): \delta=8.33(\mathrm{~d}, J=4.8 \mathrm{~Hz}, 2 \mathrm{H}), 7.21(\mathrm{ddd}, J=8.1,8.1,5.6 \mathrm{~Hz}, 1 \mathrm{H}), 7.14$ (d, $J=7.9 \mathrm{~Hz}, 1 \mathrm{H}$ ), 6.99 (ddd, $J=9.5,8.2,1.3 \mathrm{~Hz}, 1 \mathrm{H}), 6.94(\mathrm{~s}, 1 \mathrm{H}), 6.64(\mathrm{t}, J=4.8 \mathrm{~Hz}, 1 \mathrm{H}), 2.92$ (dd, $J=8.9,5.8 \mathrm{~Hz}, 1 \mathrm{H}$ ), 2.41 (d, J=3.0 Hz, 1H), 2.30 (s, 1H), 1.76 (ddd, $J=11.7,9.1,2.2 \mathrm{~Hz}$, $1 \mathrm{H}), 1.59-1.52(\mathrm{~m}, 3 \mathrm{H}), 1.51-1.45(\mathrm{~m}, 1 \mathrm{H}), 1.28-1.18(\mathrm{~m}, 3 \mathrm{H})$.

${ }^{13} \mathrm{C}$ NMR $\left(125 \mathrm{MHz}, \mathrm{CDCl}_{3}\right): \delta=161.7\left(\mathrm{C}_{\mathrm{q}}\right), 159.2\left(\mathrm{C}_{\mathrm{q}},{ }^{1} \mathrm{~J}_{\mathrm{C}-\mathrm{F}}=248.6 \mathrm{~Hz}\right), 158.3(\mathrm{CH}), 147.1\left(\mathrm{C}_{\mathrm{q}}\right)$, $127.6\left(\mathrm{CH},{ }^{3} \mathrm{~J}_{\mathrm{C}-\mathrm{F}}=8.6 \mathrm{~Hz}\right), 124.4\left(\mathrm{C}_{\mathrm{q}},{ }^{2} \mathrm{~J}_{\mathrm{C}-\mathrm{F}}=12.3 \mathrm{~Hz}\right), 121.3\left(\mathrm{CH},{ }^{4} J_{\mathrm{C}-\mathrm{F}}=3.3 \mathrm{~Hz}\right), 113.3\left(\mathrm{CH},{ }^{2} \mathrm{~J}_{\mathrm{C}-\mathrm{F}}=\right.$ $20.7 \mathrm{~Hz}), 112.1(\mathrm{CH}), 42.7\left(\mathrm{CH},{ }^{4} J_{\mathrm{C}-\mathrm{F}}=2.2 \mathrm{~Hz}\right), 41.4\left(\mathrm{CH}_{2}\right), 39.3(\mathrm{CH}), 37.0(\mathrm{CH}), 36.6\left(\mathrm{CH}_{2}\right), 30.5$ $\left(\mathrm{CH}_{2}\right), 28.9\left(\mathrm{CH}_{2}\right)$.

${ }^{19}$ F NMR $\left(283 \mathrm{MHz}, \mathrm{CDCl}_{3}\right): \delta=-118.2(\mathrm{dd}, J=9.4,5.5 \mathrm{~Hz})$.

IR (neat): $\tilde{v}=3217,2950,2867,1582,1524,1410,1262,933,784,641 \mathrm{~cm}^{-1}$.

MS (EI): m/z (relative intensity) 283 (86) $\left[\mathrm{M}^{+}\right], 254$ (84), 214 (37), 201 (45), 188 (100), 148 (20).

HR-MS (EI): $m / z$ calcd for $\mathrm{C}_{17} \mathrm{H}_{18} \mathrm{FN}_{3}\left[\mathrm{M}^{+}\right]$283.1485, found 283.1487.

Synthesis of $\boldsymbol{N}$-(2-Adamantyl-6-fluorophenyl)pyrimidin-2-amine (86ag)<smiles>Fc1cccc(C2C3CC4CC(C3)CC2C4)c1Nc1ncccn1</smiles>

The general procedure D1 was followed using substrate 69a (189 mg, $1.0 \mathrm{mmol}$ ) and bromide $80 \mathrm{~g}(430 \mathrm{mg}, 2.0 \mathrm{mmol})$. Isolation by column chromatography ( $n$-hexane/EtOAc: $85 / 15$ ) yielded $86 \mathrm{ag}(284 \mathrm{mg}, 87 \%$ ) as a yellow solid. 
The general procedure D3 was followed using substrate 69a $(189 \mathrm{mg}, 1.0 \mathrm{mmol})$ and bromide $80 \mathrm{~g}(430 \mathrm{mg}, 2.0 \mathrm{mmol})$. Isolation by column chromatography ( $n$-hexane/EtOAc: $85 / 15)$ yielded $86 \mathrm{ag}(159 \mathrm{mg}, 49 \%)$ as a yellow solid.

M.p.: $169-170{ }^{\circ} \mathrm{C}$

${ }^{1} \mathrm{H}$ NMR $\left(600 \mathrm{MHz}, \mathrm{CDCl}_{3}\right): \delta=8.32(\mathrm{dd}, J=4.8,0.6 \mathrm{~Hz}, 2 \mathrm{H}), 7.43(\mathrm{~d}, J=8.0 \mathrm{~Hz}, 1 \mathrm{H}$ ), 7.24 (ddd, $J=8.0,8.0,5.4 \mathrm{~Hz}, 1 \mathrm{H}), 7.03(\mathrm{dd}, J=8.0,8.0 \mathrm{~Hz}, 1 \mathrm{H}), 6.84(\mathrm{~s}, 1 \mathrm{H}), 6.64(\mathrm{td}, J=4.8,0.6 \mathrm{~Hz}, 1 \mathrm{H})$, $3.27(\mathrm{~s}, 1 \mathrm{H}), 2.23(\mathrm{~s}, 2 \mathrm{H}), 2.07-2.02(\mathrm{~m}, 2 \mathrm{H}), 1.93-1.81(\mathrm{~m}, 6 \mathrm{H}), 1.75(\mathrm{~s}, 2 \mathrm{H}), 1.63(\mathrm{~d}, J=$ $12.2 \mathrm{~Hz}, 2 \mathrm{H})$.

${ }^{13} \mathrm{C}$ NMR $\left(125 \mathrm{MHz}, \mathrm{CDCl}_{3}\right): \delta=161.6\left(\mathrm{C}_{\mathrm{q}}\right), 159.2\left(\mathrm{C}_{\mathrm{q}},{ }^{1} J_{\mathrm{C}-\mathrm{F}}=247.9 \mathrm{~Hz}\right), 158.3(\mathrm{CH}), 145.3\left(\mathrm{C}_{\mathrm{q}}\right)$, $127.3\left(\mathrm{CH}, \mathrm{d},{ }^{3} J_{\mathrm{C}-\mathrm{F}}=8.7 \mathrm{~Hz}\right), 125.0\left(\mathrm{C}_{\mathrm{q}},{ }^{2} \mathrm{~J}_{\mathrm{C}-\mathrm{F}}=12.2 \mathrm{~Hz}\right), 123.3\left(\mathrm{CH},{ }^{4} J_{\mathrm{C}-\mathrm{F}}=3.2 \mathrm{~Hz}\right), 113.6\left(\mathrm{CH},{ }^{2} \mathrm{~J}_{\mathrm{C}-\mathrm{F}}\right.$ $=20.3 \mathrm{~Hz}), 112.1(\mathrm{CH}), 45.6\left(\mathrm{CH},{ }^{4} J_{C-F}=2.0 \mathrm{~Hz}\right), 40.3(\mathrm{CH}), 38.0\left(\mathrm{CH}_{2}\right), 32.8(\mathrm{CH}), 32.0(\mathrm{CH})$, $28.1\left(\mathrm{CH}_{2}\right), 27.7\left(\mathrm{CH}_{2}\right)$.

${ }^{19}$ F NMR $\left(283 \mathrm{MHz}, \mathrm{CDCl}_{3}\right): \delta=-118.3(\mathrm{dd}, J=9.4,5.6 \mathrm{~Hz})$.

IR (neat): $\tilde{v}=3210,2897,2849,1584,1445,1411,995,789,641,492 \mathrm{~cm}^{-1}$.

MS (EI): m/z (relative intensity) $323(66)\left[\mathrm{M}^{+}\right], 295$ (100), 266 (10), 201 (16), 188 (76), 170 (9).

HR-MS (EI): $m / z$ calcd for $\mathrm{C}_{20} \mathrm{H}_{22} \mathrm{FN}_{3}\left[\mathrm{M}^{+}\right] 323.1798$, found 323.1808 .

Synthesis of $\mathbf{N}$-(2-Fluoro-6-isopropylphenyl)pyrimidin-2-amine (86ai)<smiles>CC(C)c1cccc(F)c1Nc1ncccn1</smiles>

The general procedure D1 was followed using substrate 69a (189 mg, $1.0 \mathrm{mmol}$ ) and bromide $80 \mathrm{i}$ ( $246 \mathrm{mg}, 2.0 \mathrm{mmol}$ ). Isolation by column chromatography ( $n$-hexane/EtOAc: $85 / 15$ ) yielded 86 ai ( $219 \mathrm{mg}, 95 \%$ ) as a white solid.

M.p.: $131-132{ }^{\circ} \mathrm{C}$ 
${ }^{1} \mathbf{H}$ NMR $\left(600 \mathrm{MHz}, \mathrm{CDCl}_{3}\right): \delta=8.32(\mathrm{~d}, J=4.8 \mathrm{~Hz}, 2 \mathrm{H}), 7.26(\mathrm{ddd}, J=8.1,8.1,5.6 \mathrm{~Hz}, 1 \mathrm{H})$, 7.17-7.12 (m, 2H), 7.00 (ddd, $J=9.5,8.2,1.3 \mathrm{~Hz}, 1 \mathrm{H}$ ), $6.64(\mathrm{t}, J=4.8 \mathrm{~Hz}, 1 \mathrm{H}$ ), 3.26 (hept, $J=$ $6.9 \mathrm{~Hz}, 1 \mathrm{H}), 1.21(\mathrm{~d}, J=6.9 \mathrm{~Hz}, 6 \mathrm{H})$.

${ }^{13} \mathrm{C} \mathrm{NMR}\left(125 \mathrm{MHz}, \mathrm{CDCl}_{3}\right): \delta=162.1\left(\mathrm{C}_{\mathrm{q}}\right), 158.9\left(\mathrm{C}_{\mathrm{q}},{ }^{1} J_{\mathrm{C}-\mathrm{F}}=247.5 \mathrm{~Hz}\right), 158.4(\mathrm{CH}), 148.8\left(\mathrm{C}_{\mathrm{q}}\right)$, $128.1\left(\mathrm{CH},{ }^{3} \mathrm{~J}_{\mathrm{C}-\mathrm{F}}=8.5 \mathrm{~Hz}\right), 123.8\left(\mathrm{C}_{\mathrm{q}},{ }^{2} \mathrm{~J}_{\mathrm{C}-\mathrm{F}}=12.7 \mathrm{~Hz}\right), 121.4\left(\mathrm{CH},{ }^{4} J_{\mathrm{C}-\mathrm{F}}=3.4 \mathrm{~Hz}\right), 113.4\left(\mathrm{CH},{ }^{2} \mathrm{~J}_{\mathrm{C}-\mathrm{F}}=\right.$ $20.8 \mathrm{~Hz}), 112.2(\mathrm{CH}), 28.6\left(\mathrm{CH},{ }^{4} J_{\mathrm{C}-\mathrm{F}}=2.3 \mathrm{~Hz}\right), 23.4\left(\mathrm{CH}_{3}\right)$.

${ }^{19}$ F NMR $\left(283 \mathrm{MHz}, \mathrm{CDCl}_{3}\right): \delta=-119.3(\mathrm{dd}, J=9.6,5.4 \mathrm{~Hz})$.

IR (neat): $\tilde{v}=3217,2969,2928,1575,1445,1410,1245,954,787,638 \mathrm{~cm}^{-1}$.

MS (EI): m/z (relative intensity) 231 (43) [M+], 215 (22), 196 (10), 188 (100), 170 (6).

HR-MS (EI): $m / z$ calcd for $\mathrm{C}_{13} \mathrm{H}_{14} \mathrm{FN}_{3}\left[\mathrm{M}^{+}\right]$231.1172, found 231.1171.

\section{Synthesis of $N$-[2-Fluoro-6-(pentan-2-yl)phenyl]pyrimidin-2-amine (86am)}<smiles>CC(C)C(c1cccc(F)c1Nc1ncccn1)C(C)C</smiles>

The general procedure D1 was followed using substrate 69a $(189 \mathrm{mg}, 1.0 \mathrm{mmol}$ ) and bromide $80 \mathrm{~m}$ ( $302 \mathrm{mg}, 2.0 \mathrm{mmol}$ ). Isolation by column chromatography ( $n$-hexane/EtOAc: $85 / 15$ ) yielded $86 \mathrm{am}$ ( $245 \mathrm{mg}, 94 \%$ ) as a white solid.

M.p.: $122-123^{\circ} \mathrm{C}$

${ }^{1} \mathrm{H}$ NMR $\left(600 \mathrm{MHz}, \mathrm{CDCl}_{3}\right): \delta=8.32(\mathrm{~d}, J=4.8 \mathrm{~Hz}, 2 \mathrm{H}), 7.25(\mathrm{ddd}, J=8.0,8.0,5.4 \mathrm{~Hz}, 1 \mathrm{H}), 7.10$ (d, $J=7.9 \mathrm{~Hz}, 1 \mathrm{H}), 6.99$ (ddd, $J=9.5,8.2,1.4 \mathrm{~Hz}, 1 \mathrm{H}), 6.97(\mathrm{~s}, 1 \mathrm{H}), 6.64(\mathrm{t}, J=4.8 \mathrm{~Hz}, 1 \mathrm{H}), 3.09$ (qt, $J=7.1,7.1 \mathrm{~Hz}, 1 \mathrm{H}), 1.59-1.54(\mathrm{~m}, 1 \mathrm{H}), 1.53-1.46(\mathrm{~m}, 1 \mathrm{H}), 1.27-1.20(\mathrm{~m}, 1 \mathrm{H}), 1.19(\mathrm{~d}, J=$ $7.1 \mathrm{~Hz}, 3 \mathrm{H}), 1.17-1.10(\mathrm{~m}, 1 \mathrm{H}), 0.79(\mathrm{t}, J=7.4 \mathrm{~Hz}, 3 \mathrm{H})$.

${ }^{13} \mathrm{C}$ NMR $\left(125 \mathrm{MHz}, \mathrm{CDCl}_{3}\right): \delta=162.0\left(\mathrm{C}_{\mathrm{q}}\right), 158.9\left(\mathrm{C}_{\mathrm{q}},{ }^{1} J_{\mathrm{C}-\mathrm{F}}=247.3 \mathrm{~Hz}\right), 158.3(\mathrm{CH}), 148.2\left(\mathrm{C}_{\mathrm{q}}\right)$, $128.1\left(\mathrm{CH},{ }^{3} J_{\mathrm{C}-\mathrm{F}}=8.4 \mathrm{~Hz}\right), 124.2\left(\mathrm{C}_{\mathrm{q}},{ }^{2} \mathrm{~J}_{\mathrm{C}-\mathrm{F}}=12.7 \mathrm{~Hz}\right), 121.9\left(\mathrm{CH},{ }^{4} \mathrm{~J}_{\mathrm{C}-\mathrm{F}}=3.5 \mathrm{~Hz}\right), 113.3\left(\mathrm{CH},{ }^{2} \mathrm{~J}_{\mathrm{C}-\mathrm{F}}\right.$ $=20.8 \mathrm{~Hz}), 112.2(\mathrm{CH}), 40.3\left(\mathrm{CH}_{2}\right), 33.5\left(\mathrm{CH},{ }^{4} \mathrm{~J}_{\mathrm{C}-\mathrm{F}}=2.1 \mathrm{~Hz}\right), 21.6\left(\mathrm{CH}_{3}\right), 20.9\left(\mathrm{CH}_{2}\right), 14.2\left(\mathrm{CH}_{3}\right)$.

${ }^{19}$ F NMR $\left(283 \mathrm{MHz}, \mathrm{CDCl}_{3}\right): \delta=-119.2(\mathrm{dd}, J=9.4,5.5 \mathrm{~Hz})$

IR (neat): $\tilde{v}=3211,2963,2864,1582,1527,1446,1267,957,786,641 \mathrm{~cm}^{-1}$. 
MS (EI): m/z (relative intensity) 259 (22) [M+], 240 (8), 230 (100), 217 (13), 202 (15), 188 (40).

HR-MS (EI): $m / z$ calcd for $\mathrm{C}_{15} \mathrm{H}_{18} \mathrm{FN}_{3}\left[\mathrm{M}^{+}\right] 259.1485$, found 259.1480 .

\section{Synthesis of $\mathbf{N}$-[2-Fluoro-6-(octan-2-yl)phenyl]pyrimidin-2-amine (86as)}<smiles>CC(O)C(C)c1cccc(F)c1Nc1ncccn1</smiles>

The general procedure D1 was followed using substrate 69a $(189 \mathrm{mg}, 1.0 \mathrm{mmol}$ ) and bromide $80 \mathrm{~s}$ ( $386 \mathrm{mg}, 2.0 \mathrm{mmol}$ ). Isolation by column chromatography ( $n$-hexane/EtOAc: $85 / 15$ ) yielded $86 a$ ( $284 \mathrm{mg}, 94 \%$ ) as a white solid.

M.p.: $85-86^{\circ} \mathrm{C}$

${ }^{1} \mathrm{H}$ NMR $\left(600 \mathrm{MHz}, \mathrm{CDCl}_{3}\right) \delta=8.31(\mathrm{~d}, J=4.8 \mathrm{~Hz}, 2 \mathrm{H}), 7.27-7.23(\mathrm{~m}, 2 \mathrm{H}), 7.10(\mathrm{~d}, J=7.9 \mathrm{~Hz}$, $1 \mathrm{H}$ ), 7.00 (ddd, $J=9.5,8.2,1.3 \mathrm{~Hz}, 1 \mathrm{H}), 6.63(\mathrm{t}, J=4.8 \mathrm{~Hz}, 1 \mathrm{H}), 3.08(\mathrm{qt}, J=7.0,7.0 \mathrm{~Hz}, 1 \mathrm{H}$ ), 1.61-1.53 (m, 1H), 1.54-1.46 (m, 1H), $1.19(\mathrm{~d}, J=6.9 \mathrm{~Hz}, 3 \mathrm{H}), 1.21-1.07(\mathrm{~m}, 8 \mathrm{H}), 0.82(\mathrm{t}, J=$ $7.1 \mathrm{~Hz}, 3 \mathrm{H})$.

${ }^{13} \mathrm{C}$ NMR $\left(125 \mathrm{MHz}, \mathrm{CDCl}_{3}\right) \delta=162.1\left(\mathrm{C}_{\mathrm{q}}\right), 158.9\left(\mathrm{C}_{\mathrm{q}},{ }^{1} \mathrm{~J}_{\mathrm{C}-\mathrm{F}}=247.7 \mathrm{~Hz}\right), 158.3(\mathrm{CH}), 148.2\left(\mathrm{C}_{\mathrm{q}}\right)$, $128.1\left(\mathrm{CH},{ }^{3} J_{\mathrm{C}-\mathrm{F}}=8.7 \mathrm{~Hz}\right), 124.3\left(\mathrm{C}_{\mathrm{q}},{ }^{2} \mathrm{~J}_{\mathrm{C}-\mathrm{F}}=12.8 \mathrm{~Hz}\right), 121.9\left(\mathrm{CH},{ }^{4} J_{\mathrm{C}-\mathrm{F}}=3.4 \mathrm{~Hz}\right), 113.2\left(\mathrm{CH},{ }^{2} \mathrm{~J}_{\mathrm{C}-\mathrm{F}}=\right.$ $21.0 \mathrm{~Hz}), 112.1(\mathrm{CH}), 38.1\left(\mathrm{CH}_{2}\right), 33.8\left(\mathrm{CH},{ }^{4} J_{\mathrm{C}-\mathrm{F}}=2.3 \mathrm{~Hz}\right), 31.8\left(\mathrm{CH}_{2}\right), 29.5\left(\mathrm{CH}_{2}\right), 27.7\left(\mathrm{CH}_{2}\right)$, $22.7\left(\mathrm{CH}_{2}\right), 21.7\left(\mathrm{CH}_{3}\right), 14.2\left(\mathrm{CH}_{3}\right)$.

${ }^{19}$ F NMR $\left(283 \mathrm{MHz}, \mathrm{CDCl}_{3}\right) \delta=-119.1(\mathrm{dd}, J=9.4,5.4 \mathrm{~Hz})$.

IR (neat): $\tilde{v}=3202,2921,2855,1580,1518,1448,1414,943,787,640 \mathrm{~cm}^{-1}$.

MS (EI): m/z (relative intensity) $301(65)\left[\mathrm{M}^{+}\right], 230$ (100), 217 (40), 202 (41), 188 (93), 146 (15).

HR-MS (EI): $m / z$ calcd for $\mathrm{C}_{15} \mathrm{H}_{18} \mathrm{FN}_{3}\left[\mathrm{M}^{+}\right]$301.1954, found 301.1960. 
<smiles>CCCCC(CCCC)C(CCCC)c1cccc(F)c1Nc1ncccn1</smiles>

The general procedure D1 was followed using substrate 69a $(189 \mathrm{mg}, 1.0 \mathrm{mmol}$ ) and bromide $80 \mathrm{t}(414 \mathrm{mg}, 2.0 \mathrm{mmol})$. Isolation by column chromatography ( $n$-hexane/EtOAc: $8 / 2$ ) yielded 86 at $(270 \mathrm{mg}, 85 \%)$ as a yellow solid.

M.p.: $77-78^{\circ} \mathrm{C}$

${ }^{1} \mathrm{H}$ NMR $\left(600 \mathrm{MHz}, \mathrm{CDCl}_{3}\right): \delta=8.30(\mathrm{~d}, J=4.8 \mathrm{~Hz}, 2 \mathrm{H}), 7.24(\mathrm{dd}, J=8.1,5.5 \mathrm{~Hz}, 1 \mathrm{H}), 7.05(\mathrm{~d}, J$ $=7.9 \mathrm{~Hz}, 1 \mathrm{H}), 6.99(\mathrm{dd}, J=7.5,9.2 \mathrm{~Hz}, 1 \mathrm{H}), 6.81(\mathrm{br} \mathrm{s}, 1 \mathrm{H}), 6.62(\mathrm{t}, J=4.8 \mathrm{~Hz}, 1 \mathrm{H}), 2.96(\mathrm{tt}, J=$ 8.6, $5.9 \mathrm{~Hz}, 1 \mathrm{H}), 1.65-1.57(\mathrm{~m}, 2 \mathrm{H}), 1.57-1.50(\mathrm{~m}, 2 \mathrm{H}), 1.24-1.02(\mathrm{~m}, 8 \mathrm{H}), 0.77(\mathrm{t}, J=7.2 \mathrm{~Hz}$, $6 \mathrm{H})$.

${ }^{13} \mathrm{C}$ NMR $\left(125 \mathrm{MHz}, \mathrm{CDCl}_{3}\right): \delta=161.8\left(\mathrm{C}_{\mathrm{q}}\right), 158.9\left(\mathrm{C}_{\mathrm{q}},{ }^{1} J_{\mathrm{C}-\mathrm{F}}=248.7 \mathrm{~Hz}\right), 158.1(\mathrm{CH}), 146.8\left(\mathrm{C}_{\mathrm{q}}\right)$, $127.9\left(\mathrm{CH},{ }^{3} \mathrm{~J}_{\mathrm{C}-\mathrm{F}}=8.2 \mathrm{~Hz}\right), 124.8\left(\mathrm{C}_{\mathrm{q}},{ }^{2} \mathrm{~J}_{\mathrm{C}-\mathrm{F}}=12.7 \mathrm{~Hz}\right), 122.1\left(\mathrm{CH},{ }^{4} \mathrm{~J}_{\mathrm{C}-\mathrm{F}}=3.9 \mathrm{~Hz}\right), 113.0\left(\mathrm{CH},{ }^{2} \mathrm{~J}_{\mathrm{C}-\mathrm{F}}=\right.$ $21.4 \mathrm{~Hz}), 111.8(\mathrm{CH}), 39.3(\mathrm{CH}), 36.2\left(\mathrm{CH}_{2}\right), 29.8\left(\mathrm{CH}_{2}\right), 22.8\left(\mathrm{CH}_{2}\right), 13.9\left(\mathrm{CH}_{3}\right)$.

${ }^{19}$ F NMR $\left(283 \mathrm{MHz}, \mathrm{CDCl}_{3}\right): \delta=-118.5(\mathrm{dd}, J=9.57,5.59 \mathrm{~Hz})$.

IR (neat): $\tilde{v}=3211,2951,2921,1591,1521,1413,1258,912,797,617 \mathrm{~cm}^{-1}$.

MS (EI): $m / z$ (relative intensity) $315(53)\left[\mathrm{M}^{+}\right], 272$ (100), 259 (31), 244 (40), 216 (24), 202 (31), 188 (53).

HR-MS (EI): $\mathrm{m} / \mathrm{z}$ calcd for $\mathrm{C}_{19} \mathrm{H}_{26} \mathrm{FN}_{3}\left[\mathrm{M}^{+}\right]$315.2111, found 315.2117.

\section{Synthesis of tert-Butyl-5-[3-fluoro-2-(pyrimidin-2-ylamino)phenyl]hexanoate (86au')}<smiles>CCCCC(=O)OCCCC(C)c1cccc(F)c1Nc1ncccn1</smiles>

The general procedure D1 was followed using 69a (189 mg, $1.00 \mathrm{mmol}$ ) and 80u (418 mg, $2.0 \mathrm{mmol}$ ). After purification by column chromatography ( $n$-hexane/EtOAc 90:10) side product 86au' (24 mg, 7\%) was obtained as a white solid. 
86au':

M.p.: $118-119^{\circ} \mathrm{C}$

${ }^{1} \mathbf{H}$ NMR $\left(600 \mathrm{MHz}, \mathrm{CDCl}_{3}\right): \delta=8.33(\mathrm{~d}, J=4.8 \mathrm{~Hz}, 2 \mathrm{H}), 7.28-7.23(\mathrm{~m}, 1 \mathrm{H}), 7.09(\mathrm{~d}, J=7.9 \mathrm{~Hz}$, $1 \mathrm{H}), 6.99$ (ddd, $J=9.5,8.2,1.3 \mathrm{~Hz}, 1 \mathrm{H}), 6.66(\mathrm{t}, J=4.8 \mathrm{~Hz}, 1 \mathrm{H}), 6.54(\mathrm{~s}, 1 \mathrm{H}), 3.08(\mathrm{tq}, J=6.9$, $6.9 \mathrm{~Hz}, 1 \mathrm{H}), 2.12(\mathrm{t}, J=7.3 \mathrm{~Hz}, 2 \mathrm{H}), 1.65-1.47(\mathrm{~m}, 3 \mathrm{H}), 1.45-1.42(\mathrm{~m}, 1 \mathrm{H}), 1.41(\mathrm{~s}, 9 \mathrm{H}), 1.20$ $(\mathrm{d}, J=6.9 \mathrm{~Hz}, 3 \mathrm{H})$.

${ }^{13} \mathrm{C}$ NMR (125 MHz, CDCl $): \delta=172.9(\mathrm{Cq}), 161.9(\mathrm{Cq}), 158.8\left(\mathrm{C}_{\mathrm{q}}, \mathrm{d},{ }^{1} \mathrm{~J}_{\mathrm{C}-\mathrm{F}}=247.0 \mathrm{~Hz}\right), 158.3$ $(\mathrm{CH}), 147.6\left(\mathrm{C}_{\mathrm{q}}\right), 128.2\left(\mathrm{CH}, \mathrm{d},{ }^{3} J_{\mathrm{C}-\mathrm{F}}=8.6 \mathrm{~Hz}\right), 124.2\left(\mathrm{C}_{\mathrm{q}}, \mathrm{d},{ }^{2} \mathrm{~J}_{\mathrm{C}-\mathrm{F}}=13.2 \mathrm{~Hz}\right), 121.8\left(\mathrm{CH}, \mathrm{d},{ }^{4} \mathrm{~J}_{\mathrm{C}-\mathrm{F}}=\right.$ $3.5 \mathrm{~Hz}), 113.4\left(\mathrm{CH}, \mathrm{d},{ }^{2} J_{\mathrm{C}-\mathrm{F}}=20.6 \mathrm{~Hz}\right), 112.3(\mathrm{CH}), 80.2\left(\mathrm{C}_{\mathrm{q}}\right), 37.3\left(\mathrm{CH}_{2}\right), 35.7\left(\mathrm{CH}_{2}\right), 33.7(\mathrm{CH}, \mathrm{d}$, $\left.{ }^{4} J_{C-F}=2.1 \mathrm{~Hz}\right), 28.3\left(\mathrm{CH}_{3}\right), 23.4\left(\mathrm{CH}_{2}\right), 21.8\left(\mathrm{CH}_{3}\right)$.

${ }^{19}$ F NMR $\left(283 \mathrm{MHz}, \mathrm{CDCl}_{3}\right): \delta=-119.12(\mathrm{dd}, J=9.5,5.7 \mathrm{~Hz})$

IR (neat): $\tilde{v}=3198,2977,2927,2865,1719,1581,1446,1392,1154,787 \mathrm{~cm}^{-1}$.

MS (EI): m/z (relative intensity) 359 (19) $\left[\mathrm{M}^{+}\right], 303$ (12), 286 (25), 230 (33), 217 (23), 188 (100).

HR-MS (ESI): $\mathrm{m} / \mathrm{z}$ calcd for $\mathrm{C}_{20} \mathrm{H}_{27} \mathrm{FN}_{3} \mathrm{O}_{2}\left[\mathrm{M}+\mathrm{H}^{+}\right]$360.2087, found 360.2084.

\section{Synthesis of 2-\{4-[3-fluoro-2-(pyrimidin-2-ylamino)phenyl]pentyl\}isoindoline-1,3-dione} (86ap)<smiles>CC(CCCN1C(=O)c2ccccc2C1=O)c1cccc(F)c1Nc1ncccn1</smiles>

The general procedure D1 was followed using 69a (189 mg, $1.0 \mathrm{mmol})$ and $80 \mathrm{p}(592 \mathrm{mg}$, $2.0 \mathrm{mmol}$ ). After purification by column chromatography ( $n$-hexane/EtOAc 2:1) 86ap (324 mg, 80\%) was obtained as a white solid.

M.p.: $61-62^{\circ} \mathrm{C}$

${ }^{1} \mathrm{H}$ NMR $\left(600 \mathrm{MHz}, \mathrm{CDCl}_{3}\right): \delta=8.29(\mathrm{~d}, J=4.8 \mathrm{~Hz}, 2 \mathrm{H}), 7.80(\mathrm{dd}, J=5.5,3.1 \mathrm{~Hz}, 2 \mathrm{H}), 7.67(\mathrm{dd}, J$ $=5.5,3.1 \mathrm{~Hz}, 2 \mathrm{H}), 7.23(\mathrm{td}, J=8.0,5.6 \mathrm{~Hz}, 1 \mathrm{H}), 7.12(\mathrm{~s}, 1 \mathrm{H}), 7.07(\mathrm{~d}, J=7.9 \mathrm{~Hz}, 1 \mathrm{H}), 6.97$ (dd, J $=8.9,8.7 \mathrm{~Hz}, 1 \mathrm{H}), 6.61(\mathrm{t}, J=4.8 \mathrm{~Hz}, 1 \mathrm{H}), 3.64(\mathrm{dt}, J=14.3,7.3 \mathrm{~Hz}, 1 \mathrm{H}), 3.56(\mathrm{dt}, J=14.3$, $7.3 \mathrm{~Hz}, 1 \mathrm{H}), 3.17(\mathrm{tq}, J=6.9,6.7 \mathrm{~Hz}, 1 \mathrm{H}), 1.67-1.51(\mathrm{~m}, 4 \mathrm{H}), 1.20(\mathrm{~d}, J=6.9 \mathrm{~Hz}, 3 \mathrm{H})$. 
${ }^{13} \mathrm{C}$ NMR $\left(125 \mathrm{MHz}, \mathrm{CDCl}_{3}\right): \delta=168.4\left(\mathrm{C}_{\mathrm{q}}\right), 162.0\left(\mathrm{C}_{\mathrm{q}}\right), 158.8\left(\mathrm{C}_{\mathrm{q}}, \mathrm{d},{ }^{1} \mathrm{~J}_{\mathrm{C}-\mathrm{F}}=247.3 \mathrm{~Hz}\right), 158.2$ $(\mathrm{CH}), 147.5\left(\mathrm{C}_{\mathrm{q}}\right), 133.9(\mathrm{CH}), 132.1\left(\mathrm{C}_{\mathrm{q}}\right), 128.2\left(\mathrm{CH}, \mathrm{d},{ }^{3} J_{\mathrm{C}-\mathrm{F}}=9.1 \mathrm{~Hz}\right), 124.5\left(\mathrm{C}_{q}, \mathrm{~d},{ }^{2} \mathrm{~J}_{\mathrm{C}-\mathrm{F}}=\right.$ $11.2 \mathrm{~Hz}), 123.2(\mathrm{CH}), 121.8\left(\mathrm{CH}, \mathrm{d},{ }^{4} J_{\mathrm{C}-\mathrm{F}}=3.4 \mathrm{~Hz}\right), 113.4\left(\mathrm{CH}, \mathrm{d},{ }^{2} J_{\mathrm{C}-\mathrm{F}}=21.5 \mathrm{~Hz}\right), 112.1(\mathrm{CH})$, $37.9\left(\mathrm{CH}_{2}\right), 34.9\left(\mathrm{CH}_{2}\right), 32.9\left(\mathrm{CH}, \mathrm{d},{ }^{4} J_{\mathrm{C}-\mathrm{F}}=1.4 \mathrm{~Hz}\right), 26.7\left(\mathrm{CH}_{2}\right), 21.9\left(\mathrm{CH}_{3}\right)$.

${ }^{19}$ F NMR $\left(283 \mathrm{MHz}, \mathrm{CDCl}_{3}\right): \delta=-119.16(\mathrm{dd}, J=9.4,5.6 \mathrm{~Hz})$.

IR (neat): $\tilde{v}=3342,3216,2960,2931,1704,1581,1444,1394,788,717 \mathrm{~cm}^{-1}$.

MS (EI): $m / z$ (relative intensity) $404(25)\left[\mathrm{M}^{+}\right], 244$ (12), 230 (42), 217 (18), 188 (100), 160 (20).

HR-MS (EI): $\mathrm{m} / \mathrm{z}$ calcd for $\mathrm{C}_{23} \mathrm{H}_{21} \mathrm{FN}_{4} \mathrm{O}_{2}\left[\mathrm{M}^{+}\right]$404.1649, found 404.1647 .

\section{Synthesis of $N$-(2-Fluorophenyl)-N-(1-phenylethyl)pyrimidin-2-amine (86av")}<smiles>CC(c1ccccc1)N(c1ccccn1)c1ccccc1F</smiles>

The general procedure D1 was followed using substrate 69a (189 mg, $1.0 \mathrm{mmol}$ ) and bromide $80 \mathrm{v}$ ( $370 \mathrm{mg}, 2.0 \mathrm{mmol}$ ). Isolation by column chromatography ( $n$-hexane/EtOAc: $95 / 5$ ) yielded 86av" (246 mg, 84\%) as a white solid.

M.p.: $96-97^{\circ} \mathrm{C}$.

${ }^{1} \mathrm{H}$ NMR $\left(600 \mathrm{MHz}, \mathrm{CDCl}_{3}\right): \delta=8.33(\mathrm{~d}, J=4.7 \mathrm{~Hz}, 2 \mathrm{H}), 7.29(\mathrm{~d}, J=7.0 \mathrm{~Hz}, 1 \mathrm{H}), 7.27-7.19(\mathrm{~m}$, $5 \mathrm{H}), 7.06(\mathrm{t}, J=8.8 \mathrm{~Hz}, 1 \mathrm{H}), 6.97(\mathrm{dd}, J=6.8,6.8 \mathrm{~Hz}, 1 \mathrm{H}), 6.68(\mathrm{bs}, 1 \mathrm{H}), 6.57(\mathrm{t}, J=4.7 \mathrm{~Hz}, 1 \mathrm{H})$, $6.48(q, J=6.5 \mathrm{~Hz}, 1 \mathrm{H}), 1.53(\mathrm{~d}, J=6.5 \mathrm{~Hz}, 3 \mathrm{H})$.

${ }^{13} \mathrm{C} \mathrm{NMR}\left(126 \mathrm{MHz}, \mathrm{CDCl}_{3}\right): \delta=161.7\left(\mathrm{C}_{\mathrm{q}}\right), 160.0\left(\mathrm{C}_{\mathrm{q}}, \mathrm{d}^{1}{ }^{1} \mathrm{~J}_{\mathrm{C}-\mathrm{F}}=247.9 \mathrm{~Hz}\right), 157.8(\mathrm{CH}), 142.2\left(\mathrm{C}_{\mathrm{q}}\right)$ $131.8\left(\mathrm{CH}^{4}{ }^{4} \mathrm{~J}_{\mathrm{C}-\mathrm{F}}=1.6 \mathrm{~Hz}\right), 128.8\left(\mathrm{CH}, \mathrm{d},{ }^{3} J_{\mathrm{C}-F}=7.5 \mathrm{~Hz}\right), 128.1(\mathrm{CH}), 128.0\left(\mathrm{C}_{\mathrm{q}}\right), 127.8(\mathrm{CH}), 127.2$ $(\mathrm{CH}), 124.0\left(\mathrm{CH}, \mathrm{d},{ }^{3} J_{C-F}=4.9 \mathrm{~Hz}\right), 116.0\left(\mathrm{CH}, \mathrm{d},{ }^{2} J_{C-F}=23.5 \mathrm{~Hz}\right), 111.1(\mathrm{CH}), 54.2(\mathrm{CH}), 17.0$ $\left(\mathrm{CH}_{3}\right)$.

${ }^{19} \mathrm{~F}$ NMR $\left(283 \mathrm{MHz}, \mathrm{CDCl}_{3}\right): \delta=-117.2(\mathrm{bs})$.

IR (neat): $\tilde{v}=3088,2982,2936,1578,1495,1433,1067,798,750,593 \mathrm{~cm}^{-1}$.

MS (EI) m/z (relative intensity) 293 (43) [M+], 214 (9), 189 (28), 170 (100), 136 (4), 105 (45).

HR-MS (EI) $\mathrm{m} / \mathrm{z}$ calcd for $\mathrm{C}_{18} \mathrm{H}_{16} \mathrm{FN}_{3}\left[\mathrm{M}^{+}\right]$293.1328, found 293.1332 . 
Synthesis of $\mathrm{N}$-Benzhydryl-N-(2-fluorophenyl)pyrimidin-2-amine (86ao")<smiles>Fc1ccccc1N(c1ncccn1)C(c1ccccc1)c1ccccc1</smiles>

The general procedure D1 was followed using substrate 69 (189 mg, $1.0 \mathrm{mmol}$ ) and bromide 800 (494 mg, $2.0 \mathrm{mmol}$ ). Isolation by column chromatography ( $n$-hexane/EtOAc: $9 / 1$ ) yielded 86ao" (275 mg, 77\%) as a yellow solid.

M.p.: $180-181^{\circ} \mathrm{C}$.

${ }^{1} \mathbf{H}$ NMR $\left(300 \mathrm{MHz}, \mathrm{CDCl}_{3}\right): \delta=8.33(\mathrm{~d}, J=4.8 \mathrm{~Hz}, 2 \mathrm{H}), 7.40(\mathrm{~s}, 1 \mathrm{H}), 7.39-7.29(\mathrm{~m}, 1 \mathrm{H}), 7.26-$ $7.15(\mathrm{~m}, 10 \mathrm{H}), 7.14-7.03(\mathrm{~m}, 1 \mathrm{H}), 6.93$ (ddd, $J=7.7,7.7,1.4 \mathrm{~Hz}, 1 \mathrm{H}), 6.82(\mathrm{dd}, J=9.9,8.1 \mathrm{~Hz}$, $1 \mathrm{H}), 6.61(\mathrm{t}, J=4.8 \mathrm{~Hz}, 1 \mathrm{H})$.

${ }^{13} \mathrm{C} \mathrm{NMR}\left(126 \mathrm{MHz}, \mathrm{CDCl}_{3}\right): \delta=161.8\left(\mathrm{C}_{\mathrm{q}}\right), 159.4\left(\mathrm{C}_{\mathrm{q}}, \mathrm{d}, J_{\mathrm{C}-\mathrm{F}}=247.7 \mathrm{~Hz}\right), 157.8(\mathrm{CH}), 140.8\left(\mathrm{C}_{\mathrm{q}}\right)$, $130.8\left(\mathrm{CH}, \mathrm{d}, J_{C-F}=1.5 \mathrm{~Hz}\right), 129.6\left(\mathrm{C}_{\mathrm{q}}, \mathrm{d}, J_{C-F}=12.6 \mathrm{~Hz}\right), 129.4(\mathrm{CH}), 128.5\left(\mathrm{CH}, \mathrm{d}, J_{C-F}=7.2 \mathrm{~Hz}\right)$, $128.5(\mathrm{CH}), 127.8(\mathrm{CH}), 127.5\left(\mathrm{C}_{\mathrm{q}}\right), 127.0(\mathrm{CH}), 126.5(\mathrm{CH}), 123.9(\mathrm{CH}), 111.6(\mathrm{CH}), 66.5(\mathrm{CH})$.

${ }^{19}$ F NMR $\left(283 \mathrm{MHz}^{\mathrm{C}} \mathrm{CDCl}_{3}\right): \delta=-116.0(\mathrm{ddd}, J=10.2,7.6,5.0 \mathrm{~Hz})$.

IR (neat): $\tilde{v}=3290,3056,2922,1582,1523,1430,1292,1201,1025,736 \mathrm{~cm}^{-1}$.

MS (EI) m/z (relative intensity) 355 (51) [M+], 276 (6), 185 (9), 167 (100), 152 (19).

HR-MS (EI) $\mathrm{m} / \mathrm{z}$ calcd for $\mathrm{C}_{23} \mathrm{H}_{18} \mathrm{FN}_{3}\left[\mathrm{M}^{+}\right]$355.1485, found 355.1479 .

Synthesis of $\mathbf{N}$-Phenyl- $\mathbf{N - ( 1 - p h e n y l e t h y l ) p y r i m i d i n - 2 - a m i n e ~ ( 8 6 h v " ) ~}$<smiles>CC(c1ccccc1)N(c1ccccc1)c1ncccn1</smiles>

The general procedure D1 was followed using 69a $(128 \mathrm{mg}, 0.75 \mathrm{mmol})$ and $80 \mathrm{v}$ (153 $\mathrm{mg}$, $1.5 \mathrm{mmol}$ ). After purification by column chromatography ( $n$-hexane/EtOAc 9:1) 86hv" (118 mg, 57\%) was obtained as a white solid.

M.p.: $92-93^{\circ} \mathrm{C}$

${ }^{1} \mathbf{H}$ NMR $\left(600 \mathrm{MHz}, \mathrm{CDCl}_{3}\right): \delta=8.30(\mathrm{~d}, J=4.8 \mathrm{~Hz}, 2 \mathrm{H}), 7.30-7.19(\mathrm{~m}, 8 \mathrm{H}), 6.84-6.79(\mathrm{~m}$, $2 \mathrm{H}), 6.54-6.47(\mathrm{~m}, 2 \mathrm{H}), 1.51(\mathrm{~d}, J=7.2 \mathrm{~Hz}, 3 \mathrm{H})$. 
${ }^{13} \mathrm{C}$ NMR $\left(125 \mathrm{MHz}, \mathrm{CDCl}_{3}\right): \delta=162.3\left(\mathrm{C}_{\mathrm{q}}\right), 157.7(\mathrm{CH}), 142.2\left(\mathrm{C}_{\mathrm{q}}\right), 140.1\left(\mathrm{C}_{\mathrm{q}}\right), 130.7(\mathrm{CH})$, $128.8(\mathrm{CH}), 127.9(\mathrm{CH}), 127.8(\mathrm{CH}), 127.1(\mathrm{CH}), 127.0(\mathrm{CH}), 110.5(\mathrm{CH}), 53.7(\mathrm{CH}), 17.7\left(\mathrm{CH}_{3}\right)$.

IR (neat): $\tilde{v}=2978,2931,1597,1547,1431,1064,962,795,698,589 \mathrm{~cm}^{-1}$.

MS (EI): m/z (relative intensity) 275 (38) [M+], 260 (10), 196 (11), 170 (100), 105 (36), 77 (31).

HR-MS (ESI): $\mathrm{m} / \mathrm{z}$ calcd for $\mathrm{C}_{18} \mathrm{H}_{18} \mathrm{~N}_{3}\left[\mathrm{M}+\mathrm{H}^{+}\right]$276.1501, found 276.1500 .

Synthesis of $\mathrm{N}$-(2-Cyclohexylphenyl)pyrimidin-2-amine (86hd) and $\mathrm{N}$-(2,6Dicyclohexylphenyl)pyrimidin-2-amine (86hd')<smiles>c1ccc(C2CCCCC2)c(Nc2nccc(Nc3ncccc3C3CCCCC3)n2)c1</smiles>

The general procedure D2 was followed using 69h (599 mg, $3.5 \mathrm{mmol}$ ) and $80 \mathrm{~d}$ (628 $\mathrm{mg}$, $3.85 \mathrm{mmol}$ ). After purification by column chromatography ( $n$-hexane/EtOAc 95:15) 86hd (362 mg, 54\%) and 86hd' (150 mg, 13\%) were obtained as a white solids.

86hd:

M.p.: $93-94^{\circ} \mathrm{C}$

${ }^{1} \mathrm{H}$ NMR $\left(600 \mathrm{MHz}, \mathrm{CDCl}_{3}\right): \delta=8.36(\mathrm{~d}, J=4.8 \mathrm{~Hz}, 2 \mathrm{H}), 7.73(\mathrm{~d}, J=8.0 \mathrm{~Hz}, 1 \mathrm{H}), 7.31(\mathrm{dd}, J=7.8$, $1.5 \mathrm{~Hz}, 1 \mathrm{H}$ ), 7.23 (ddd, $J=7.8,7.7,1.5 \mathrm{~Hz}, 1 \mathrm{H}$ ), 7.16 (ddd, $J=7.8,7.7,1.2 \mathrm{~Hz}, 1 \mathrm{H}$ ), $6.98(\mathrm{~s}, 1 \mathrm{H}$ ), $6.66(\mathrm{t}, J=4.8 \mathrm{~Hz}, 1 \mathrm{H}), 2.76(\mathrm{tt}, J=11.8,3.0 \mathrm{~Hz}, 1 \mathrm{H}), 1.88-1.80(\mathrm{~m}, 4 \mathrm{H}), 1.75(\mathrm{~d}, J=12.8 \mathrm{~Hz}$, $1 \mathrm{H}), 1.49-1.33(\mathrm{~m}, 4 \mathrm{H}), 1.27(\mathrm{dtt}, J=12.9,12.7,3.4 \mathrm{~Hz}, 1 \mathrm{H})$.

${ }^{13} \mathrm{C}$ NMR $\left(125 \mathrm{MHz}, \mathrm{CDCl}_{3}\right): \delta=161.2\left(\mathrm{C}_{\mathrm{q}}\right), 158.0(\mathrm{CH}), 140.1\left(\mathrm{C}_{\mathrm{q}}\right), 135.5\left(\mathrm{C}_{\mathrm{q}}\right), 126.4(\mathrm{CH})$, $126.1(\mathrm{CH}), 125.1(\mathrm{CH}), 124.4(\mathrm{CH}), 112.0(\mathrm{CH}), 38.6(\mathrm{CH}), 33.6\left(\mathrm{CH}_{2}\right), 27.0\left(\mathrm{CH}_{2}\right), 26.3\left(\mathrm{CH}_{2}\right)$.

IR (neat): $\tilde{v}=3224,2922,2848,1571,1516,1442,1402,1253,799,752 \mathrm{~cm}^{-1}$.

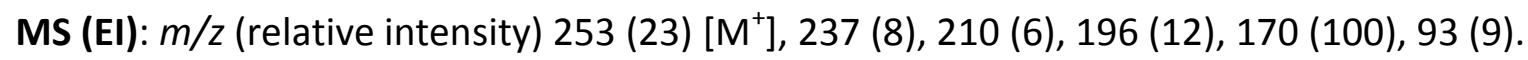

HR-MS (EI): $\mathrm{m} / \mathrm{z}$ calcd for $\mathrm{C}_{16} \mathrm{H}_{19} \mathrm{~N}_{3}\left[\mathrm{M}^{+}\right]$253.1579, found 253.1586.

86hd' 
M.p.: $205-206^{\circ} \mathrm{C}$

${ }^{1} \mathbf{H}$ NMR $\left(600 \mathrm{MHz}, \mathrm{CDCl}_{3}\right): \delta=8.27(\mathrm{~d}, J=4.8 \mathrm{~Hz}, 2 \mathrm{H}), 7.31(\mathrm{t}, J=7.7 \mathrm{~Hz}, 1 \mathrm{H}), 7.21(\mathrm{~d}, J=7.7$ $\mathrm{Hz}, 2 \mathrm{H}), 6.85(\mathrm{~s}, 1 \mathrm{H}), 6.57(\mathrm{t}, J=4.8 \mathrm{~Hz}, 1 \mathrm{H}), 2.77(\mathrm{t}, J=11.7 \mathrm{~Hz}, 2 \mathrm{H}), 1.84-1.68(\mathrm{~m}, 5 \mathrm{H}), 1.45$ $-1.12(\mathrm{~m}, 5 \mathrm{H})$.

${ }^{13} \mathrm{C}$ NMR $\left(125 \mathrm{MHz}, \mathrm{CDCl}_{3}\right): \delta=162.8\left(\mathrm{C}_{\mathrm{q}}\right), 158.3(\mathrm{CH}), 146.0\left(\mathrm{C}_{\mathrm{q}}\right), 132.9\left(\mathrm{C}_{\mathrm{q}}\right), 128.0(\mathrm{CH})$, 124.4 (CH), $111.2(\mathrm{CH}), 39.7(\mathrm{CH}), 34.2\left(\mathrm{CH}_{2}\right), 27.2\left(\mathrm{CH}_{2}\right), 26.4\left(\mathrm{CH}_{2}\right)$.

IR (neat): $\tilde{v}=3222,2921,2847,1601,1578,1527,1445,1412,777 \mathrm{~cm}^{-1}$.

MS (EI): $m / z$ (relative intensity) $335(4)\left[\mathrm{M}^{+}\right], 280$ (2), 252 (100), 208 (3), 196 (6).

HR-MS (EI): $\mathrm{m} / \mathrm{z}$ calcd for $\mathrm{C}_{22} \mathrm{H}_{29} \mathrm{~N}_{3}\left[\mathrm{M}^{+}\right] 335.2361$, found 335.2348 .

Synthesis of $\boldsymbol{N}$-(2-Cyclohexyl-4-methylphenyl)pyrimidin-2-amine (86ld)<smiles>Cc1ccc(Nc2ncccn2)c(C2CCCCC2)c1</smiles>

The general procedure D3 was followed using $69 \mathrm{l}(185 \mathrm{mg}, 1.0 \mathrm{mmol})$ and $80 \mathrm{~d}(179 \mathrm{mg}$, $1.1 \mathrm{mmol}$ ). After purification by column chromatography ( $n$-hexane/EtOAc 95:5) 86ld (92 mg, $34 \%$ ) was obtained as a white solid.

M.p.: $122-123^{\circ} \mathrm{C}$

${ }^{1} \mathbf{H}$ NMR $\left(600 \mathrm{MHz}, \mathrm{CDCl}_{3}\right): \delta=8.34(\mathrm{~d}, J=4.8 \mathrm{~Hz}, 2 \mathrm{H}), 7.49(\mathrm{~d}, J=8.1 \mathrm{~Hz}, 1 \mathrm{H}), 7.11(\mathrm{~s}, 1 \mathrm{H})$, $7.03(\mathrm{~d}, J=8.1 \mathrm{~Hz}, 1 \mathrm{H}), 6.83(\mathrm{~s}, 1 \mathrm{H}), 6.63(\mathrm{t}, J=4.8 \mathrm{~Hz}, 1 \mathrm{H}), 2.73(\mathrm{tt}, J=11.9,2.7 \mathrm{~Hz}, 1 \mathrm{H}), 2.34$ $(\mathrm{s}, 3 \mathrm{H}), 1.81(\mathrm{~d}, J=10.9 \mathrm{~Hz}, 4 \mathrm{H}), 1.76-1.71(\mathrm{~m}, 1 \mathrm{H}), 1.47-1.40(\mathrm{~m}, 2 \mathrm{H}), 1.39-1.30(\mathrm{~m}, 2 \mathrm{H})$, $1.30-1.21(\mathrm{~m}, 1 \mathrm{H})$.

${ }^{13} \mathrm{C}$ NMR $\left(125 \mathrm{MHz}, \mathrm{CDCl}_{3}\right): \delta=161.8\left(\mathrm{C}_{\mathrm{q}}\right), 158.2(\mathrm{CH}), 141.2\left(\mathrm{C}_{\mathrm{q}}\right), 135.3\left(\mathrm{C}_{\mathrm{q}}\right), 132.9\left(\mathrm{C}_{\mathrm{q}}\right), 127.3$ $(\mathrm{CH}), 127.0(\mathrm{CH}), 125.5(\mathrm{CH}), 111.9(\mathrm{CH}), 38.8(\mathrm{CH}), 33.9\left(\mathrm{CH}_{2}\right), 27.2\left(\mathrm{CH}_{2}\right), 26.5\left(\mathrm{CH}_{2}\right), 21.5$ $\left(\mathrm{CH}_{3}\right)$.

IR (neat): $\tilde{v}=3223,2927,2848,1597,1520,1447,1410,797,639 \mathrm{~cm}^{-1}$.

MS (EI): m/z (relative intensity) 267 (18) [M+], 251 (5), 210 (6), 184 (100), 144 (3), 107 (8).

HR-MS (EI): $\mathrm{m} / \mathrm{z}$ calcd for $\mathrm{C}_{17} \mathrm{H}_{21} \mathrm{~N}_{3}\left[\mathrm{M}^{+}\right]$267.1735, found 267.1731. 
Synthesis of $\boldsymbol{N}$-(2-Cyclohexyl-4-fluorophenyl)pyrimidin-2-amine (86kd)<smiles>Fc1ccc(Nc2ncccn2)c(C2CCCCC2)c1</smiles>

The general procedure D3 was followed using 69k (189 mg, $1.0 \mathrm{mmol})$ and $80 \mathrm{~d}(179 \mathrm{mg}$, $1.1 \mathrm{mmol}$ ). After purification by column chromatography ( $n$-hexane/EtOAc 95:5) 86kd (162 mg, 60\%) was obtained as a white solid.

M.p.: $119-120^{\circ} \mathrm{C}$

${ }^{1} \mathrm{H}$ NMR $\left(600 \mathrm{MHz}, \mathrm{CDCl}_{3}\right): \delta=8.32(\mathrm{~d}, J=4.8 \mathrm{~Hz}, 2 \mathrm{H}), 7.54(\mathrm{dd}, J=8.8,5.6 \mathrm{~Hz}, 1 \mathrm{H}), 6.98(\mathrm{dd}, J$ $=10.2,3.0 \mathrm{~Hz}, 1 \mathrm{H}), 6.89(\mathrm{td}, J=8.3,3.0 \mathrm{~Hz}, 1 \mathrm{H}), 6.83(\mathrm{~s}, 1 \mathrm{H}), 6.64(\mathrm{t}, J=4.8 \mathrm{~Hz}, 1 \mathrm{H}), 2.72(\mathrm{t}, J$ $=10.3 \mathrm{~Hz}, 1 \mathrm{H}), 1.84-1.76(\mathrm{~m}, 4 \mathrm{H}), 1.75-1.69(\mathrm{~m}, 1 \mathrm{H}), 1.40-1.18(\mathrm{~m}, 5 \mathrm{H})$.

${ }^{13} \mathrm{C}$ NMR $\left(125 \mathrm{MHz}, \mathrm{CDCl}_{3}\right): \delta=161.6\left(\mathrm{C}_{\mathrm{q}}\right), 160.5\left(\mathrm{C}_{\mathrm{q}},{ }^{1} \mathrm{~J}_{\mathrm{C}-\mathrm{F}}=243.2 \mathrm{~Hz}\right), 158.2(\mathrm{CH}), 144.1\left(\mathrm{C}_{\mathrm{q}}\right.$, $\left.{ }^{3} J_{C-F}=6.6 \mathrm{~Hz}\right), 131.5\left(\mathrm{C}_{q},{ }^{4} J_{\mathrm{C}-\mathrm{F}}=2.2 \mathrm{~Hz}\right), 127.2\left(\mathrm{C}_{q},{ }^{3} J_{\mathrm{C}-\mathrm{F}}=7.8 \mathrm{~Hz}\right), 113.4\left(\mathrm{CH},{ }^{2} J_{\mathrm{C}-\mathrm{F}}=22.4 \mathrm{~Hz}\right)$, $113.0\left(\mathrm{CH},{ }^{2} J_{\mathrm{C}-\mathrm{F}}=21.5 \mathrm{~Hz}\right), 112.2(\mathrm{CH}), 39.0\left(\mathrm{CH},{ }^{4} J_{\mathrm{C}-\mathrm{F}}=1.5 \mathrm{~Hz}\right), 33.7\left(\mathrm{CH}_{2}\right), 27.0\left(\mathrm{CH}_{2}\right), 26.3$ $\left(\mathrm{CH}_{2}\right)$.

${ }^{19}$ F NMR $\left(376 \mathrm{MHz}, \mathrm{CDCl}_{3}\right): \delta=-116.51$ (ddd, $\left.J=10.2,5.6,1.5 \mathrm{~Hz}\right)$.

IR (neat): $\tilde{v}=3232,2924,2850,1575,1518,1445,1403,1259,1191,799 \mathrm{~cm}^{-1}$.

MS (EI): $m / z$ (relative intensity) $271(24)\left[\mathrm{M}^{+}\right], 255$ (8), 243 (5), 214 (11), 201 (6), 188 (100), $161(6)$.

HR-MS (EI): $\mathrm{m} / \mathrm{z}$ calcd for $\mathrm{C}_{16} \mathrm{H}_{18} \mathrm{FN}_{3}\left[\mathrm{M}^{+}\right]$271.1485, found 271.1496.

\section{Synthesis of $\boldsymbol{N}$-(2-Cyclohexyl-3,4,5-trifluorophenyl)pyrimidin-2-amine (86id)}<smiles>Fc1cc(Nc2ncccn2)c(C2CCCCC2)c(F)c1F</smiles> 
The general procedure D2 was followed using 69i $(225 \mathrm{mg}, 1.0 \mathrm{mmol}$ ) and $80 \mathrm{~d}(179 \mathrm{mg}$, $1.1 \mathrm{mmol}$ ). After purification by column chromatography ( $n$-hexane/EtOAc 9:1) 86id (19 mg, 6\%) was obtained as a white solid.

M.p.: $92-93^{\circ} \mathrm{C}$

${ }^{1} \mathbf{H}$ NMR $\left(600 \mathrm{MHz}, \mathrm{CDCl}_{3}\right): \delta=8.39(\mathrm{~d}, J=4.7 \mathrm{~Hz}, 2 \mathrm{H}), 7.45(\mathrm{ddd}, J=11.6,7.0,2.0 \mathrm{~Hz}, 1 \mathrm{H})$, $6.88(\mathrm{~s}, 1 \mathrm{H}), 6.75(\mathrm{t}, J=4.7 \mathrm{~Hz}, 1 \mathrm{H}), 2.80(\mathrm{t}, J=12.2 \mathrm{~Hz}, 1 \mathrm{H}), 1.89-1.79(\mathrm{~m}, 4 \mathrm{H}), 1.76-1.70$ $(\mathrm{m}, 3 \mathrm{H}), 1.32-1.24(\mathrm{~m}, 3 \mathrm{H})$.

${ }^{13} \mathrm{C}$ NMR $\left(125 \mathrm{MHz}, \mathrm{CDCl}_{3}\right): \delta=160.8\left(\mathrm{C}_{\mathrm{q}}\right), 158.3(\mathrm{CH}), 125.4\left(\mathrm{C}_{\mathrm{q}}, J_{\mathrm{C}-\mathrm{F}}=10.9,3.9,1.2 \mathrm{~Hz}\right)$, $113.1(\mathrm{CH}), 108.8\left(\mathrm{CH}, J_{\mathrm{C}-\mathrm{F}}=20.2,3.0 \mathrm{~Hz}\right), 38.0(\mathrm{CH}), 31.0\left(\mathrm{CH}_{2}, J_{\mathrm{C}-\mathrm{F}}=3.6 \mathrm{~Hz}\right), 27.2\left(\mathrm{CH}_{2}\right), 26.0$ $\left(\mathrm{CH}_{2}\right)$. [4 $\mathrm{C}_{\mathrm{q}}$ not observed]

${ }^{19}$ F NMR $\left(283 \mathrm{MHz}, \mathrm{CDCl}_{3}\right): \delta=-135.47(\mathrm{~d}, J=20.0 \mathrm{~Hz}),-138.02(\mathrm{ddd}, J=21.8,11.8,6.3 \mathrm{~Hz}),-$ 164.35 (ddd, $J=21.2,21.07 .1 \mathrm{~Hz}$ ).

IR (neat): $\tilde{v}=3225,2937,2848,1585,1505,1443,1409,1117,939,625 \mathrm{~cm}^{-1}$.

MS (EI): $m / z$ (relative intensity) 307 (18) [M+], 291 (4), 250 (8), 237 (5), 224 (100), 161 (8).

HR-MS (EI): $\mathrm{m} / \mathrm{z}$ calcd for $\mathrm{C}_{16} \mathrm{H}_{16} \mathrm{~F}_{3} \mathrm{~N}_{3}\left[\mathrm{M}^{+}\right]$307.1296, found 307.1289.

Synthesis of $\mathbf{N}$-(2-Cyclohexyl-5-fluorophenyl)pyrimidin-2-amine (86jd) and $\mathbf{N}-(2,6-$ Dicyclohexyl-3-fluorophenyl)pyrimidin-2-amine (86jd')<smiles>Fc1ccc(C2CCCCC2)c(Nc2ncccn2)c1</smiles>

The general procedure D2 was followed using 69j $(95 \mathrm{mg}, 0.5 \mathrm{mmol}$ ) and $80 \mathrm{~d}$ (90 mg, $0.55 \mathrm{mmol}$ ). After purification by column chromatography ( $n$-hexane/EtOAc 95:5) 86jd (33 mg, 26\%) was obtained as a clear oil and 86jd' (63 mg, 18\%) was obtained as a white solid.

86la:

${ }^{1} \mathrm{H}$ NMR $\left(600 \mathrm{MHz}, \mathrm{CDCl}_{3}\right): \delta=8.42(\mathrm{~d}, J=4.8 \mathrm{~Hz}, 2 \mathrm{H}), 7.84(\mathrm{dd}, J=11.3,2.7 \mathrm{~Hz}, 1 \mathrm{H}), 7.20$ (dd, $J=8.7,6.5 \mathrm{~Hz}, 1 \mathrm{H}), 6.98(\mathrm{~s}, 1 \mathrm{H}), 6.80(\mathrm{ddd}, J=8.3,8.3,2.7 \mathrm{~Hz}, 1 \mathrm{H}), 6.74(\mathrm{t}, J=4.8 \mathrm{~Hz}, 1 \mathrm{H})$, $2.66(\mathrm{t}, J=9.0 \mathrm{~Hz}, 1 \mathrm{H}), 1.88-1.83(\mathrm{~m}, 4 \mathrm{H}), 1.77(\mathrm{dd}, J=13.3,3.4 \mathrm{~Hz}, 1 \mathrm{H}), 1.45-1.39(\mathrm{~m}, 4 \mathrm{H})$, $1.31-1.24(\mathrm{~m}, 1 \mathrm{H})$. 
${ }^{13} \mathrm{C}$ NMR $\left(125 \mathrm{MHz}, \mathrm{CDCl}_{3}\right): \delta=161.0\left(\mathrm{C}_{\mathrm{q}},{ }^{1} \mathrm{~J}_{\mathrm{C}-\mathrm{F}}=241.6 \mathrm{~Hz}\right), 160.5\left(\mathrm{C}_{\mathrm{q}}\right), 158.2(\mathrm{CH}), 137.1\left(\mathrm{C}_{\mathrm{q}}\right.$, $\left.{ }^{3} J_{C-F}=10.1 \mathrm{~Hz}\right), 133.5\left(\mathrm{C}_{\mathrm{q}},{ }^{4} \mathrm{~J}_{\mathrm{C}-\mathrm{F}}=3.4 \mathrm{~Hz}\right), 127.3\left(\mathrm{CH},{ }^{3} \mathrm{~J}_{\mathrm{C}-\mathrm{F}}=9.3 \mathrm{~Hz}\right), 112.9(\mathrm{CH}), 110.7\left(\mathrm{CH},{ }^{2} \mathrm{~J}_{\mathrm{C}-\mathrm{F}}\right.$ $=21.4 \mathrm{~Hz}), 109.5\left(\mathrm{CH},{ }^{2} \mathrm{~J}_{\mathrm{C}-\mathrm{F}}=25.1 \mathrm{~Hz}\right), 38.4(\mathrm{CH}), 33.9\left(\mathrm{CH}_{2}\right), 27.2\left(\mathrm{CH}_{2}\right), 26.4\left(\mathrm{CH}_{2}\right)$.

${ }^{19}$ F NMR $\left(283 \mathrm{MHz}, \mathrm{CDCl}_{3}\right): \delta=-116.08(\mathrm{ddd}, J=11.8,11.0,7.2 \mathrm{~Hz})$.

IR (neat): $\tilde{v}=3444,2924,2851,1577,1519,1445,1401,1161,992,797 \mathrm{~cm}^{-1}$.

MS (EI): $m / z$ (relative intensity) 271 (48) $\left[\mathrm{M}^{+}\right], 255$ (11), 242 (9), 228 (10), 214 (23), 201 (12), 188 (100), 161 (27).

HR-MS (EI): $\mathrm{m} / \mathrm{z}$ calcd for $\mathrm{C}_{16} \mathrm{H}_{18} \mathrm{FN}_{3}\left[\mathrm{M}^{+}\right]$271.1485, found 271.1490.

\section{6la'}

M.p.: $210-211^{\circ} \mathrm{C}$

${ }^{1} \mathrm{H}$ NMR $\left(600 \mathrm{MHz}, \mathrm{CDCl}_{3}\right): \delta=8.32(\mathrm{~s}, 2 \mathrm{H}), 7.13(\mathrm{dd}, J=8.7,5.9 \mathrm{~Hz}, 1 \mathrm{H}), 6.98(\mathrm{dd}, J=11.0$, $8.8 \mathrm{~Hz}, 1 \mathrm{H}), 6.62(\mathrm{t}, J=4.8 \mathrm{~Hz}, 1 \mathrm{H}), 6.47(\mathrm{~s}, 1 \mathrm{H}), 2.80(\mathrm{t}, J=12.2 \mathrm{~Hz}, 1 \mathrm{H}), 2.70(\mathrm{t}, J=11.4 \mathrm{~Hz}$, $1 \mathrm{H}), 1.89-1.63(\mathrm{~m}, 12 \mathrm{H}), 1.39-1.11(\mathrm{~m}, 7 \mathrm{H}), 1.06-0.94(\mathrm{~m}, 1 \mathrm{H})$.

${ }^{13} \mathrm{C}$ NMR (125 MHz, CDCl $): \delta=162.7\left(\mathrm{C}_{\mathrm{q}}\right), 160.6\left(\mathrm{C}_{\mathrm{q}},{ }^{1} \mathrm{~J}_{\mathrm{C}-\mathrm{F}}=241.5 \mathrm{~Hz}\right), 158.4(\mathrm{CH}), 141.8\left(\mathrm{C}_{\mathrm{q}}\right.$, $\left.{ }^{4} J_{\mathrm{C}-\mathrm{F}}=2.9 \mathrm{~Hz}\right), 134.3\left(\mathrm{C}_{\mathrm{q}},{ }^{3} \mathrm{~J}_{\mathrm{C}-\mathrm{F}}=7.7 \mathrm{~Hz}\right), 132.9\left(\mathrm{C}_{\mathrm{q}},{ }^{2} \mathrm{~J}_{\mathrm{C}-\mathrm{F}}=13.2 \mathrm{~Hz}\right), 125.1\left(\mathrm{CH},{ }^{3} J_{\mathrm{C}-\mathrm{F}}=10.2 \mathrm{~Hz}\right)$, $115.8\left(\mathrm{CH},{ }^{2} J_{\mathrm{C}-\mathrm{F}}=23.5 \mathrm{~Hz}\right), 111.7(\mathrm{CH}), 39.5(\mathrm{CH}), 39.2(\mathrm{CH}), 34.3\left(\mathrm{CH}_{2}\right), 30.9\left(\mathrm{CH}_{2}\right), 27.3\left(\mathrm{CH}_{2}\right)$, $27.2\left(\mathrm{CH}_{2}\right), 26.4\left(\mathrm{CH}_{2}\right), 26.2\left(\mathrm{CH}_{2}\right)$.

${ }^{19}$ F NMR $\left(283 \mathrm{MHz}, \mathrm{CDCl}_{3}\right): \delta=-115.62(\mathrm{~d}, J=6.3 \mathrm{~Hz})$.

IR (neat): $\tilde{v}=3217,2919,2848,1579,1446,1260,1226,1042,811,641 \mathrm{~cm}^{-1}$.

MS (EI): m/z (relative intensity) 353 (5) [M+], 298 (2), 270 (100), 226 (3), 214 (6), 200 (5).

HR-MS (EI): $\mathrm{m} / \mathrm{z}$ calcd for $\mathrm{C}_{22} \mathrm{H}_{28} \mathrm{FN}_{3}\left[\mathrm{M}^{+}\right]$353.2267, found 353.2280.

\section{Synthesis of $N$-[2-(Nonan-5-yl)phenyl]pyrimidin-2-amine (86ht)}<smiles>CCCCC(CCCC)c1ccccc1Nc1ncccn1</smiles> 
The general procedure D2 was followed using $69 \mathrm{~h}(128 \mathrm{mg}, 0.75 \mathrm{mmol})$ and $80 \mathrm{t}(171 \mathrm{mg}$, $0.83 \mathrm{mmol}$ ). After purification by column chromatography ( $n$-hexane/EtOAc 9:1) $\mathbf{8 6 h t}$ (134 mg, 60\%) was obtained as a white solid.

M.p.: $68-69^{\circ} \mathrm{C}$

${ }^{1} \mathrm{H}$ NMR $\left(400 \mathrm{MHz}, \mathrm{CDCl}_{3}\right): \delta=8.33(\mathrm{~d}, J=4.8 \mathrm{~Hz}, 2 \mathrm{H}), 7.67(\mathrm{~d}, J=7.7 \mathrm{~Hz}, 1 \mathrm{H}), 7.23-7.13(\mathrm{~m}$, $3 \mathrm{H}), 6.76(\mathrm{~s}, 1 \mathrm{H}), 6.63(\mathrm{t}, J=4.8 \mathrm{~Hz}, 1 \mathrm{H}), 2.84(\mathrm{tt}, J=8.7,5.8 \mathrm{~Hz}, 1 \mathrm{H}), 1.67-1.49(\mathrm{~m}, 4 \mathrm{H}), 1.25$ $-1.04(\mathrm{~m}, 8 \mathrm{H}), 0.76(\mathrm{t}, J=7.1 \mathrm{~Hz}, 6 \mathrm{H})$.

${ }^{13} \mathrm{C}$ NMR $\left(75 \mathrm{MHz}, \mathrm{CDCl}_{3}\right): \delta=161.5\left(\mathrm{C}_{\mathrm{q}}\right), 158.4(\mathrm{CH}), 139.7\left(\mathrm{C}_{\mathrm{q}}\right), 136.7\left(\mathrm{C}_{\mathrm{q}}\right), 127.1(\mathrm{CH}), 126.2$ $(\mathrm{CH}), 125.6(\mathrm{CH}), 125.2(\mathrm{CH}), 112.2(\mathrm{CH}), 39.2(\mathrm{CH}), 36.3\left(\mathrm{CH}_{2}\right), 29.9\left(\mathrm{CH}_{2}\right), 23.0\left(\mathrm{CH}_{2}\right), 14.1$ $\left(\mathrm{CH}_{3}\right)$.

IR (neat): $\tilde{v}=3205,2922,2855,1591,1521,1447,1355,995,800,641 \mathrm{~cm}^{-1}$.

MS (EI): m/z (relative intensity) 297 (63) [M+], 254 (92), 240 (63), 226 (44), 196 (27), 184 (66), 170 (100).

HR-MS (EI): $\mathrm{m} / \mathrm{z}$ calcd for $\mathrm{C}_{19} \mathrm{H}_{27} \mathrm{~N}_{3}\left[\mathrm{M}^{+}\right]$297.2205, found 297.2196.

\section{Synthesis of $N$-[2-(2-Adamantyll)phenyl]pyrimidin-2-amine (86hg)}<smiles>c1cnc(Nc2ccccc2C2C3CC4CC(C3)CC2C4)nc1</smiles>

The general procedure D2 was followed using $69 \mathrm{~h}(128 \mathrm{mg}, 0.75 \mathrm{mmol})$ and $80 \mathrm{~g}(177 \mathrm{mg}$, $0.83 \mathrm{mmol}$ ). After purification by column chromatography ( $n$-hexane/EtOAc 95:5) 86hg (126 mg, 55\%) was obtained as a white solid.

M.p.: $130-131^{\circ} \mathrm{C}$

${ }^{1} \mathbf{H}$ NMR $\left(400 \mathrm{MHz}, \mathrm{CDCl}_{3}\right): \delta=8.37(\mathrm{~d}, J=4.8 \mathrm{~Hz}, 2 \mathrm{H}), 7.87(\mathrm{dd}, J=8.0,1.2 \mathrm{~Hz}, 1 \mathrm{H}), 7.58(\mathrm{~d}, J$ $=7.7 \mathrm{~Hz}, 1 \mathrm{H}), 7.28-7.23(\mathrm{~m}, 1 \mathrm{H}), 7.14(\mathrm{ddd}, J=7.9,7.8,1.3 \mathrm{~Hz}, 1 \mathrm{H}), 6.79(\mathrm{~s}, 1 \mathrm{H}), 6.67(\mathrm{t}, J=$ $4.8 \mathrm{~Hz}, 1 \mathrm{H}), 3.16(\mathrm{~s}, 1 \mathrm{H}), 2.27(\mathrm{~s}, 2 \mathrm{H}), 2.09(\mathrm{~s}, 1 \mathrm{H}), 2.05(\mathrm{~s}, 1 \mathrm{H}), 2.01-1.93(\mathrm{~m}, 4 \mathrm{H}), 1.92-$ $1.87(\mathrm{~m}, 1 \mathrm{H}), 1.78(\mathrm{~s}, 2 \mathrm{H}), 1.67(\mathrm{~s}, 1 \mathrm{H}), 1.63(\mathrm{~s}, 2 \mathrm{H})$.

${ }^{13} \mathrm{C}$ NMR $\left(125 \mathrm{MHz}, \mathrm{CDCl}_{3}\right): \delta=160.8\left(\mathrm{C}_{\mathrm{q}}\right), 158.2(\mathrm{CH}), 137.0\left(\mathrm{C}_{\mathrm{q}}\right), 136.8\left(\mathrm{C}_{\mathrm{q}}\right), 127.6(\mathrm{CH})$, $126.2(\mathrm{CH}), 124.1(\mathrm{CH}), 123.8(\mathrm{CH}), 112.2(\mathrm{CH}), 45.2(\mathrm{CH}), 40.2\left(\mathrm{CH}_{2}\right), 37.9\left(\mathrm{CH}_{2}\right), 32.7\left(\mathrm{CH}_{2}\right)$, $31.5(\mathrm{CH}), 28.0(\mathrm{CH}), 27.5(\mathrm{CH})$. 
IR (neat): $\tilde{v}=3224,2899,2845,1579,1519,1443,1407,993,798,641 \mathrm{~cm}^{-1}$.

MS (EI): m/z (relative intensity) 305 (53) [M+], 289 (28), 277 (100), 248 (8), 208 (10), 184 (16), $170(90)$

HR-MS (EI): $\mathrm{m} / \mathrm{z}$ calcd for $\mathrm{C}_{20} \mathrm{H}_{23} \mathrm{~N}_{3}\left[\mathrm{M}^{+}\right]$305.1892, found 305.1879.

Synthesis of $\mathrm{N}$-(2-Cyclohexyl-6-fluorophenyl)pyridin-2-amine (131)<smiles>Fc1cccc(C2CCCCC2)c1Nc1ccccn1</smiles>

The general procedure D2 was followed using $123(94 \mathrm{mg}, 0.5 \mathrm{mmol})$ and $80 \mathrm{~d}(163 \mathrm{mg}$, $1.0 \mathrm{mmol}$ ). After purification by column chromatography ( $n$-hexane/EtOAc $2: 1$ ), followed by GPC, 131 (6 mg, 5\%) was obtained as a brown oil.

${ }^{1}$ H NMR $\left(300 \mathrm{MHz}, \mathrm{CDCl}_{3}\right): \delta=8.16(\mathrm{~s}, 1 \mathrm{H}), 7.42(\mathrm{ddd}, J=8.0,7.7,1.7 \mathrm{~Hz}, 1 \mathrm{H}), 7.25-7.18(\mathrm{~m}$, $1 \mathrm{H}), 7.12(\mathrm{~d}, J=7.5 \mathrm{~Hz}, 1 \mathrm{H}), 6.99$ (ddd, $J=9.6,8.0,1.5 \mathrm{~Hz}, 1 \mathrm{H}), 6.70-6.65(\mathrm{~m}, 1 \mathrm{H}), 6.24(\mathrm{~d}, J$ $=6.8 \mathrm{~Hz}, 1 \mathrm{H}), 6.14(\mathrm{~s}, 1 \mathrm{H}), 2.91-2.79(\mathrm{~m}, 1 \mathrm{H}), 1.85-1.66(\mathrm{~m}, 5 \mathrm{H}), 1.48-1.22(\mathrm{~m}, 5 \mathrm{H})$.

${ }^{13} \mathrm{C}$ NMR $\left(125 \mathrm{MHz}, \mathrm{CDCl}_{3}\right): \delta=158.8\left(\mathrm{C}_{\mathrm{q}},{ }^{1} \mathrm{~J}_{\mathrm{C}-\mathrm{F}}=246.6 \mathrm{~Hz}\right), 157.9\left(\mathrm{C}_{\mathrm{q}}\right), 148.1(\mathrm{CH}), 147.9\left(\mathrm{C}_{\mathrm{q}}\right)$, $137.9(\mathrm{CH}), 127.5\left(\mathrm{CH},{ }^{3} \mathrm{~J}_{\mathrm{C}-\mathrm{F}}=9.1 \mathrm{~Hz}\right), 124.8\left(\mathrm{C}_{\mathrm{q}},{ }^{2} \mathrm{~J}_{\mathrm{C}-\mathrm{F}}=12.2 \mathrm{~Hz}\right), 122.4\left(\mathrm{CH},{ }^{4} J_{\mathrm{C}-\mathrm{F}}=3.5 \mathrm{~Hz}\right)$, $114.6(\mathrm{CH}), 113.6\left(\mathrm{CH},{ }^{2} J_{\mathrm{C}-\mathrm{F}}=20.7 \mathrm{~Hz}\right), 106.7(\mathrm{CH}), 38.9\left(\mathrm{CH},{ }^{4} J_{\mathrm{C}-\mathrm{F}}=2.2 \mathrm{~Hz}\right), 34.1\left(\mathrm{CH}_{2}\right), 27.0$ $\left(\mathrm{CH}_{2}\right), 26.3\left(\mathrm{CH}_{2}\right)$.

${ }^{19} \mathrm{~F} \mathrm{NMR}\left(283 \mathrm{MHz}, \mathrm{CDCl}_{3}\right): \delta=-119.06$ (ddd, $\left.J=9.7,5.5,1.8 \mathrm{~Hz}\right)$.

IR (neat): $\tilde{v}=3206,2926,2852,1599,1523,1446,1325,1259,958,770 \mathrm{~cm}^{-1}$.

MS (ESI): $m / z$ (relative intensity) $271(100)\left[\mathrm{M}^{+}\right], 236$ (9), 201 (1), 159 (3), 130 (2).

HR-MS (ESI): $\mathrm{m} / \mathrm{z}$ calcd for $\mathrm{C}_{17} \mathrm{H}_{20} \mathrm{FN}_{2}\left[\mathrm{M}^{+}\right]$271.1610, found 271.1606.

Synthesis of $\boldsymbol{N}$-(2-Cyclohexyl-6-fluorophenyl)-4-(p-tolyl)pyrimidin-2-amine (129) and 4-(2Cyclohexyl-4-methylphenyl)-N-(2-cyclohexyl-6-fluorophenyl)pyrimidin-2-amine (129') 
<smiles>Cc1ccc(-c2ccnc(Nc3c(F)cccc3C3CCCCC3)n2)cc1</smiles>

The general procedure D1 was followed using $121(279 \mathrm{mg}, 1.0 \mathrm{mmol})$ and $80 \mathrm{~d}(326 \mathrm{mg}$, $2.0 \mathrm{mmol}$ ). After purification by column chromatography ( $n$-hexane/EtOAc 95:5) 129 (262 mg, 72\%) and 129' (50 mg, 11\%) were obtained as white solids.

129:

M.p.: $70-71^{\circ} \mathrm{C}$

${ }^{1} \mathrm{H}$ NMR $\left(600 \mathrm{MHz}, \mathrm{CDCl}_{3}\right): \delta=8.36(\mathrm{~d}, J=5.2 \mathrm{~Hz}, 1 \mathrm{H}), 7.89(\mathrm{~d}, J=8.1 \mathrm{~Hz}, 2 \mathrm{H}), 7.26-7.22(\mathrm{~m}$, $3 \mathrm{H}), 7.12(\mathrm{~d}, J=7.9 \mathrm{~Hz}, 1 \mathrm{H}), 7.08(\mathrm{~d}, J=5.3 \mathrm{~Hz}, 1 \mathrm{H}), 7.00(\mathrm{ddd}, J=9.6,8.1,1.4 \mathrm{~Hz}, 1 \mathrm{H}), 6.57(\mathrm{~s}$, $1 \mathrm{H}), 2.89(\mathrm{tt}, J=11.9,3.2 \mathrm{~Hz}, 1 \mathrm{H}), 2.40(\mathrm{~s}, 3 \mathrm{H}), 1.86-1.80(\mathrm{~m}, 2 \mathrm{H}), 1.80-1.74(\mathrm{~m}, 2 \mathrm{H}), 1.73-$ $1.67(\mathrm{~m}, 1 \mathrm{H}), 1.45-1.36(\mathrm{~m}, 2 \mathrm{H}), 1.35-1.21(\mathrm{~m}, 3 \mathrm{H})$.

${ }^{13} \mathrm{C}$ NMR (76 MHz, $\left.\mathrm{CDCl}_{3}\right): \delta=165.2\left(\mathrm{C}_{\mathrm{q}}\right), 162.1\left(\mathrm{C}_{\mathrm{q}}\right), 158.9\left(\mathrm{C}_{\mathrm{q}},{ }^{1} J_{\mathrm{C}-\mathrm{F}}=246.3 \mathrm{~Hz}\right), 158.7(\mathrm{CH})$, $147.7\left(\mathrm{C}_{\mathrm{q}}\right), 141.1\left(\mathrm{C}_{\mathrm{q}}\right), 134.5\left(\mathrm{C}_{\mathrm{q}}\right), 129.6(\mathrm{CH}), 127.7\left(\mathrm{CH},{ }^{1} J_{\mathrm{C}-\mathrm{F}}=8.8 \mathrm{~Hz}\right), 127.1(\mathrm{CH}), 124.2\left(\mathrm{C}_{\mathrm{q}}\right.$, $\left.{ }^{1} J_{\mathrm{C}-\mathrm{F}}=12.5 \mathrm{~Hz}\right), 122.0\left(\mathrm{CH},{ }^{1} J_{\mathrm{C}-\mathrm{F}}=3.7 \mathrm{~Hz}\right), 113.3\left(\mathrm{CH},{ }^{1} \mathrm{~J}_{\mathrm{C}-\mathrm{F}}=20.7 \mathrm{~Hz}\right), 108.0(\mathrm{CH}), 39.0\left(\mathrm{CH},{ }^{1} \mathrm{~J}_{\mathrm{C}-\mathrm{F}}\right.$ $=2.4 \mathrm{~Hz}), 33.9\left(\mathrm{CH}_{2}\right), 26.9\left(\mathrm{CH}_{2}\right), 26.3\left(\mathrm{CH}_{2}\right), 21.6\left(\mathrm{CH}_{3}\right)$.

${ }^{19}$ F NMR $\left(283 \mathrm{MHz}, \mathrm{CDCl}_{3}\right): \delta=-118.69(\mathrm{dd}, J=9.6,5.5 \mathrm{~Hz})$.

IR (neat): $\tilde{v}=3219,2923,2850,1575,1549,1443,1280,958,801,702 \mathrm{~cm}^{-1}$.

MS (EI): m/z (relative intensity) $361(63)\left[\mathrm{M}^{+}\right], 342$ (14), 304 (13), 278 (100), 251 (14), 237 (12), 184 (16).

HR-MS (EI): $\mathrm{m} / \mathrm{z}$ calcd for $\mathrm{C}_{23} \mathrm{H}_{24} \mathrm{FN}_{3}\left[\mathrm{M}^{+}\right] 361.1954$, found 361.1966 .

129'

M.p.: $162-163^{\circ} \mathrm{C}$

${ }^{1} \mathbf{H}$ NMR $\left(600 \mathrm{MHz}, \mathrm{CDCl}_{3}\right): \delta=8.34(\mathrm{~d}, J=5.0 \mathrm{~Hz}, 1 \mathrm{H}), 7.21(\mathrm{~d}, J=7.8 \mathrm{~Hz}, 1 \mathrm{H}), 7.20-7.17(\mathrm{~m}$, $1 \mathrm{H}), 7.15(\mathrm{~s}, 1 \mathrm{H}), 7.07(\mathrm{~d}, J=7.8 \mathrm{~Hz}, 1 \mathrm{H}), 7.03(\mathrm{~d}, J=6.8 \mathrm{~Hz}, 1 \mathrm{H}), 6.95(\mathrm{dd}, J=8.9,8.7 \mathrm{~Hz}, 1 \mathrm{H})$, $6.72(\mathrm{~d}, J=5.0 \mathrm{~Hz}, 1 \mathrm{H}), 6.49(\mathrm{~s}, 1 \mathrm{H}), 2.89-2.80(\mathrm{~m}, 2 \mathrm{H}), 2.35(\mathrm{~s}, 3 \mathrm{H}), 1.81-1.62(\mathrm{~m}, 10 \mathrm{H})$, $1.43-1.16(\mathrm{~m}, 10 \mathrm{H})$.

${ }^{13} \mathrm{C} \mathrm{NMR}\left(76 \mathrm{MHz}, \mathrm{CDCl}_{3}\right): \delta=169.2\left(\mathrm{C}_{\mathrm{q}}\right), 161.6\left(\mathrm{C}_{\mathrm{q}}\right), 158.9\left(\mathrm{C}_{\mathrm{q}},{ }^{1} \mathrm{~J}_{\mathrm{C}-\mathrm{F}}=247.3 \mathrm{~Hz}\right), 158.0(\mathrm{CH})$, $147.5\left(\mathrm{C}_{\mathrm{q}}\right), 145.8\left(\mathrm{C}_{\mathrm{q}}\right), 139.1\left(\mathrm{C}_{\mathrm{q}}\right), 135.2\left(\mathrm{C}_{\mathrm{q}}\right), 129.3(\mathrm{CH}), 127.7\left(\mathrm{CH}^{3}{ }^{3} \mathrm{C}_{\mathrm{F}}=8.2 \mathrm{~Hz}\right), 127.5(\mathrm{CH})$, 
$126.5(\mathrm{CH}), 124.0\left(\mathrm{C}_{\mathrm{q}},{ }^{2} \mathrm{~J}_{\mathrm{C}-\mathrm{F}}=11.7 \mathrm{~Hz}\right), 122.0\left(\mathrm{C}_{\mathrm{q}},{ }^{3} \mathrm{~J}_{\mathrm{C}-\mathrm{F}}=3.6 \mathrm{~Hz}\right), 113.3\left(\mathrm{CH},{ }^{2} \mathrm{~J}_{\mathrm{C}-\mathrm{F}}=20.2 \mathrm{~Hz}\right)$, $112.7(\mathrm{CH}), 39.8(\mathrm{CH}), 39.1\left(\mathrm{CH},{ }^{4} J_{\mathrm{C}-\mathrm{F}}=2.3 \mathrm{~Hz}\right), 34.6\left(\mathrm{CH}_{2}\right), 33.8\left(\mathrm{CH}_{2}\right), 27.0\left(\mathrm{CH}_{2}\right), 26.9\left(\mathrm{CH}_{2}\right)$, $26.4\left(\mathrm{CH}_{2}\right), 26.3\left(\mathrm{CH}_{2}\right), 21.6\left(\mathrm{CH}_{3}\right)$.

${ }^{19}$ F NMR $\left(283 \mathrm{MHz}, \mathrm{CDCl}_{3}\right): \delta=-118.56(\mathrm{dd}, J=9.7,5.5 \mathrm{~Hz})$.

IR (neat): $\tilde{v}=3219,2921,2849,1576,1556,1415,961,783,708,648 \mathrm{~cm}^{-1}$.

MS (EI): m/z (relative intensity) $443(100)\left[\mathrm{M}^{+}\right], 400$ (6), 388 (6), 360 (67), 319 (6), 226 (15), 208 (6).

HR-MS (EI): $\mathrm{m} / \mathrm{z}$ calcd for $\mathrm{C}_{29} \mathrm{H}_{34} \mathrm{FN}_{3}\left[\mathrm{M}^{+}\right]$443.2737, found 443.2723.

\section{Synthesis of Cyclohexyl-N-phenylmorpholine-4-carbimidothioate (133')}<smiles>c1ccc(/N=C(\SC2CCCCC2)N2CCOCC2)cc1</smiles>

The general procedure D1 was followed using $125(222 \mathrm{mg}, 1.0 \mathrm{mmol})$ and $\mathbf{8 0 d}(326 \mathrm{mg}$, $2.0 \mathrm{mmol}$ ). After purification by column chromatography (n-hexane/EtOAc 3:1) 133' (169 mg, $55 \%)$ was obtained as a yellow oil.

${ }^{1} \mathrm{H}$ NMR $\left(600 \mathrm{MHz}, \mathrm{CDCl}_{3}\right): \delta=7.25-7.21(\mathrm{~m}, 2 \mathrm{H}), 6.97(\mathrm{t}, J=7.4 \mathrm{~Hz}, 1 \mathrm{H}), 6.85(\mathrm{~d}, J=7.4 \mathrm{~Hz}$, $2 \mathrm{H}), 3.73-3.70(\mathrm{~m}, 4 \mathrm{H}), 3.66-3.63(\mathrm{~m}, 4 \mathrm{H}), 2.55(\mathrm{tt}, J=10.7,3.6 \mathrm{~Hz}, 1 \mathrm{H}), 1.74-1.68(\mathrm{~m}$, $2 \mathrm{H}), 1.65-1.57(\mathrm{~m}, 3 \mathrm{H}), 1.52-1.45(\mathrm{~m}, 1 \mathrm{H}), 1.20-1.00(\mathrm{~m}, 5 \mathrm{H})$.

${ }^{13} \mathrm{C} \mathrm{NMR}\left(125 \mathrm{MHz}, \mathrm{CDCl}_{3}\right): \delta=154.7\left(\mathrm{C}_{\mathrm{q}}\right), 150.0\left(\mathrm{C}_{\mathrm{q}}\right), 128.6(\mathrm{CH}), 122.3(\mathrm{CH}), 121.6(\mathrm{CH}), 67.0$ $\left(\mathrm{CH}_{2}\right), 49.0\left(\mathrm{CH}_{2}\right), 45.1(\mathrm{CH}), 33.7\left(\mathrm{CH}_{2}\right), 26.1\left(\mathrm{CH}_{2}\right), 25.7\left(\mathrm{CH}_{2}\right)$.

IR (neat): $\tilde{v}=2926,2851,1577,1447,1194,1111,1022,853,763,694 \mathrm{~cm}^{-1}$.

MS (ESI): m/z (relative intensity) 327 (6), 305 (100) [M+H'], 271 (3), 236 (11), 169 (3).

HR-MS (ESI): $\mathrm{m} / \mathrm{z}$ calcd for $\mathrm{C}_{17} \mathrm{H}_{25} \mathrm{~N}_{2} \mathrm{OS}\left[\mathrm{M}+\mathrm{H}^{+}\right]$305.1687, found 305.1685.

\section{$\underline{\text { Mechanistic studies }}$}


$H / D$ exchange experiments with $[D]_{5}-69 \mathrm{~h}$ as the substrate:

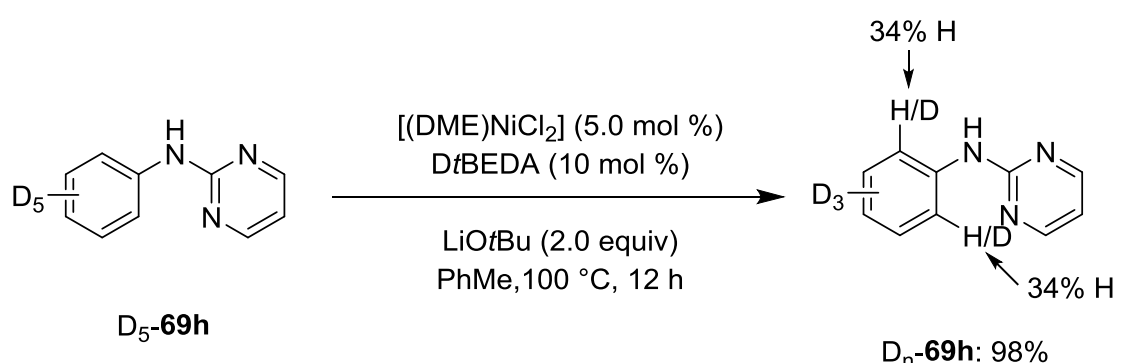

Following the general procedure D1 $[D]_{5}-69 \mathrm{~h}(38 \mathrm{mg}, 0.22 \mathrm{mmol}$ ) was reacted without alkyl halide 80. After $12 \mathrm{~h}$, the reaction was cooled to $0{ }^{\circ} \mathrm{C}$, filtered through a silica pad and concentrated in vacuo, giving $[\mathrm{D}]_{\mathrm{n}}-69 \mathrm{~h}$ (36 mg, 98\%).

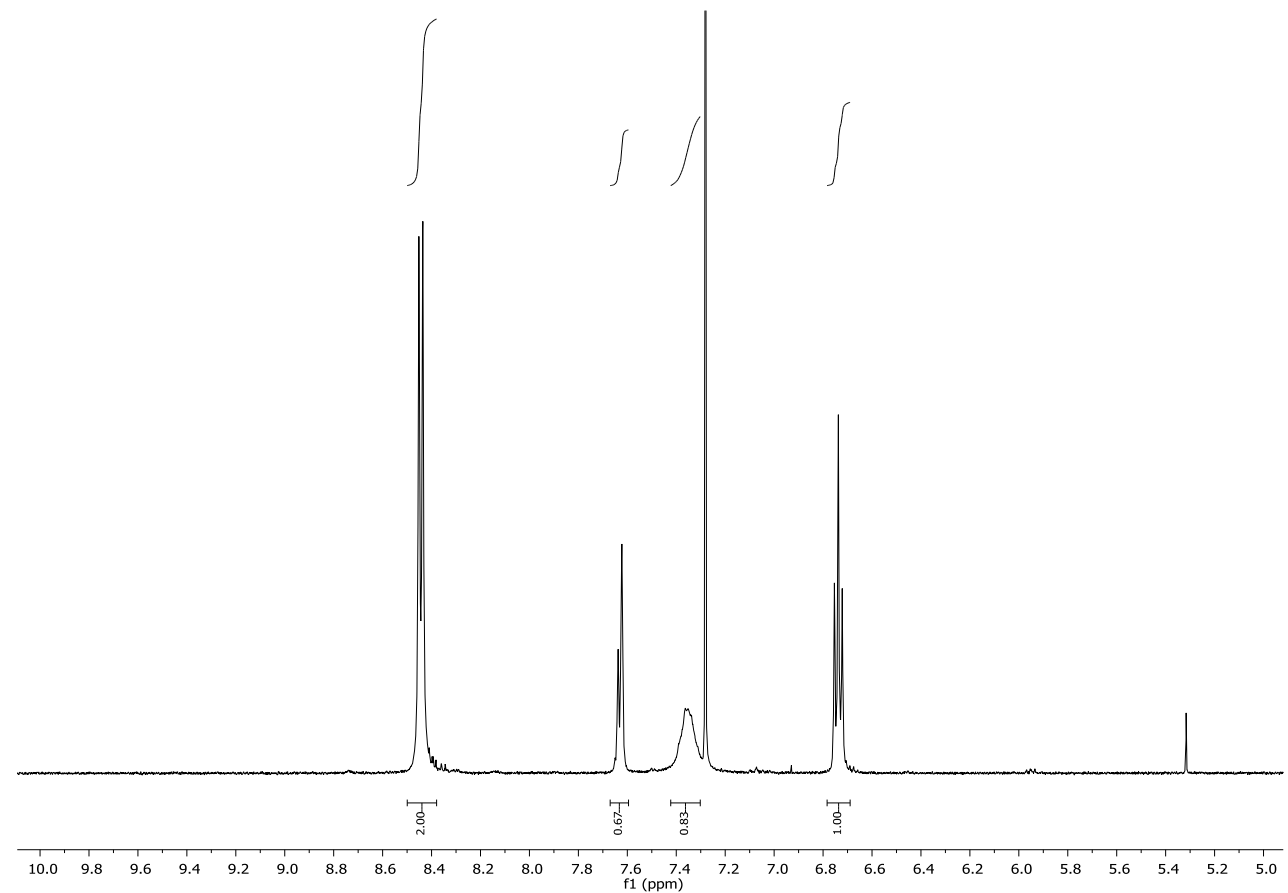

H/D exchange experiments with $69 \mathrm{~h}$ as the substrate:

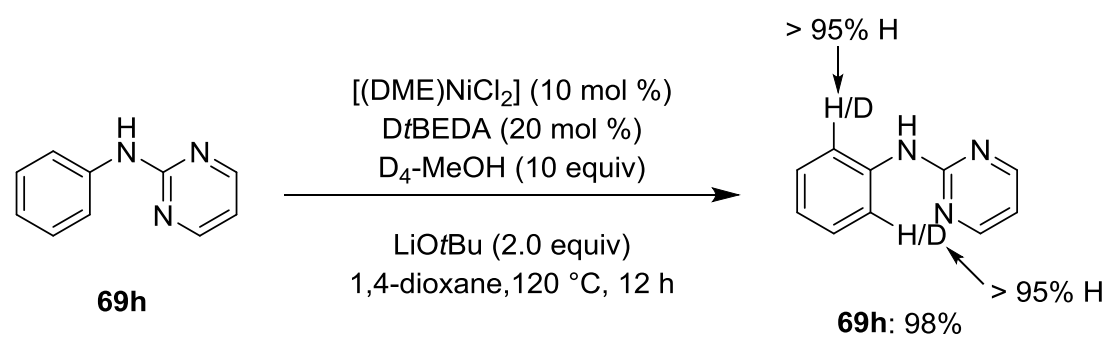


Following the general procedure D1 $69 \mathrm{~h}\left(86 \mathrm{mg}, 0.5 \mathrm{mmol}\right.$ ) was reacted with $\mathrm{D}_{4}-\mathrm{MeOH}$ $(0.2 \mathrm{~mL}, 5.0 \mathrm{mmol})$. After $12 \mathrm{~h}$, the reaction was cooled to $0{ }^{\circ} \mathrm{C}$, filtered through a silica pad and concentrated in vacuo, giving $[D]_{n}-69 h(86 \mathrm{mg}, 98 \%)$.

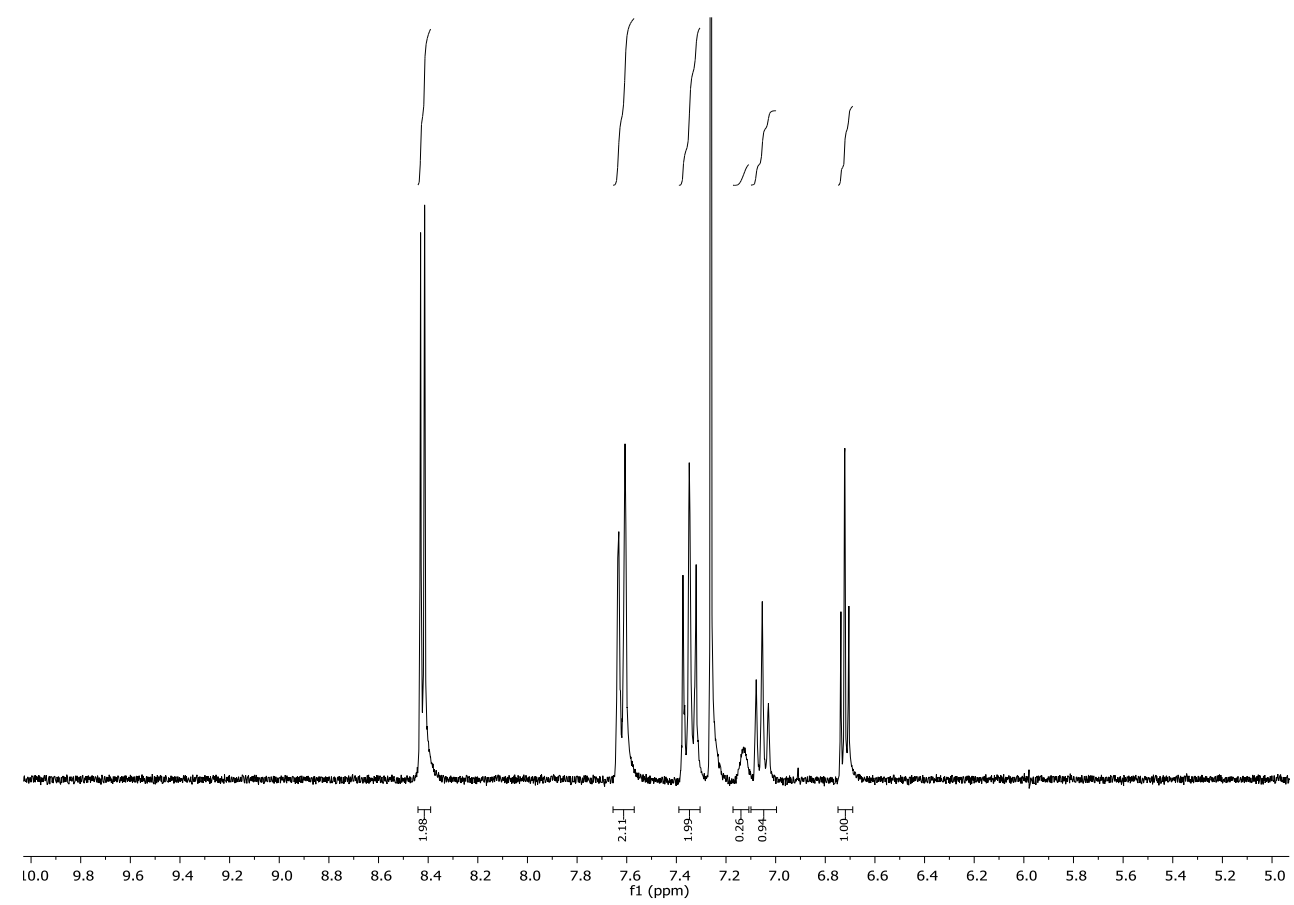

$H / D$ exchange experiments with $[D]_{5}-69 \mathrm{~h}$ and $80 \mathrm{~d}$ as the substrates:

Following the general procedure D2 $[\mathrm{D}]_{5}-69 \mathrm{~h}(88 \mathrm{mg}, 0.5 \mathrm{mmol})$ was reacted with $\mathbf{8 0 d}$ (90 $\mathrm{mg}, 0.55 \mathrm{mmol})$. After $3.5 \mathrm{~h}$, the reaction was cooled with an ice bath, filtered through a silica pad and concentrated in vacuo. The residue was analyzed by ${ }^{1} \mathrm{H}$ NMR spectroscopy. Yields of products were determined using $\mathrm{CH}_{2} \mathrm{Br}_{2}(49.5 \mathrm{mg}, 0.28 \mathrm{mmol})$ as the internal standard.

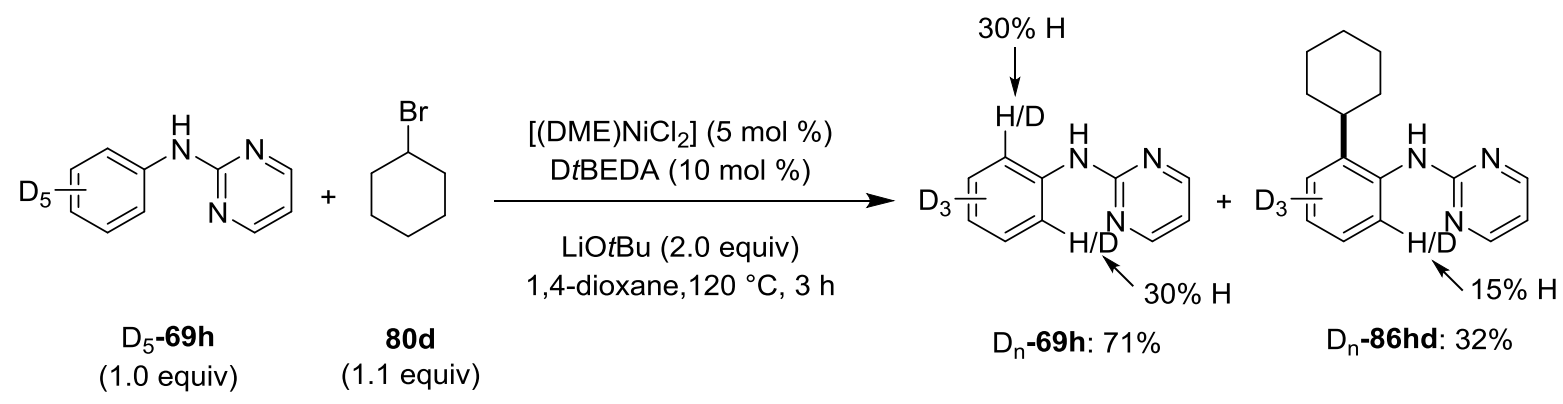




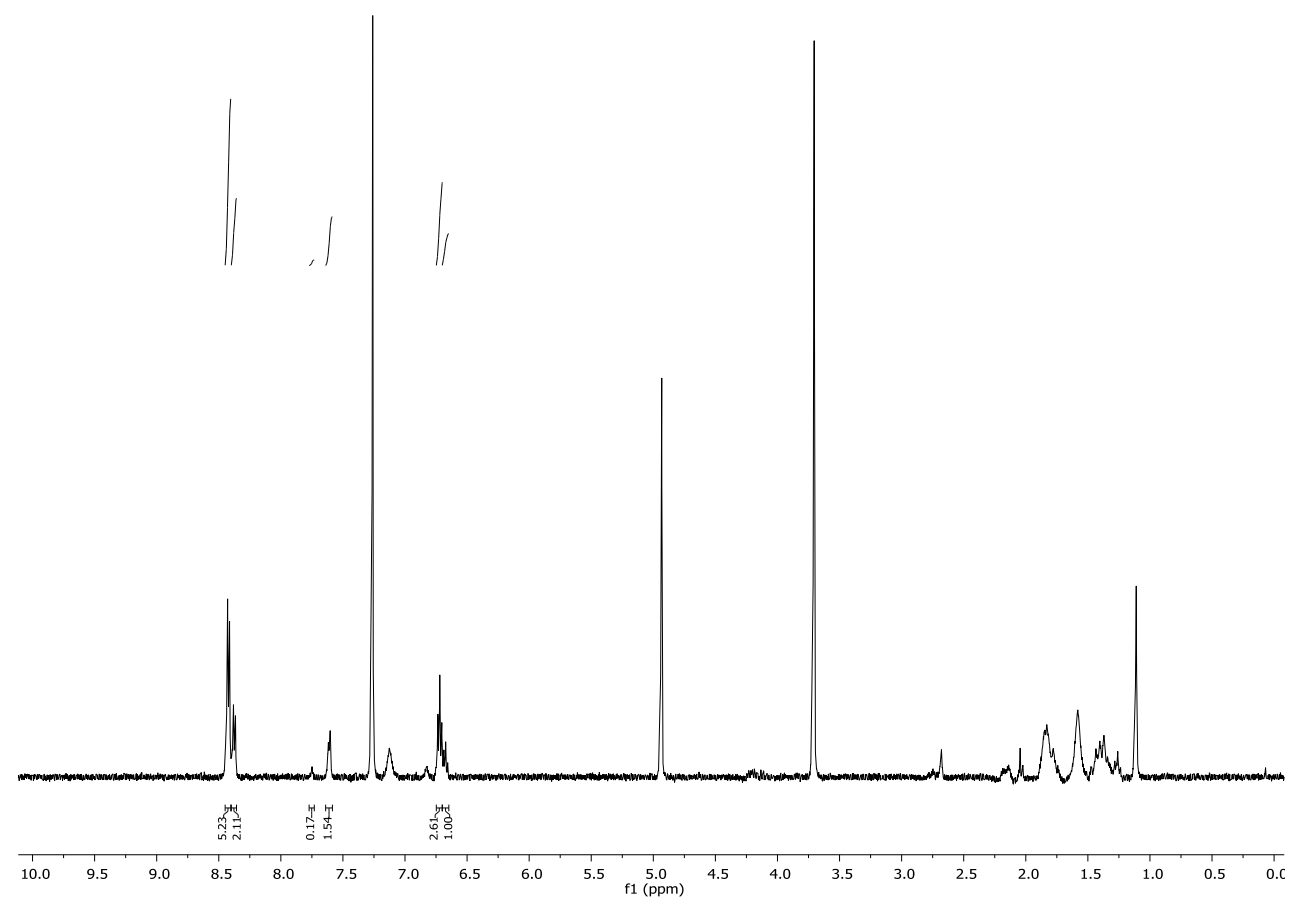

\section{KIE experiments with $69 \mathrm{~h}$ and $[\mathrm{D}]_{5}-69 \mathrm{~h}$ as the substrates}

Parallel independent reactions with $69 \mathrm{~h}$ and $[D]_{5}-69 \mathrm{~h}$ were performed for different reaction times. Following general procedure D1 $69 \mathrm{~h}(86 \mathrm{mg}, 0.5 \mathrm{mmol})$ or [D] ${ }_{5}-69 \mathrm{~h}(88 \mathrm{mg}, 0.5 \mathrm{mmol})$ were reacted with $\mathbf{8 0 d}(90 \mathrm{mg}, 0.55 \mathrm{mmol})$. After the reaction times indicated below, each reaction was cooled with an ice bath, filtered through a silica pad and concentrated in vacuo. The residue was analyzed by ${ }^{1} \mathrm{H}$ NMR spectroscopy. Yields of products were determined using $\mathrm{CH}_{2} \mathrm{Br}_{2}$ (49.5 mg, $0.28 \mathrm{mmol}$ ) as internal standard. For each reaction time the average of two reactions was obtained.<smiles>[SbH3]c1ccc(Nc2ncccn2)cc1</smiles>

$69 \mathrm{~h}$ (1.0 equiv)<smiles>BrC1CCCCC1</smiles>

80d

(1.1 equiv)

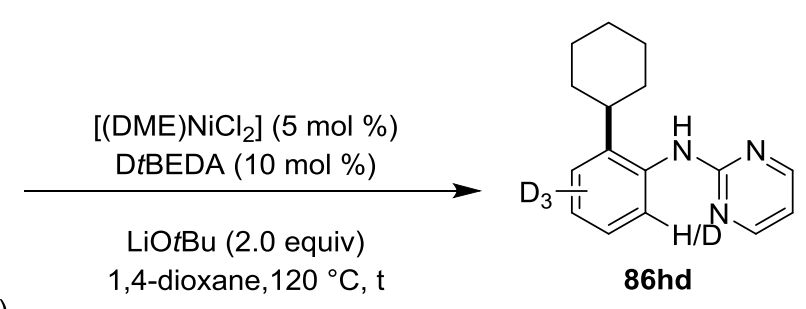

$\mathrm{k}_{\mathrm{H}} / \mathrm{k}_{\mathrm{D}}=1.7$

\begin{tabular}{|c|c|c|c|c|c|c|}
\hline $\mathrm{t}[\mathrm{h}]$ & 1.5 & 2.0 & 2.5 & 3.0 & 3.5 & 4.0 \\
\hline 86hd & 3 & 10 & 17 & 34 & 39 & 53 \\
\hline$[\mathrm{D}]_{n}-\mathbf{8 6 h d}$ & 0 & 7 & 13 & 17 & 20 & 33 \\
\hline
\end{tabular}




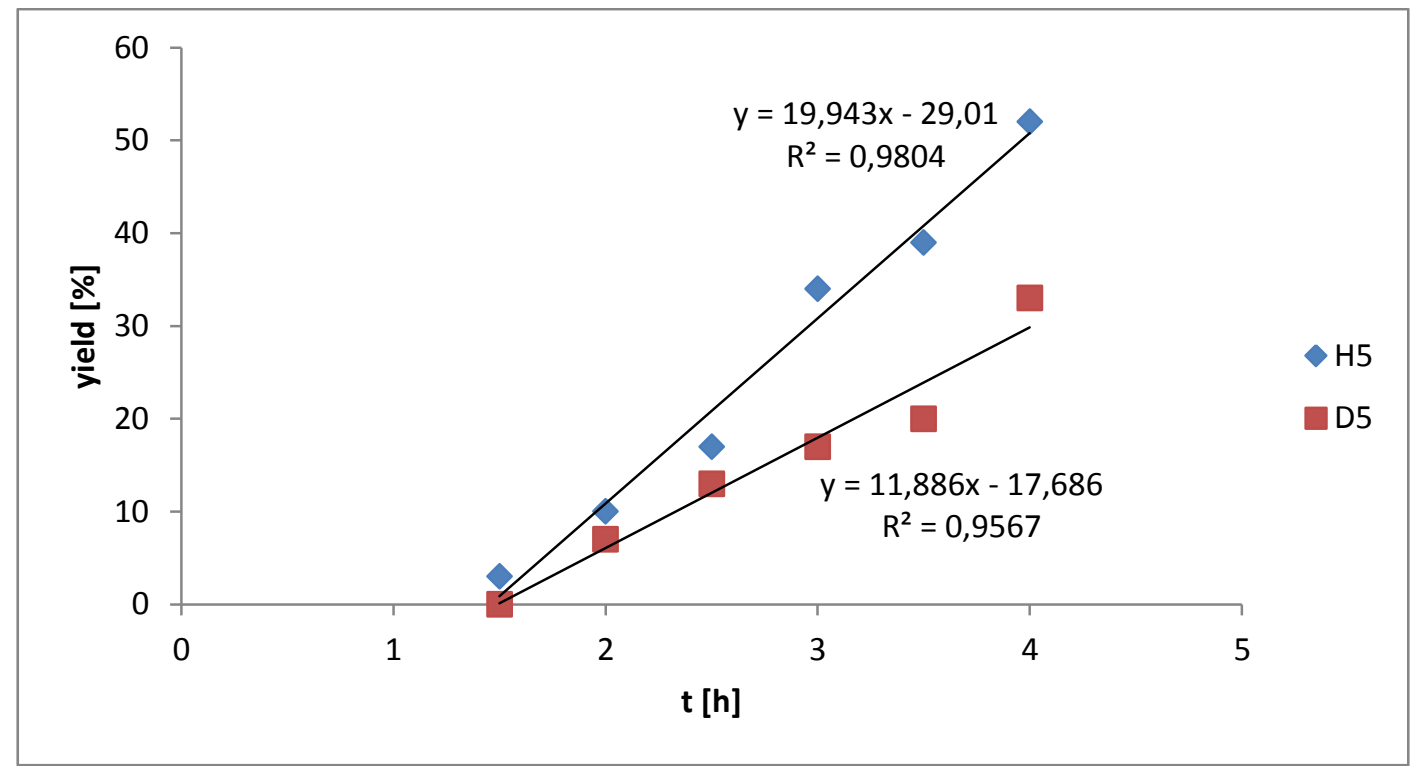

Reaction of aniline 69a with cyclohexene 138<smiles>Fc1ccccc1Nc1ncccn1</smiles>

$69 a$ (1.0 equiv)<smiles>C1=CCCCC1</smiles>

138 (2.0 equiv)

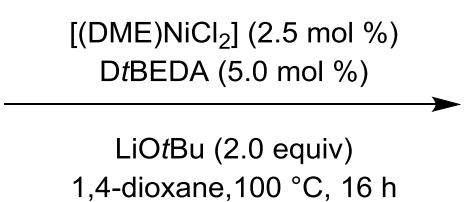

1,4-dioxane, $100{ }^{\circ} \mathrm{C}, 16 \mathrm{~h}$

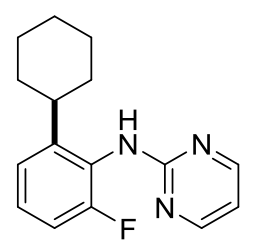

86ad: $0 \%$

Following the general procedure D1 69a (189 mg, $1.0 \mathrm{mmol})$ was reacted with $138(164 \mathrm{mg}$, $2.0 \mathrm{mmol})$. After cooling to ambient temperature, $\mathrm{CH}_{2} \mathrm{Cl}_{2}(2.0 \mathrm{~mL})$ was added. No conversion was observed through ${ }^{19} \mathrm{~F}$ NMR analysis of the crude reaction mixture.

\section{Reaction of aniline 69a with styrene 139}

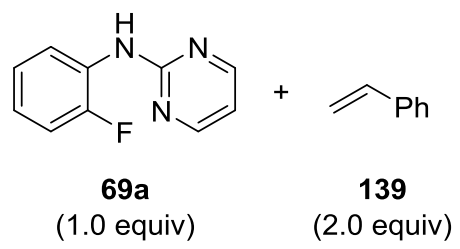

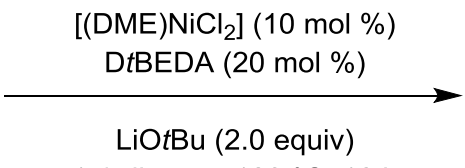

1,4-dioxane, $120^{\circ} \mathrm{C}, 16 \mathrm{~h}$

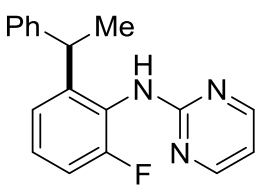

86av: $0 \%$

Following the general procedure D1 69a (189 mg, $1.0 \mathrm{mmol}$ ) was reacted with 139 (208 mg, $2.0 \mathrm{mmol})$. After cooling to ambient temperature, $\mathrm{CH}_{2} \mathrm{Cl}_{2}(2.0 \mathrm{~mL})$ was added. No conversion was observed through ${ }^{19} \mathrm{~F}$ NMR analysis of the crude reaction mixture. 
Reaction of aniline 69a with (S)-2-Bromooctane (80k)

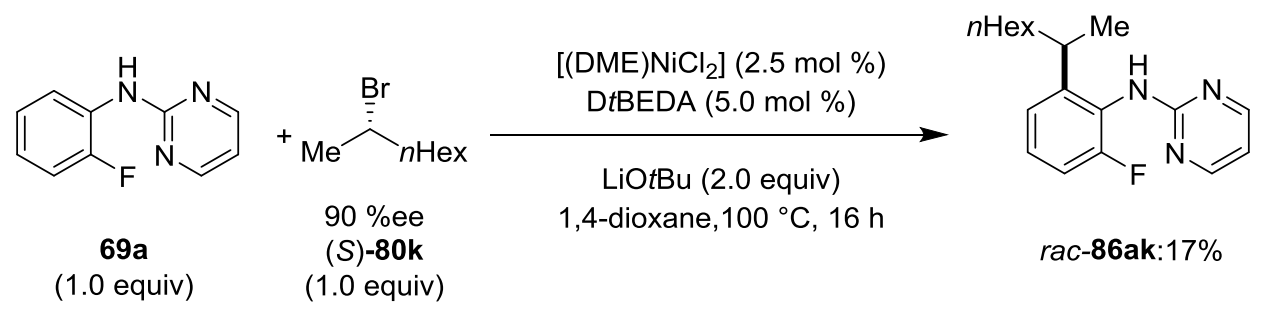

The general procedure D2 was followed using substrate 69a (189 mg, $1.0 \mathrm{mmol}$ ) and (S)-2Bromooctane $(S)$-80k (193 mg, $1.0 \mathrm{mmol})$. Isolation by filtration through a silica pad ( $n$ hexane/EtOAc: $85 / 15$ ) yielded the mixture of 69 a and 86 ak as a white solid. Analysis by HPLC showed 86 ak to be racemic.
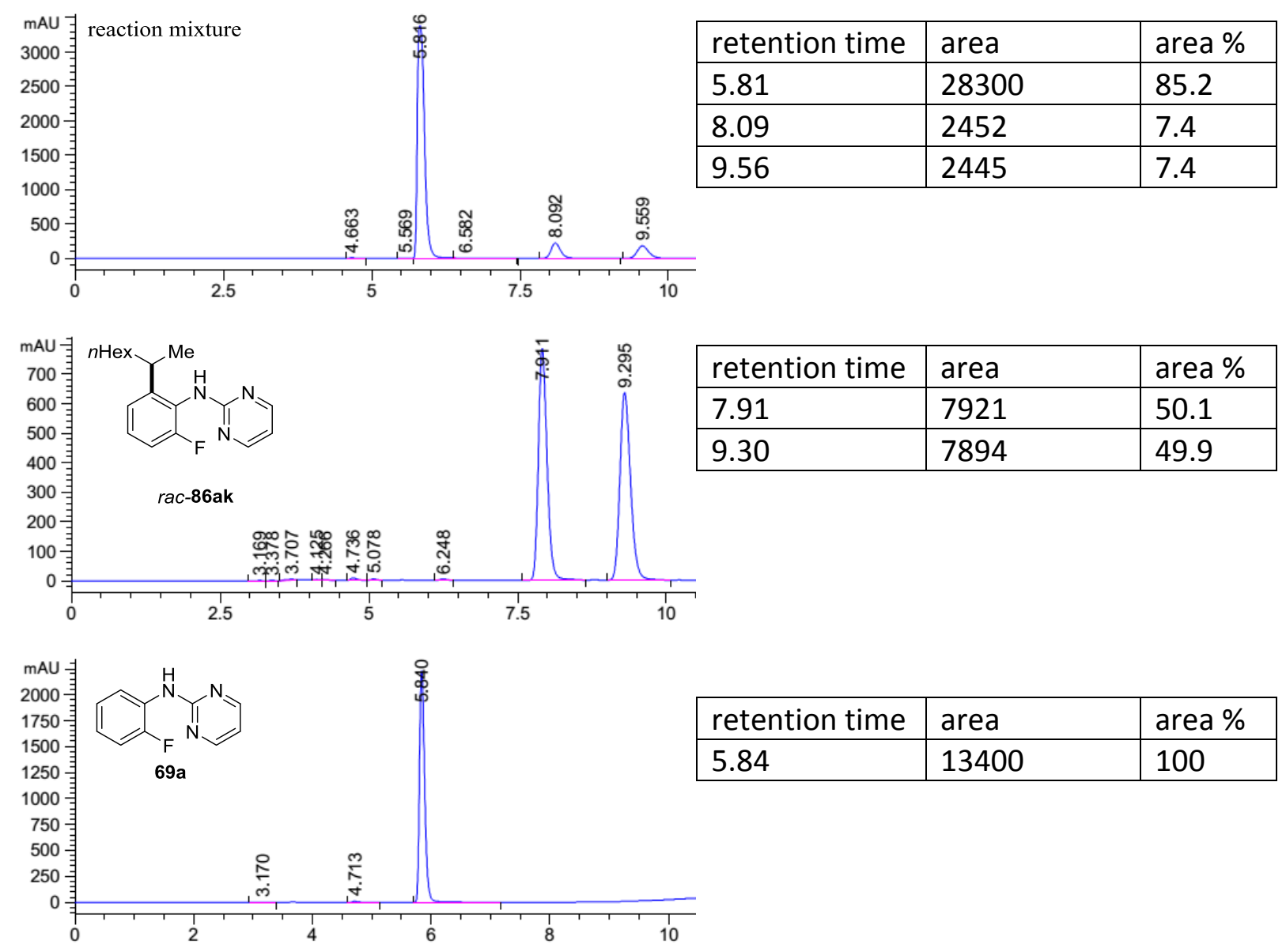


\section{Hammett plot correlation for anilines 69}

The general procedure D2 was followed using anilines 69 (0.50 mmol) and cyclohexylbromide $(\mathbf{8 0 d})(90 \mathrm{mg}, 0.55 \mathrm{mmol})$. After $3 \mathrm{~h}$, the reaction mixture was cooled in an ice bath. The crude mixture was filtered through a celite pad and concentrated in vacuo. The residue was analyzed by ${ }^{1} \mathrm{H}$ NMR spectroscopy. Yields of products were determined using $\mathrm{CH}_{2} \mathrm{Br}_{2}$ (49.5 mg, $0.28 \mathrm{mmol}$ ) as the internal standard. For each substrate the average of two reactions was obtained.<smiles>[R]c1cccc(Nc2ncccn2)c1</smiles><smiles>BrC1CCCCC1</smiles>
$\left[(\mathrm{DME}) \mathrm{NiCl}_{2}\right](5 \mathrm{~mol} \%)$

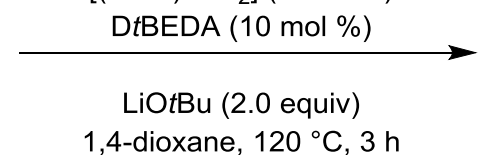
(1.0 equiv)

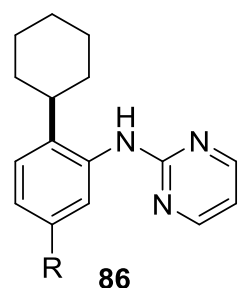

\begin{tabular}{|c|c|c|c|}
\hline $\mathbf{R}$ & $\mathbf{P}$ & $\boldsymbol{\sigma}_{\mathbf{p}}$ & $\log$ (ratio (R/H) \\
\hline OMe & 6 & -0.27 & -0.76 \\
\hline $\mathrm{Me}$ & 13 & -0.17 & -0.43 \\
\hline $\mathrm{H}$ & 35 & 0.00 & 0 \\
\hline $\mathrm{F}$ & 37 & 0.06 & 0.03 \\
\hline $\mathrm{Cl}$ & 24 & 0.23 & -0.16 \\
\hline $\mathrm{CF}_{3}$ & 76 & 0.54 & 0.34 \\
\hline
\end{tabular}

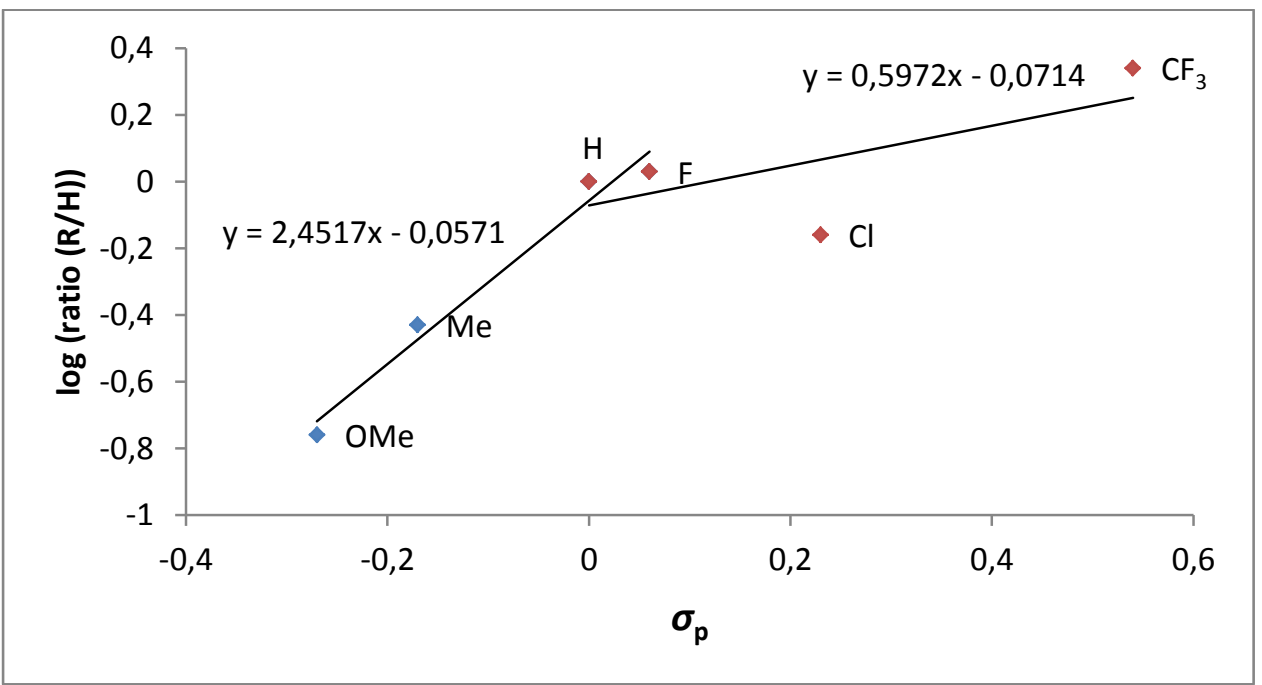




\subsubsection{Analytical Data for C-H Fluoroalkylation of $N$-(2-Pyrimidyl)anilines 69}

Synthesis of $N$-[2-Fluoro-6-(2,2,2-trifluoroethyl)phenyl]pyrimidin-2-amine (87a)<smiles>Fc1cccc(CC(F)(F)F)c1Nc1ncccn1</smiles>

The general procedure E1 was followed using 69a $(189 \mathrm{mg}, 1.0 \mathrm{mmol})$ and $146(489 \mathrm{mg}$, $3.0 \mathrm{mmol}$ ). After purification by column chromatography ( $n$-hexane/EtOAc 3:1), followed by GPC purification, 87a (147 mg, 54\%) was obtained as a white solid.

The general procedure E2 was followed using 69a (189 mg, $1.0 \mathrm{mmol}$ ) and 146 (489 mg, $3.0 \mathrm{mmol}$ ). After purification by column chromatography ( $n$-hexane/EtOAc 3:1), followed by GPC purification, 87a (188 mg, 69\%) was obtained as a white solid.

The general procedure E3 was followed using 69a (189 mg, $1.0 \mathrm{mmol})$ and $82(420 \mathrm{mg}$, $2.0 \mathrm{mmol}$ ). After purification by column chromatography ( $n$-hexane/EtOAc 3:1), followed by GPC purification, $87 a$ ( $218 \mathrm{mg}, 80 \%$ ) was obtained as a white solid.

M.p.: $105-106^{\circ} \mathrm{C}$

${ }^{1} \mathrm{H}$ NMR $\left(600 \mathrm{MHz}, \mathrm{CDCl}_{3}\right): \delta=8.35(\mathrm{~d}, J=4.8 \mathrm{~Hz}, 2 \mathrm{H}), 7.30(\mathrm{ddd}, J=8.3,7.8,5.4 \mathrm{~Hz}, 1 \mathrm{H}), 7.23$ (d, $J=7.8 \mathrm{~Hz}, 1 \mathrm{H}$ ), $7.17(\mathrm{ddd}, J=9.6,8.3,1.4 \mathrm{~Hz}, 1 \mathrm{H}), 6.88(\mathrm{~s}, 1 \mathrm{H}), 6.71(\mathrm{t}, J=4.8 \mathrm{~Hz}, 1 \mathrm{H}), 3.52$ (q, $J=10.7 \mathrm{~Hz}, 2 \mathrm{H}$ ).

${ }^{13} \mathrm{C}$ NMR $\left(125 \mathrm{MHz}, \mathrm{CDCl}_{3}\right): \delta=161.4\left(\mathrm{C}_{\mathrm{q}}\right), 159.0\left(\mathrm{C}_{\mathrm{q}}, \mathrm{d},{ }^{1} \mathrm{~J}_{\mathrm{C}-\mathrm{F}}=247.6 \mathrm{~Hz}\right), 158.3(\mathrm{CH}), 130.8\left(\mathrm{C}_{\mathrm{q}}\right.$ $\left.\mathrm{q},{ }^{3} J_{\mathrm{C}-\mathrm{F}}=2.7 \mathrm{~Hz}\right), 128.1\left(\mathrm{CH}, \mathrm{d},{ }^{3} J_{\mathrm{C}-\mathrm{F}}=7.4 \mathrm{~Hz}\right), 126.8\left(\mathrm{CH}, \mathrm{q},{ }^{3} J_{\mathrm{C}-\mathrm{F}}=2.7 \mathrm{~Hz}\right), 126.4\left(\mathrm{C}_{\mathrm{q}}, \mathrm{q},{ }^{2} J_{\mathrm{C}-\mathrm{F}}=\right.$ $13.0 \mathrm{~Hz}), 125.9\left(\mathrm{C}_{\mathrm{q}}, \mathrm{q},{ }^{1} \mathrm{~J}_{\mathrm{C}-\mathrm{F}}=277.1 \mathrm{~Hz}\right), 116.3\left(\mathrm{CH}, \mathrm{d},{ }^{2} \mathrm{~J}_{\mathrm{C}-\mathrm{F}}=20.9 \mathrm{~Hz}\right), 112.9(\mathrm{CH}), 36.1\left(\mathrm{CH}_{2}, \mathrm{qd}\right.$, $\left.{ }^{2,4} J_{C-F}=30.4,2.6 \mathrm{~Hz}\right)$.

${ }^{19}$ F NMR $\left(283 \mathrm{MHz}, \mathrm{CDCl}_{3}\right): \delta=-64.99(\mathrm{t}, J=10.7 \mathrm{~Hz}),-117.63(\mathrm{dd}, J=9.6,5.0 \mathrm{~Hz})$.

IR (neat): $\tilde{v}=3234,2963,2921,1576,1449,1407,1258,1096,787,638 \mathrm{~cm}^{-1}$.

MS (EI): $m / z$ (relative intensity) $271(12)\left[\mathrm{M}^{+}\right], 252$ (27), 232 (17), 201 (8), 188 (100), 182 (3).

HR-MS (EI): $\mathrm{m} / \mathrm{z}$ calcd for $\mathrm{C}_{12} \mathrm{H}_{9} \mathrm{~F}_{4} \mathrm{~N}_{3}\left[\mathrm{M}^{+}\right]$271.0733, found 271.0743 . 
Synthesis of $N$-[2-Methyl-6-(2,2,2-trifluoroethyl)phenyl]pyrimidin-2-amine (87b)<smiles>Cc1cccc(CC(F)(F)F)c1Nc1ncccn1</smiles>

The general procedure E1 was followed using 69b (185 mg, $1.0 \mathrm{mmol})$ and 146 (489 mg, $3.0 \mathrm{mmol}$ ). After purification by column chromatography ( $n$-hexane/EtOAc 3:1), followed by GPC purification, 87b (181 mg, 68\%) was obtained as a pale brown solid.

The general procedure E2 was followed using 69b (185 mg, $1.0 \mathrm{mmol})$ and 146 (489 mg, $3.0 \mathrm{mmol}$ ). After purification by column chromatography ( $n$-hexane/EtOAc 3:1), followed by GPC purification, 87b (184 mg, 69\%) was obtained as a pale brown solid.

The general procedure E3 was followed using 69b $(185 \mathrm{mg}, 1.0 \mathrm{mmol})$ and $82(420 \mathrm{mg}$, $2.0 \mathrm{mmol}$ ). After purification by column chromatography ( $n$-hexane/EtOAc 3:1), followed by GPC purification, 87b (190 mg, 71\%) was obtained as a pale brown solid.

M.p.: $104-105^{\circ} \mathrm{C}$

${ }^{1} \mathrm{H}$ NMR $\left(600 \mathrm{MHz}, \mathrm{CDCl}_{3}\right): \delta=8.32(\mathrm{t}, J=4.8 \mathrm{~Hz}, 2 \mathrm{H}), 7.31-7.27(\mathrm{~m}, 2 \mathrm{H}), 7.26-7.23(\mathrm{~m}, 1 \mathrm{H})$, $7.09(\mathrm{~s}, 1 \mathrm{H}), 6.63(\mathrm{t}, J=4.8 \mathrm{~Hz}, 1 \mathrm{H}), 3.45(\mathrm{q}, J=10.3 \mathrm{~Hz}, 2 \mathrm{H}), 2.24(\mathrm{~s}, 3 \mathrm{H})$.

${ }^{13} \mathrm{C}$ NMR $\left(125 \mathrm{MHz}, \mathrm{CDCl}_{3}\right): \delta=161.5\left(\mathrm{C}_{\mathrm{q}}\right), 158.5(\mathrm{CH}), 137.7\left(\mathrm{C}_{\mathrm{q}}\right), 136.4\left(\mathrm{C}_{\mathrm{q}}\right), 131.0(\mathrm{CH})$, $129.3(\mathrm{CH}), 129.1\left(\mathrm{C}_{\mathrm{q}}, \mathrm{q},{ }^{3} \mathrm{~J}_{\mathrm{C}-\mathrm{F}}=2.2 \mathrm{~Hz}\right), 127.6(\mathrm{CH}), 126.2\left(\mathrm{C}_{\mathrm{q}}, \mathrm{q},{ }^{1} \mathrm{~J}_{\mathrm{C}-\mathrm{F}}=277.6 \mathrm{~Hz}\right), 112.0(\mathrm{CH})$, $36.5\left(\mathrm{CH}_{2}, \mathrm{q},{ }^{2} \mathrm{~J}_{\mathrm{C}-\mathrm{F}}=29.4 \mathrm{~Hz}\right), 18.93\left(\mathrm{CH}_{3}\right)$.

${ }^{19}$ F NMR $\left(283 \mathrm{MHz}, \mathrm{CDCl}_{3}\right): \delta=-65.09(\mathrm{t}, J=10.3 \mathrm{~Hz})$.

IR (neat): $\tilde{v}=3193,2971,2921,1577,1446,1358,1258,1128,791,639 \mathrm{~cm}^{-1}$.

MS (EI): $m / z$ (relative intensity) 267 (34) [M+], 252 (38), 232 (18), 197 (7), 184 (100).

HR-MS (EI): $\mathrm{m} / \mathrm{z}$ calcd for $\mathrm{C}_{13} \mathrm{H}_{12} \mathrm{~F}_{3} \mathrm{~N}_{3}\left[\mathrm{M}^{+}\right]$267.0983, found 267.0993. 
<smiles>COc1cccc(CC(F)(F)F)c1Nc1ncccn1</smiles>

The general procedure E1 was followed using 69c $(201 \mathrm{mg}, 1.0 \mathrm{mmol})$ and $146(489 \mathrm{mg}$, $3.0 \mathrm{mmol}$ ). After purification by column chromatography ( $n$-hexane/EtOAc $3: 1$ ), followed by GPC purification, 87c (94 mg, 33\%) was obtained as a white solid.

The general procedure E2 was followed using 69c (201 mg, $1.0 \mathrm{mmol})$ and 146 (489 mg, $3.0 \mathrm{mmol}$ ). After purification by column chromatography ( $n$-hexane/EtOAc $3: 1$ ), followed by GPC purification, 87c (226 mg, 78\%) was obtained as a white solid.

The general procedure E3 was followed using 69c $(201 \mathrm{mg}, 1.0 \mathrm{mmol})$ and 82 (420 mg, $3.0 \mathrm{mmol}$ ). After purification by column chromatography ( $n$-hexane/EtOAc $3: 1$ ), followed by GPC purification, 87c (140 mg, 50\%) was obtained as a white solid.

M.p.: $118-119^{\circ} \mathrm{C}$

${ }^{1}$ H NMR $\left(600 \mathrm{MHz}, \mathrm{CDCl}_{3}\right): \delta=8.33(\mathrm{~d}, J=4.8 \mathrm{~Hz}, 2 \mathrm{H}), 7.29-7.26(\mathrm{~m}, 1 \mathrm{H}), 7.06(\mathrm{~d}, J=7.8 \mathrm{~Hz}$, $1 \mathrm{H}), 6.95(\mathrm{~d}, J=8.3 \mathrm{~Hz}, 1 \mathrm{H}), 6.71(\mathrm{~s}, 1 \mathrm{H}), 6.66(\mathrm{t}, J=4.8 \mathrm{~Hz}, 1 \mathrm{H}), 3.78(\mathrm{~s}, 3 \mathrm{H}), 3.49(\mathrm{q}, J=$ $11.0 \mathrm{~Hz}, 2 \mathrm{H})$.

${ }^{13} \mathrm{C}$ NMR $\left(125 \mathrm{MHz}, \mathrm{CDCl}_{3}\right): \delta=162.0\left(\mathrm{C}_{\mathrm{q}}\right), 158.3(\mathrm{CH}), 155.4\left(\mathrm{C}_{\mathrm{q}}\right), 140.5\left(\mathrm{C}_{\mathrm{q}}\right) 130.2\left(\mathrm{C}_{\mathrm{q}}, \mathrm{q},{ }^{3} \mathrm{~J}_{\mathrm{C}-\mathrm{F}}\right.$ $=2.6 \mathrm{~Hz}), 127.6(\mathrm{CH}), 126.2\left(\mathrm{C}_{\mathrm{q}}, \mathrm{q},{ }^{1} \mathrm{~J}_{\mathrm{C}-\mathrm{F}}=275.4 \mathrm{~Hz}\right), 122.8(\mathrm{CH}), 112.4(\mathrm{CH}), 111.2(\mathrm{CH}), 55.9$ $\left(\mathrm{CH}_{3}\right), 36.2\left(\mathrm{CH}_{2}, \mathrm{q},{ }^{2} \mathrm{~J}_{\mathrm{C}-\mathrm{F}}=29.9 \mathrm{~Hz}\right)$.

${ }^{19}$ F NMR $\left(283 \mathrm{MHz}, \mathrm{CDCl}_{3}\right): \delta=-64.60(\mathrm{t}, J=10.9 \mathrm{~Hz})$.

IR (neat): $\tilde{v}=3212,3009,2938,2841,1580,1450,1410,1262,1105,795 \mathrm{~cm}^{-1}$.

MS (EI): $m / z$ (relative intensity) $283(4)\left[\mathrm{M}^{+}\right], 260$ (52), 252 (100), 232 (54), 200 (32), 182 (25).

HR-MS (ESI): $\mathrm{m} / \mathrm{z}$ calcd for $\mathrm{C}_{13} \mathrm{H}_{13} \mathrm{~F}_{3} \mathrm{~N}_{3} \mathrm{O}\left[\mathrm{M}+\mathrm{H}^{+}\right]$284.1013, found 284.1007. 
<smiles>FC(F)(F)Cc1cccc(-c2ccccc2)c1Nc1ncccn1</smiles>

The general procedure E2 was followed using 69e $(247 \mathrm{mg}, 1.0 \mathrm{mmol})$ and 146 (489 mg, $3.0 \mathrm{mmol}$ ). After purification by column chromatography ( $n$-hexane/EtOAc 3:1), followed by GPC purification, 87 e (257 mg, 77\%) was obtained as a white solid.

The general procedure E3 was followed using 69e $(247 \mathrm{mg}, 1.0 \mathrm{mmol})$ and $82(420 \mathrm{mg}$, $2.0 \mathrm{mmol}$ ). After purification by column chromatography ( $n$-hexane/EtOAc 3:1), followed by GPC purification, 87 e (270 $\mathrm{mg}, 82 \%)$ was obtained as a white solid.

M.p.: $159-160^{\circ} \mathrm{C}$

${ }^{1} \mathbf{H}$ NMR $\left(600 \mathrm{MHz}, \mathrm{CDCl}_{3}\right): \delta=8.21(\mathrm{~d}, J=4.8 \mathrm{~Hz}, 2 \mathrm{H}), 7.49-7.47(\mathrm{~m}, 1 \mathrm{H}), 7.41-7.39(\mathrm{~m}$, $2 \mathrm{H}), 7.29-7.23(\mathrm{~m}, 5 \mathrm{H}), 6.78(\mathrm{~s}, 1 \mathrm{H}), 6.55(\mathrm{t}, J=4.8 \mathrm{~Hz}, 1 \mathrm{H}), 3.51(\mathrm{q}, J=10.9 \mathrm{~Hz}, 2 \mathrm{H})$.

${ }^{13} \mathrm{C}$ NMR $\left(125 \mathrm{MHz}, \mathrm{CDCl}_{3}\right): \delta=161.5\left(\mathrm{C}_{\mathrm{q}}\right), 158.2(\mathrm{CH}), 140.9\left(\mathrm{C}_{\mathrm{q}}\right), 139.4\left(\mathrm{C}_{\mathrm{q}}\right), 135.3\left(\mathrm{C}_{\mathrm{q}}\right), 130.9$ $(\mathrm{CH}), 130.6(\mathrm{CH}), 129.7\left(\mathrm{C}_{\mathrm{q}}, \mathrm{q},{ }^{3} \mathrm{~J}_{\mathrm{C}-\mathrm{F}}=2.8 \mathrm{~Hz}\right), 128.9(\mathrm{CH}), 128.2(\mathrm{CH}), 127.4(\mathrm{CH}), 127.4(\mathrm{CH})$, $126.2\left(\mathrm{C}_{\mathrm{q}}, \mathrm{q},{ }^{1} \mathrm{~J}_{\mathrm{C}-\mathrm{F}}=276.9 \mathrm{~Hz}\right), 112.0(\mathrm{CH}), 36.5\left(\mathrm{CH}_{2}, \mathrm{q},{ }^{2} J_{\mathrm{C}-\mathrm{F}}=27.8 \mathrm{~Hz}\right)$.

${ }^{19}$ F NMR $\left(283 \mathrm{MHz}, \mathrm{CDCl}_{3}\right): \delta=-64.62(\mathrm{t}, J=10.9 \mathrm{~Hz})$.

IR (neat): $\tilde{v}=3194,3026,2916,1578,1442,1410,1244,1109,1066,759 \mathrm{~cm}^{-1}$.

MS (EI): m/z (relative intensity) $329(23)\left[\mathrm{M}^{+}\right], 289$ (6), 259 (9), 246 (100), 232 (10), 182 (5).

HR-MS (EI): $\mathrm{m} / \mathrm{z}$ calcd for $\mathrm{C}_{18} \mathrm{H}_{14} \mathrm{~F}_{3} \mathrm{~N}_{3}\left[\mathrm{M}^{+}\right]$329.1140, found 329.1138 .

\section{Synthesis of $\mathrm{N}$-[5-Chloro-2-(2,2,2-trifluoroethyl)phenyl]pyrimidin-2-amine $(87 \mathrm{~m})$}<smiles>FC(F)(F)Cc1ccc(Cl)cc1Nc1ncccn1</smiles>

The general procedure E2 was followed using 69m (206 mg, $1.0 \mathrm{mmol})$ and 146 (489 mg, $3.0 \mathrm{mmol}$ ). After purification by column chromatography ( $n$-hexane/EtOAc 3:1), followed by GPC purification, $87 \mathrm{~m}$ (75 mg, 26\%) was obtained as a white solid. 
M.p.: $104-105^{\circ} \mathrm{C}$

${ }^{1} \mathbf{H}$ NMR $\left(600 \mathrm{MHz}, \mathrm{CDCl}_{3}\right): \delta=8.41(\mathrm{~d}, J=4.8 \mathrm{~Hz}, 2 \mathrm{H}), 7.89(\mathrm{~d}, J=2.2 \mathrm{~Hz}, 1 \mathrm{H}), 7.27(\mathrm{~d}, J=$ $8.3 \mathrm{~Hz}, 1 \mathrm{H}), 7.17(\mathrm{dd}, J=8.3,2.2 \mathrm{~Hz}, 1 \mathrm{H}), 7.01(\mathrm{~s}, 1 \mathrm{H}), 6.77(\mathrm{t}, J=4.8 \mathrm{~Hz}, 1 \mathrm{H}), 3.45(\mathrm{q}, J=$ $10.7 \mathrm{~Hz}, 2 \mathrm{H})$.

${ }^{13} \mathrm{C}$ NMR $\left(125 \mathrm{MHz}, \mathrm{CDCl}_{3}\right): \delta=160.5\left(\mathrm{C}_{\mathrm{q}}\right), 158.3(\mathrm{CH}), 139.2\left(\mathrm{C}_{\mathrm{q}}\right), 134.8\left(\mathrm{C}_{\mathrm{q}}\right), 132.9(\mathrm{CH})$, $125.9\left(\mathrm{C}_{\mathrm{q}}, \mathrm{q},{ }^{1} \mathrm{~J}_{\mathrm{C}-\mathrm{F}}=275.1 \mathrm{~Hz}\right), 125.3(\mathrm{CH}), 125.2(\mathrm{CH}), 121.8\left(\mathrm{C}_{\mathrm{q}}, \mathrm{q},{ }^{3} J_{\mathrm{C}-\mathrm{F}}=2.6 \mathrm{~Hz}\right), 113.4(\mathrm{CH})$, $36.0\left(\mathrm{CH}_{2}, \mathrm{q},{ }^{2} J_{\mathrm{C}-\mathrm{F}}=30.7 \mathrm{~Hz}\right)$.

${ }^{19}$ F NMR $\left(283 \mathrm{MHz}, \mathrm{CDCl}_{3}\right): \delta=-65.05(\mathrm{t}, J=10.7 \mathrm{~Hz})$.

IR (neat): $\tilde{v}=3237,3085,1571,1445,1357,1229,1122,1068,798,633 \mathrm{~cm}^{-1}$.

MS (EI): m/z (relative intensity) 287 (10) [M+], 266 (3), 247 (10), 217 (7), 204 (100), 182 (3).

HR-MS (EI): $\mathrm{m} / \mathrm{z}$ calcd for $\mathrm{C}_{12} \mathrm{H}_{9} \mathrm{ClF}_{3} \mathrm{~N}_{3}\left[\mathrm{M}^{+}\right]$287.0437, found 287.0442.

\section{Synthesis of $\mathrm{N}$-[5-Methyl-2-(2,2,2-trifluoroethyl)phenyl]pyrimidin-2-amine (87n)}<smiles>Cc1ccc(CC(F)(F)F)c(Nc2ncccn2)c1</smiles>

The general procedure E2 was followed using 69n (185 mg, $1.0 \mathrm{mmol}$ ) and 146 (489 mg, $3.0 \mathrm{mmol}$ ). After purification by column chromatography ( $n$-hexane/EtOAc 3:1), followed by GPC purification, $\mathbf{8 7 n}$ (85 mg, 32\%) was obtained as a white solid.

M.p.: $99-100^{\circ} \mathrm{C}$

${ }^{1} \mathbf{H}$ NMR $\left(600 \mathrm{MHz}, \mathrm{CDCl}_{3}\right): \delta=8.36(\mathrm{~d}, J=4.8 \mathrm{~Hz}, 2 \mathrm{H}), 7.46(\mathrm{~s}, 1 \mathrm{H}), 7.26(\mathrm{~d}, J=7.8 \mathrm{~Hz}, 1 \mathrm{H})$, $7.06-7.02(\mathrm{~m}, 2 \mathrm{H}), 6.69(\mathrm{t}, J=4.8 \mathrm{~Hz}, 1 \mathrm{H}), 3.44(\mathrm{q}, J=10.9 \mathrm{~Hz}, 2 \mathrm{H}), 2.37(\mathrm{~s}, 3 \mathrm{H})$.

${ }^{13} \mathrm{C}$ NMR $\left(125 \mathrm{MHz}, \mathrm{CDCl}_{3}\right): \delta=161.2\left(\mathrm{C}_{\mathrm{q}}\right), 158.3(\mathrm{CH}), 139.2\left(\mathrm{C}_{\mathrm{q}}\right), 137.7\left(\mathrm{C}_{\mathrm{q}}\right), 131.7(\mathrm{CH})$, $126.9(\mathrm{CH}), 126.9(\mathrm{CH}), 126.2\left(\mathrm{C}_{\mathrm{q}}, \mathrm{q},{ }^{1} \mathrm{~J}_{\mathrm{C}-\mathrm{F}}=278.7 \mathrm{~Hz}\right), 122.1\left(\mathrm{C}_{\mathrm{q}}, \mathrm{q},{ }^{3} J_{\mathrm{C}-\mathrm{F}}=2.7 \mathrm{~Hz}\right), 112.5(\mathrm{CH})$, $36.0\left(\mathrm{CH}_{2}, \mathrm{q},{ }^{2} J_{\mathrm{C}-\mathrm{F}}=27.9 \mathrm{~Hz}\right), 21.5\left(\mathrm{CH}_{3}\right)$.

${ }^{19}$ F NMR $\left(283 \mathrm{MHz}, \mathrm{CDCl}_{3}\right): \delta=-65.19(\mathrm{t}, J=10.9 \mathrm{~Hz})$.

IR (neat): $\tilde{v}=3239,3010,1576,1527,1448,1411,1244,1136,1070,789 \mathrm{~cm}^{-1}$. 
MS (EI): m/z (relative intensity) 267 (7) [M+], 246 (2), 227 (4), 197 (4), 184 (100), 148 (2).

HR-MS (EI): $\mathrm{m} / \mathrm{z}$ calcd for $\mathrm{C}_{13} \mathrm{H}_{12} \mathrm{~F}_{3} \mathrm{~N}_{3}\left[\mathrm{M}^{+}\right]$267.0983, found 267.0984 .

Synthesis of $N$-[5-Methoxy-2-(2,2,2-trifluoroethyl)phenyl]pyrimidin-2-amine (870)<smiles>COc1ccc(CC(F)(F)F)c(Nc2ncccn2)c1</smiles>

The general procedure E2 was followed using $690(201 \mathrm{mg}, 1.0 \mathrm{mmol})$ and $146(489 \mathrm{mg}$, $3.0 \mathrm{mmol}$ ). After purification by column chromatography ( $n$-hexane/EtOAc 3:1), followed by GPC purification, $\mathbf{8 7 0}$ (85 mg, 30\%) was obtained as a brown solid.

M.p.: $88-89^{\circ} \mathrm{C}$

${ }^{1} \mathbf{H}$ NMR $\left(600 \mathrm{MHz}, \mathrm{CDCl}_{3}\right): \delta=8.41(\mathrm{~d}, J=4.8 \mathrm{~Hz}, 2 \mathrm{H}), 7.38(\mathrm{~d}, J=2.7 \mathrm{~Hz}, 1 \mathrm{H}), 7.25(\mathrm{~d}, J=$ $7.2 \mathrm{~Hz}, 1 \mathrm{H}), 6.89(\mathrm{~s}, 1 \mathrm{H}), 6.79-6.70(\mathrm{~m}, 2 \mathrm{H}), 3.82(\mathrm{~s}, 3 \mathrm{H}), 3.41(\mathrm{q}, J=10.9 \mathrm{~Hz}, 2 \mathrm{H})$.

${ }^{13}$ C NMR (125 MHz, CDCl $): \delta=161.1(\mathrm{Cq}), 160.0(\mathrm{Cq}), 158.2(\mathrm{CH}), 139.0(\mathrm{Cq}), 132.6(\mathrm{CH})$, $126.2\left(\mathrm{C}_{\mathrm{q}}, \mathrm{q},{ }^{1} \mathrm{~J}_{\mathrm{C}-\mathrm{F}}=277.1 \mathrm{~Hz}\right), 116.2(\mathrm{Cq}), 112.8(\mathrm{CH}), 111.3(\mathrm{CH}), 111.2(\mathrm{CH}), 55.5\left(\mathrm{CH}_{3}\right), 35.7$ $\left(\mathrm{CH}_{2}, \mathrm{q},{ }^{2} J_{\mathrm{C}-\mathrm{F}}=29.3 \mathrm{~Hz}\right)$.

${ }^{19}$ F NMR $\left(283 \mathrm{MHz}, \mathrm{CDCl}_{3}\right): \delta=-65.42(\mathrm{t}, J=10.8 \mathrm{~Hz})$.

IR (neat): $\tilde{v}=3227,3095,3009,1575,1443,1401,1257,1119,1059,798 \mathrm{~cm}^{-1}$.

MS (ESI): $m / z$ (relative intensity) 306 (22), 284 (100) [M+H'], 257 (2), 227 (4), 159 (2).

HR-MS (ESI): $\mathrm{m} / \mathrm{z}$ calcd for $\mathrm{C}_{13} \mathrm{H}_{13} \mathrm{~F}_{3} \mathrm{~N}_{3} \mathrm{O}\left[\mathrm{M}+\mathrm{H}^{+}\right]$284.1010, found 284.1006.

Synthesis of $\mathrm{N}$-[2-(2,2,2-trifluoroethyl)phenyl]pyrimidin-2-amine $(87 \mathrm{~h})$ and $\mathrm{N}-[2,6-$ bis(2,2,2-trifluoroethyl)phenyl]pyrimidin-2-amine $\left(87 \mathrm{~h}^{\prime}\right)$<smiles>FC(F)(F)Cc1ccccc1Nc1ncccn1</smiles> 
The general procedure E2 was followed using 69h $(171 \mathrm{mg}, 1.0 \mathrm{mmol})$ and $146(489 \mathrm{mg}$, $3.0 \mathrm{mmol}$ ). After purification by column chromatography ( $n$-hexane/EtOAc 3:1), followed by GPC purification, $\mathbf{8 7 h}$ (138 mg, 55\%) and 87h' (54 mg, 16\%) were obtained as white solids.

$87 \mathrm{~h}$

M.p.: $123-124{ }^{\circ} \mathrm{C}$

${ }^{1} \mathrm{H}$ NMR $\left(600 \mathrm{MHz}, \mathrm{CDCl}_{3}\right): \delta=8.38(\mathrm{~d}, J=4.8 \mathrm{~Hz}, 2 \mathrm{H}), 7.69(\mathrm{~d}, J=8.1 \mathrm{~Hz}, 1 \mathrm{H}), 7.42-7.35(\mathrm{~m}$, $2 \mathrm{H}), 7.22(\mathrm{dd}, J=7.6,7.6,1.1 \mathrm{~Hz}, 1 \mathrm{H}), 7.05(\mathrm{~s}, 1 \mathrm{H}), 6.71(\mathrm{t}, J=4.8 \mathrm{~Hz}, 1 \mathrm{H}), 3.49(\mathrm{q}, J=10.8 \mathrm{~Hz}$, $2 \mathrm{H})$.

${ }^{13} \mathrm{C}$ NMR (125 MHz, $\left.\mathrm{CDCl}_{3}\right): \delta=161.1\left(\mathrm{C}_{\mathrm{q}}\right), 158.3(\mathrm{CH}), 138.0\left(\mathrm{C}_{\mathrm{q}}\right), 132.0(\mathrm{CH}), 129.2(\mathrm{CH})$, $126.2(\mathrm{CH}), 126.1\left(\mathrm{C}_{\mathrm{q}}, \mathrm{q},{ }^{1} \mathrm{~J}_{\mathrm{C}-\mathrm{F}}=276.3 \mathrm{~Hz}\right), 125.8(\mathrm{CH}), 124.8\left(\mathrm{C}_{\mathrm{q}}, \mathrm{q},{ }^{3} \mathrm{~J}_{\mathrm{C}-\mathrm{F}}=2.3 \mathrm{~Hz}\right), 112.8(\mathrm{CH})$, $36.3\left(\mathrm{CH}_{2}, \mathrm{q},{ }^{2} J_{\mathrm{C}-\mathrm{F}}=29.6 \mathrm{~Hz}\right)$.

${ }^{19}$ F NMR $\left(283 \mathrm{MHz}, \mathrm{CDCl}_{3}\right): \delta=-65.02(\mathrm{t}, J=10.8 \mathrm{~Hz})$.

IR (neat): $\tilde{v}=3251,1580,1518,1444,1356,1245,1135,1068,756,653 \mathrm{~cm}^{-1}$.

MS (EI): $m / z$ (relative intensity) 253 (8) [M+], 232 (3), 213 (5), 183 (4), 170 (100), 168 (3).

HR-MS (EI): $\mathrm{m} / \mathrm{z}$ calcd for $\mathrm{C}_{12} \mathrm{H}_{10} \mathrm{~F}_{3} \mathrm{~N}_{3}\left[\mathrm{M}^{+}\right]$253.0827, found 253.0826 .

\section{$87 h^{\prime}$}

M.p.: $142-143^{\circ} \mathrm{C}$

${ }^{1} \mathrm{H}$ NMR $\left(600 \mathrm{MHz}, \mathrm{CDCl}_{3}\right): \delta=8.32(\mathrm{~d}, J=4.7 \mathrm{~Hz}, 2 \mathrm{H}), 7.46(\mathrm{~d}, J=7.7 \mathrm{~Hz}, 2 \mathrm{H}), 7.38(\mathrm{t}, J=$ $7.7 \mathrm{~Hz}, 1 \mathrm{H}), 6.93(\mathrm{~s}, 1 \mathrm{H}), 6.68(\mathrm{t}, J=4.7 \mathrm{~Hz}, 1 \mathrm{H}), 3.42(\mathrm{br} \mathrm{s}, 4 \mathrm{H})$.

${ }^{13} \mathrm{C} \mathrm{NMR}\left(125 \mathrm{MHz}, \mathrm{CDCl}_{3}\right): \delta=161.3\left(\mathrm{C}_{\mathrm{q}}\right), 158.7(\mathrm{CH}), 137.3\left(\mathrm{C}_{\mathrm{q}}\right), 131.9(\mathrm{CH}), 130.5\left(\mathrm{C}_{\mathrm{q}}, \mathrm{q},{ }^{3} \mathrm{~J}_{\mathrm{C}}\right.$ $F=2.5 \mathrm{~Hz}), 128.1(\mathrm{CH}), 125.9\left(\mathrm{C}_{\mathrm{q}}, \mathrm{q},{ }^{1} \mathrm{~J}_{\mathrm{C}-\mathrm{F}}=277.1 \mathrm{~Hz}\right), 112.5(\mathrm{CH}), 36.6\left(\mathrm{CH}_{2}, \mathrm{q},{ }^{2} J_{\mathrm{C}-\mathrm{F}}=30.5 \mathrm{~Hz}\right)$.

${ }^{19}$ F NMR $\left(283 \mathrm{MHz}, \mathrm{CDCl}_{3}\right): \delta=-65.01(\mathrm{t}, J=10.7 \mathrm{~Hz})$.

IR (neat): $\tilde{v}=3206,2927,1580,1449,1354,1252,1128,1062,777,600 \mathrm{~cm}^{-1}$.

MS (EI): m/z (relative intensity) 335 (13) $\left[\mathrm{M}^{+}\right], 295$ (4), 275 (6), 265 (6), 252 (100), 232 (44), $226(4), 182(8)$.

HR-MS (EI): $\mathrm{m} / \mathrm{z}$ calcd for $\mathrm{C}_{14} \mathrm{H}_{11} \mathrm{~F}_{6} \mathrm{~N}_{3}\left[\mathrm{M}^{+}\right]$335.0857, found 335.0851. 
Synthesis of $\mathrm{N}$-[4-Fluoro-2-(2,2,2-trifluoroethyl)phenyl]pyrimidin-2-amine (87k)<smiles>Fc1ccc(Nc2ncccn2)c(CC(F)(F)F)c1</smiles>

The general procedure E2 was followed using 69k (189 mg, $1.0 \mathrm{mmol})$ and $146(489 \mathrm{mg}$, $3.0 \mathrm{mmol}$ ). After purification by column chromatography ( $n$-hexane/EtOAc $3: 1$ ), followed by GPC purification, $\mathbf{8 7 k}$ (43 mg, 16\%) was obtained as a white solid.

M.p.: $101-102{ }^{\circ} \mathrm{C}$

${ }^{1} \mathbf{H}$ NMR $\left(600 \mathrm{MHz}, \mathrm{CDCl}_{3}\right): \delta=8.35(\mathrm{~d}, J=4.8 \mathrm{~Hz}, 2 \mathrm{H}), 7.56(\mathrm{dd}, J=8.5,5.3 \mathrm{~Hz}, 1 \mathrm{H}), 7.12-$ $7.08(\mathrm{~m}, 2 \mathrm{H}), 6.89(\mathrm{~s}, 1 \mathrm{H}), 6.71(\mathrm{t}, J=4.8 \mathrm{~Hz}, 1 \mathrm{H}), 3.46(\mathrm{q}, J=10.7 \mathrm{~Hz}, 2 \mathrm{H})$.

${ }^{13} \mathrm{C}$ NMR $\left(125 \mathrm{MHz}, \mathrm{CDCl}_{3}\right): \delta=161.3\left(\mathrm{C}_{\mathrm{q}}\right), 160.2\left(\mathrm{C}_{\mathrm{q}}, \mathrm{d},{ }^{1} J_{\mathrm{C}-\mathrm{F}}=245.7 \mathrm{~Hz}\right), 158.3(\mathrm{CH}), 134.0\left(\mathrm{C}_{\mathrm{q}}\right.$ d, $\left.{ }^{4} J_{C-F}=2.9 \mathrm{~Hz}\right), 128.8\left(\mathrm{CH}, \mathrm{d},{ }^{3} J_{\mathrm{C}-\mathrm{F}}=9.2 \mathrm{~Hz}\right), 127.8\left(\mathrm{C}_{\mathrm{q}}, \mathrm{dq},{ }^{3,3} J_{\mathrm{C}-\mathrm{F}}=7.8,2.6 \mathrm{~Hz}\right), 125.9\left(\mathrm{C}_{\mathrm{q}}, \mathrm{q}\right.$, $\left.{ }^{1} J_{\mathrm{C}-\mathrm{F}}=277.1 \mathrm{~Hz}\right), 118.3\left(\mathrm{CH}, \mathrm{d},{ }^{2} J_{\mathrm{C}-\mathrm{F}}=24.0 \mathrm{~Hz}\right), 116.3\left(\mathrm{CH}, \mathrm{d},{ }^{2} J_{\mathrm{C}-\mathrm{F}}=21.3 \mathrm{~Hz}\right), 112.8(\mathrm{CH}), 36.3$ $\left(\mathrm{CH}_{2}, \mathrm{qd},{ }^{2,4} J_{\mathrm{C}-\mathrm{F}}=30.3,1.3 \mathrm{~Hz}\right)$.

${ }^{19} \mathrm{~F}$ NMR $\left(283 \mathrm{MHz}, \mathrm{CDCl}_{3}\right): \delta=-64.98(\mathrm{t}, J=10.7 \mathrm{~Hz}),-115.71(\mathrm{ddd}, J=8.4,8.4,5.3 \mathrm{~Hz})$.

IR (neat): $\tilde{v}=3206,2928,1581,1412,1255,1209,1129,1070,802,541 \mathrm{~cm}^{-1}$.

MS (EI): $m / z$ (relative intensity) $271(13)\left[\mathrm{M}^{+}\right], 250$ (4), 231 (9), 201 (5), 188 (100), 178 (2), $100(2)$.

HR-MS (EI): $\mathrm{m} / \mathrm{z}$ calcd for $\mathrm{C}_{12} \mathrm{H}_{9} \mathrm{~F}_{4} \mathrm{~N}_{3}\left[\mathrm{M}^{+}\right] 271.0733$, found 271.0735 .

Synthesis of $\mathrm{N}$-[4-Methyl-2-(2,2,2-trifluoroethyl)phenyl]pyrimidin-2-amine (87I) and $\mathrm{N}$-[4Methyl-2,6-bis(2,2,2-trifluoroethyl)phenyl]pyrimidin-2-amine (87l')<smiles>Cc1ccc(Nc2ncccn2)c(CC(F)(F)F)c1CC(F)(F)F</smiles>

The general procedure E2 was followed using 69l (185 mg, $1.0 \mathrm{mmol})$ and $146(326 \mathrm{mg}$, $2.0 \mathrm{mmol}$ ). After purification by column chromatography ( $n$-hexane/EtOAc 3:1), followed by GPC purification, 87l (114 mg, 43\%) and 87l' (19 mg, 6\%) were obtained as white solids.

871: 
M.p.: $114-115^{\circ} \mathrm{C}$

${ }^{1} \mathbf{H}$ NMR $\left(600 \mathrm{MHz}, \mathrm{CDCl}_{3}\right): \delta=8.34(\mathrm{~d}, J=4.8 \mathrm{~Hz}, 2 \mathrm{H}), 7.47(\mathrm{~d}, J=8.0 \mathrm{~Hz}, 1 \mathrm{H}), 7.21-7.18(\mathrm{~m}$, $2 \mathrm{H}), 6.99(\mathrm{~s}, 1 \mathrm{H}), 6.67(\mathrm{t}, J=4.8 \mathrm{~Hz}, 1 \mathrm{H}), 3.44(\mathrm{q}, J=10.9 \mathrm{~Hz}, 2 \mathrm{H}), 2.36(\mathrm{~s}, 3 \mathrm{H})$.

${ }^{13} \mathrm{C}$ NMR $\left(125 \mathrm{MHz}, \mathrm{CDCl}_{3}\right): \delta=161.5\left(\mathrm{C}_{\mathrm{q}}\right), 158.3(\mathrm{CH}), 136.0\left(\mathrm{C}_{\mathrm{q}}\right), 135.3\left(\mathrm{C}_{\mathrm{q}}\right), 132.4(\mathrm{CH})$, $130.0(\mathrm{CH}), 126.9(\mathrm{CH}), 126.2\left(\mathrm{C}_{\mathrm{q}}, \mathrm{q},{ }^{1} \mathrm{~J}_{\mathrm{C}-\mathrm{F}}=276.3 \mathrm{~Hz}\right), 125.4\left(\mathrm{C}_{\mathrm{q}}, \mathrm{q},{ }^{3} \mathrm{~J}_{\mathrm{C}-\mathrm{F}}=2.5 \mathrm{~Hz}\right), 112.4(\mathrm{CH})$, $36.2\left(\mathrm{CH}_{2}, \mathrm{q},{ }^{2} \mathrm{~J}_{\mathrm{C}-\mathrm{F}}=29.8 \mathrm{~Hz}\right), 21.2\left(\mathrm{CH}_{3}\right)$.

${ }^{19}$ F NMR $\left(283 \mathrm{MHz}, \mathrm{CDCl}_{3}\right): \delta=-65.03(\mathrm{t}, J=10.9 \mathrm{~Hz})$.

IR (neat): $\tilde{v}=3292,1581,1513,1445,1399,1245,1124,1069,795,608 \mathrm{~cm}^{-1}$.

MS (EI): m/z (relative intensity) 267 (9) [M+], 246 (3), 227 (4), 197 (3), 184 (100), 148 (2).

HR-MS (EI): $\mathrm{m} / \mathrm{z}$ calcd for $\mathrm{C}_{13} \mathrm{H}_{12} \mathrm{~F}_{3} \mathrm{~N}_{3}\left[\mathrm{M}^{+}\right]$267.0983, found 267.0980 .

87l':

M.p.: $126-127^{\circ} \mathrm{C}$

${ }^{1} \mathrm{H}$ NMR $\left(600 \mathrm{MHz}, \mathrm{CDCl}_{3}\right): \delta=8.30(\mathrm{~d}, J=4.8 \mathrm{~Hz}, 2 \mathrm{H}), 7.26(\mathrm{~s}, 2 \mathrm{H}), 7.10(\mathrm{~s}, 1 \mathrm{H}), 6.65(\mathrm{t}, J=$ $4.8 \mathrm{~Hz}, 1 \mathrm{H}), 3.37$ (br s, 4H), $2.39(\mathrm{~s}, 3 \mathrm{H})$.

${ }^{13} \mathrm{C}$ NMR $\left(125 \mathrm{MHz}, \mathrm{CDCl}_{3}\right): \delta=161.4\left(\mathrm{C}_{\mathrm{q}}\right), 158.7(\mathrm{CH}), 138.1\left(\mathrm{C}_{\mathrm{q}}\right), 134.6\left(\mathrm{C}_{\mathrm{q}}\right), 132.6(\mathrm{CH})$, $130.1\left(\mathrm{C}_{\mathrm{q}}, \mathrm{q},{ }^{3} J_{\mathrm{C}-\mathrm{F}}=1.9 \mathrm{~Hz}\right), 126.0\left(\mathrm{C}_{\mathrm{q}}, \mathrm{q},{ }^{1} J_{\mathrm{C}-\mathrm{F}}=276.5 \mathrm{~Hz}\right), 112.4(\mathrm{CH}), 36.5\left(\mathrm{CH}_{2}, \mathrm{q},{ }^{2} J_{\mathrm{C}-\mathrm{F}}=\right.$ $29.9 \mathrm{~Hz}), 21.3\left(\mathrm{CH}_{3}\right)$.

${ }^{19} \mathrm{~F} \operatorname{NMR}\left(283 \mathrm{MHz}, \mathrm{CDCl}_{3}\right): \delta=-64.99(\mathrm{t}, J=10.8 \mathrm{~Hz})$.

IR (neat): $\tilde{v}=3223,2922,1585,1517,1256,1234,1139,1079,801,639 \mathrm{~cm}^{-1}$.

MS (EI): m/z (relative intensity) 349 (5) [M+], 309 (2), 279 (2), 266 (100), 246 (11), 196 (3).

HR-MS (EI): $\mathrm{m} / \mathrm{z}$ calcd for $\mathrm{C}_{15} \mathrm{H}_{13} \mathrm{~F}_{6} \mathrm{~N}_{3}\left[\mathrm{M}^{+}\right]$349.1014, found 349.1019.

Synthesis of $N$-[2-(2,2,2-trifluoroethyl)naphthalen-1-yl]pyrimidin-2-amine (87g)<smiles>FC(F)(F)Cc1ccc2ccccc2c1Nc1ncccn1</smiles> 
The general procedure E2 was followed using $69 \mathrm{~g}(221 \mathrm{mg}, 1.0 \mathrm{mmol})$ and $146(489 \mathrm{mg}$, $3.0 \mathrm{mmol}$ ). After purification by column chromatography ( $n$-hexane/EtOAc 3:1), followed by GPC purification, $\mathbf{8 7 g}$ (135 mg, 45\%) was obtained as a white solid.

M.p.: $149-150^{\circ} \mathrm{C}$

${ }^{1} \mathrm{H}$ NMR $\left(600 \mathrm{MHz}, \mathrm{CDCl}_{3}\right): \delta=8.26(\mathrm{~d}, J=4.8 \mathrm{~Hz}, 2 \mathrm{H}), 8.03(\mathrm{~d}, J=8.4 \mathrm{~Hz}, 1 \mathrm{H}), 7.93(\mathrm{~s}, 1 \mathrm{H})$, $7.90(\mathrm{~d}, J=7.6 \mathrm{~Hz}, 1 \mathrm{H}), 7.88(\mathrm{~d}, J=8.5 \mathrm{~Hz}, 1 \mathrm{H}), 7.57(\mathrm{~d}, J=8.5 \mathrm{~Hz}, 1 \mathrm{H}), 7.55-7.48(\mathrm{~m}, 2 \mathrm{H})$, $6.61(\mathrm{t}, J=4.8 \mathrm{~Hz}, 1 \mathrm{H}), 3.66(\mathrm{~s}, 2 \mathrm{H})$.

${ }^{13} \mathrm{C}$ NMR $\left(125 \mathrm{MHz}, \mathrm{CDCl}_{3}\right): \delta=162.3\left(\mathrm{C}_{\mathrm{q}}\right), 158.5(\mathrm{CH}), 134.4\left(\mathrm{C}_{\mathrm{q}}\right), 134.1\left(\mathrm{C}_{\mathrm{q}}\right), 131.7\left(\mathrm{C}_{\mathrm{q}}\right), 128.4$ $(\mathrm{CH}), 128.2(\mathrm{CH}), 128.1(\mathrm{CH}), 127.0(\mathrm{CH}), 126.7\left(\mathrm{C}_{\mathrm{q}}, \mathrm{q}^{3}{ }^{3} \mathrm{~J}_{\mathrm{C}-\mathrm{F}}=2.2 \mathrm{~Hz}\right), 126.6(\mathrm{CH}), 126.3\left(\mathrm{C}_{\mathrm{q}}, \mathrm{q}\right.$, $\left.{ }^{1} J_{C-F}=277.1 \mathrm{~Hz}\right), 123.6(\mathrm{CH}), 112.1(\mathrm{CH}), 36.7\left(\mathrm{CH}_{2}, \mathrm{q},{ }^{2} J_{\mathrm{C}-\mathrm{F}}=30.2 \mathrm{~Hz}\right)$.

${ }^{19}$ F NMR $\left(283 \mathrm{MHz}, \mathrm{CDCl}_{3}\right): \delta=-64.59(\mathrm{t}, J=10.8 \mathrm{~Hz})$.

IR (neat): $\tilde{v}=3206,3008,2929,1589,1448,1265,1140,1064,812,516 \mathrm{~cm}^{-1}$.

MS (EI): $m / z$ (relative intensity) 303 (17) [M+], 282 (2), 263 (9), 232 (5), 220 (100), 192 (2).

HR-MS (EI): $\mathrm{m} / \mathrm{z}$ calcd for $\mathrm{C}_{16} \mathrm{H}_{12} \mathrm{~F}_{3} \mathrm{~N}_{3}\left[\mathrm{M}^{+}\right]$303.0983, found 303.0974 .

\section{Synthesis of 1-[(Difluoromethyl)sulfonyl]-N-(2-fluorophenyl)pyrimidin-2(1H)-imine (157a)}<smiles>O=S(O)n1cccnc1=Nc1ccccc1F</smiles>

The general procedure E2 was followed using 69a (57 mg, $0.3 \mathrm{mmol}$ ) and Langlois' reagent (94 mg, $0.6 \mathrm{mmol}$ ). After purification by column chromatography ( $n$-hexane/EtOAc 85:18), 157a (4 mg, 4\%) was obtained as a yellow solid.

M.p.: $130-132^{\circ} \mathrm{C}$

${ }^{1} \mathrm{H}$ NMR (300 MHz, $\left.\mathrm{CDCl}_{3}\right): \delta=8.20(\mathrm{dd}, J=3.6,2.5 \mathrm{~Hz}, 1 \mathrm{H}), 7.70(\mathrm{t}, J=60.2 \mathrm{~Hz}, 1 \mathrm{H}), 7.56$ (dd, $J=7.2,2.5 \mathrm{~Hz}, 1 \mathrm{H}), 7.12-6.92(\mathrm{~m}, 4 \mathrm{H}), 6.01(\mathrm{dd}, J=7.2,3.6 \mathrm{~Hz}, 1 \mathrm{H})$.

${ }^{13} \mathrm{C}$ NMR $\left(125 \mathrm{MHz}, \mathrm{CDCl}_{3}\right): \delta=163.7(\mathrm{CH}), 154.7\left(\mathrm{C}_{\mathrm{q}}, \mathrm{d},{ }^{1} \mathrm{~J}_{\mathrm{C}-\mathrm{F}}=244.4 \mathrm{~Hz}\right), 147.4\left(\mathrm{C}_{\mathrm{q}}\right), 138.1$ $\left(\mathrm{CH}, \mathrm{t},{ }^{4} J_{\mathrm{C}-\mathrm{F}}=2.6 \mathrm{~Hz}\right), 135.3\left(\mathrm{C}_{\mathrm{q}}, \mathrm{d},{ }^{2} J_{\mathrm{C}-\mathrm{F}}=11.5 \mathrm{~Hz}\right), 124.6\left(\mathrm{CH}, \mathrm{d},{ }^{4} J_{\mathrm{C}-\mathrm{F}}=2.4 \mathrm{~Hz}\right), 124.1(\mathrm{CH}, \mathrm{d}$, $\left.{ }^{3} J_{C-F}=3.8 \mathrm{~Hz}\right), 124.0\left(\mathrm{CH}, \mathrm{d},{ }^{3} J_{\mathrm{C}-\mathrm{F}}=7.4 \mathrm{~Hz}\right), 115.8\left(\mathrm{CH}, \mathrm{d},{ }^{4} J_{\mathrm{C}-\mathrm{F}}=20.5 \mathrm{~Hz}\right), 108.6\left(\mathrm{CH}, \mathrm{t},{ }^{1} J_{\mathrm{C}-\mathrm{F}}=\right.$ $255.6 \mathrm{~Hz}), 102.4(\mathrm{CH})$.

${ }^{19}$ F NMR $\left(283 \mathrm{MHz}, \mathrm{CDCl}_{3}\right): \delta=-104.02(\mathrm{~d}, J=60.2 \mathrm{~Hz}),-124.96--125.11(\mathrm{~m})$. 
IR (neat): $\tilde{v}=3503,3094,1678,1568,1499,1411,1310,1075,746,693 \mathrm{~cm}^{-1}$.

MS (EI): m/z (relative intensity) 217 (3), 188 (40), 170 (100), 136 (5), 109 (4), 85 (11).

HR-MS (EI): $\mathrm{m} / \mathrm{z}$ calcd for $\mathrm{C}_{10} \mathrm{H}_{9} \mathrm{FN}_{3}\left[\mathrm{M}+2 \mathrm{H}-\mathrm{SO}_{2} \mathrm{CHF}_{2}^{+}\right]$190.0781, found 190.0776 .

\section{Mechanistic studies}

$H / D$ exchange experiments with $[D]_{5}-69 \mathrm{~h}$ as the substrate:

Following the general procedure E2 [D $]_{5}-69 \mathrm{~h}(176 \mathrm{mg}, 1.0 \mathrm{mmol})$ was reacted with 146 (245 $\mathrm{mg}, 1.5 \mathrm{mmol}$ ). After $3 \mathrm{~h}$, the reaction was cooled to $0{ }^{\circ} \mathrm{C}$, filtered through a silica pad and concentrated in vacuo. Purification by GPC yielded $69 \mathrm{~h}(85 \mathrm{mg}, 48 \%)$ and $87 \mathrm{~h}$ (99 mg, 39\%). $\mathbf{8 7 h}$ was isolated as a mixture with a benzylated side-product from reaction with PhMe and yields were calculated from ${ }^{1} \mathrm{H}$ NMR ratio.

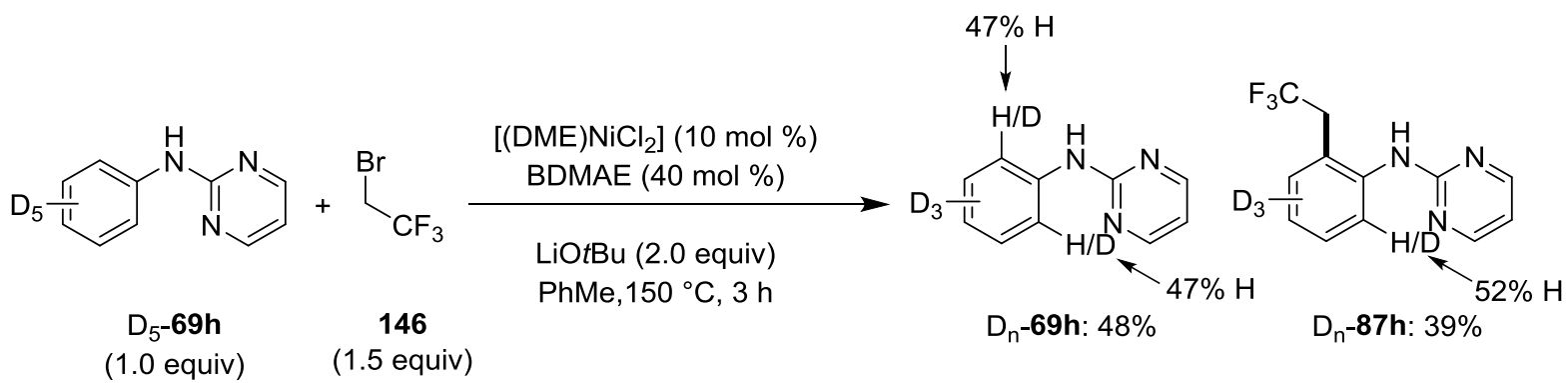



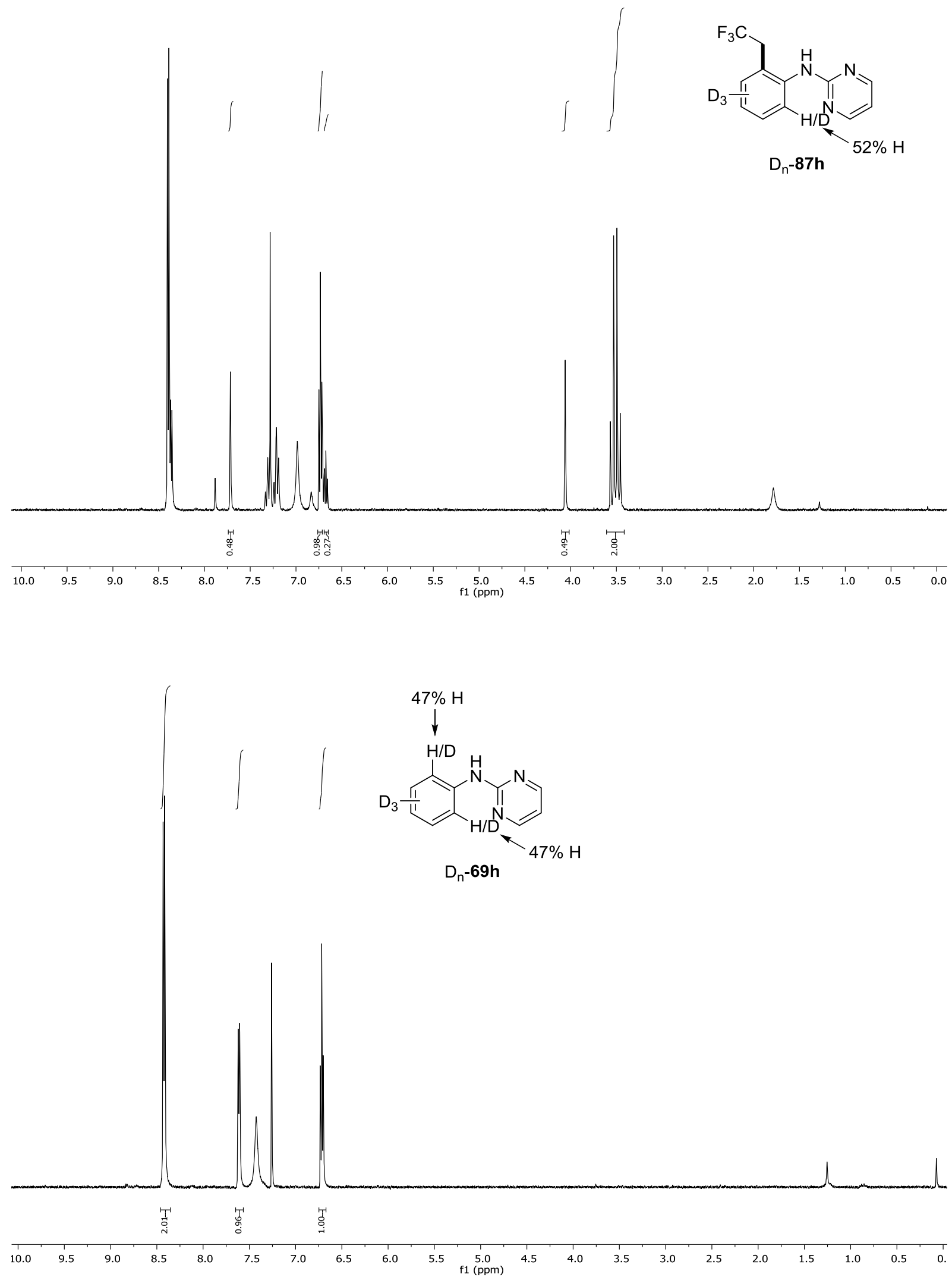
Intermolecular KIE Experiment between $69 \mathrm{~h}$ and $\left[D_{5}\right]-69 \mathrm{~h}$<smiles>[SbH3]c1ccc(Nc2ncccn2)cc1</smiles>

( 0.5 equiv each)

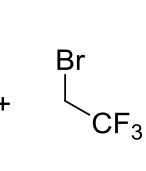

146

(1.5 equiv)

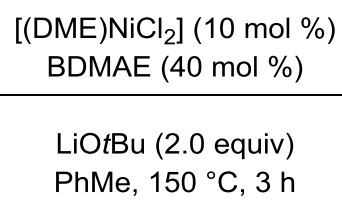

$\mathrm{k}_{\mathrm{H}} / \mathrm{k}_{\mathrm{D}}=1.1$<smiles>[2H]c1ccc(Nc2ncccn2)c(CC(F)(F)F)c1</smiles>

$D_{n}-87 h: 33 \%$

69h (86 mg, $0.5 \mathrm{mmol}),\left[\mathrm{D}_{5}\right]-69 \mathrm{~h}(88 \mathrm{mg}, 0.5 \mathrm{mmol}),\left[(\mathrm{DME}) \mathrm{NiCl}_{2}\right](22 \mathrm{mg}, 10 \mathrm{~mol} \%)$ and LiOtBu (160 mg, $2.0 \mathrm{mmol}$ ) were placed in a $25 \mathrm{~mL}$ sealed tube. The tube was evacuated and purged with Ar three times. BDMAE (76 $\mu \mathrm{L}, 40 \mathrm{~mol} \%$ ), trifluoroethylbromide 146 (245 mg, $1.5 \mathrm{mmol})$ and $\mathrm{PhMe}(2.0 \mathrm{~mL})$ were added, and the mixture was stirred at $150{ }^{\circ} \mathrm{C}$ for $3 \mathrm{~h}$. At ambient temperature, $\mathrm{CH}_{2} \mathrm{Cl}_{2}(2.0 \mathrm{~mL})$ was added and concentrated under reduced pressure. Purification of the crude reaction mixture by flash column chromatography and GPC yielded 69h (78 mg, 45\%) and $87 \mathrm{~h}$ ( $84 \mathrm{mg}, 33 \%$ ) as white solids.

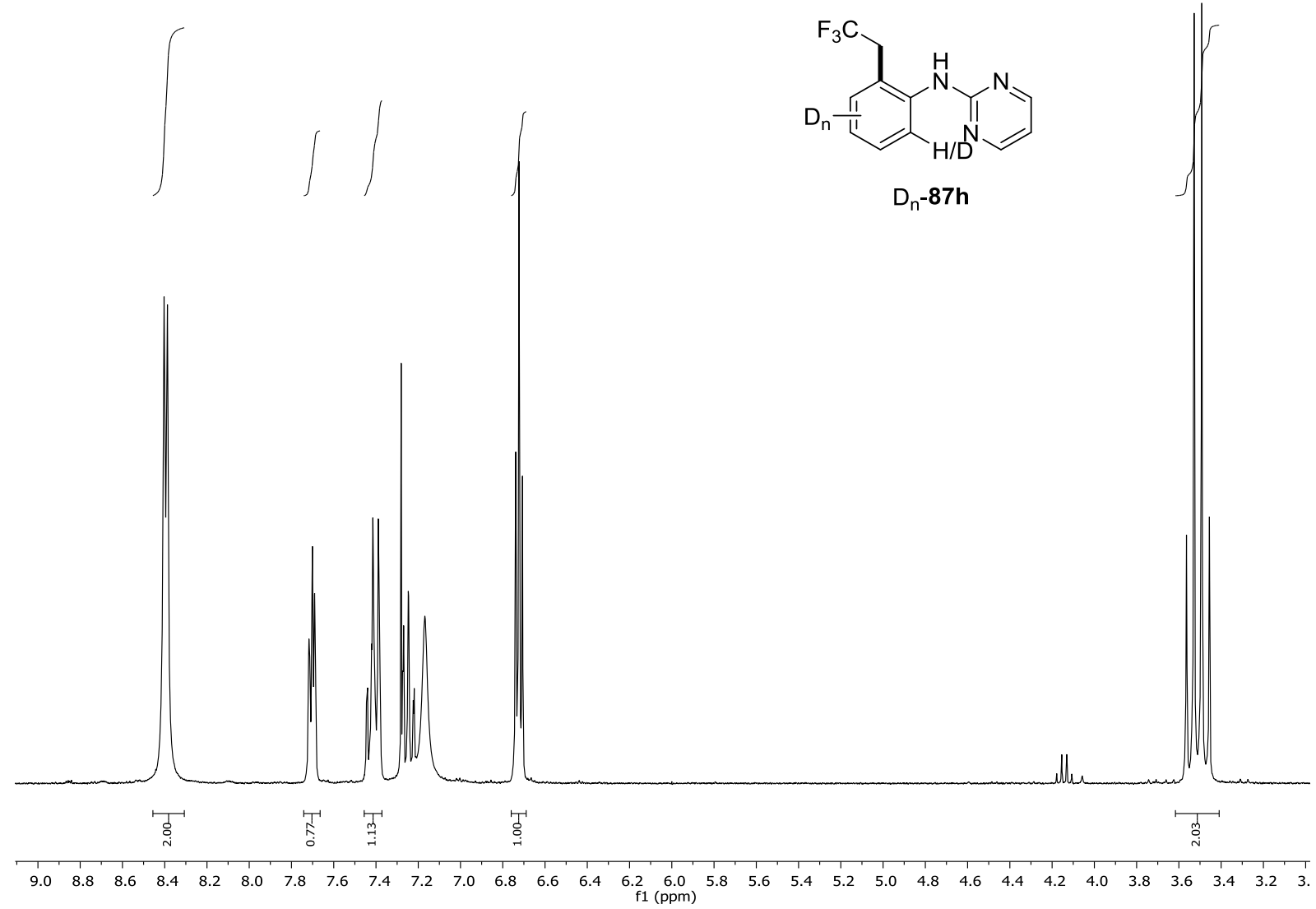




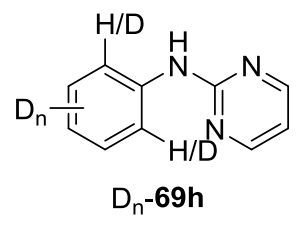
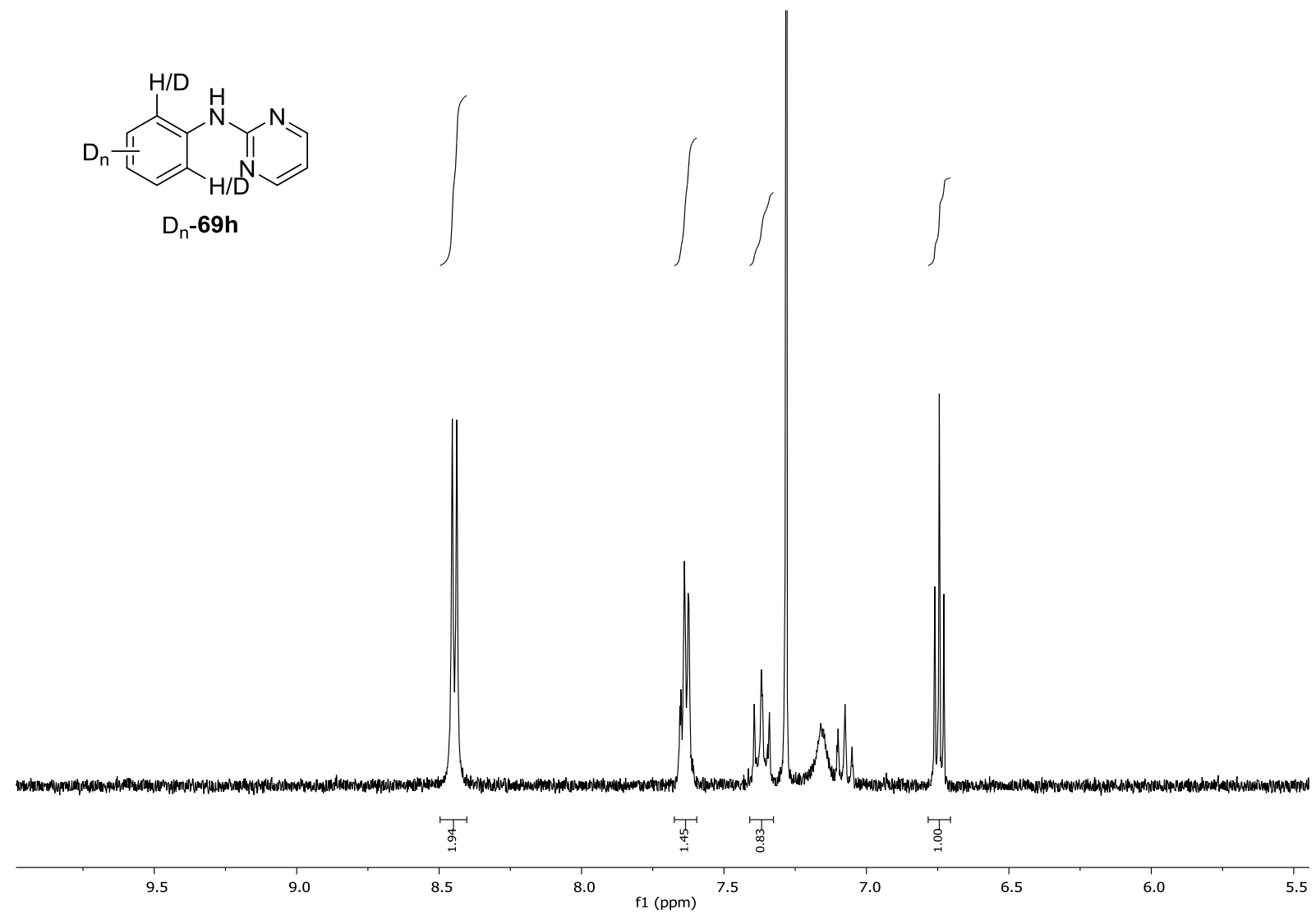

\section{Reaction with TEMPO}<smiles>Fc1ccccc1Nc1ncccn1</smiles>

$69 a$ (1.0 equiv)

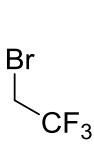

146 (3.0 equiv)
$\left[(\mathrm{DME}) \mathrm{NiCl}_{2}\right](10 \mathrm{~mol} \%)$ $\operatorname{BDMAE}(40 \mathrm{~mol} \%)$

TEMPO (1.0 equiv) LiOtBu (2.0 equiv) $\mathrm{PhMe}, 150^{\circ} \mathrm{C}, 16 \mathrm{~h}$<smiles>Fc1cccc(CC(F)(F)F)c1Nc1ncccn1</smiles>

87a: $0 \%$

$\mathrm{N}$-(2-Fluorophenyl)pyrimidin-2-amine $\quad$ (69a) $\quad(95 \mathrm{mg}, 0.5 \mathrm{mmol}), \quad$ [(DME) $\left.\mathrm{NiCl}_{2}\right] \quad(11 \mathrm{mg}$, $10 \mathrm{~mol} \%)$, TEMPO (78 mg, $0.5 \mathrm{mmol})$ and LiOtBu ( $80 \mathrm{mg}, 1.0 \mathrm{mmol})$ were placed in a $25 \mathrm{~mL}$ Schlenk tube. The tube was evacuated and purged with Ar three times. BDMAE $(38 \mu \mathrm{L}$, $40 \mathrm{~mol} \%)$, trifluoroethyl bromide (146) $(245 \mathrm{mg}, 1.5 \mathrm{mmol})$ and PhMe $(1.5 \mathrm{~mL})$ were then added, and the mixture was stirred at $150{ }^{\circ} \mathrm{C}$ for $16 \mathrm{~h}$. After cooling to ambient temperature, $\mathrm{CH}_{2} \mathrm{Cl}_{2}(2.0 \mathrm{~mL})$ was added. No conversion was observed through ${ }^{19} \mathrm{~F}$ NMR analysis of the crude reaction mixture. 
Intermolecular Competition Experiment between 69k and 69l

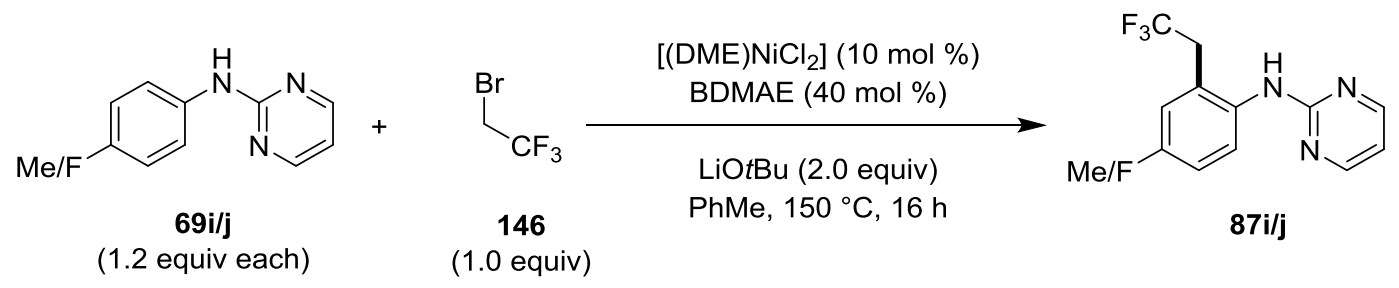

69k (223 mg, $1.2 \mathrm{mmol}), 69 \mathrm{l}$ (227 mg, $1.2 \mathrm{mmol})$, [(DME) NiCl ${ }_{2}$ (22 mg, $10 \mathrm{~mol} \%$ ) and LiOtBu (160 mg, $2.0 \mathrm{mmol}$ ) were placed in a $25 \mathrm{~mL}$ sealed tube. The tube was evacuated and purged with Ar three times. BDMAE (76 $\mu \mathrm{L}, 40 \mathrm{~mol} \%)$, trifluoroethylbromide (146) (163 mg, $1.0 \mathrm{mmol}$ ) and $\mathrm{PhMe}(2.0 \mathrm{~mL})$ were then added, and the mixture was stirred at $150{ }^{\circ} \mathrm{C}$ for $16 \mathrm{~h}$. At ambient temperature, $\mathrm{CH}_{2} \mathrm{Cl}_{2}(2.0 \mathrm{~mL})$ was added, and the reaction mixture was concentrated under reduced pressure. Analysis of the crude reaction mixture by ${ }^{19} \mathrm{~F} \mathrm{NMR}$ with $29 \mu \mathrm{LC}_{6} \mathrm{~F}_{6}$ as internal standard gave $3 \%$ of $87 \mathrm{I}$ and $1 \%$ of $\mathbf{8 7 k}$. 


\section{List of Abbreviations}

\begin{tabular}{|c|c|}
\hline$\left[\mathrm{M}^{+}\right]$ & Molecular ion peak \\
\hline Ac & acyl \\
\hline Ad & adamantyl \\
\hline Alk & alkyl \\
\hline $\operatorname{Ar}$ & aryl \\
\hline aq. & aqueous \\
\hline $\mathrm{BDC}$ & 1,4-benzenedicarboxylate \\
\hline BDMAE & bis(2-dimethylaminoethyl)ether \\
\hline BINOL & 1,1'-binaphthol \\
\hline $\mathrm{Bn}$ & benzyl \\
\hline$n \mathrm{Bu}$ & n-butyl \\
\hline br s & broad singlet \\
\hline$t \mathrm{Bu}$ & tert-butyl \\
\hline calc. & calculated \\
\hline $\operatorname{cod}$ & 1,5-cyclooctadiene \\
\hline $\mathrm{Cp}$ & cyclopentadienyl \\
\hline $\mathrm{Cp} *$ & 1,2,3,4,5-pentamethylcyclopentadienyl \\
\hline CPME & cyclopentyl methyl ether \\
\hline$\delta$ & chemical shift \\
\hline d & doublet \\
\hline DABCO & 1,4-diazabicyclo[2.2.2]octane \\
\hline DFT & density functional theory \\
\hline DIPP & 2,6-di-iso-propyl-phenyl \\
\hline DME & dimethoxyethane \\
\hline dppbz & 1,2-bis(diphenylphosphino)benzene \\
\hline dppf & $1,1^{\prime}$-bis(diphenylphosphino)ferrocene \\
\hline DtBEDA & $N^{\prime}, N^{\prime \prime}$-di-tert-Butylethane-1,2-diamine \\
\hline ee & enantiomeric excess \\
\hline EI & electron ionization \\
\hline ESI & electronspray ionization \\
\hline Et & ethyl \\
\hline et al & et alia \\
\hline equiv & equivalents \\
\hline g & gramm \\
\hline $\mathrm{h}$ & hours \\
\hline hept & heptet \\
\hline HR & high resolution \\
\hline $\mathrm{Hz}$ & Hertz \\
\hline IES & internal electrophilic substitution \\
\hline IR & infrared (spectroscopy) \\
\hline J & coupling constant \\
\hline L & ligand \\
\hline LDL-C & low-density lipoprotein - cholesterol \\
\hline
\end{tabular}




\begin{tabular}{|c|c|}
\hline M & metal \\
\hline $\mathrm{m}$ & multiplet \\
\hline Me & methyl \\
\hline 2-Me-THF & 2-Methyltetrahydrofuran \\
\hline $\mathrm{mg}$ & milligramm \\
\hline $\mathrm{mL}$ & milliliter \\
\hline $\mathrm{mmol}$ & millimol \\
\hline MEM & methoxy ethoxyl \\
\hline M.p. & melting point \\
\hline Mes & mesityl \\
\hline MS & mass spectrometry \\
\hline MTHP & tetrahydro-3-methyl-2H-pyran \\
\hline $\mathrm{m} / \mathrm{z}$ & mass-to-charge ratio \\
\hline n. d. & not determined \\
\hline $\mathrm{NHC}$ & $N$-heterocyclic carbene \\
\hline NMR & nuclear magnetic resonance \\
\hline $\mathrm{Ph}$ & phenyl \\
\hline PhthN & phthalimidyl \\
\hline $\operatorname{Pr}$ & propyl \\
\hline 2-py & 2-pyridyl \\
\hline 2-pym & 2-pyrimidyl \\
\hline Q & 8-quinolyl \\
\hline $\mathrm{R}$ & rest \\
\hline RRMS & relapsing-remitting multiple sclerosis \\
\hline s & singlet \\
\hline SEM & [2-(trimethylsilyl)ethoxy]methyl acetal \\
\hline SET & single electron transfer \\
\hline $\mathrm{t}$ & triplet \\
\hline $\mathrm{T}$ & temperature \\
\hline THF & tetrahydrofuran \\
\hline TM & transition metal \\
\hline TMEDA & $N, N, N^{\prime}, N^{\prime}$-tetramethylethane-1,2-diamine \\
\hline TMP & 2,2,6,6-tetramethylpiperidine \\
\hline Tf & triflate \\
\hline Ts & tosyl \\
\hline q & quartet \\
\hline UV & ultraviolet \\
\hline$x$ & (pseudo)halide \\
\hline
\end{tabular}




\section{Acknowledgements}

All my thanks and gratitude to:

Prof. Dr. Lutz Ackermann, for the opportunity to do research on interesting topics, the quality of supervision and his readiness for discussion about the chemistry.

Prof. Dr. Konrad Koszinowski for kindly agreeing to be the second supervisor, as well as the second referee for my work.

Prof. Dr. Claudia Höbartner, Prof. Dr. Sven Schneider, Dr. Franziska Thomas and Dr. Shoubik Das for kindly agreeing to be part of my thesis committee.

Everyone, who helped to proofread and correct my thesis, Dr. David J. Burns, Dr. Vladislav Kotek, Dr. Melanie Lorion, Michaela Bauer, Svenja Warratz, Nicolas Sauermann, Thomas Müller and Alexander Bechtoldt.

The staff of our group. Gabi for her help with all matters administrative and organisational. Stefan for his help with all computer issues and support for all equipment-related incidents. Karsten for his support and advise in laboratory matters.

My former labmates, especially Dr. Vaibhav Mehta, Dr. Jie (Jack) Li, Darko Santrac, Dr. Weifeng Song, especially for putting up with my choice of music.

All current and former members of the research group of Prof. Dr. Ackermann for the great working atmosphere. Especially all members and students, who cooperated on projects, helped with substrates or interestings discussions.

Ralf Gerke for his great support in the practical courses.

The NMR ans Mass Analytical Departments for all measurements, especially urgent, last minute ones. Particular thanks to Mr. Reinhard Machinek and Dr. Michael John for their willingness for extensive discussion of any spectra.

All my friends, especially everyone at my previous university in Munich, for being a continued source of fun, silliness and interesting ventures.

My parents, for their immense support during not just my educational path but all stages of my life, without which none of all this would have been possible. 


\section{Curriculum Vitae}

\section{Personal Details:}

Date of birth: 04.02.1986

Place of birth: Schwandorf

Nationality: German

\section{Education:}

01/2012 - present PhD studies under the supervision of Prof. Dr. Lutz Ackermann, Institute of Organic and Biomolecular Chemistry, Georg-AugustUniversity, Göttingen: "Nickel-Catalyzed Secondary Alkylations and Fluoroalkylations via C-H Activation."

12/2010 - 06/2011 Master thesis in organic chemistry in the group of Jr.-Prof. Dr. Stefan Kirsch, University of Technology Munich: "Development of transitionmetal-catalysed cyclisation-migration and cyclisationadditions domino reactions of keto-, ester- and amide-alkynyl derivatives"

$11 / 2009-02 / 2010$ Research internship in organic chemistry in the group of Prof. Dr. Mark Lautens, Lash Miller Chemical Laboratories, University of Toronto: "Rhodium(I)-catalysed domino transformation of o-alkynyl phenols to 2,3-disubstituted benzofurans"

03/2009-06/2011 Graduate studies (M. Sc.) in chemistry at the Department of Chemistry and Biochemistry, Faculty of Chemistry and Pharmacy, LudwigMaximilians-University Munich, Grade: 1.43 (Very Good)

06/2008 - 10/2008 Bachelor thesis in organic chemistry in the group of Prof. Dr. Thomas Carell: "Synthesis of the natural tRNA-modifications Wybutosine and Lysidine"

10/2005-11/2008 Undergraduate studies (B. Sc.) in chemistry and biochemistry at the Department of Chemistry and Biochemistry, Faculty of Chemistry and Pharmacy, Ludwig-Maximilians-University Munich, Grade: 2.18 (Good)

09/1996-07/2005 Grammar School: Regental Gymnasium, Nittenau, A Levels: 2.5

09/1992 - 07/1996 Primary School: Volksschule Wald, Wald 
Teaching Experience:

10/2012 - 09/2014 Teaching Assistant for "Catalysis Practical Course" and seminar for the lectures "Introduction to Catalysis Chemistry" and "Modern Advances in Catalysis"

04/2008-02/2009 Tutor for undergraduate students at Ludwig-Maximilians-University, Munich

Publications:

[4] Ruan, Z.; Lackner, S.; Ackermann, L. "A General Strategy for Nickel-Catalyzed C-H Alkylation of Anilines" Angew. Chem. Int. Ed. 2016, 55, 3153-3157.

[3] Song, W.; Lackner, S.; Ackermann, L. "Nickel-Catalyzed C-H Alkylations: Direct Secondary Alkylations and Trifluoroethylations of Arenes" Angew. Chem. Int. Ed. 2014, 53, 2477-2480.

[2] Boyer, A.; Isono, N.; Lackner, S.; Lautens, M. "Domino rhodium(I)-catalysed reactions for the efficient synthesis of substituted benzofurans and indoles" Tetrahedron 2010, $66,6468-6482$.

[1] Tegel, M.; Hummel, F.; Lackner, S.; Schellenberg, I.; Poettgen, R.; Johrendt, D. „The layered Iron arsenides oxides $\mathrm{Sr}_{2} \mathrm{CrO}_{3} \mathrm{FeAs}$ and $\mathrm{Ba}_{2} \mathrm{ScO}_{3} \mathrm{FeAs}$ " Z. Anorg. Allg. Chem. 2009, 635, 2242-2248.

Conferences, Oral Presentations:

$12 / 2014 \quad 10^{\text {th }}$ J-NOST Conference, IIT Madras, Chennai, India

\section{Conferences, Poster Presentations:}

07/2015 $\quad 7^{\text {th }}$ Göttinger Chemieforum, Göttingen

10/2014 NiKaS 2014, Göttingen

09/2014 Orchem 2014, Weimar

Extracurricular Activities and Memberships:

02/2013 - present Student Member of the GDCh 
8 Curriculum Vitae

08/2011-present Member of the Tierschutzverein München e.V. (Society for the prevention of cruelty to animals Munich)

06/2006-03/2011 Member of the Students' Council of Chemistry at the LudwigMaximilians-University, Munich

Languages:

German (Native)

English (Fluent)

Japanese (Basic) 